\title{
Groundwater Availability Within the Salton Sea Basin
}

Final Report

Andrew Tompson

zafer Demir

Jean Moran

Denise Mason

Jeff Wagoner

Stefan Kollet

Kayyum Mansoor

and

Peter McKereghan

Lawrence Livermore National Laboratory January 29, 2008 


\section{Disclaimer}

This document was prepared as an account of work sponsored by an agency of the United States government. Neither the United States government nor Lawrence Livermore National Security, LLC, nor any of their employees makes any warranty, expressed or implied, or assumes any legal liability or responsibility for the accuracy, completeness, or usefulness of any information, apparatus, product, or process disclosed, or represents that its use would not infringe privately owned rights. Reference herein to any specific commercial product, process, or service by trade name, trademark, manufacturer, or otherwise does not necessarily constitute or imply its endorsement, recommendation, or favoring by the United States government or Lawrence Livermore National Security, LLC. The views and opinions of authors expressed herein do not necessarily state or reflect those of the United States government or Lawrence Livermore National Security, LLC, and shall not be used for advertising or product endorsement purposes.

\section{Auspices Statement}

This work performed under the auspices of the U.S. Department of Energy by Lawrence Livermore National Laboratory under Contract DE-AC52-07NA27344. 


\section{Groundwater Availability Within the Salton Sea Basin}

Final Report

LLNL-TR-400426

\section{Authors:}

Andrew Tompson

Zafer Demir

Jean Moran

Denise Mason

Jeff Wagoner

Stefan Kollet

Kayyum Mansoor

Peter McKereghan

January 29, 2008 



\section{Table of Contents}

Executive Summary ........................................................................... 1

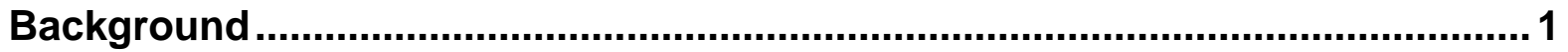

Groundwater Availability in the Basin ........................................................ 2

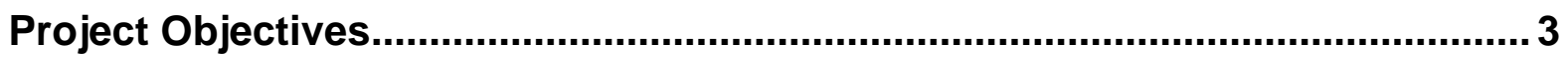

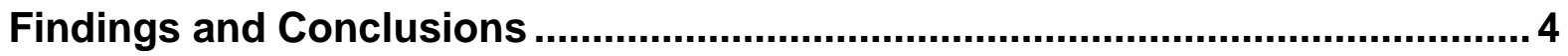

Additional Reccomendations......................................................................... 5

Section 1: Introduction ....................................................................6

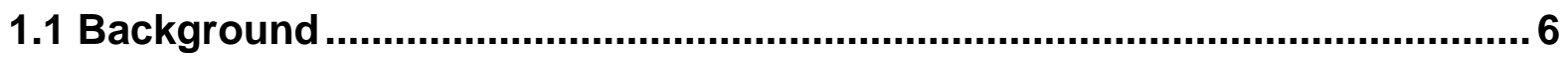

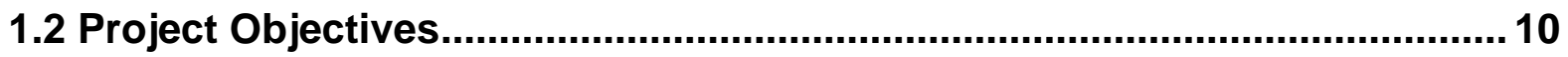

1.3 Report Organization .................................................................................... 11

Section 2: Physical Setting and Groundwater Occurrence ................12

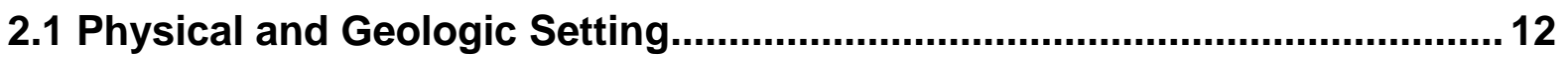

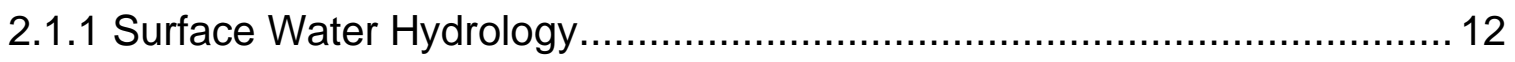

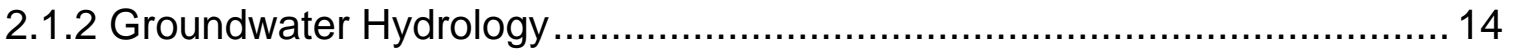

2.1.3 Tectonic and Geothermal Activity ...................................................... 15

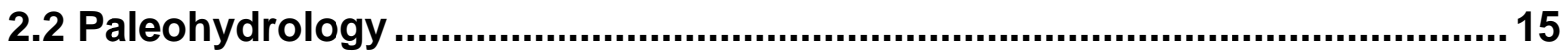

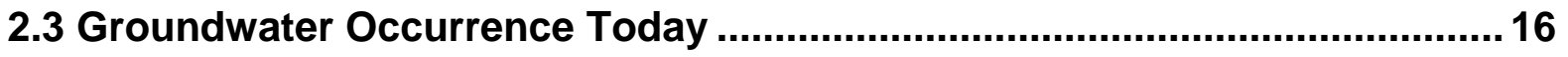

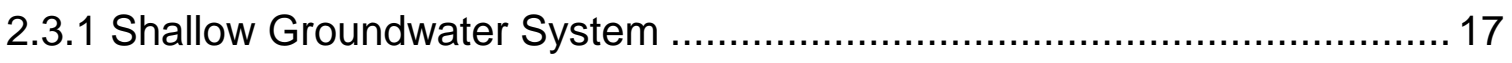

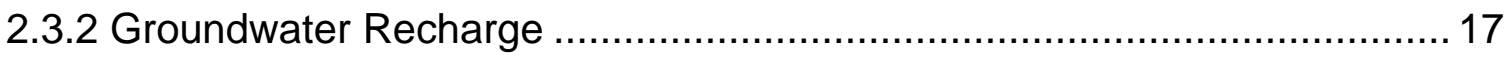

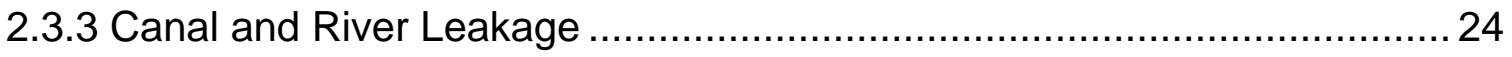

2.3.4 Natural Groundwater Discharges ................................................... 26

2.3.5 Deeper Groundwater System ..................................................... 26

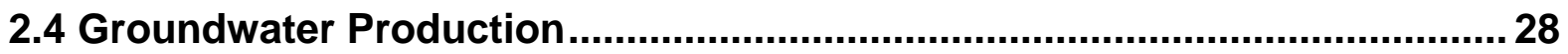

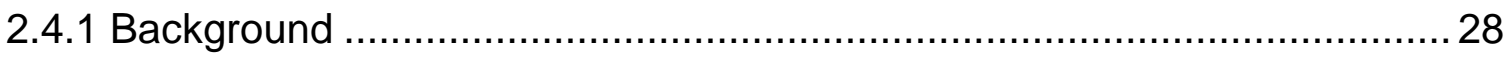

2.4.2 New Groundwater Production from the Shallow System ....................... 28

2.4.3 New Groundwater Production from the Deeper System ......................... 30

2.4.4 Wells, production data, and related aquifer characterization information .. 30

Section 3: Phase I Database and GIS Model Development...................33

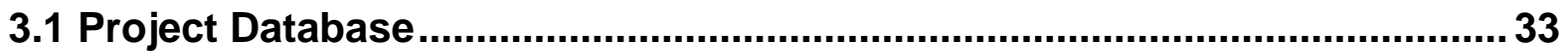


3.1.1 Literature Reference Database and Library ........................................ 33

3.1.2 Salton Sea Water Resources Database ............................................... 35

3.2 Project Website Development.................................................................... 40

Section 4: Phase I Database and GIS Products .................................42

Section 5: Concepts for Phase II Activities ........................................55

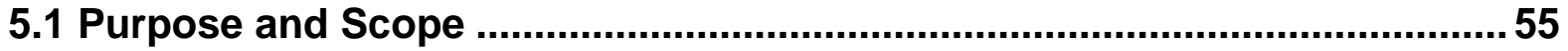

5.2 Overview of Potential Phase II Topics ......................................................... 55

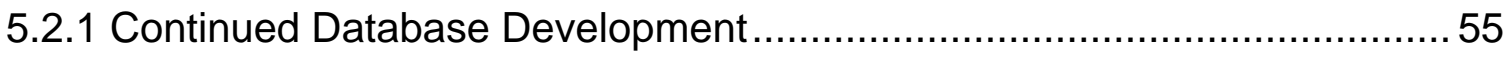

5.2.2 Refinement of Basin Conceptual Model ............................................. 56

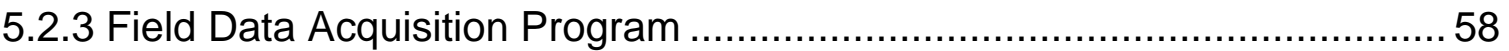

5.2.4 Modeling Assessment of Groundwater Availability ............................... 58

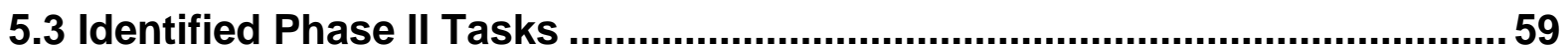

5.3.1 Groundwater Age and Recharge Source Assessment in the East Mesa... 59

5.3.2 Groundwater Model Development in the Imperial Valley Area ................. 60

Section 6: Phase II Groundwater Sampling and Isotopic Analyses in the East Mesa Area ..................................................................................61 61

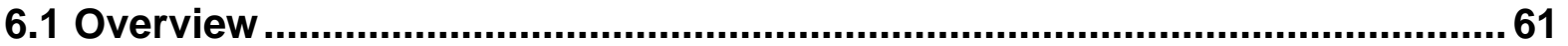

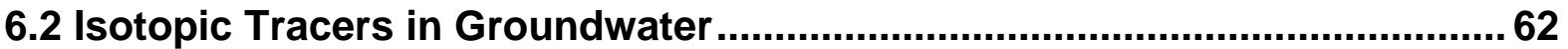

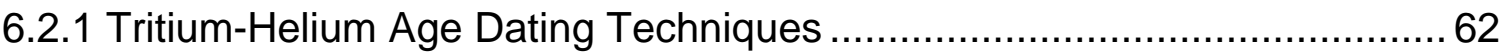

6.2.2 Stable Isotopes as Tracers of Recharge Source and Evaporation ............ 63

6.2.3 Other Tracers used for Groundwater Dating and Source Identification ..... 69

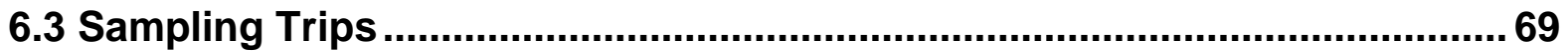

6.3 Sampling Results and Interpretation ......................................................... 74

6.4 Future Sampling Opportunities ................................................................... 78

Section 7: Phase II Groundwater Model Development in the Imperial

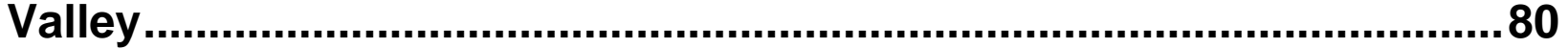

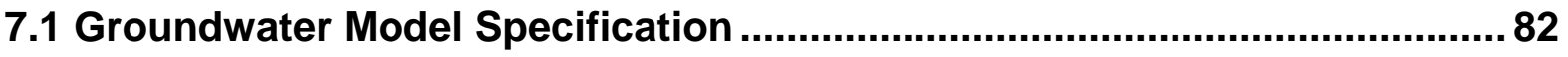

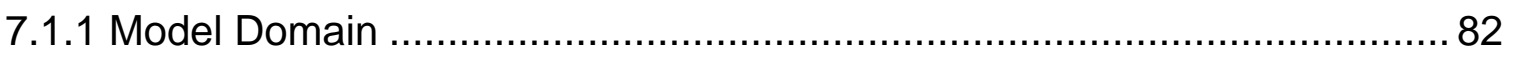

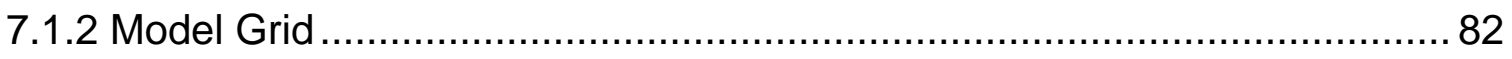

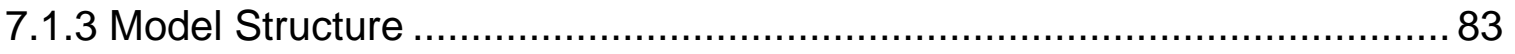

7.1.4 Regional Groundwater Elevation Map ............................................... 86 


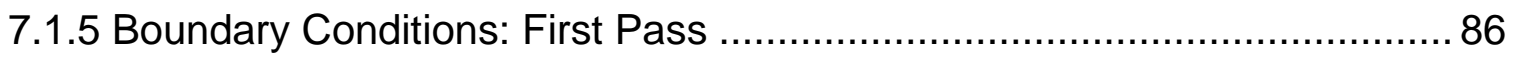

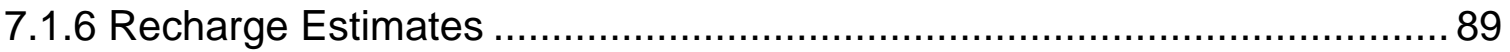

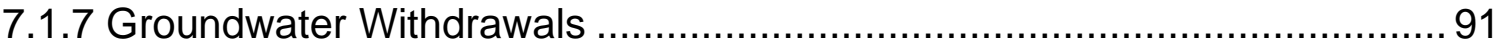

7.1.8 Hydraulic Conductivity and Porosity in the Shallow System .................... 91

7.1.9 Hydraulic Conductivity and Porosity in the Deeper System ..................... 92

7.2 A Preliminary Model Result and Discussion ..................................................96

7.3 Working Towards a Calibrated and Tested Model ........................................ 99

Section 8: Summary, Conclusions and Recommendations............... 101

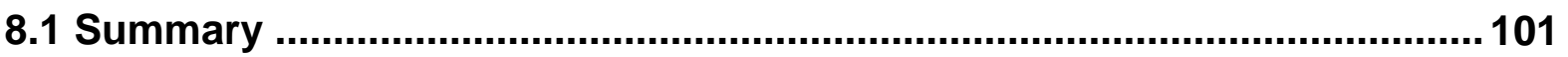

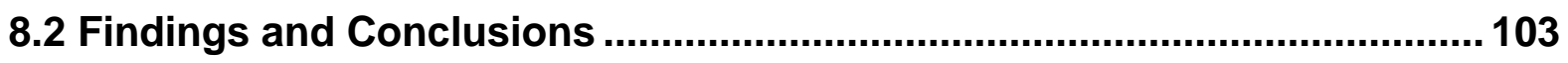

8.3 Additional Recommendations .................................................................. 104

8.3.1 Continued Groundwater Model Development...................................... 104

8.3.2 Additional Isotopic Sampling in the East Mesa .................................... 104

8.3.3 Precipitation, Runoff, and Evapotranspiration Along the Western Basin . 104

8.3.4 Further Evaluation of the Deeper Aquifer Flow System ........................ 104

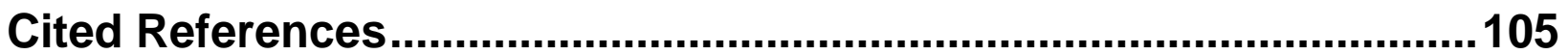

Appendix A: Estimation of Precipitation Excess (PE) in the Salton Sea Basin ................................................................................................ 111

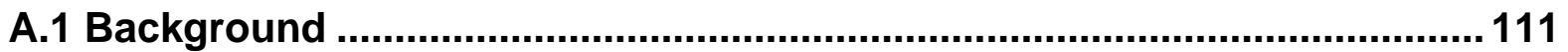

A.2 Data, Theory, and ArcGIS Implementation............................................... 112

A.2.1 Precipitation Excess in the Salton Sea Watershed Basin ..................... 115

A.2.2 Precipitation Excess in the Groundwater Basins in the Salton Sea Area 120

A.2.3 Precipitation Excess in the Groundwater Model Domain ..................... 121

A.2.4 Average Reference Evapotranspiration Rate in the Imperial Basin......... 121

A.3 Potential Improvements.......................................................................... 121

Appendix B: Current Reference Literature Database ......................... 123

Appendix C: Table Descriptions in Current Salton Sea Water Resource Database ............................................................................. 136

Appendix D: Data and Data Sources Reflected in the Salton Sea Database 


\section{Appendix E: Other Tracers used for Groundwater Dating and Source}

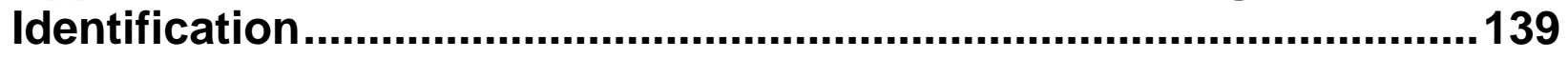

Appendix F: Water Level Data for Model Initialization........................142 


\section{Executive Summary}

\section{Background}

The Salton Sea Basin is a closed topographic basin located in southeastern California and a portion of Baja California, Mexico. It extends, in the north, from the Coachella Valley in San Bernardino and Riverside counties southward into the Imperial Valley in Imperial and San Diego counties and further south into the Mexicali Valley in Mexico. At its lowest point, the basin encompasses the Salton Sea, the largest lake in area in California. At its current elevation (229 ft, or $70 \mathrm{~m}$ below sea level), the Sea has a maximum depth of about 50 feet (15 meters), an average depth of 30 feet $(9 \mathrm{~m})$, and a total surface area of 359 square miles $\left(230,000\right.$ acres or $\left.931 \mathrm{~km}^{2}\right)$.

Despite its arid climate, the Salton Sea Basin is home to some of the most productive agricultural lands in the United States. These include approximately 100,000 acres of irrigated cropland in the Coachella Valley north of the Sea and 525,000 acres in the Imperial Valley, south of the Sea. In addition, there are also extensively irrigated lands in the Mexicali Valley to the far south of the Sea. The existence of the Sea we know today is intimately tied to agriculture, as it was created in the early $20^{\text {th }}$ century from a flood along the Colorado River that was routed through new irrigation canals being constructed in the Basin. It survives to this day in a delicate balance in which vast evaporation losses (that comprise the only form of output) are offset by irrigation returns and discharges from surrounding agricultural lands. This process has lead to increasing salinity in the Sea derived from salts in the agricultural drainage, which itself, is serving to impact and disrupt the rich and diverse ecology that has become established in the Sea.

The Colorado River provides most of the water used for agricultural purposes in the Basin. Over 3.2 million acre-feet of water are imported from the Colorado River on an average annual basis through the All American Canal. Over $90 \%$ of this total is used in the Imperial Valley, with the remaining amount routed to the Coachella Valley through the Coachella Canal. The Coachella Valley also receives water from the California State Water Project. Groundwater is the only other source of water in the Basin, its use is concentrated mostly in the Coachella Valley for domestic purposes, owing to greater sustainability of natural recharge and growing use of aquifer storage and recovery projects to support increasing urban demands. Groundwater use in the Imperial Valley is much lower, owing to the wide availability of imported water, much lower urban demands, and water production and quality limitations.

This report describes the development of an integrated groundwater availability assessment for the Salton Sea Basin. Renewed interest in groundwater as an additional water supply, especially in the Imperial Valley, has been motivated by

- Increasing demands for Colorado River water from urban centers outside of the Basin (e.g., San Diego);

- Reduced Colorado River allocations for California, including the Imperial Valley, resulting from a recent Federal and Sate agency agreements; and 
- Potential new needs for water to support various Salton Sea restoration alternatives focused on salinity reduction and/or/broader ecological preservation efforts.

\section{Groundwater Availability in the Basin}

In the current context, groundwater availability is defined by volume and capacity of the basin (e.g., storage), producibility of groundwater, quality of groundwater, and the overall potential for sustained renewability of groundwater.

As a whole, groundwater storage in the basin is very large, potentially as high as 4.5 to 6.5 billion acre-feet (AF) in current estimates, yet much of this is confined to greater depths where quality is poor (high salinity), producibility is low (poor permeability and accessibility) and natural recharge, required for sustained use as a supply, is not well demonstrated from available data.

Historically producible groundwater in the basin has been confined to a "shallow" system, extending to no more than $2,000 \mathrm{ft}$ deep in most areas, and which is typically considered to be isolated from a "deeper" system that can extend to as much as 20,000 ft in depth. Producibility conditions in the shallower system can vary from very good to very poor. In the central Imperial Valley, for example, poor producibility is often associated with low permeability sediments associated with Colorado River delta deposits, while larger permeabilities can be found in many perimeter areas of the valley, as well as in the Coachella Valley to the north where these lower permeability materials are less prevalent. Similarly, groundwater quality conditions in the shallow system can also vary widely across the basin, and often show high salinities derived from mineralogic or ancient seawater sources, agricultural return flows, or other wastewaters.

Groundwater renewability in the shallow system, as realized through groundwater recharge, is dominated in the southern portion of the basin by Colorado River water derived from irrigation returns in the agricultural areas, localized canal leakage along the All American and Coachella Canals, or from the River itself along the southern basin boundary in Mexico. Precipitation-based recharge is very low over much of the basin, although is highest in the western and northwestern perimeter mountain front areas, especially in the Coachella Valley where production from artesian wells, derived from natural recharge, is significant. Artificial aquifer storage and recovery (ASR) projects are also used as a means of recharge, again, primarily, in the Coachella Valley.

Within the US side of the basin, any significant additional groundwater production would have to be sustainable in the sense that it is balanced by existing or potential new sources of recharge. In the Coachella Valley, increased production in the shallow system has been made possible through ASR projects that yield close to 220,000 AF/year in additional recharge and production capacity. In the Imperial Valley, increased production opportunities in the shallow system are limited to (i) potential areas in the West Mesa fed by mountain front runoff and (ii) opportunities to utilize excess Colorado River water to support an ASR project in the East Mesa, mimicking or continuing, in a sense, the canal leakage processes that have been occurring since the 1940s. Increased production opportunities in the deeper system may be possible, but may be 
hampered by the producibility, quality, and renewability concerns mentioned above, as well as other impacts such as subsidence.

In many areas of the Imperial Valley, groundwater in storage has been decreasing as a result of increased domestic production, suggesting that the newer production may not be offset by existing recharge. In some West Mesa areas, this is not yet the case, but total production should, to the first order, not to exceed potential (natural) recharge, which has been estimated to be quite small. A more promising approach would be to develop an ASR-like project in the East Mesa and to assess its viability through renewed analyses of the $60+$ years of canal leakage that has been occurring from the Coachella and All American Canals.

\section{Project Objectives}

In order to advance the development of this groundwater availability assessment, the work in this project was focused on two principal activities. In Phase I, in cooperation with staff of the U. S. Bureau of Reclamation ("Reclamation"), Lower Colorado Region office, we established and implemented a baseline process to acquire, assemble, organize, and make accessible as much of the existing and relevant hard data and interpretive information as possible that relate to quantifying groundwater availability in the Salton Sea area. This effort is viewed as an essential integrative process that compiles as much available information as possible from all potential sources, in one place, and in a manner that will allow for continuous expansion and updating within a defined data structure and format over time. This phase was seen as a process that would enable the acquisition and more effective interpretation of data for assessment purposes. Specifically, Phase I activities included

- Designing and implementing two electronic, web-based hierarchical databases one for all pertinent Hard Data, and the other for all related Interpretive Information literature;

- Designing and implementing a related Geographic Information System (GIS), dynamically linked to these databases; and

- Acquisition, review, assembly, and organization of as much of the available Hard Data and Interpretive Information as possible into these databases, allowing for continual updating as necessary

In Phase II, the results of Phase I were reviewed, also in cooperation with Reclamation staff, and were considered as a basis to develop new information related to groundwater source, age, and quality in the East Mesa as a means to better characterize flow and recharge pathways in the region. Specifically, we

- Developed and implemented a groundwater isotope sampling study in the East Mesa as a means to detect and determine historical recharge patterns and flow rates

In addition, Phase II work also included

- Initial development of a more integrated conceptual flow model for the basin as a whole, as a means for groundwater flow model development; 
- Initialized the development of a regional groundwater flow model in the Imperial and Mexicali Valleys as a means to assess the potential for groundwater banking opportunities and the viability of new production in the West Mesa areas.

\section{Findings and Conclusions}

Within the US side of the basin, any significant additional groundwater production would have to be sustainable in the sense that it is balanced by existing or potential new sources of recharge. In the Coachella Valley, increased production in the shallow system has been made possible through ASR projects that yield close to 220,000 AF/year in additional recharge and production capacity. In the Imperial Valley, increased production opportunities in the shallow system are limited to (i) potential portions of the West Mesa groundwater basins fed by mountain front runoff, and (ii) opportunities to utilize excess Colorado River water to support an ASR project in the East Mesa, mimicking or continuing, in a sense, the canal leakage processes that have been occurring since the 1940s. Increased production opportunities in the deeper system may be possible, but may be hampered by the producibility, quality, and renewability concerns mentioned above, as well as other impacts such as subsidence.

With regard to (i), precipitation-based recharge rates in the western perimeter groundwater basins are not large, yet they are among the highest in the Imperial Valley as a whole. Many of these basins include a number of highly productive wells, yet have, in general, stable to declining water level trends that can be correlated to steady increases in local production over the past half century. Notably, the Vallecito-Carrizo basin has been showing rising levels of groundwater to the tune of 10 to 20 feet over the same period. Although it has an estimated recharge rate of $\mathbf{2 , 0 0 0} \mathbf{A F} / \mathbf{y}$, this value could be much higher if runoff from the western mountain fronts were taken into account in the estimation process, but it is certainly limited by the local $\sim \mathbf{6 0 , 0 0 0} \mathrm{AF} / \mathbf{y}$ precipitation rate that contributes to runoff and recharge in the immediate basin area. This suggests that increased rates of renewable groundwater production in this basin may not be sustainable at large levels even though the cited recharge rate may underestimate the actual value. Application of better rainfall-runoff models in the greater West Mesa and upper watershed areas, for example, will lead to more accurate recharge estimates. Additionally, application of calibrated groundwater models in the Vallecito-Carrizo basin will be effective in planning and optimizing any new water extraction scenarios in the future.

With regard to (ii), one promising approach for development of new groundwater resources in the Imperial Valley would be to develop an ASR-like project in the East Mesa and to assess its viability through renewed analyses of the $60+$ years of canal leakage that has been occurring from the Coachella and All American Canals. For the AAC specifically, aggregate losses between 1948 and 1988 totaled 4.9 MAF (or 123,000 AF/y on average), yet estimates of accrued increases groundwater in storage under the canal lay only between 700,000 AF and 1.5 MAF. Quantification of this difference and the mechanisms that contribute to it (e.g., steady losses to evapotranspiration, discharges into agricultural drains and canals, etc.) will be critical to the efficacy and design criteria for any ASR project in this particular area. Isotopic analyses of groundwater in the area have proven useful in the identification of the source and ages of water in and around the existing mound, but clearly need to be augmented with additional sampling locations. Application of calibrated groundwater models in the East Mesa have been and will continue to be effective tools in this design and assessment process. 


\section{Additional Recommendations}

Recommendations included in the report focused on suggestions to extend this work in three primary areas:

1. Continue the development, calibration, and application of the regional groundwater flow model as a means to both (i) design and evaluate the efficacy of ASR schemes in the East Mesa area and (ii) evaluate possibilities and limits of increased groundwater production in the West Mesa area;

2. Perform additional isotopic sampling and interpretation studies in the East Mesa area through the installation of several multilevel monitoring wells, as a means to further quantify historical groundwater flow and storage behavior in the East Mesa area arising from canal leakage, and as a means to further calibrate the regional groundwater flow model in this area; and

3. Further evaluation of precipitation, runoff, and evapotranspiration processes along the mountain front regions along the western perimeter of the basin as a means to (i) better quantify the shallow groundwater recharge in the West Mesa and nearby areas and (ii) define a more reliable upper-bound estimate of the sustainable "safe" groundwater yield in these areas. 



\section{Section 1: Introduction}

\subsection{Background}

It is widely recognized that increasing demands for water in Southern California are being affected by actions to reduce and redirect the amount of water imported from the Colorado River. In the Imperial Valley region, for example (Figure 1.1), import reductions will not only affect agricultural users but also could produce significant collateral impacts on the level and quality of water in the Salton Sea, its regional ecology, or even the long term air quality in the greater basin (Cohen, et al., 1999; Weghorst, 2001; Cohen, 2005).

The notion of using groundwater in the Imperial Valley as an additional source for agricultural or domestic needs, energy production, or Salton Sea restoration efforts, so as to offset reductions in imported water, is not a new concept. Even though it has been discussed recently (e.g., LLNL, 2002), the idea goes back, in part, to several studies performed by the US Department of Interior and other agencies that have indicated that there may be substantial, usable amounts of groundwater in some portions of the Imperial Valley (e.g., Dutcher et al., 1972; Loeltz et al., 1975; Loeltz et al., 1979). It has been estimated, for example, that between 1.1 and 3 billion acre-feet (AF) of groundwater ${ }^{1}$ lie within the extended, deep basin underlying the valley and Salton Sea region, even though much of it may be unrecoverable or too poor in its quality (Imperial County, 1997). This is a significant volume with respect to the total annual precipitation volume received in California, whose average is close to 200 million (or 0.2 billion) AF per year (DWR, 1998), and especially with respect to the total annual precipitation received in the Salton Sea watershed itself, which we estimate (Appendix A) to be approximately 2.5 million acre feet (MAF) per year.

Clearly, a thorough appraisal of the groundwater resources in the Imperial Valley and Salton Sea region - i.e., an assessment of their overall physical availability - will be needed to determine how they can be used and managed to suit new or redirected demands in the region. Development of an improved or updated groundwater assessment in the Salton Sea Basin is the subject of the project described in this report. Much of the project work was done in cooperation with the US Bureau of Reclamation, Lower Colorado Region Office ("Reclamation"), which manages the Salton Sea Restoration project for the US Department of the Interior, and complements other recent assessment efforts (e.g., Imperial County, 1995).

In this context, the notion of groundwater availability is defined by four separate, but interrelated concepts or components ${ }^{2}$ :

\footnotetext{
${ }^{1}$ An acre-foot (AF) is a commonly used volumetric measure of water, where $1 \mathrm{AF}=1,233.5 \mathrm{~m}^{3}$ or $1 \mathrm{~km}^{3}=$ 810,701 AF.

${ }^{2}$ Note that we will specifically not consider any legal, judicial or accessibility issues that could affect or relate to groundwater availability.
} 
1. Volume and Capacity - This refers to the volume of groundwater available in storage in (or the related storage capacity of) the sediments and geologic media that comprise a groundwater basin. The volume of groundwater in a basin will vary in time as a function of recharge, well production, and land subsidence.

2. Producibility - This refers to the ease or difficulty of extracting groundwater in a basin from wells. Groundwater producibility will be affected by well depth and the formation permeability surrounding the open intervals in wells.

3. Quality - This refers to the extent that water produced from wells is potable or otherwise suitable for domestic or other uses. It may also refer to the chemical compositions of groundwater that are unrelated to potability or suitability issues. Groundwater quality will be affected by its residence time and flow pathway in the formation and will also be influenced by the quality of its original source before entering the groundwater regime.

4. Renewability and Recharge - This refers to the extent that groundwater is recharged to the basin as part of the natural hydrologic cycle or other artificial means. Groundwater renewability is normally a function of recharge derived from precipitation (and thus a function of regional climate), but may also be affected in local areas by irrigation, leaking canals, aquifer storage and recovery operations, and so forth. Along with the other factors, renewability will strongly affect how much water can be safely produced from a basin from one year to the next.

In this report, we specifically consider two categories of information that comprise, are pertinent to, or facilitate such a groundwater assessment. The first category includes the vast assortment of descriptive geologic, hydrologic, chemical, and climatic data related to the regional groundwater aquifers in the Salton Sea area and the occurrence, movement, production, and quality of groundwater. We will refer to these as Hard Data. They may include, for example, spatially distributed geologic or lithologic information, operational wells, water level monitoring data, and well production reports, groundwater quality information, other land use information, historical precipitation and climatic records, and so forth, The second category includes more interpretive or analytic information based upon, or derived from these data and knowledge of related geologic, hydrologic, chemical, or climatic processes. We will refer to this category as Interpretive Information. It may include, for example, conceptual geologic or hydrostratigraphic models of the basin, quantitative mathematical models to understand groundwater behavior under historical or proposed aquifer management scenarios, and so forth.

In the case of the Salton Sea region, much of this kind of information already exists and is in the hands of numerous local, state, and federal agencies, commercial enterprises, private entities, and educational and research institutions. But, unfortunately, much of it is

- Disparate and spread apart because of multi-agency "ownership";

- Associated with narrow sectors of interest in the areas of agriculture, municipal or private water needs, geothermal energy production, and the ecological and environmental water requirements of the Salton Sea itself;

- Related to small or restricted areas in the basin as a whole; or

- Proprietary in nature in some cases. 
This level of organization can make management of groundwater in the basin as a whole more difficult. 


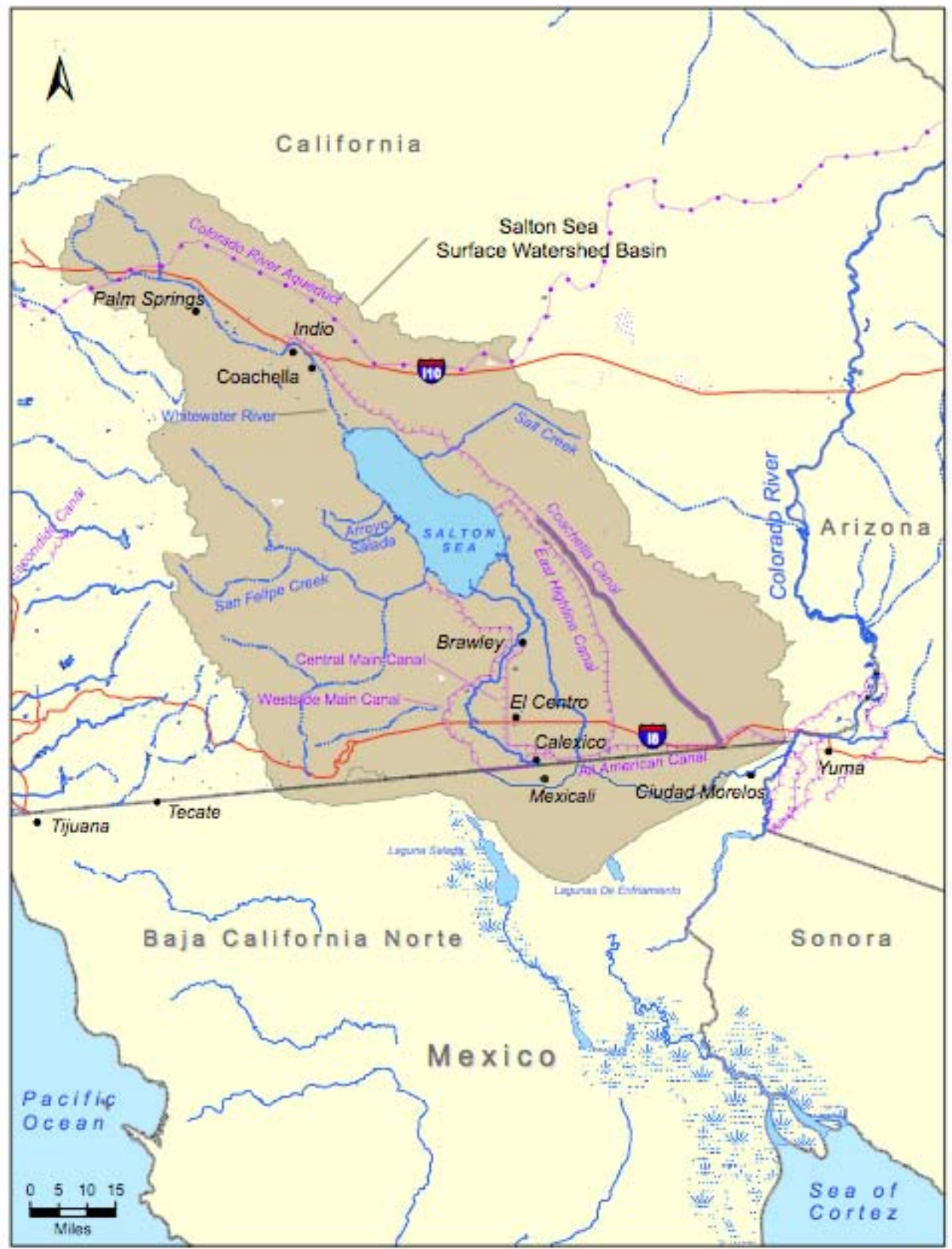

Figure 1.1: Map of the greater Salton Sea area in Southern California and Baja California Norte showing the Colorado River, imported water aqueducts (purple), and regional watershed basin (shaded, $8360 \mathrm{mi}^{2}$, or $21,700 \mathrm{~km}^{2}$, in area). A thick gray line indicates the lined portion of the Coachella Canal. 


\subsection{Project Objectives}

The objectives of this project, developed in coordination with the staff of the U. S. Bureau of Reclamation, are twofold. In Phase I, we establish and implement a baseline process to acquire, assemble, organize, and make accessible as much of the existing and relevant Hard Data and Interpretive Information as possible that relate to quantifying groundwater availability in the Salton Sea area. This effort is viewed as an integrative process that compiles as much available information as possible from all potential sources, in one place, and in a manner that will allow for continuous expansion and updating over time. Specifically, Phase I activities included

- Designing and implementing two electronic, web-based hierarchical databases one for all pertinent Hard Data, and the other for all related Interpretive Information literature;

- Designing and implementing a related Geographic Information System (GIS), dynamically linked to these databases,

- Acquisition, review, assembly, and organization of as much of the available Hard Data and Interpretive Information as possible into these databases, allowing for continual updating as necessary; and

- Development of a secure website to serve as an information portal for the project and, ultimately, for the sponsor (US Bureau of Reclamation, or "Reclamation") to make available to a wider audience.

In many respects, this effort is consistent with a broader Salton Sea Database Program developed and described by the Redlands Institute (2002).

In Phase II, the results of Phase I were reviewed with Reclamation staff and considered as a basis to develop additional data acquisition and interpretation activities related to the broad aims of the Groundwater Availability project. Specifically, activities in Phase II included

- Collecting new data through potential activities such as pump tests, groundwater sample collection and chemical analysis, or possibly installing a new groundwater well in a poorly characterized area;

- Development of new isotopic information related to groundwater source, age, and quality, as a means to better characterize flow and recharge pathways in the East Mesa area;

- Development of a more integrated conceptual flow model for the basin as a whole, as a means for groundwater flow model development;

- Initializing the development of a regional groundwater flow model between the Coachella Valley on the North and Mexico on the South or a smaller area of interest;

- Assessing the potential for using groundwater in Salton Sea restoration as well as potential groundwater banking opportunities in the basin; and 
- Simulating alternative extraction and or recharge recovery scenarios to determine aquifer responses and future information requirements.

Following the completion of this project, the existing database and related constructs will be transferred to Reclamation. Arrangements will be made, subject to Reclamation approval, to make the data publicly accessible and available for continued development, management, and improvement (through Reclamation, LLNL, or other agency).

\subsection{Report Organization}

In Section 2 of this report, we provide a brief synopsis of the physical setting of the Salton Sea basin, especially as it relates to the overall nature of groundwater occurrence. This involves a discussion of the geology of the basin, historical processes related to the original occurrence of groundwater in the basin, and a review of the present day hydrology and water resources in the basin.

In Sections 3 and 4, we describe the database and GIS development activities conducted in Phase I and present various applications of their results.

In Section 5, we review the options considered for Phase II activities and the rationale that was eventually used to finalize them. This eventually led to the design and implementation of a groundwater sampling and isotopic analysis activity in the East Mesa area, as described in Section 6, and the initial development of a groundwater model for use in the Imperial Valley, as described in Section 7.

Section 8 presents a summary of the effort as a whole. This includes an series of conclusions focused on what we have learned that is pertinent to the objectives of the project and a set recommendations for additional work.

A number of appendices are also included. Appendix A provides a review of an effort to better estimate precipitation, precipitation excess, and groundwater recharge in the Basin, as an ultimate means to better bound the upper sustainable groundwater yields of the groundwater system in various areas. Appendices B-F provide additional database and related information pertinent to Phase I and II activities. 


\section{Section 2:}

\section{Physical Setting and Groundwater Occurrence}

\subsection{Physical and Geologic Setting}

The Salton Sea is located in Riverside and Imperial counties of southeastern California (Figure 2.1). The overall Salton Sea Basin, including the Salton Sea and its surrounding closed watershed extends further into San Bernardino and San Diego counties, as well as into the Mexicali Valley of Baja California, Mexico. The Salton Sea is the largest lake in area in California, some 35 miles ( $56 \mathrm{~km}$ ) long, 9 to 15 miles (14 to $24 \mathrm{~km})$ wide, and with about 120 miles $(190 \mathrm{~km})$ of shoreline. At its current elevation, the Sea has a maximum depth of about 50 feet (15 meters), an average depth of 30 feet $(9 \mathrm{~m})$, a total surface area of 359 square miles $\left(230,000\right.$ acres or $\left.931 \mathrm{~km}^{2}\right)$, and a total water volume of 7.2 million acre-feet (MAF).

The Salton Sea occupies the lowest portion of a rift valley called the Salton Trough. This is a deep sediment-filled structural as well as topographic depression that is bounded by the Santa Rosa Mountain range to the northwest, the Orocopia Mountain range to the northeast, the Chocolate Mountain range to the east, and the Peninsular Mountain ranges of Southern and Baja California to the southwest. It extends linearly in a southeast to northwest direction from the Gulf of California, through the Mexicali Valley in Mexico, and in the United States through the Imperial Valley south of the Salton Sea and the Coachella Valley north of the Salton Sea. The basin experiences an arid, low-rainfall desert climate, with summer temperatures often exceeding $100^{\circ} \mathrm{F}\left(38^{\circ} \mathrm{C}\right)$. Precipitation in the central parts of the basin is very low, typically averaging $2.5 \mathrm{in}(64 \mathrm{~mm})$ per year, although higher amounts (over $35 \mathrm{in}$, or $900 \mathrm{~mm}$ ) occur in the surrounding mountains to the west. The regional watershed basin shown in Figure 2.1 encompasses $8,360 \mathrm{mi}^{2}$ (or $21,700 \mathrm{~km}^{2}$ ) in area.

\subsubsection{Surface Water Hydrology}

The surface water elevation in the Salton Sea is approximately 229 feet $(70 \mathrm{~m})$ below sea level. Much of the land in the surrounding Salton Sea Basin is also below sea level (Figure 2.1). As it occupies the lowest portion of the Salton Trough, the Sea is a terminal lake from which there is no surface outflow. Water inflows occur primarily from the Alamo, New, and Whitewater Rivers, agricultural drains, groundwater inflows, spring discharges, and other ephemeral runoff from rainfall, amounting to approximately 1.35 million AF per year (Table 2.1).

In the South, inflows from the Alamo and New Rivers comprise over $80 \%$ of the inputs to the Salton Sea. Much of these inflows are comprised by agricultural runoff or other wastewaters originally derived from the Colorado River. About $16 \%$ of the flow in these rivers alone is derived from inflows originating in the Mexicali Valley in Mexico. In the North, inflows from the Whitewater River also represent agricultural and some precipitation-based runoff derived from the slopes of Mt. Gorgonio. Salt Creek is the major drainage feature along the eastern side of the basin, draining the southern slopes of the Orocopia Mountains and the northwest end of the Chocolate Mountains. It is largely ephemeral, although its lower reaches are fed by discharges from Dos Palmas Springs. The most important western drainage in the basin is San 
Felipe Creek, which originates in the Peninsular Mountains 50 miles west of the Salton Sea. It is ephemeral in its upper reaches, but is also fed by perennial hot springs near its discharge point into the Salton Sea.

Table 2.1. Water inflows to the Salton Sea for 1999 (after Weghorst, 2001)

\begin{tabular}{|c|c|c|}
\hline Source & Subtotal $\left(\mathbf{A F ^ { 1 }}\right)$ & Total (AF) \\
\hline Alamo River (total) & & 643,426 \\
\hline Alamo River (Mexico) & 1,668 & \\
\hline Alamo River $\left(I I D^{1}\right)$ & 641,758 & \\
\hline New River (total) & & 465,779 \\
\hline New River (Mexico) & 176,447 & \\
\hline New River (IID $\left.{ }^{1}\right)$ & 289,332 & \\
\hline IID $^{2}$ (direct) & & 94,414 \\
\hline CVWD $^{3}$ (surface, including the Whitewater River) & & 81,765 \\
\hline CVWD (aquifer) & & -366 \\
\hline Precipitation and other unmeasured flows & & 68,400 \\
\hline OVERALL TOTAL & & $1,353,418$ \\
\hline
\end{tabular}

One acre-foot $(\mathrm{AF})=1,233.5 \mathrm{~m}^{3}$ or $1 \mathrm{~km}^{3}=810,701 \mathrm{AF}$.

${ }^{2} \mathrm{IID}=$ Imperial Irrigation District

${ }^{3} \mathrm{CVWD}=$ Coachella Valley Water District

The All American Canal (AAC) delivers water to the basin from the Colorado River. It extends over 80 miles inland from its Imperial Dam diversion point and parallels the US Mexico border into the Imperial Valley. The AAC ultimately delivers water to support roughly 525,000 acres of cropland in the Imperial Valley where additional networks of smaller canals, including the East Highland Canal, Westland Canal, and other lateral diversions partition this delivery network further. A separate irrigation drainage system exists consisting of about 112 miles of closed drains and 1,341 miles of open drains feeding discharged water into the Salton Sea, either directly, or through the New and Alamo Rivers. Altogether, the total length of canals and drains in the Imperial Valley is approximately 3,100 miles. The Coachella Canal (CC) is a 123-mile long branch of the AAC extending from Drop 1 of the AAC, near the East mesa, northward into the Coachella Valley. The CC imports support an additional 100,000 acres of cropland as well as additional urban and Aquifer Storage and Recovery (ASR) operations in the Coachella Valley. Water is also imported to the Coachella Valley from the State Water Project (CVWD, 2006). Approximate flow rates and leakage rates in these canals are given in Table 2.2.

Water losses from the sea are in a dynamic equilibrium with water inputs and occur strictly through evaporation from the surface. As a result, the current salinity of water in the Sea, as accrued over time from salts in the inflows, is approximately $46 \mathrm{~g} / \mathrm{L}$, significantly higher than the salinity of seawater $(33 \mathrm{~g} / \mathrm{L})$. Other contaminants in the inflows build up over time as well (Cohen at el., 1999). 
Table 2.2. Salton Sea basin imported water summary, including canal losses c1988

\begin{tabular}{|c|c|c|c|}
\hline Source & $\begin{array}{l}\text { Metered Flow } \\
\left(\mathrm{AF} / \mathbf{y}^{1}\right)\end{array}$ & $\begin{array}{l}\text { Metered Loss } \\
\text { (AF/y) }\end{array}$ & $\begin{array}{l}\text { Adjusted Loss } \\
\text { (AF/y) }\end{array}$ \\
\hline All America Canal, below Pilot Knob & $3,279,000$ & & \\
\hline Rock 2/Pilot Knob to Drop 1 & & 65,000 & 59,187 \\
\hline All America Canal, below Drop 1 & $2,885,000$ & & \\
\hline Drop 1 to Drop 2 & & & 17,883 \\
\hline Drop 2 to Drop 3 & & & 7,415 \\
\hline Drop 3 to Drop 4 & & & 7,084 \\
\hline Drop 4 to East Highline Canal & & & 2,637 \\
\hline Drop 1 to East Highline Canal & & 44,000 & \\
\hline All America Canal, before $\mathrm{EHC}^{4}$ & 2,849,981 & & \\
\hline TOTAL AAC losses & & 109,000 & 94,206 \\
\hline Coachella Canal, from Drop $1^{4}$ & 334,813 & & \\
\hline TOTAL CC losses 5 & & & 26,000 \\
\hline $\begin{array}{l}\text { State Water Project pipeline imports to } \\
\text { Coachella Valley }^{6}\end{array}$ & 171,000 & & \\
\hline
\end{tabular}

One acre-foot $(\mathrm{AF})=1,233.5 \mathrm{~m}^{3}$ or $1 \mathrm{~km}^{3}=810,701 \mathrm{AF}$.

${ }^{2}$ As shown in Reclamation 1994, Table 1, for 1988

${ }^{3}$ As calculated in Reclamation 1994, Table 3

${ }^{4}$ As calculated using metered flows and adjusted losses for 1988

${ }^{5}$ As estimated in Reclamation 1993, Table 1, for an unlined stretch between Siphons 7 and 32; average value shown; An additional $796 \mathrm{AF} / \mathrm{y}$ loss occurs in the in lined section of the canal (Tetra Tech, 1999)

${ }^{6}$ Amount varies as a function of State Water Project uncertainties (CVWD, 2006)

\subsubsection{Groundwater Hydrology}

The Salton Trough overlies a deep underground basin extending to depths of 20,000 ft (or $6,100 \mathrm{~m}$ ) or more in some locations (Figures 2.2 and 2.3). The upper portion of the basin is composed of inter-bedded alluvial and lakebed deposits, at most a few thousand feet thick. More consolidated deposits and a fractured rock "basement complex" (including volcanic rock and portions of the Brawley, Borrego, Palm Spring, and Imperial Formations) underlie these materials and extend to deeper bedrock ${ }^{3}$. Groundwater is present throughout the basin. Although estimates as high as 1.1 to 3 billion AF have been made for the total volume of groundwater in storage (Imperial County, 1997), much of it is not considered recoverable because of high salinity, high temperature, or general inaccessibility because of depth or low permeability concerns.

Historically, the shallower basin fill deposits, especially near the basin perimeter where hydraulic conditions are unconfined, have been considered the best water bearing materials in the basin. Confined and lower permeability conditions exist in the shallow materials in the central

\footnotetext{
${ }^{3}$ In some instances, "deeper bedrock" is referred to as the "basement", whence the "basement complex" should be regarded as the formations separating the "basement" from the shallower alluvium, lacustrine, and delta deposits.
} 
basin owing to the greater abundance of lakebed clays, making groundwater less available. Confined conditions also exist in the shallower depths in the Coachella Valley.

\subsubsection{Tectonic and Geothermal Activity}

Historically, the Salton Trough has been a zone of heavy tectonic activity and frequent earthquakes (Figures 2.2 and 2.3). It was created by the relative motion of the North American and Pacific plates over the last 4-5 million years (see, e.g., Dutcher et al., 1972, Loeltz et al., 1975). It represents a region of transition from the divergent plate boundary of the East Pacific Rise to the transform boundary of the San Andreas Fault system. At the present time, the plate motion in the Salton Trough is primarily horizontal (strike-slip) along major faults such as the San Jacinto and Imperial faults. Locally, geothermal hot spots are created by magmatic intrusions in the pull-apart regions (Newmark et al., 1988). Several geothermal energy fields, such as the Salton Sea, Cerro Prieto and Brawley geothermal fields, are located at these hot spots. Here, water temperatures at depths of $8,000 \mathrm{ft}(2,438 \mathrm{~m})$ can exceed $680{ }^{\circ} \mathrm{F}\left(360^{\circ} \mathrm{C}\right)$ (Figure 2.2). While several geothermally active faults penetrate to the surface, most of the tectonically induced faults are located at depth, well below the shallow strata in which most low temperature groundwater is found. Nevertheless, numerous hot wells, hot springs and "mud pots" can be found in the vicinity of surface fault expressions surrounding the inactive Rock Hill, Mullet Island, Obsidian Butte, and Red Island volcanoes near the southern boundary of the Sea (e.g., Redlands Institute, 2002, p.68). Albeit minor and locally confined, these represent some areas where the deeper and shallower groundwater systems are physically and hydraulically connected.

\subsection{Paleohydrology}

Millions of years ago, the Pacific Ocean and the Gulf of California extended much further inland, north through the Salton Trough and close to the present day Indio (Figure 2.4a). The Gulf occupied much of the area within the sea level contour shown in Figure 2.1. The Colorado River emptied into the Gulf at a point close to present day Yuma, AZ. Notably, groundwater occupying the deep formations (Figure 2.3) underlying the extended Gulf at this time was essentially dominated by seawater.

The Colorado River carried large volumes of silts and sediments accrued from its journey through what is now the American West. As depicted in Figure 2.4b, the deposition of these sediments formed a large delta as the Colorado discharged into the Gulf. Over thousands of years, the size of the delta and its amassed sediments grew so large that the northern part of the Gulf became physically separated from the present day Gulf to the south, and the meandering Colorado River veered towards its present day discharge point in Mexico (Figure 2.4c,d). Once this occurred, the residual of the Gulf on the north side of the delta began to evaporate, for lack of any substantive inflows, becoming increasingly more saline. These waters were able to percolate into the subsurface or evaporate further to form halite deposits at the center of the current day Sea (where, in the 19th and early 20th centuries, salt mining was common). 


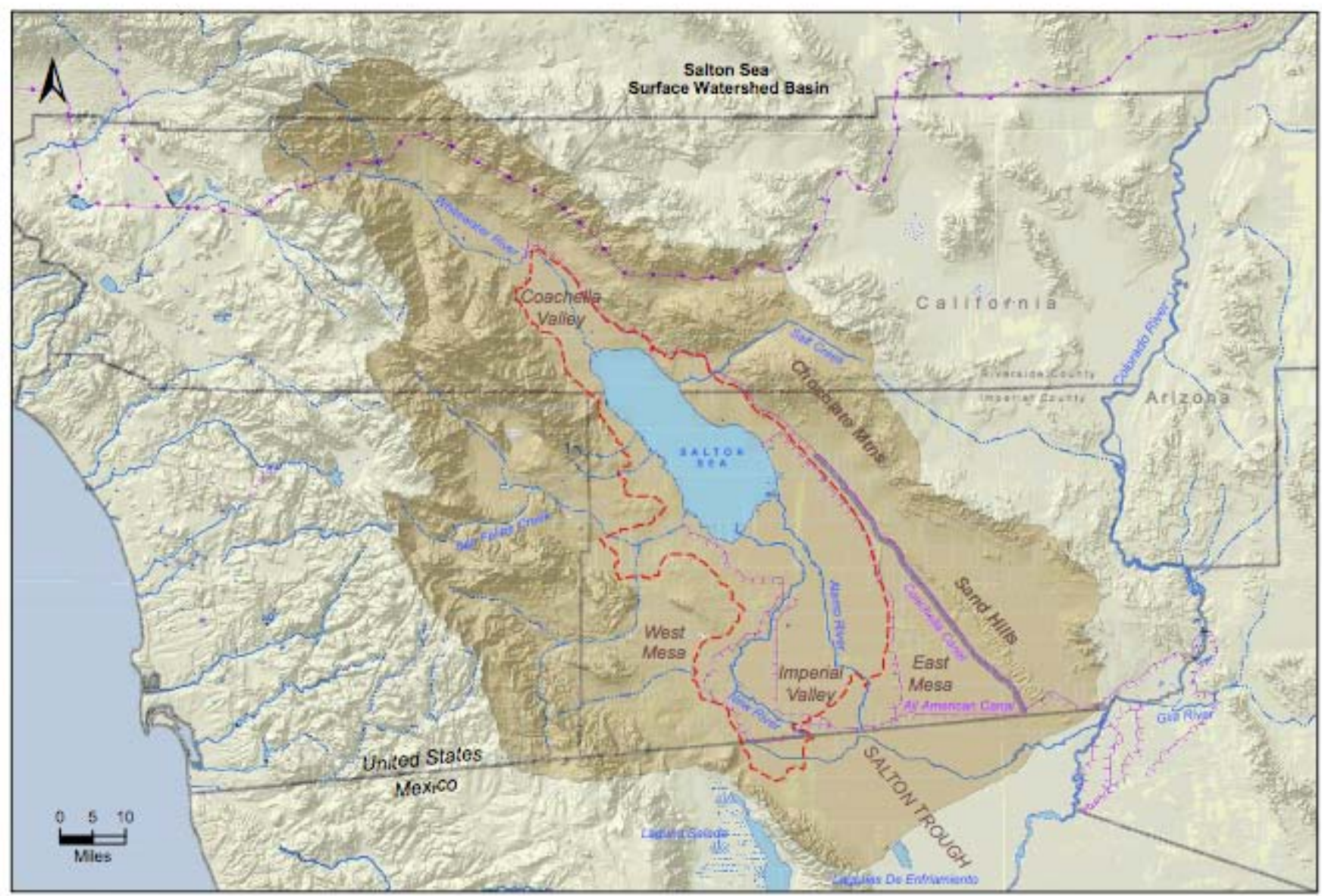

Figure 2.1: Map of the greater Salton Sea area in Southern California and Baja California Norte, similar to Figure 1.1, but showing the sea level elevation contour within the Salton Trough. The shaded area corresponds to the regional watershed basin, $8360 \mathrm{mi}^{2}\left(21,700 \mathrm{~km}^{2}\right)$ in area. Imported water aqueducts are shown in purple. The thick gray line indicates the lined portion of the Coachella Canal. 


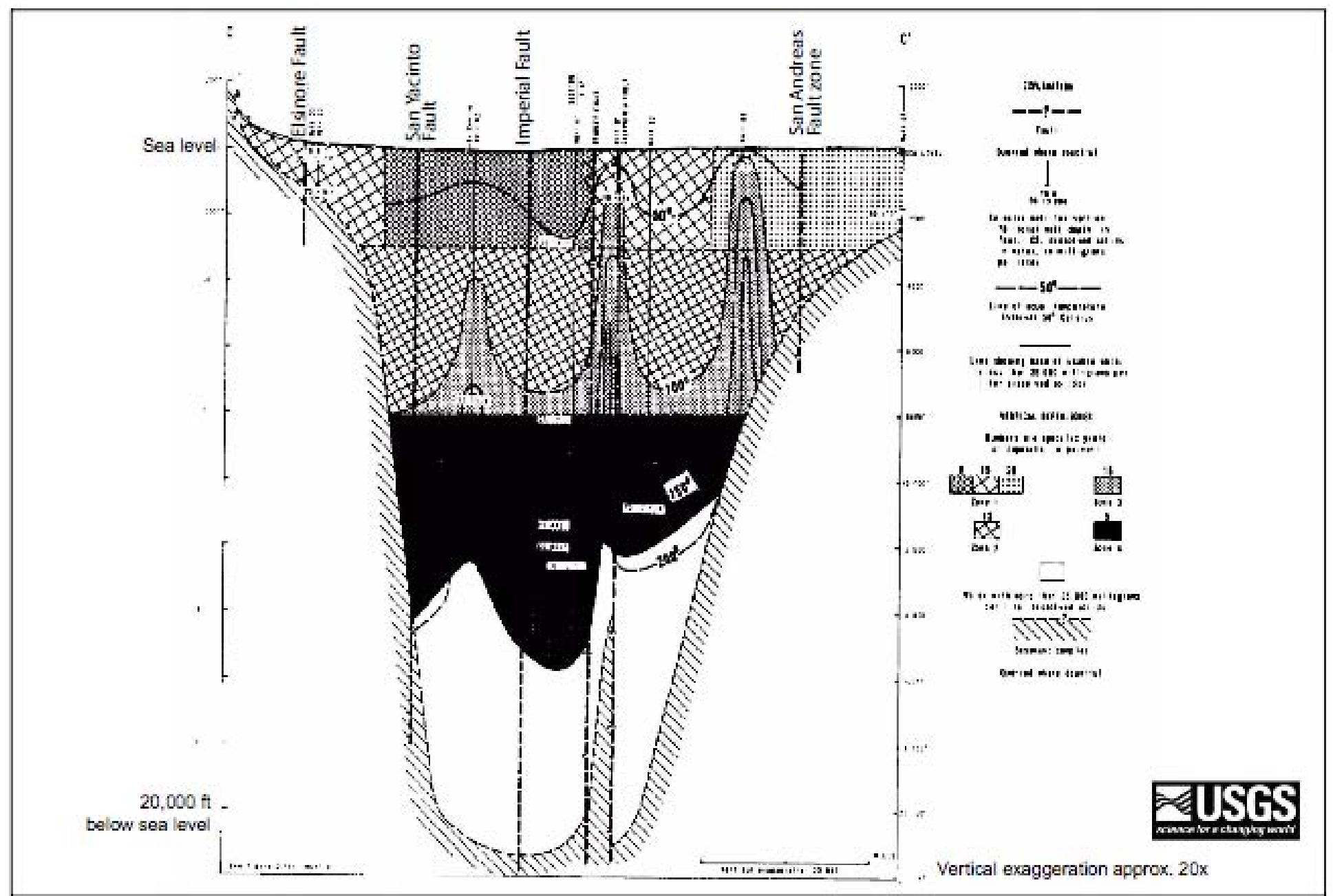

Figure 2.2: West to East geologic cross section through the deeper Salton Sea basin, approximately parallel with the US-Mexico Border (from Dutcher et al., 1972), showing inferred zones of specific yield (porosity) and groundwater temperature $\left({ }^{\circ} \mathrm{C}\right)$. 

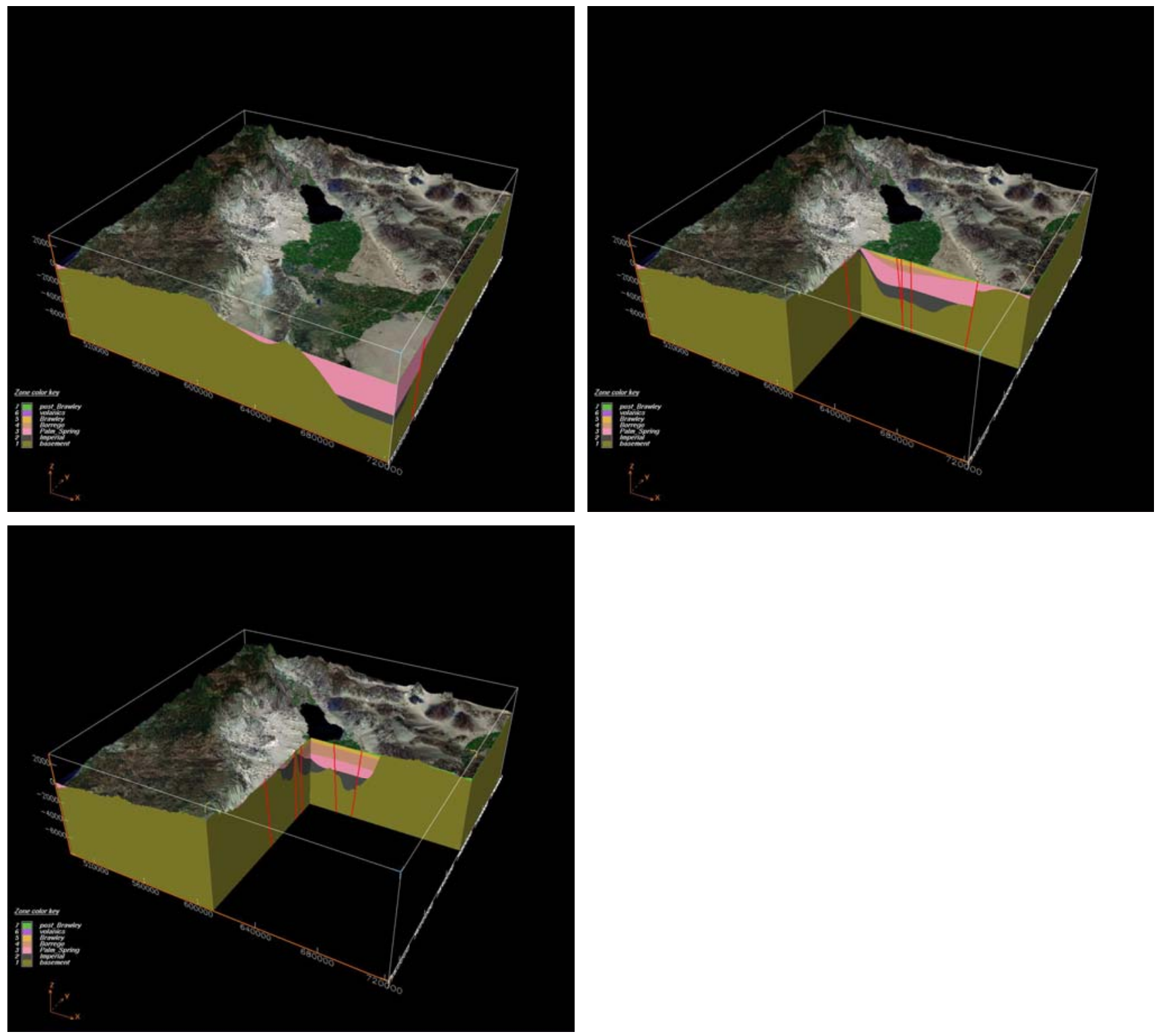

Figure 2.3: Three-dimensional geologic models of the Salton Sea basin, looking North, showing the underlying bedrock, or basement, the overlying Imperial, Palm Spring Borrego, and Brawley formations that comprise the "basement complex", and the postBrawley (delta sediment and alluvial) deposits that extend to the present day surface. The West to East cross-section shown in the second figure corresponds, approximately, to the US-Mexico border and the cross-section in Figure 2.2. The red lines correspond (West to East) to the Elsinore, San Yacinto, Imperial, and San Andreas Fault systems 
Over time, the meandering Colorado would flood and occasionally discharge to the north (Figure 2.4e,f). This process filled in the emptied basin, creating a new, essentially fresh water lake. Then, in the same way, the river would later meander back to a southern discharge point in the Gulf, and the evaporation process in the lake would begin anew. Occasionally, the lake would drain to the Gulf directly while also being filled by the Colorado. This process repeated itself irregularly over a long period of time. The lake that formed, and its subsequent reincarnations, was called Lake Cahuilla. During the past 1,300 years alone, Lake Cahuilla was present more often than not, often much larger than the present day Salton Sea. Its most recent period of existence was between 1600 and $1700 \mathrm{AD}$ (Redlands Institute, 2002).

Much of the shallower sediments within the basin between the Salton Sea and the present day Gulf are reflective of the thick sequences of layered silts, clays and fine-grained sands that were laid down by the Colorado River during the delta formation process and during the episodic flooding that created Lake Cahuilla. Alternating layers of more permeable sands and gravels were also generated in the basin during drier periods. An important result of this depositional process is that it created hydraulically separated and often confined aquifer units, bounded above and below by clay layers, which served to isolate groundwater in the deeper formations from groundwater in shallower ones. The layered silts, clays and fine-grained sands tended to be thicker and more widespread in the center of the basin where flooding occurred most frequently, and thinner along the basin perimeter. This stratigraphy affects the current rates and movement of groundwater flow and groundwater recharge in these areas, and will have influenced hydraulic interactions between Lake Cahuilla and groundwater in the basin in the past.

The Salton Sea of today was created from 1905 to 1907 by a Colorado River flood breaching the headworks of an early irrigation canal built to support developing agriculture in the Imperial Valley (Figure 2.4h). Floodwaters flowed though the canal to the north and refilled the center of the basin, much in the same way that Lake Cahuilla was previously formed. The Union Pacific Railroad spent over a year dumping rock in the river to get the flow turned back to the Gulf.

The Imperial and Coachella Valleys now comprise one of the world's foremost agricultural regions (Figure 2.5). Most of the water used for agriculture is imported from the Colorado River through the All American Canal and distributed to croplands through the Coachella Canal, East Highline Canal, and a number of other feeder channels (Figures 1.1, 2.1 and Redlands Institute, 2002). Small amounts of groundwater are also used for agriculture, mostly in the Coachella Valley.

Agricultural runoff from Imperial Irrigation District (IID) and Coachella Valley Water District (CVWD) drains forms the majority of water inputs to the Salton Sea, along with other inflows from Mexico that pass through the New and Alamo Rivers and some inputs from the Coachella aquifer (Table 2.1). To the extent that Sea levels are steady - they currently fluctuate by more than $1 \mathrm{ft}(0.3 \mathrm{~m})$ annually (Cohen, 2005) - net inflows are balanced by evaporative losses from the Sea surface. Nevertheless, inputs and losses have fluctuated over the past 50 years as a function of changing agricultural water use and pumping from the Coachella aquifer (Weghorst, 2001). As shown in Table 2.1 groundwater pumping in the Coachella Valley is now inducing flow of water from the Sea into the aquifer. Irrigation runoff and water inputs from Mexico represent significant salinity and other contaminant inputs into the Sea, a process that has slowly been contributing to its decreasing water quality (Cohen at al., 1999; Weghorst, 2001). 


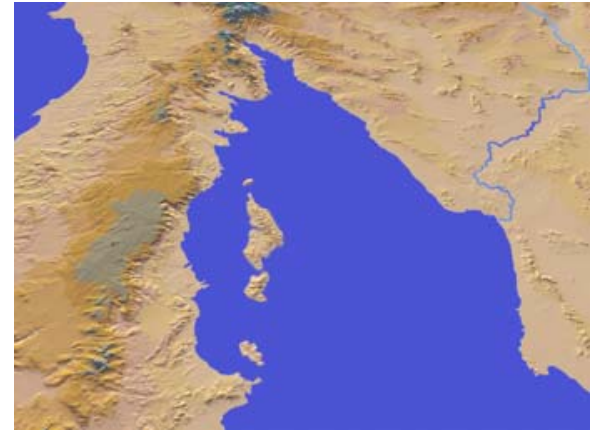

(a) The Gulf of California 12 million years ago

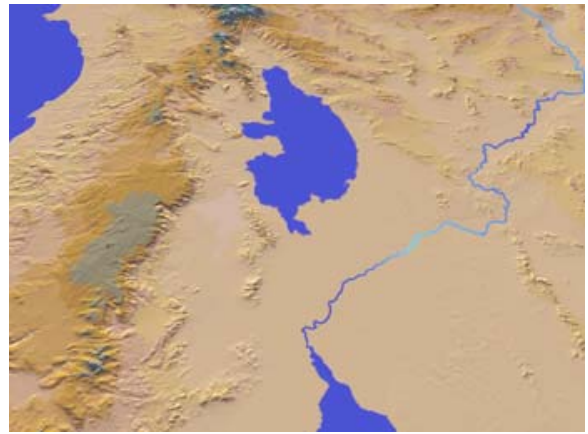

(c) Salton Basin is cut off from the Gulf

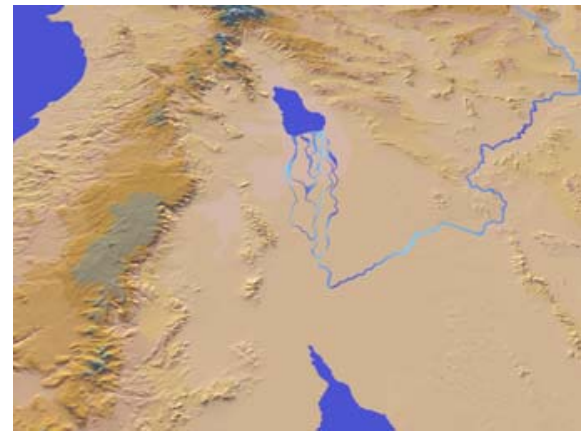

(e) Historically, the Colorado River would periodically shift course

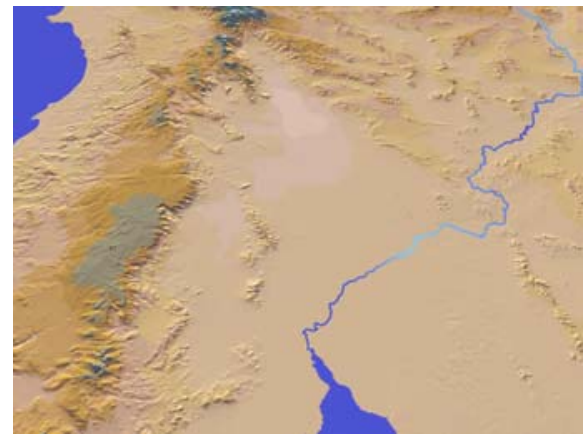

(g) The Salton Trough c. 1900

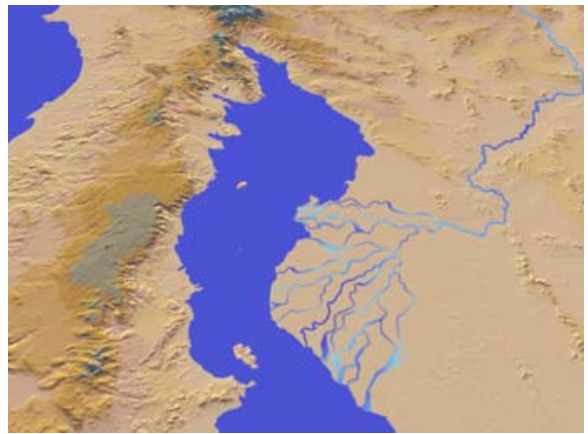

(b) Sediments from the Colorado River and Delta fill in the Gulf of California

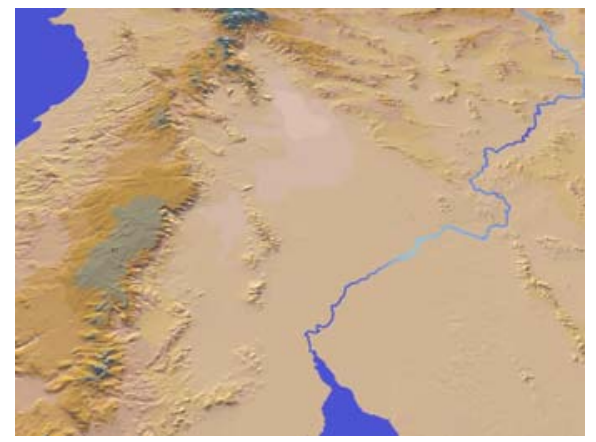

(d) A period when the basin was dry

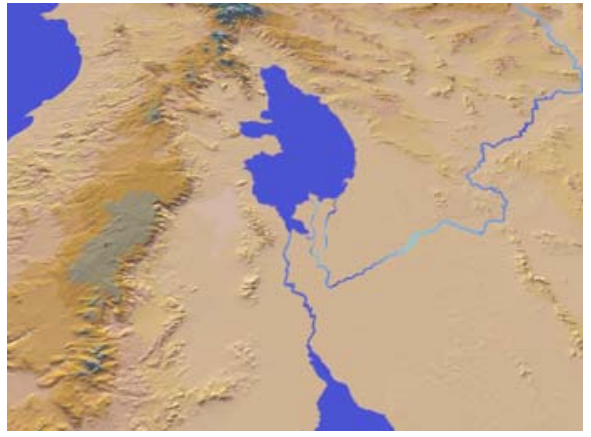

(f) Ancient Lake Cahuilla

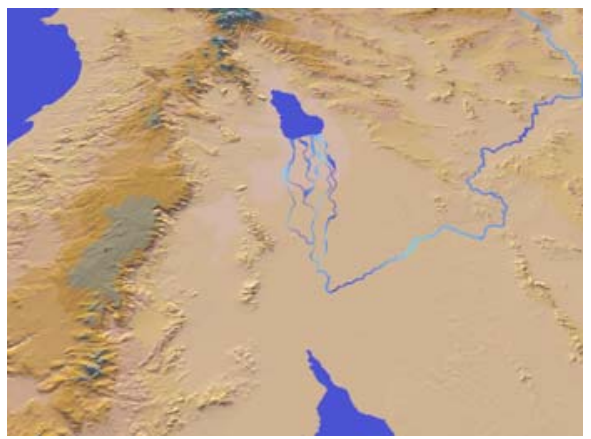

(h) 1905: Formation of contemporary Salton Sea

Figure 2.4: Processes leading to the formation of Lake Cahuilla and the Salton Sea 


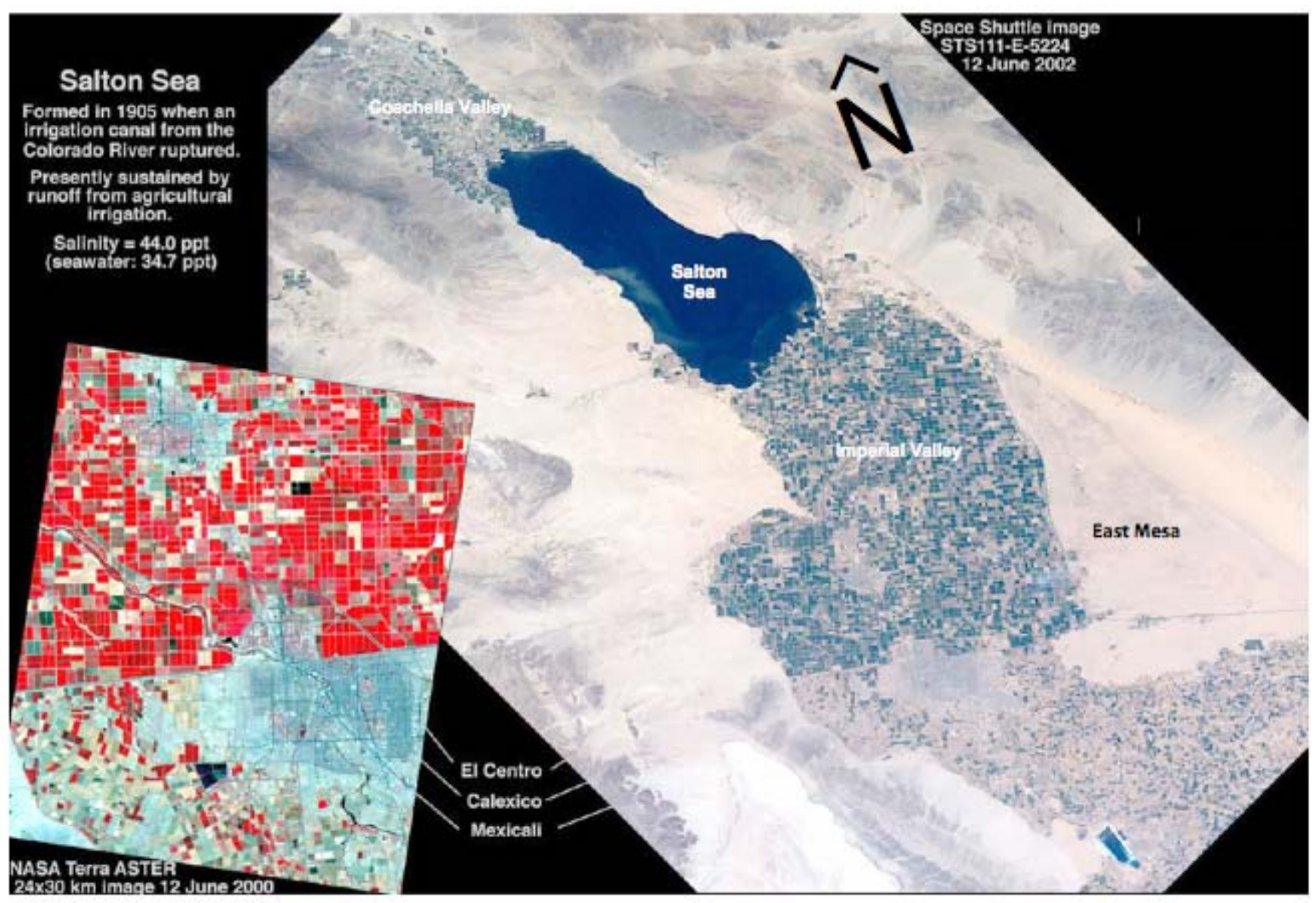

Figure 2.5: Satellite photo of the Salton Sea area showing irrigated agricultural regions in the Coachella Valley (north of Sea) in the Imperial and Mexicali Valleys (south of Sea). 


\subsection{Groundwater Occurrence Today}

Figure 2.6 shows a map of the Salton Sea area and the principal groundwater basins identified by the California Department of Water Resources (DWR, 2003) that are pertinent to this study. As discussed in DWR (2003), these basins refer to the "principal water bearing formations" in the shallower portions of the Salton Sea basin as a whole (up to 2,000 ft, or 610 $\mathrm{m}$, in depth), and do not correspond to deeper formations or water bearing deposits that extend to bedrock (as illustrated in Figures 2.2 and 2.3). The horizontal boundaries separating the individual basins in the figure do not necessarily represent physical barriers to flow, even though some correspond to fault lines or other subsurface restrictive structures. However, collectively, the union of these basins forms an extended shallow basin whose external perimeter (with the exception of those portions along the Mexican border and the Ogilby Valley basin) parallels much of the overlying watershed boundary, also shown in Figure 2.6, and can be considered to be of minimal thickness in these perimeter areas with no appreciable groundwater underflow. Characteristics of these basins are summarized in Table 2.3. Although not indicated, the groundwater basin as a whole extends across the US-Mexico border into the Mexicali Valley (Figure 2.3), similar to the overlying watershed boundary. Groundwater underflow occurs across the border, from Mexico, into the US.

It was previously mentioned that between 1.1 and 3 billion AF of groundwater could lie in storage in Salton Trough as a whole, to bedrock depths as far as 20,000 ft (6,100 m) below sea level (Imperial County, 1997). Although imprecise, this may serve as an approximate, upper bound measure of the groundwater volume or storage capacity of the basin. However, little of this water is considered recoverable or producible for viable uses because of high salinity, high temperature, land subsidence potential, or considerations of depth and formation permeability, and only a smaller fraction of that may be considered annually renewable.

The origin of groundwater currently found in the basin can generally be attributed to

- Ancient seawater associated with the Gulf of California when it extended north to Indio;

- Direct infiltration from the Colorado, New, and Alamo Rivers, both currently and previously when they discharged into Lake Cahuilla;

- Agricultural irrigation;

- Canal leakage;

- Recent and accumulated recharge from precipitation over the basin proper or concentrated around the basin perimeter from mountain runoff in streams or arroyos; and

- Aquifer storage operations in the Coachella Valley.

In this document, the entire groundwater system in the Salton Sea Trough will be distinguished in terms of a "shallow" system, ranging from the surface to approximately 2,000 ft $(610 \mathrm{~m})$ in depth, and a much "deeper" system, extending from the bottom of the shallow zone to the basement of the Trough. The transition between the shallow and deeper systems is typically associated with extensive low permeability materials that comprise the post-Brawley formation (Figure 2.3). Depending on the application, these systems are often thought to be separate and 
isolated, but may, in fact, be interconnected in some locations in terms of flow, recharge, or other processes.

\subsubsection{Shallow Groundwater System}

In general, the most active areas of groundwater production in the Salton Sea Basin tend to be confined to shallower system (Table 2.2, Figure 2.3). Shallow groundwater is easier to produce, more recent in age, and is can be of better quality than deeper basin groundwater. In the shallow system, groundwater flow is influenced by recharge and geologic features that include faults and the layered sedimentary structures associated with the Colorado River Delta and ancient seafloor deposits (Planert and Williams, 1995). The layered sediments tend to hydraulically separate deeper zones from shallow ones and isolate the generally small amount of annual recharge received in the basin. This is not to say that there is no groundwater movement in the deeper zones, nor any between the shallow and deeper zones, nor that shallow groundwater does not suffer from salinity (poor quality) problems typically found at greater depths. Because of the stratified nature of the shallow sediments, especially in the basin center, formation permeability can fluctuate widely over depth. As a result, confined and artesian can conditions occur in some areas (e.g., along mountain front locations in the Coachella Valley and in the central portions of the Imperial Valley), while perched conditions associated with springs and phreatophyte vegetation exist in other (eastern Imperial Valley) areas (see, e.g., Table 2.2 and DWR, 2003). Similar conditions can influence groundwater inflows to (or discharges from) the Salton Sea.

Geographically, the heaviest areas of groundwater use are in the northwest portion of the basin, in the Coachella Valley and surrounding areas (Table 2.2, Figure 2.6). Here, higher production tends to correlate with greater recharge along the mountain front locations to the west, more permeable geologic conditions conducive to pumping, better water quality, and greater population densities that generate higher water demands.

The estimated groundwater storage capacity in the (shallow) basins tabulated by DWR (2003; Figure 2.6 and Table 2.2) is between 81 and 87 MAF. The corresponding amounts of groundwater currently in storage, if estimated, are typically less. In general, the total amounts of groundwater in storage (and overall groundwater levels) in these basins have been steadily decreasing over the past 50 years as a result of increasing production and development. This is most evident in much of the Coachella Valley (Tyley, 1974) and Borrego Valley (Mitten et al., 1988), and in some parts of West Mesa area (Skriven, 1977). Water levels and groundwater in storage in the Imperial Valley and East Mesa have generally been steady or increasing over this period as a result of recharge from irrigation and canal seepage derived from imported Colorado River water (Loeltz et al., 1975).

\subsubsection{Groundwater Recharge}

Across the basin as a whole, the primary source of groundwater recharge is derived from imported water, either from the Colorado River or from the State Water project. Secondary sources of groundwater recharge are derived from natural sources related to direct precipitation, mountain front or stream flow runoff, or groundwater underflow across the bottom of the Salton Sea and the US - Mexico border. Collectively, these sources primarily contribute groundwater water to the "shallow" groundwater system (Table 2.3). Approximate recharge rates to selected groundwater areas in the Salton Sea Basin are shown in Table 2.4. 


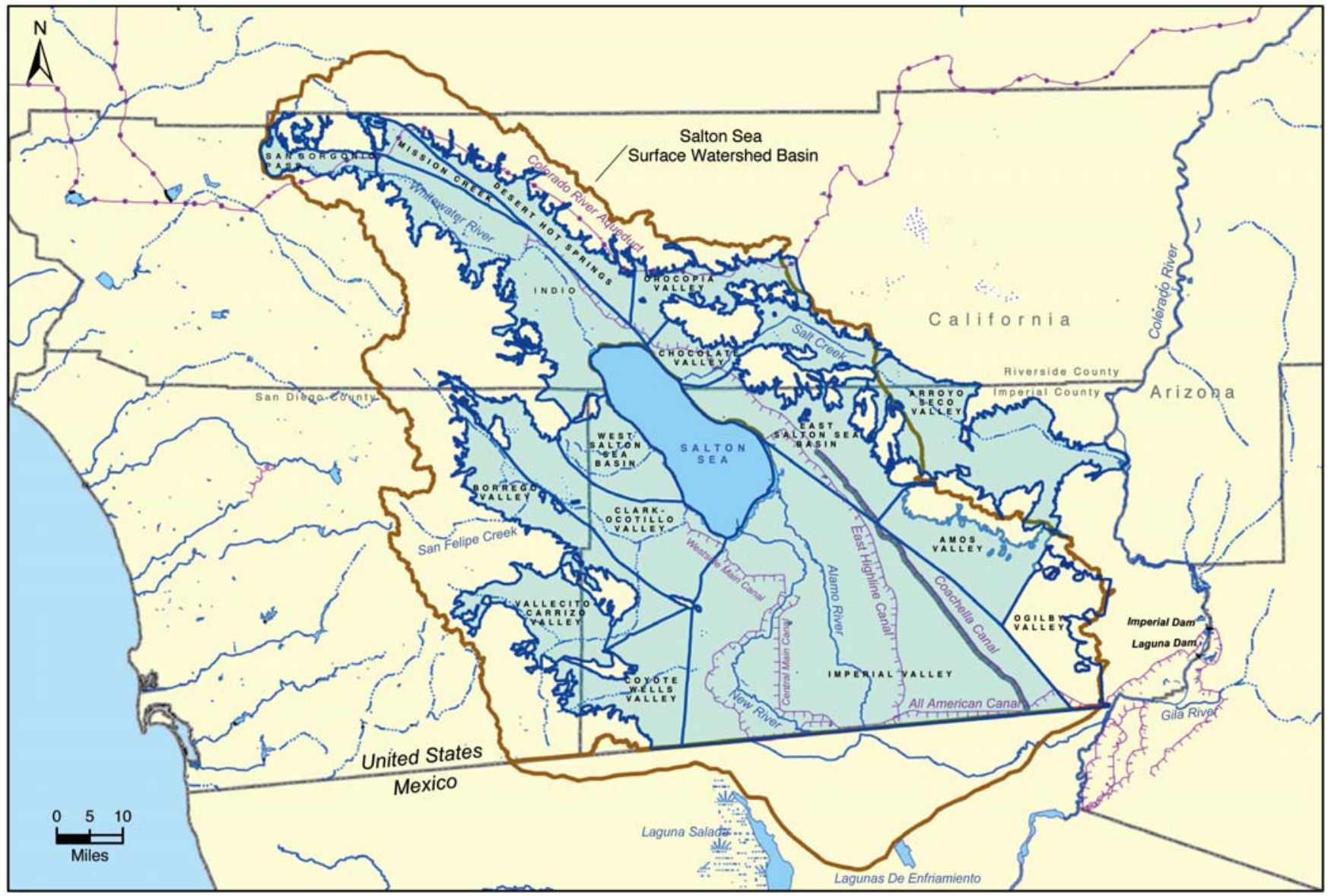

Figure 2.6: Close up map of the Salton Sea area showing the collection of California groundwater basins pertinent to this study (shaded and separated by thick blue lines), and various local rivers, streams, aqueducts, and canals (DWR, 2003). The brown curve corresponds to the regional watershed boundary. The thick gray line indicates the lined portion of the Coachella Canal. Note that the greater Coachella Valley groundwater basin includes the San Gorgonio, Indio, Mission Creek, and Desert Hot Springs sub basins shown in the figure and referred to in Table 2.3. 
Table 2.3: Summary characteristics of the shallow hydrologic basins in the Salton Sea area (Figure 2.5) and associated references, as described by DWR (2003), Appendix A. Natural groundwater discharges are confined to losses to the Salton Sea from perimeter basins and losses due to evapotranspiration, and basin-to-basin underflows (Section 2.3.5).

\begin{tabular}{|c|c|c|c|c|c|c|c|c|c|c|c|c|c|}
\hline \multirow{2}{*}{\multicolumn{2}{|c|}{$\begin{array}{c}\text { Groundwater Basin } \\
\text { (or Subbasin) } \\
\text { DWR ID number }\end{array}$}} & \multicolumn{2}{|c|}{ Water bearing formations } & \multirow{3}{*}{ 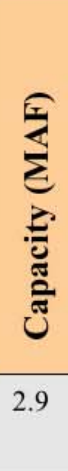 } & \multirow{2}{*}{ 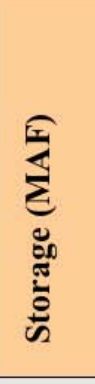 } & \multirow{2}{*}{ 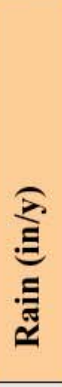 } & \multirow[t]{2}{*}{$\begin{array}{l}\text { Recharge } \\
\text { (rain and net } \\
\text { underflow) } \\
\text { (af/y) }\end{array}$} & \multirow[t]{2}{*}{$\begin{array}{l}\text { Trends } \\
\text { 1950s to } \\
1990 \text { s }\end{array}$} & \multicolumn{3}{|c|}{ Quality } & \multicolumn{2}{|c|}{$\begin{array}{c}\text { Domestic (D) } \\
\text { and } \\
\text { Municipal- } \\
\text { Irrigation (M) } \\
\text { Wells }\end{array}$} \\
\hline & & $\begin{array}{c}\text { Depth } \\
\text { range or } \\
\text { [thickness] } \\
\text { (ft) }\end{array}$ & Material & & & & & & $\begin{array}{l}\text { TDS range } \\
(\mathrm{mg} / \mathrm{L})\end{array}$ & $\begin{array}{l}\text { F range } \\
(\mathrm{mg} / \mathrm{L})\end{array}$ & Other & $\begin{array}{l}\text { Yield } \\
\text { range } \\
(\mathrm{gpm})\end{array}$ & $\begin{array}{l}\text { Depth } \\
\text { range } \\
\text { (ft) }\end{array}$ \\
\hline $\begin{array}{l}\text { Amos } \\
\text { Valley }^{10,15,33}\end{array}$ & $7-34$ & $0-550$ & Alluvium & & & & 250 rain & $\begin{array}{l}\text { Generally } \\
\text { declining }\end{array}$ & $\begin{array}{l}750 \text { to } \\
3,100\end{array}$ & 1 to 3.9 & B & $\begin{array}{l}50 \text { to } \\
100(\mathrm{M})\end{array}$ & \\
\hline $\begin{array}{l}\text { Chocolate } \\
\text { Valley }^{10,15}\end{array}$ & $7-32$ & $0-400$ & Alluvium & 1.0 & & & 200 rain & $\begin{array}{l}\text { Some } \\
\text { rising }\end{array}$ & $\begin{array}{l}460 \text { to } \\
24,500\end{array}$ & 0.6 to 60 & $\begin{array}{l}\mathrm{B}, 2.2 \\
\mathrm{mg} / \mathrm{L}\end{array}$ & & \\
\hline $\begin{array}{l}\text { Ocotillo-Clark } \\
\text { Valley }^{10,15,24}\end{array}$ & $7-25$ & $0-1,800$ & $\begin{array}{l}\text { Stream deposits } \\
\text { Alluvial fan deposits } \\
\text { Lake and eolian } \\
\text { deposits }\end{array}$ & 6.25 & & & $\begin{array}{l}2,300 \text { rain } \\
(-3 \text { wells })\end{array}$ & $\begin{array}{l}\text { Some } \\
\text { declining }\end{array}$ & $\begin{array}{l}560 \text { to } \\
4,656\end{array}$ & $\mathrm{~F}$ & $\mathrm{SO}_{4}$ & $\begin{array}{l}\text { To } 3,500 \\
\text { (M) }\end{array}$ & $\begin{array}{l}410 \\
\text { (D) to } \\
1,000 \\
\text { (M) }\end{array}$ \\
\hline $\begin{array}{l}\text { Arroyo Seco } \\
\text { Valley }^{10,15}\end{array}$ & $7-37$ & & Alluvium & 7.0 & & $\begin{array}{l}3 \text { to } \\
5\end{array}$ & 1,500 rain & $\begin{array}{l}\text { Generally } \\
\text { stable }\end{array}$ & $\begin{array}{l}300 \text { to } \\
2,450\end{array}$ & 0.1 to 5.2 & $\begin{array}{l}\mathrm{B}, \\
0.1 \text { to } 5.0 \\
\mathrm{mg} / \mathrm{L}\end{array}$ & & $\begin{array}{l}\text { To } 210 \\
\text { (M) }\end{array}$ \\
\hline $\begin{array}{l}\text { Coyote Wells } \\
\text { Valley }^{13-15,29}\end{array}$ & $7-29$ & $\begin{array}{l}100-300 \\
\text { To } 650\end{array}$ & $\begin{array}{l}\text { Holocene alluvium } \\
\text { Pleistocene alluvium }\end{array}$ & 1.7 & $\begin{array}{c}1.0 \\
(1973)\end{array}$ & & $\begin{array}{l}2,600 \text { rain } \\
(-1,900 \text { under }) \\
(-900 \text { wells })\end{array}$ & $\begin{array}{l}\text { Generally } \\
\text { declining }\end{array}$ & $\begin{array}{l}750 \text { to } \\
1,240 \\
\text { (shallow) } \\
300 \text { to } 450 \\
\text { (deep) }\end{array}$ & To 3.5 & & & \\
\hline $\begin{array}{l}\text { Orocopia } \\
\text { Valley }^{11,20,35-37}\end{array}$ & $7-31$ & $0-4,400$ & $\begin{array}{l}\text { Alluvium, lake } \\
\text { deposits }\end{array}$ & $\begin{array}{c}1.5 \\
\text { to } \\
6.25\end{array}$ & $\begin{array}{c}4.3 \\
(1981)\end{array}$ & $\begin{array}{l}\text { To } \\
4\end{array}$ & $\begin{array}{l}4,700 \text { rain } \\
0 \text { (net) under }\end{array}$ & $\begin{array}{l}\text { Water } \\
\text { table } 480 \\
\text { to } 800 \mathrm{ft}\end{array}$ & 254 to 665 & $>\mathrm{MCL}$ & $\begin{array}{l}\text { Some } \mathrm{Rn}, \\
\mathrm{U}>\mathrm{MCL}\end{array}$ & & \\
\hline
\end{tabular}

\section{(Continued)}




\begin{tabular}{|c|c|c|c|c|c|c|c|c|c|c|c|c|c|}
\hline$\cdots$ & & $\begin{array}{l}{[700]} \\
{[1,800]}\end{array}$ & $\begin{array}{l}\text { consolidated sand, } \\
\text { gravel, and boulders) } \\
\text { Lower (moderately } \\
\text { consolidated sand, } \\
\text { gravel, and boulders) }\end{array}$ & & & & $(-15,161$ wells $)$ & & & & $\begin{array}{l}\text { oune iva, } \\
\mathrm{Cl}, \mathrm{Fe}, \mathrm{B} \\
>\mathrm{MCL}\end{array}$ & & \\
\hline $\begin{array}{l}\text { East Salton } \\
\text { Sea }^{10,15}\end{array}$ & $7-33$ & $0-400$ & Alluvium & 0.36 & & & $\begin{array}{l}200 \text { rain } \\
(-6) \text { wells }\end{array}$ & $\begin{array}{l}\text { Generally } \\
\text { declining }\end{array}$ & $\begin{array}{l}356 \text { to } \\
51,632\end{array}$ & & & \multicolumn{2}{|c|}{$\begin{array}{l}\text { Generally } \\
\text { unsuitable water } \\
(\mathrm{D}, \mathrm{M})\end{array}$} \\
\hline $\begin{array}{l}\text { Imperial } \\
\underset{27}{\text { Valley }}\end{array}$ & $7-30$ & $\begin{array}{l}0-80 \\
{[\text { To } 450]} \\
{[60-280]} \\
{[\text { To } 1,500]}\end{array}$ & $\begin{array}{l}\text { Low permeability } \\
\text { (lake deposits) } \\
\text { Upper (alluvium) } \\
\text { Low permeability } \\
\text { aquitard } \\
\text { Lower (alluvium) }\end{array}$ & $14^{38}$ & & & $\begin{array}{l}250,000 \text { canal } \\
\text { seepage, irrigation } \\
173,000 \text { under } \\
(-270,000 \text { under }) \\
(-169,342 \text { streams })\end{array}$ & $\begin{array}{l}\text { Generally } \\
\text { stable }\end{array}$ & $\begin{array}{l}498 \text { to } \\
7,280\end{array}$ & & $\begin{array}{l}\sim 7,000 \\
\text { af/y } \\
\text { polluted } \\
\text { water } \\
\text { infiltrates } \\
\text { from } \\
\text { New } \\
\text { River }\end{array}$ & \multicolumn{2}{|c|}{$\begin{array}{l}\text { Generally } \\
\text { unsuitable water } \\
(\mathrm{D}, \mathrm{M})\end{array}$} \\
\hline $\begin{array}{l}\text { Vallecito- } \\
\text { Carrizo }^{7,10,15}\end{array}$ & $7-28$ & $0-300$ & Alluvium & 2.5 & & $\begin{array}{l}1 \text { to } \\
14\end{array}$ & Rain, underflow & $\begin{array}{l}\text { Rising } 10 \\
\text { to } 20 \mathrm{ft}\end{array}$ & $\begin{array}{l}250 \text { to } \\
1,270\end{array}$ & 0.1 to 5.5 & & $\begin{array}{l}260 \text { to } \\
2,500 \\
\text { (M) }\end{array}$ & \\
\hline $\begin{array}{l}\text { West Salton } \\
\text { Sea }^{10,15}\end{array}$ & $7-22$ & $0-545$ & Alluvium & & & $\begin{array}{l}1 \text { to } \\
8\end{array}$ & Rain & & $\begin{array}{l}2,000 \text { to } \\
16,600\end{array}$ & 1.2 to 6.2 & $\begin{array}{l}\mathrm{B}, 1.0 \text { to } \\
22.3 \\
\mathrm{mg} / \mathrm{L}\end{array}$ & $\begin{array}{l}400 \text { to } \\
540 \text { (M) }\end{array}$ & \\
\hline $\begin{array}{l}\text { Coachella } \\
\text { Valley: } \\
\text { Indio } \\
\text { subbasin } \\
25,26,34,39\end{array}$ & $\begin{array}{r}7-21 \\
.01\end{array}$ & {$[1,000]$} & $\begin{array}{l}\text { Holocene to } \\
\text { Pleistocene alluvium } \\
\text { (unconsolidated } \\
\text { poorly bedded coarse } \\
\text { sand and gravel); } \\
\text { Confined, unconfined } \\
\text { conditions }\end{array}$ & 29.8 & $\begin{array}{c}11.72 \\
(1974)\end{array}$ & & $\begin{array}{l}49,000 \text { rain (mean) } \\
61,000 \mathrm{ASR}^{39} \\
392,000 \text { total in } \\
(-465,000 \text { total out) }\end{array}$ & $\begin{array}{l}\text { Generally } \\
\text { declining, } \\
\text { from } \\
\text { pumping }\end{array}$ & $\begin{array}{l}300 \text { (native } \\
\text { water), but } \\
\text { higher with } \\
\text { Colorado } \\
\text { River } \\
\text { imports }\end{array}$ & & $\begin{array}{l}\mathrm{NO}_{3} \\
\text { plume }\end{array}$ & $\begin{array}{l}2 \text { to } \\
1,880 \\
\text { (M, } 872 \\
\text { wells) }\end{array}$ & $\begin{array}{l}47 \text { to } \\
1,420 \\
(\mathrm{M}, \\
927 \\
\text { wells) }\end{array}$ \\
\hline
\end{tabular}

\section{(Continued)}




\begin{tabular}{|c|c|c|c|c|c|c|c|c|c|c|c|}
\hline $\begin{array}{l}\text { Vussion Creek } \\
\text { subbasin,12,25,26, } \\
30,31\end{array}$ & & $\begin{array}{l}\text { that can } \\
\text { be } 7,000 \mathrm{ft} \\
\text { thick] }\end{array}$ & $\begin{array}{l}\text { poorly bedded coarse } \\
\text { sand and gravel; } \\
\text { some boulder to sand } \\
\text { silt clay mixtures) }\end{array}$ & & & (-12,639 pumping) & pumping & $\begin{array}{l}\text { deeper } \\
\text { parts of } \\
\text { formation } \\
\text { more saline }\end{array}$ & & wells) & $\begin{array}{l}\text { wells) } \\
50 \text { to } \\
1,000 \\
\text { (D, } \\
226 \\
\text { wells) }\end{array}$ \\
\hline $\begin{array}{l}\text { Coachella } \\
\text { Valley: } \\
\text { Desert Hot } \\
\text { Springs } \\
\text { subbasin }\end{array}$ & $\begin{array}{r}7-21 \\
.03\end{array}$ & {$[700]$} & $\begin{array}{l}\text { Holocene to } \\
\text { Pleistocene alluvium } \\
\text { (unconsolidated } \\
\text { poorly bedded coarse } \\
\text { sand and gravel) } \\
\text { Generally unconfined }\end{array}$ & $\begin{array}{c}4.1 \\
\text { over } \\
1000 \\
\mathrm{ft}\end{array}$ & $\begin{array}{l}0.17 \\
\text { for } \\
\text { first } 20 \\
\mathrm{ft} \text { of } \\
\text { aquifer } \\
(1964)\end{array}$ & $\begin{array}{l}2,900 \text { tributary } \\
\text { runoff }\end{array}$ & $\begin{array}{l}\text { Some } \\
\text { declining, } \\
\text { but } \\
\text { generally } \\
\text { under } \\
\text { developed }\end{array}$ & $\begin{array}{l}800 \text { to } \\
1,000\end{array}$ & $\begin{array}{l}\text { High T } \\
\left(118^{\circ} \mathrm{F}\right) \\
\text { near } \\
\text { Mission } \\
\text { Creek } \\
\text { fault }\end{array}$ & $\begin{array}{l}5 \text { to } \\
2,500 \\
(\mathrm{M}, 18 \\
\text { wells) }\end{array}$ & $\begin{array}{l}192 \text { to } \\
520 \\
\text { (M, 15 } \\
\text { wells) } \\
300 \text { to } \\
845 \\
\text { (18 } \\
\text { wells) }\end{array}$ \\
\hline $\begin{array}{l}\text { Coachella } \\
\text { Valley: } \\
\text { San Gorgonio } \\
\text { Pass } \\
\text { subbasin } \\
18,19,2,5,6,12,\end{array}$ & $\begin{array}{r}7-21 \\
.04\end{array}$ & $\begin{array}{l}\text { [often } \\
\text { above } \\
\text { water } \\
\text { table] } \\
\text { to } 2,000\end{array}$ & $\begin{array}{l}\text { Holocene to } \\
\text { Pleistocene alluvium } \\
\text { (gravel, sand; some } \\
\text { clay, silt) } \\
\text { Pliocene to } \\
\text { Pleistocene age San } \\
\text { Timoteo Formation } \\
\text { (sandstone, gravel, } \\
\text { interbedded clays) }\end{array}$ & $\begin{array}{l}2.2 \\
\text { to } \\
2.7\end{array}$ & $\begin{array}{c}1.4 \\
(1987)\end{array}$ & $\begin{array}{l}(-9,000 \text { undeflow }) \\
(-7,488 \text { wells }) \\
2,100 \text { rain and } \\
\text { streamflow }\end{array}$ & $\begin{array}{l}\text { Some } \\
\text { declining, } \\
\text { some } \\
\text { steady }\end{array}$ & 106 to 205 & & $\begin{array}{l}1,000 \\
\text { (one } \\
\text { report) }\end{array}$ & \\
\hline
\end{tabular}

BCVWD (1995), ${ }^{2}$ Bloyd (1971), ${ }^{3}$ Borrego Water District (2000), ${ }^{4}$ Borrego Water District (2002), ${ }^{5}$ Boyle Engineering Corporation (1988), ${ }^{6}$ Boyle Engineering Corporation (1993), ${ }^{7}$ Brown (1923), ${ }^{8} \mathrm{CVWD}(2000 \mathrm{a}),{ }^{9} \mathrm{CVWD}$ (2000b), ${ }^{10} \mathrm{DPW}$ (1954), ${ }^{11} \mathrm{DWR}(1963),{ }^{12} \mathrm{DWR}(1964),{ }^{13} \mathrm{DWR}(1967),{ }^{14} \mathrm{DWR}(1973),{ }^{15} \mathrm{DWR}(1975),{ }^{16} \mathrm{DWR}(1979),{ }^{17} \mathrm{DWR}(1984),{ }^{18} \mathrm{DWR}(1987),{ }^{19} \mathrm{Frick} \mathrm{C} .(1921)$,

${ }^{20}$ LeRoy Crandall and Associates (1981) ${ }^{21}$ Loeltz et al. (1975), ${ }^{22}$ Mitten et al. (1988), ${ }^{23}$ Montgomery Watson Inc. (1995), ${ }^{24}$ Moyle $(1982),{ }^{25}$ MSWD (2000), ${ }^{26} \mathrm{Planert}$ and Williams $(1995)$, ${ }^{27}$ Setmire (1979),

${ }^{28}$ SGPWA (2001), ${ }^{29}$ Skrivan (1977), ${ }^{30}$ Slade (1981), ${ }^{31}$ Slade and Associates (2000), ${ }^{32}$ Swain (1978), ${ }^{33}$ Tetra Tech, Inc. (1999), ${ }^{34}$ Tyley (1974), ${ }^{35}$ URS Corporation (2000), ${ }^{36}$ Wilson and Owen-Joyce (1994),

${ }^{37}$ Owen-Joyce and Wilson (2000), ${ }^{38}$ to $20,000 \mathrm{ft} \mathrm{depth},{ }^{39} \mathrm{ASR}$ volumes reached 228,000AF in 2005-2006 (CVWD, 2006) 
Imported water supports agriculture in both the Imperial and Coachella Valleys $(525,000$ and 100,000 acres, respectively) as well as Aquifer Storage and Recovery (ASR) operations in the Coachella Valley (Planert and Williams, 1995; CVWD, 2000a,b; 2006). In agricultural areas, recharge may occur as a result of irrigation and drainage network losses or from leakage underneath imported water canals.

The magnitude of irrigation-based recharge may be estimated for the Coachella Valley and Imperial Valley using information in DWR (2003) and related sources. In 1999, for example, in the Coachella Valley, total aquifer inputs $(392,000 \mathrm{AF})$ minus ASR inputs $(61,000 \mathrm{AF})$ and precipitation inputs (16,800 AF for 1999) yields 314,000 AF (CVWD, 2000a). Because the total outflows $(465,800 \mathrm{AF})$ exceeded the total inputs, additional ASAR activity reflected in Table 2.4 has been developed since 1999, relying upon imported water both from the Coachella Canal and the State Water Project (CVWD, 2006). As a result, current ASR inputs have risen. Irrigation discharges into the Salton Sea (through the Whitewater River or other drainage networks) totals 81,765 AF/y (Table 2.1).

Table 2.4. Selected recharge rates to groundwater in the Salton Sea Basin (approximate)

\begin{tabular}{|c|c|c|}
\hline Source & Subtotal $\left(\mathrm{AF} / \mathbf{y}^{1}\right)$ & Total (AF/y) \\
\hline Coachella Valley irrigation $^{2}$ & & 314,000 \\
\hline Coachella Valley ASAR ${ }^{2,3}$ & & 228,520 \\
\hline Whitewater River & 165,554 & \\
\hline Dike 4 & 3,968 & \\
\hline Mission Creek & 24,723 & \\
\hline Martinez Canyon & 775 & \\
\hline Coachella Valley aquifer underflow ${ }^{4}$ & & 366 \\
\hline Imperial Valley irrigation $^{5}$ & & 0 to 250,000 \\
\hline Imperial Valley river and canal leakage $^{6}$ & & 127,206 \\
\hline All American Canal leakage & 94,206 & \\
\hline Coachella Canal & 26,000 & \\
\hline New River & 7,000 & \\
\hline Precipitation over all groundwater basins ${ }^{7}$ & & 75,000 \\
\hline OVERALL TOTAL & & 995,092 \\
\hline $\begin{array}{l}\text { One acre foot }(\mathrm{AF})=1,233.5 \mathrm{~m}^{3} \text { or } 1.23 \times 10^{-6} \mathrm{~km}^{3} \\
{ }^{2} \mathrm{CVWD}(2006) \text { data here more current than } \mathrm{DWR}(2003 \\
\mathrm{ASAR}=\text { Aquifer Storage and Recovery } \\
{ }^{4} \text { Table } 2.1 \text {, after Weghorst }(2001) \\
\text { Tables } 2.3,2.5 \text {, and related discussions about the range } \\
\text { Table } 2.2 \text { and related discussions } \\
\text { Table } 2.3 \text { and Appendix A; US areas only }\end{array}$ & $\begin{array}{l}\text { Table } 2.3 \\
\text { e values }\end{array}$ & \\
\hline
\end{tabular}

In the Imperial Valley, recharge arising from irrigation and canal leakage has been estimated in aggregate to be close to 250,000 AF/y (DWR, 2003; Table 2.3). This is concentrated in the heavily irrigated areas (525,000 acres) south of the Salton Sea (Figure 2.5). This particular recharge value may be influenced by the effectiveness of the drainage systems in the Imperial Valley, as well as artesian groundwater conditions observed in these areas. 
As an alternative, we may also attempt to estimate the net recharge in the Imperial Valley due to irrigation from a mass balance formulated around our knowledge of imported water, discharged water, and water lost to evapotranspiration in the irrigated region of the Imperial Valley:

\section{(2.1) Net Irrigation Recharge Rate Applied Water Rate - Discharged Water Rate - ET}

Table 2.5 summarizes several approximate scenarios under which the net recharge rate in (2.1) can be evaluated. These are based upon the assumption that the AAC flow rate before the East Highline Canal represents the "Applied water" rate and that the net inflow from the to the Salton Sea from the US is equal to the "Discharged water" rate. Loses (or potential losses) from evapotranspiration are based upon a range of ET rates taken from the reports of Reclamation $(1993,1994)$ or an aggregate value derived in the analysis in Appendix A, Section A.2.4 (preferred here). Negative net recharge values may occur if artesian groundwater discharges contribute to ET; otherwise, the net recharge values should be considered zero. Variability in these results is particularly affected by uncertainty in (i) the ET estimates, (ii) integrity of the tile drainage system, and (iii) the potential for artesian conditions to contribute to the observed Salton Sea discharges.

Table 2.5. Estimates of net irrigation-based recharge rate in the Imperial Valley

\begin{tabular}{|c|c|c|c|}
\hline \multicolumn{2}{|l|}{ Component } & Subtotal (AF/y) & Total (AF/y) \\
\hline \multicolumn{2}{|l|}{ AAC imports before EHC } & & $2,849,981$ \\
\hline \multicolumn{2}{|l|}{ Discharge into Salton Sea ${ }^{2}$} & & $1,025,504$ \\
\hline \multicolumn{2}{|l|}{ Alamo River (IID) } & 641,758 & \\
\hline \multicolumn{2}{|l|}{ New River (IID) } & 289,332 & \\
\hline \multicolumn{2}{|l|}{ IID direct } & 94,414 & \\
\hline \multicolumn{4}{|l|}{ Potential ET $_{\mathrm{c}}^{3,4}$} \\
\hline \multirow[t]{4}{*}{ ET Loss Factor $=$} & $3 \mathrm{ft} / \mathrm{y}$ & $1,575,000$ & \\
\hline & $3.85 \mathrm{ft} / \mathrm{y}^{5}$ & $2,021,250$ & $2,021,250$ \\
\hline & $4 \mathrm{ft} / \mathrm{y}$ & $2,100,000$ & \\
\hline & $5 \mathrm{ft} / \mathrm{y}$ & $2,625,000$ & \\
\hline \multicolumn{2}{|l|}{ Net Recharge Rate ${ }^{6}$} & Subtotal (AF/y) & Total (AF/y) \\
\hline \multirow[t]{4}{*}{ ET Loss Factor $=$} & $3 f t / y$ & 249,477 & 249,477 \\
\hline & $3.85 \mathrm{ft} / \mathrm{y}^{5}$ & $-196,773$ & $\mathbf{0}$ \\
\hline & $4 \mathrm{ft} / \mathrm{y}$ & $-275,523$ & \\
\hline & $5 \mathrm{ft} / \mathrm{y}$ & $-800,523$ & \\
\hline
\end{tabular}

${ }^{1}$ Table 2.2, based upon Reclamation (1994), assumed equal to "Applied Water Rate"

${ }^{2}$ Table 2.1, based upon Weghorst (2001), assumed equal to "Discharged Water Rate"

${ }^{3}$ Potential ET loss $\sim$ ET loss factor $(\mathrm{ft} / \mathrm{y}) \times 525,000$ acres, using ET factors $(3,4$, or $5 \mathrm{ft} / \mathrm{y})$ similar to Reclamation $(1993,1994)$.

${ }^{4}$ Potential ET loss $\sim$ ET loss factor $(\mathrm{ft} / \mathrm{y}) \times 525,000$ acres, using ET factor $(3.85 \mathrm{ft} / \mathrm{y})$ from equation (A.14), Appendix A

${ }^{5}$ Preferred

${ }^{6}$ Equation (1). Negative net recharge values may occur if artesian groundwater (discharges) contributes to ET; otherwise, the net recharge values are considered zero. 
The average, annual distribution of precipitation across the basin, as derived from a process outlined in Appendix A, is shown in Figure 2.7. The maximum precipitation amounts are clearly clustered along the western and northwestern mountain fronts surrounding the basin, and occur primarily in the winter. The largest amounts are as high as $35 \mathrm{in}(900 \mathrm{~mm})$ and occur in the vicinity of Mt. Gorgonio, the highest peak in Southern California.

The integrated average annual precipitation accrued over the entire watershed, as approximated in Appendix A, is close to 2.4 MAF. Yet only a fraction of this will end up as aquifer recharge in the central groundwater basins. According to the data compiled in Table 2.2 (DWR, 2003), the net precipitation-based groundwater recharge over the US side of the basin is close to 75,000 AF/y, and much of this is concentrated in the Coachella Valley. These data are roughly consistent with newer recharge assessments made in Appendix A.

\subsubsection{Canal and River Leakage}

As discussed previously, the All American (AAC) and Coachella Canals (CC) are the principal channels that import Colorado River water into the Salton Sea basin, and they bound the largely undeveloped East Mesa area in Imperial County (Figure 2.1). Numerous other secondary canals, laterals, and rivers serve to distribute this water to agricultural and urban uses in the Imperial and Coachella Valleys. These canals were originally constructed in the 1940s as unlined channels. In 1979, a 49-mile long portion of the CC, beginning at its diversion point at the AAC, was reconstructed as a concrete-lined channel to reduce seepage losses (Figure 2.1). The next 37 miles of the CB, paralleling the Salton Sea, remain unlined, while the final 37 miles extending into the Coachella Valley, are also lined. The 81-mile long AAC has remained unlined over its entire length since its construction. Reconstruction of a lined 23-mile long section between Pilot Knob and Drop 3 is now underway.

According to Loeltz et al. (1975), seepage losses from the AAC and CC between 1950 and 1967 amounted to 215,000 AF/y on average, although significant decline in the year-to-year values occurred over this period. More recently, canal flow rate data tabulated by Reclamation $(1993,1994)$ indicate aggregate losses of 4.9 MAF from the All American Canal between 1948 and 1988 (or approximately 123,000 AF/y on average) and 4.8 MAF from the Coachella canal between 1948 and 1979 (or 155,000 AF/y on average). The apparent losses for the canals gradually declined between the early and later years, a process deemed typical for unlined impoundments where seepage is controlled by percolation into unsaturated sediments. Reanalysis of the current loss rates in the AAC and the remaining unlined portions of the CC were developed by Reclamation $(1993,1994)$ and showed adjusted losses of 94,206 AF/y for the AAC and 26,000 AF/y for the CC (Table 2.2).

Another source of groundwater recharge occurs along the lower reaches of the New River, near Calexico. Montgomery Watson (1996) has estimated losses of 7,000 AF/y from the river, although this water is very poor in quality.

Canal leakage has generally led to groundwater mounding (aquifer storage) underneath both the Coachella and All American Canals. The mound under the All American Canal extends across both sides of the US-Mexico border and appears to have reached a steady state in terms the associated increase in groundwater storage. The mound under the Coachella Canal led to groundwater discharges into the East Highline Canal (4,000 AF/y, Tetra Tech, 1999) that were later reduced as a result of the canal being lined. The increase in groundwater storage in East Mesa through 1979 was originally estimated to be 700,000 AF for the area between the 
Coachella Branch and the East Highline Canal (Le Roy Crandall and Associates 1983). More current analyses have placed this increase closer to 1.5 MAF by taking into account additional factors such as storage in the Mexican side of the mound (Tetra Tech, 1999). The difference between storage increases and cumulative losses from seepage have been attributed to evapotranspiration by phreatophyte vegetation near the canals, discharges into agricultural drains and canals, and underflows into the Imperial and Mexicali Valleys (Tetra Tech, 1999).

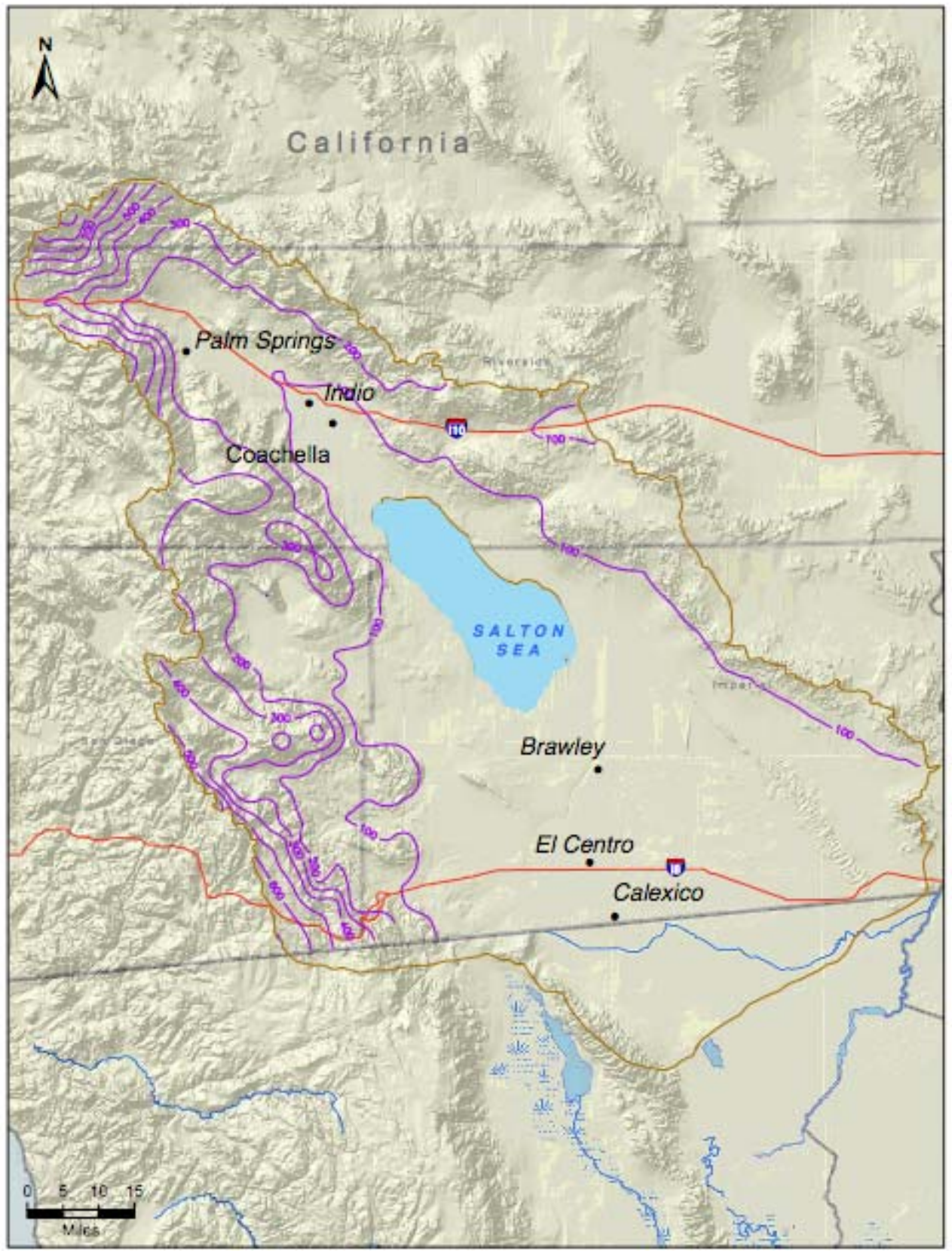

Figure 2.7: Contours of the mean annual precipitation $\Delta W_{P}$ (in mm) over the Salton Sea Basin, as derived from accrued rainfall data between 1971 and 2000 provided by the PRISM Group, Oregon State University, http://www.prismclimate.org (Appendix A). 


\subsubsection{Natural Groundwater Discharges} include

Across the basin as a whole, the primary modes of natural groundwater discharge

- Irrigation related discharges into drainage networks, including some deeper artesian flows, primarily in the Imperial Valley and Coachella Valley agricultural areas;

- Underflows into the Salton Sea from perimeter groundwater basins (e.g., Chocolate Valley, West Salton Sea, and Coachella Valley basins, DWR, 2003; Weghorst, 2001);

- Natural cold and hot water springs along the western basin perimeter (e.g., San Felipe Creek), eastern basin perimeter (e.g., Dos Palmas Springs), and San Andreas Fault zone;

- Wetland area discharges derived from shallow, mounded groundwater near the All American and Coachella Canals (Figure 2.8 and Reclamation, 1993, 1994); and

- Collateral evapotranspiration of shallow groundwater in some irrigated areas.

The wetland areas in (iv) above are manifested primarily by phreatophyte vegetation (e.g., invasive Salt cedar), largely between Drops 3 and 4 of the All American and in areas lying between the Coachella Canal and the Salton Sea between Niland and Dos Palmas Spring (Figure 2.8). The canals in these areas are or remain unlined.

\subsubsection{Deeper Groundwater System}

The existence of groundwater below the shallow sedimentary deposits in the basin - that is, between the deposits and deeper bedrock ( 2,000 to 20,000 ft depth range, or 610 to $6,100 \mathrm{~m}$, Figure 2.3) - can be attributed, in part, to its original association with ancient overlying seawater (Figure 2.4). In a basic sense, the deepest waters are those most typically associated with high salinity and high temperatures caused by magma intrusions underlying the Salton Trough. There are very few, if any, water supply wells that penetrate beneath 2,000 feet $(610 \mathrm{~m})$ in the basin, probably because of their expense and because of concerns about the poor water quality at these depths. The few wells that do penetrate into deeper formations typically support geothermal energy production.

It is generally assumed that lower permeability materials in or below the sedimentary deposits - especially in the basin center - impede groundwater flow between the shallow and deeper systems. This would seem to suggest that there are no significant modes for groundwater to recharge to or discharge from great depths and that deep groundwater is very old and isolated from recent climatic and shallower hydrologic influences.

The large geothermal temperatures at the basin bottom are believed to generate buoyancy-driven circulation cells that move warmer waters upward and draw cooler waters down, as mediated or bounded by low permeability "cap rock" barriers in some or all of the shallow sediment areas. As part of this circulation, it has been suggested that flow pathways may connect shallow recharge areas around the basin perimeter to the deeper hydrothermal system although any real recharge that occurs in this fashion would have to be balanced by a corresponding discharge out of the deep, and otherwise closed system, possibly through high permeability gaps in the shallower sediments (Dutcher et al., 1972). In the present day, hot geothermal waters are known to reach the surface in some locations, primarily in the numerous hot springs and mud pots along fault lines where fault-created hydraulic pathways may be more prevalent, suggesting that some groundwater exchanges between the deep and shallow systems 
exist to some degree. This has likely been an ongoing process for thousands of years, potentially serving - over the time line of the ancient Gulf, Lake Cahuilla, and shallow sediment deposition - to mix older waters with new, deeper waters with shallow, and saline waters with fresh, all to the extent that high permeability pathways allow.

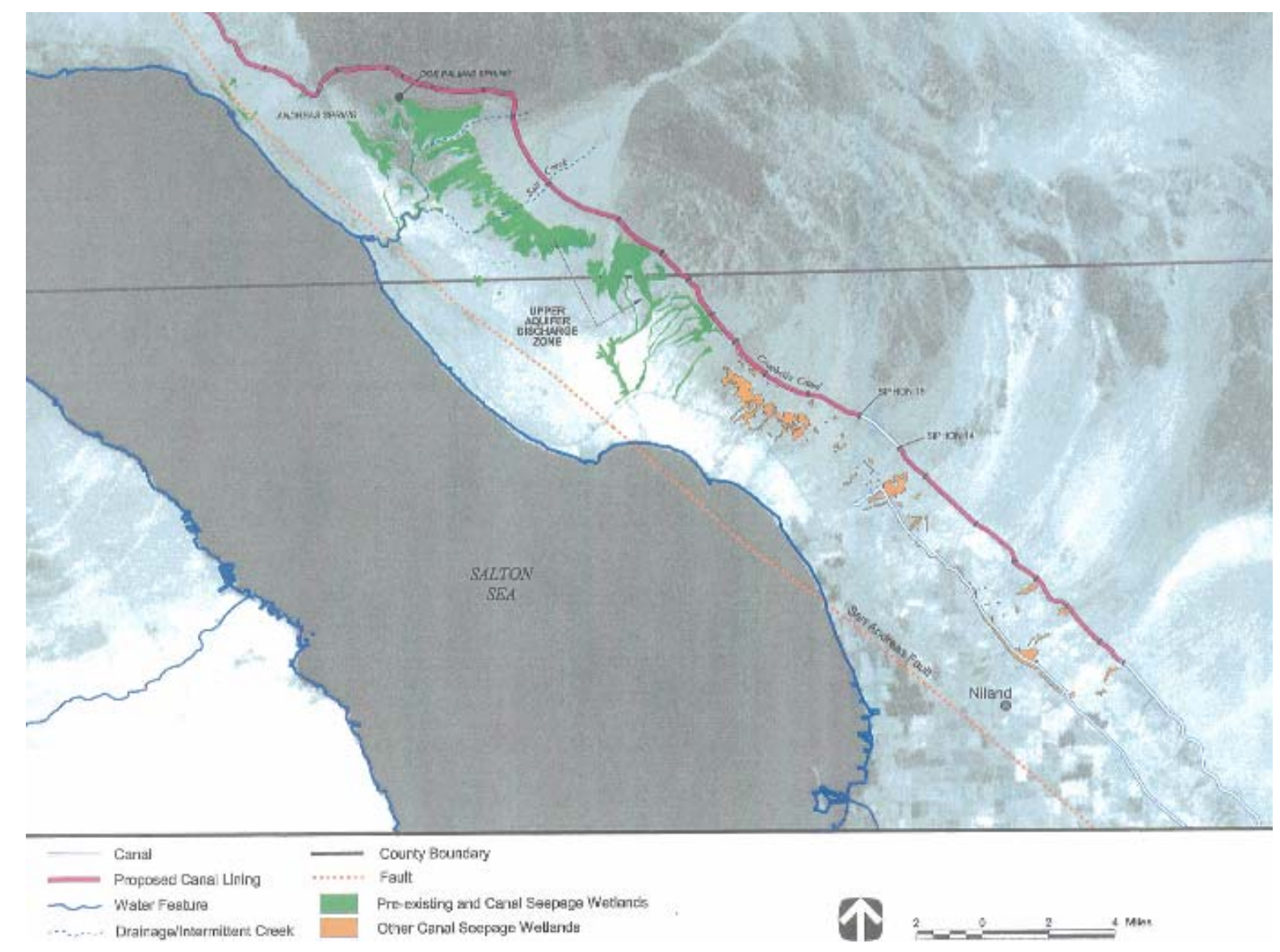

Figure 2.8: Discharge and phreatophyte wetland areas associated with water losses from unlined (in red) portions of the Coachella Canal (reproduced from Tetra Tech, 1999). 


\subsection{Groundwater Production}

\subsubsection{Background}

Groundwater production in the Salton Sea basin has been largely confined to the shallower water bearing formations reviewed in Table 2.3 and DWR (2003). Geographically, the heaviest areas of groundwater use are in the northwest portion of the basin, in the Coachella Valley groundwater basin and surrounding areas where groundwater is produced in moderate to large quantities for municipal and some agricultural purposes (Table 2.3, Figure 2.6). These areas roughly overlap a portion of the basin that receives the most precipitation (Figure 2.7) and greatest groundwater recharge (Appendix A). Water supplies in this area are supported by imports from the Colorado River delivered through the Coachella Canal and from the State Water Project. Imported water is also used to support aquifer storage and recovery operations (Table 2.4).

In the southern portions of the basin, and the Imperial Valley in particular, groundwater is also produced for domestic and agricultural purposes, but in much smaller quantities. This is due to limited groundwater producibility and quality conditions in much of the Imperial Valley (Table 2.3) and the far greater availability of imported Colorado River water to meet most largescale demands ${ }^{4}$. Nevertheless, numerous wells in the basin fill deposits along the valley perimeter and in the West and East Mesas can and do produce large volumes of potable water. These wells take advantage of better permeability conditions in the basin perimeter areas and access to (most likely younger) groundwater unaffected by salinity or other agricultural pollution sources. Agricultural water is also extracted from wells located on the Mexican side of the border, notably from the groundwater mound underlying the All American Canal.

In terms of producing "new" groundwater for a new or expanded use, there will be, ultimately, a number of considerations related to the availability components (Section 1.1) that need to be addressed. These include

- What quantity of water is desired, at what quality, and for how long?

- Can such groundwater be economically produced and sustained over time by natural or artificial replenishment?

- Will there be deleterious impacts to other groundwater users, surface facilities, or the broader environment?

- Will there be limitations on this production that occur over time, either from availability, impact, or quality reasons?

Some qualitative information on producing new groundwater in the shallow and deeper systems, as based upon the information above, is given below.

\subsubsection{New Groundwater Production from the Shallow System}

In general, it would appear that two areas could potentially support new and viable

\footnotetext{
${ }^{4}$ Similar conditions exist in the Mexicali Valley where agriculture is heavily supported by water imported through local aqueducts connected to the Colorado River.
} 
(shallow) groundwater production in the southern portion of the Salton Sea basin. These include

- Mountain front areas along the western perimeter of the basin, south of the Coachella Valley and extending into the West Mesa area (e.g., Table 2.3 and Appendix A); and

- The groundwater mound underlying the All American or Coachella Canals.

Production of additional groundwater in the central portion of the Imperial Valley would appear to be limited because of low permeability or water quality constraints. Lower permeability is derived from the lakebed and delta sedimentary deposits in this area. Because much of the groundwater in this portion of the basin is derived from agricultural recharge, it is not likely to be any better in its quality than water discharged directly through agricultural drains.

The mountain front areas south of the Coachella Valley include portions of the West Salton Sea, Ocotillo-Clark Valley, Borrego Valley, Vallecito-Carrizo, and Coyote Wells Valley groundwater basins shown in Figure 2.6. This concept is based upon the observation of small to moderate precipitation amounts in the western mountains bounding the basin and their potential to support recharge in the associated runoff areas in nearby Salton Sea groundwater basins (Figure 2.7; Appendix A). An examination of the data and references compiled in Table 2.3 and in Appendix A indicates that although precipitation-based recharge rates in the western perimeter areas are not large, they are, with the exception of the Coachella Valley, among the highest in the basin as a whole. Most of these basins include a number of highly productive wells, yet have, in general, stable to declining water level trends that can be correlated to steady increases in local production over the past half century. Notably, the Vallecito-Carrizo basin has been showing rising levels of groundwater to the tune of 10 to 20 feet over the same period. It has an estimated storage capacity of 2.5 MAF yet a recharge rate of only 2,000 AF/y. As discussed in Appendix $A$, the estimated recharge rate would be much higher if runoff from the western mountain fronts were taken into account in the estimation process, but would certainly be bounded by the $\sim 60,000 \mathrm{AF} / \mathrm{y}$ precipitation rate that contributes to runoff and recharge in the immediate basin watershed area. This suggests that increased rates of renewable groundwater production in these areas may not be sustainable at large levels, although better estimates of recharge that incorporate runoff from higher terrain are warranted.

As has been recognized elsewhere, groundwater in the mounded areas underlying the East Mesa would appear to be another available source of new water for use in southern part of the basin region, at least in terms of water volume (e.g., Le Roy Crandall and Associates 1983; Tetra Tech, 1999). Nevertheless, factors related to water quality degradation, formation permeability, sustainability, and legal and physical accessibility would have to be considered further in order to exploit this as a water supply. Certainly, as natural recharge is very low in the East Mesa area, any sustained production of new groundwater (i.e., in excess of increased storage mentioned above) would have to be realized through a continued or formally codified aquifer storage and recovery (ASR) operation, utilizing excess Colorado River water in wet years, much in the same way as is being pursued in the Coachella Valley and elsewhere in Southern California (Bloyd, 1971; Tyley, 1973; Mallory et al., 1980; MWD/BLM, 1999; and Montgomery Watson, 2000).

Elsewhere in the Imperial Valley, and with exception of the water mounding underneath the water canals, the data in Table 2.3 indicate that there appears to be no other potential source of new groundwater in the shallow groundwater system. This is based upon a lack of sufficient annual precipitation-based recharge, poor water quality conditions, poor water productivity 
conditions, or decreasing water level trends related to recent production trends.

\subsubsection{New Groundwater Production from the Deeper System}

There are very little data that would clarify the potential viability of producing new groundwater from intermediate or lower depths in the deeper system for use in domestic or agricultural sectors. These depths are typically not considered as permeable or accessible as those in the shallow system nor are they considered to contain water of sufficient quality for domestic or agricultural uses. They are also not considered in statewide groundwater assessments that pertain to the Salton Sea basin, as summarized in Table 2.3.

Should "positive" permeability and water quality conditions exist in some parts of the deeper system that would support groundwater production, additional considerations with regard to sustainability would have to be considered. These would include, for example,

- Developing some understanding of flow pathways from shallower depths or other deep locations that would serve to replenish water removed from these areas, and/or

- Determining to what extent water would be produced out of compressible storage.

In the first case, should production commence in a viable location, there would be potential impacts to water production in nearby shallower wells. In the second case, water production could lead to subsidence, which could affect structures and/or canals on the surface. Subsidence related to deep groundwater production associated with geothermal energy production has been documented in the East Mesa (e.g., Massonnet et al., 1997).

\subsubsection{Wells, production data, and related aquifer characterization information}

Outside of the references and generalized information in Table 2.3, there are no integrated, basin-wide compendia or inventories of water wells, associated construction details, production, test, or water quality data, and related lithologic and hydrogeologic information in the public domain that might collectively be used to forecast the future producibility and quality of groundwater in the basin. Such information does exist, of course, albeit in scattered locations, formats, quality, and availability, along with other pertinent data related to climate, land use, surface water conditions, and so forth. There is also a sizeable collection of reports and interpretive documents related to regional and local geology, hydrology, and water quality, including many focused on the Colorado River, geothermal energy, canals and irrigation, and ecology.

Within the Imperial Valley itself, for example, the geohydrologic assessment of Loeltz et al. (1975) reviews a modest group of wells and springs in the Western, Central, and Eastern portions of the valley, tabulating selected physical or construction details (e.g., ownership, use, depths, water levels, production rates), lithology data (e.g., driller's logs), and chemical analyses of water sampled from wells (e.g., trace minerals, TDS). For reference and future comparison, a brief summary of the information in Loeltz et al. (1975) is provided below. Figure 2.9 shows locations of a selection of these wells.

- Physical or construction details were provided for 208 wells or springs $(46,102$, and 60 in the Western, Central, and Eastern Imperial Valley, respectively). The majority of the wells were limited to depths within 1,000 ft of the ground surface, with singular exceptions reaching 2,500 ft (for a well in the East) and 3,000 ft (for a well in the West). Production rates were generally very low in Central Valley 
wells (all less than 100 gpm), but much higher in many of the Western and Eastern Imperial Valley wells (several hundred to as high as 1,450 gpm).

- Lithology data, as derived from driller's logs, were provided for 33 wells (10, 13, and 10 wells in the Western, Central, and Eastern Imperial Valley, respectively).

- Water quality data were provided for 279 wells $(115,39$, and 125 wells in the Western, Central, and Eastern Imperial Valley, respectively). Many locations reported results for several sampling dates. In the Western Valley, salinity values (expressed as TDS) ranged between 300 to as high as 13,000 parts per million (ppm). In the Central Valley they generally ranged between 1,000 and 2,000 ppm to as high as $15,700 \mathrm{ppm}$. In the Eastern Valley they generally ranged between $600 \mathrm{ppm}$ and 7,200 ppm. Although high, these water quality levels do not necessarily prevent these waters from being used for Salton Sea restoration purposes.

- Hydraulic conductivities from 16 wells tested in Western, Central, and Eastern Imperial Valley were provided, revealing values ranging from as low as $0.6 \mathrm{ft} / \mathrm{d}$ (in Central Imperial Valley) to as high as $1336 \mathrm{ft} / \mathrm{d}$ (in two wells in the Eastern Imperial Valley).

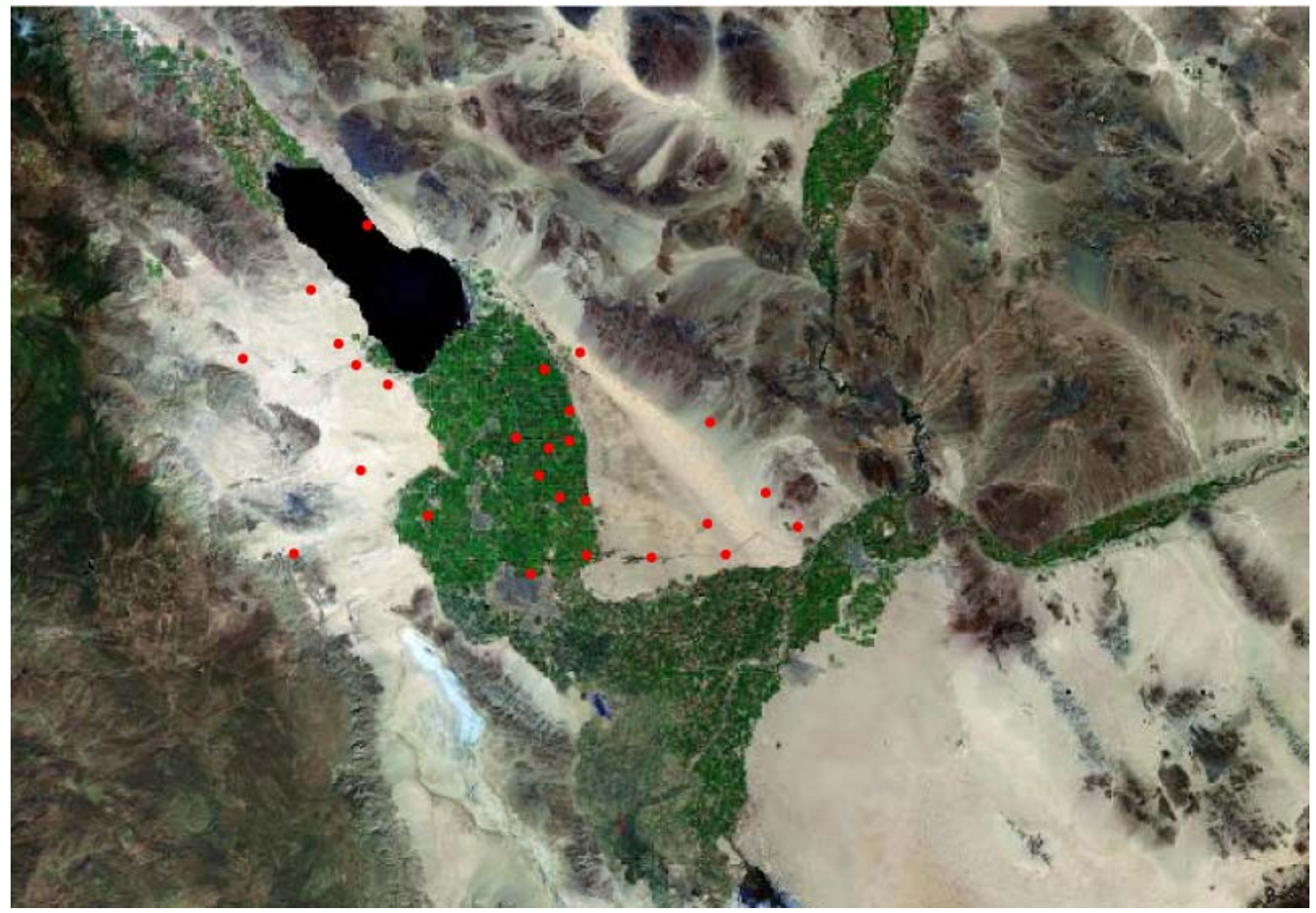

Figure 2.9: Satellite photo of the Salton Sea area showing irrigated agricultural regions in the Coachella Valley (north of Sea) in the Imperial and Mexicali Valleys (south of Sea). The locations of a selection of wells in the Imperial Valley tabulated in the geohydrologic assessment of Loeltz et al. (1975) are also shown. 
This tabulation serves as a model for the database development undertaken in Phase I of this project (see below in Section 3). Other sources of data for groundwater and wells in the basin (e.g., in the West Mesa, Borrego Valley, and Coachella Valley areas) exist in public and private databases maintained by, for example, the US Geological Survey, California Department of Water Resources, US Bureau of Reclamation, Imperial Irrigation District, and the Coachella Valley Water District.

In the next section, we will review details and results of an integrated database and GIS project activity focused on developing framework to (i) combine well and groundwater data derived from a more complete set of sources and, ultimately (ii) support a broader and improved groundwater assessment activity in the basin. 



\section{Section 3:}

\section{Phase I Database and GIS Model Development}

In Phase I, a process to acquire, assemble, organize, and make accessible as much of the existing and relevant hard data and interpretive information as possible related to quantifying groundwater availability in the Salton Sea area was established and implemented. Three products or "tools" were developed that are intrinsically linked, accessible, and easy to maintain, and together house all the data for the project. This collection is portable and permits the current work to be continued easily by others as desired. These tools include

- Two electronic databases,

- A geographic information system (GIS) map dynamically linked to the databases, and

- A secure website that was the data portal for the project team.

These tools provide a framework for tracking data and work progress, and systematically organizing and reviewing information as it was acquired. The databases, GIS maps and website are described in the following sections.

\subsection{Project Database}

In the course of compiling background information and obtaining raw data for the Salton Sea region, two electronic databases were developed:

- The Reference Literature Database was created to electronically store and manage the diverse and widely scattered collection of reports and interpretive documents related to regional and local geology, hydrology, and water quality in the Salton Sea Basin, including many focused on the Colorado River, geothermal energy, canals and irrigation, and ecology.

- The Salton Sea Water Resources Database was designed for storing and managing the groundwater and surface water data and other related quantitative information. The databases were built using Microsoft Access ("Access") software for its widespread availability, low cost, and portability.

Managing the project information in relational databases provided a structured, organized way of maintaining the data, ensuring its integrity, and most importantly, for extracting key information needed for decision-making by the US Bureau of Reclamation. These two databases are described in more detail in the following sections.

\subsubsection{Literature Reference Database and Library}

The Reference Literature Database was created to electronically store and manage the diverse and widely scattered collection of reports and interpretive documents related to regional and local geology, hydrology, and water quality in the Salton Sea Basin, including many focused on the Colorado River, geothermal energy, canals and irrigation, and local ecology. 
If available, electronic versions of desired references were posted electronically to an 'Elibrary' on an internal (non-public) website at LLNL for the project team's use (described further below). The electronic file formats include either the Adobe Acrobat Portable Document Format $^{5}$ ("pdf") or the Mozilla Djvu ("djvu") format. If only available in printed form, desired references were first digitized into an electronic pdf format and then posted to the website. Several steps are involved in the process from identifying likely references to ultimately posting them to the E-library. To streamline the process, a system was developed to acquire, catalog, post to the website, and finally, to facilitate review by the project team.

The E-library was initially populated with hard copy references on loan to project staff from the Bureau of Reclamation. The next step in the process involved compiling a list of additional technical references. The list included professional papers published by the U. S. Geological Survey (USGS) and other government research groups, journal articles, agency publications, geologic bulletins, theses, congressional act transcripts, engineering consultants reports, driller's logs, and hydrologic and geologic maps. Many of these references were available electronically. Other references were purchased or borrowed, then electronically scanned for distribution and website posting.

A data-entry form was created to ensure that all the important information was recorded during the process of entering and cataloging the literature references in the electronic database. In addition to the standard information (e.g., author, reference type, publication date, copyright protections, etc.), a library of key words was produced to facilitate later searching of key documents and/or information. Following document acquisition (and scanning, if necessary), an individual document code (e.g., 'LLNL_CODE' ) was assigned for use in (i) tracking data extracted from the document into database tables within the 'Resources Database;' and (ii) identification and tracking in the website E-library.

There are currently 315 references listed in the 'Reference Database', with a library of over 415 unique key words. A listing of these references is given in Appendix B. After many of the documents had been entered into the database, subject category groups became apparent. Thereafter, upon entry, a subject category was assigned to each reference. All documents have associated subject categories. The current subject categories are:

\section{Colorado River}

\section{Water Supply Issues}

\section{Canal and Irrigation Reports}

\section{Geothermal}

5. Regional Hydrology

6. Regional Geology

7. Water Quality

\section{Groundwater Resource Reports}

\section{Legal Documents}

\footnotetext{
${ }^{5}$ Free reader available at www.adobe.com/products/acrobat/readstep2.html

${ }^{6}$ Free reader available at www.djvuzone.org/download/index.html 


\section{Ecology}

\section{Salton Sea - General Interest}

\section{Modeling}

\section{Mexico}

In the reference database, once a document had been assigned an 'LLNL_CODE' and listed as having an electronic (pdf or djvu) file, the reference data and electronic documents were exported to the E-library on the secure web server (see Section 3.2). The E-library website consists of a perl script that automatically separates the references into their respective subject categories and generates the HTML code for the webpage. Entries that have been posted within the last 30 days were also color-coded to allow the user to scroll through the library and quickly locate newly posted entries. Thus, the project team was able to download and review the documents as soon as they were scanned and posted to the website.

To track the data review process, a procedure for recording and sharing reviews was developed. The procedure consists of recording a review summary for the Reference Database documents table. The review summary identified basic document information, which documents have been reviewed and by whom, key data within the reports, and a rationale for culling irrelevant documents. A brief summary of each document was written, project relevancy noted, and new raw data identified. In addition, for each document, comments regarding the Volume, Producibility, Renewability, and Quality topics identified in Section 1 were added as they relate to groundwater or hydrogeologic information contained in the reference. A relational schema of the Reference Literature Database is shown in Figure 3.1.

\subsubsection{Salton Sea Water Resources Database}

The Salton Sea Water Resources Database is the core relational database developed during the project. It was created to store, organize, and query all acquired water resources data. A spatial relational database enables the information to be mapped via various imaging tools for a clear visual display, significantly increasing their usability and accessibility. Such tools may include

- Geographic Information System (GIS) software, such as the ArcGIS software product line developed by ESRI, or

- Volumetric imaging tools, such as the Earth Vision software product from Dynamic Graphics, Inc.

Information in the database includes well and surface water locations, ground and surface water quality values, depth to water data, surface water flow rates, well construction and lithology details, well yield rates, well type and use statistics, and well ownership information. 


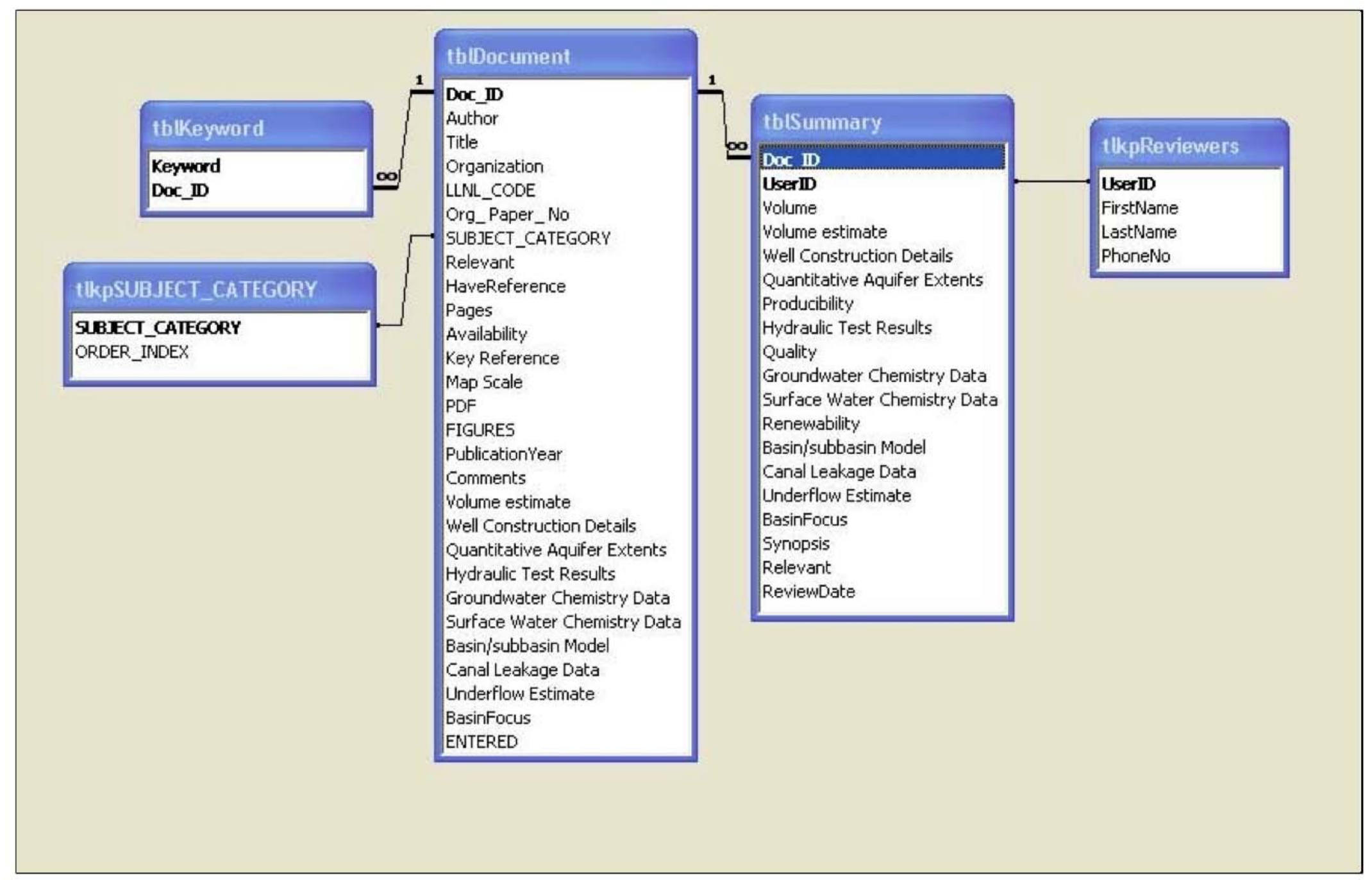

Figure 3.1: Relational schema of the Reference Literature Database. Information in these categories pertains to each of the individual references in the database (the current references are listed in Appendix A). 
Before any data were obtained, a database schema or diagram was designed that showed the categories of data (tables) and their relationships to each other. This is shown partially in Figure 3.2 while a complete list of tables is shown in Appendix C. Designing a schema with referential integrity relationships is essential for ensuring data validity. For example, one of the main tables, tblWells, is regarded as a "parent" table to many related "child" tables such as tblGW_Elev (water levels) and tolChemistry_Data (water quality analytical values). A given well may have multiple data records related to, for example, water level or a particular water quality measurement, as acquired over time (time series) or multiple replicate samples (at one time). Because relationships between the parent and child tables have been established prior to table population, key information such as the well coordinates only needs only to be stored once - in the parent table. All the information from the parent is automatically associated with the child table and visa versa.

Because the data being compiled are derived from many disparate sources, the format, amount of detail, and quality in the data varies greatly. Particular attention has been paid to the process of preparing and managing the incoming data so that it is incorporated into the basic schema in a way that clearly identifies its format, level of detail, data quality, etc. To ensure consistency for current and future developers and users of the database, we have diligently documented our steps for these types of procedures, both in an explanatory guide to the database and in the feature description within the database itself. A good example of this is the spatial location or coordinate information. The coordinates for the parent records are stored in Latitude/Longitude decimal degree format in the tables and projected in NAD 83 State Plane California FIPS VI 0406 feet in the map. Because many data employ a different coordinate format, e.g., degrees, minutes, seconds, the conforming decimal degrees format needs to be added as a column in the table. The original coordinates remain, but the converted values are used to network with the existing records and GIS map.

In addition to assorted preprocessing, there are also steps taken to ensure thorough data tracking and integrity. An archive of all raw data was kept, with each file name designed to permit tracking, e.g., source (agency name), acquisition date, and data type. These descriptors together make up the file name, for example 'USGS_NWIS_08092004_GWE.txt.' This ground water elevation file is from the US Geological Survey, National $\bar{W}$ ater Information System Web Site, and it was downloaded on August 9, 2004. Furthermore, file names are added as a feature record once the data are incorporated into the appropriate database tables. In this way, every record within the table includes a source file name. So, if ever there is a question regarding a record, it can easily be traced back to the raw data file. Note that no data records are altered - all records remain as they were obtained. We do need to flag known or suspect bad data, however, which is typically handled with an adjacent column and an unambiguous note in the description area of the database outlining the reasoning and rules of flagging. All of the procedures described in this section are clearly summarized in text both internal and external to the database.

As described in Appendix $\mathrm{C}$ and Figure 3.3, we have incorporated data from a variety of sources into the Water Resources Database. Currently the database includes information derived from (often multiple offices) in 17 unique agencies or organizations. Altogether, we have incorporated: 


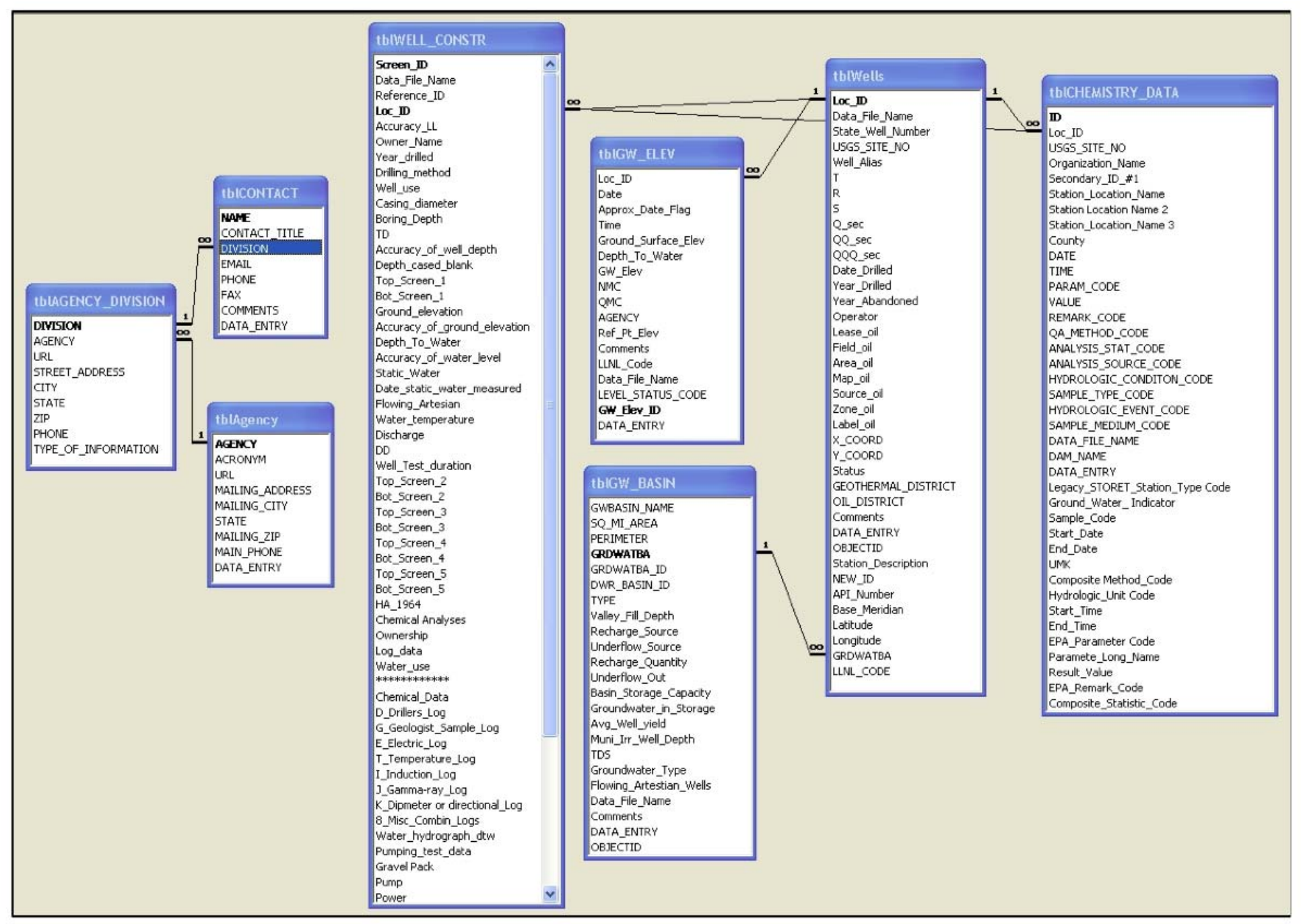

Figure 3.2: Relational schema (partial list) of the Salton Sea Water Resources Database (a complete list of the current database tables is provided in Appendix B) 


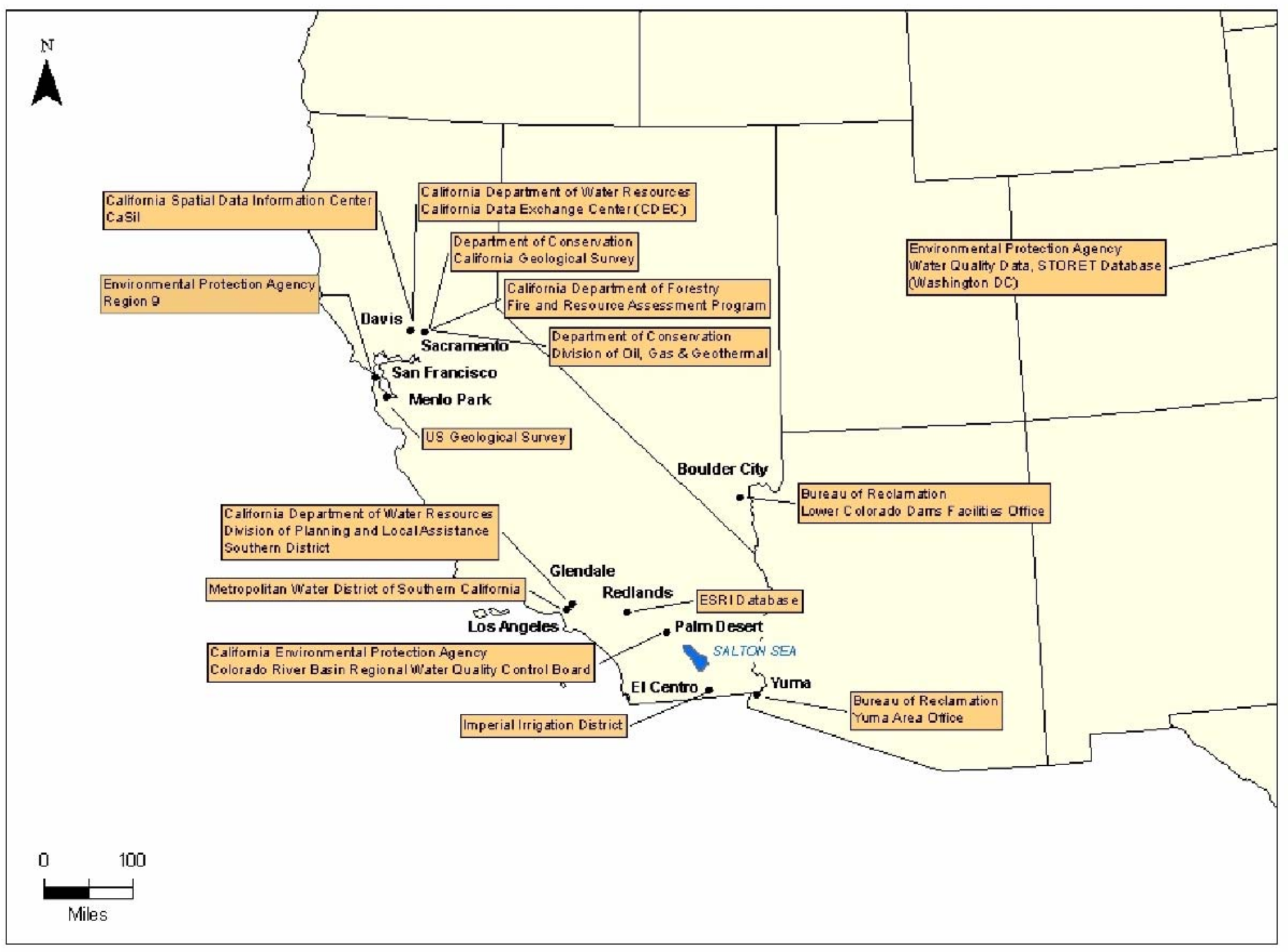

Figure 3.3: A map of the agencies (and their localities) that comprise many of our data sources (see also Appendix C) 
- Data from 46,697 wells and 11,534 surface water-monitoring stations located in Imperial, San Diego, and Riverside Counties (58,231 total; Figures 4.2 and 4.3).

- Of these, 5,937 wells and 1,736 surface water locations lie in the Salton Sea watershed (as is clear in Figures 4.2 and 4.3)

- Very few data representing proprietary data held by various local agencies, such as the Coachella valley Water District, are (currently) included.

- Proprietary Drillers logs were obtained from a large number of wells in Imperial County (Figure 4.1).

In Section 4, several GIS-based example images reflecting information drawn from the Salton Sea Water Resource database are shown for reference.

\subsection{Project Website Development}

Another tool developed in the project is the Salton Sea Intranet Website. The website was designed to serve as an information portal for the project team. It provided direct access to information and reference literature in the databases and to an interactive ArcIMS map. The site was comprised of five principal pages:

- The Background page summarizes the scope and purpose of the project, including preliminary proposals, a statement of work, and a description of the project phases and work elements.

- The Contacts page listed all the contact information (address, phone number, and e-mail) of key personnel associated with the project, ranging from the Lower Colorado River office of the U. S. Bureau of Reclamation to the Lawrence Livermore National Laboratory project team. Contact information for agency data sources is stored elsewhere - within tables in the Resources database.

- The ArcIMS map page provides a means to generate GIS maps to display and analyze data from the Salton Sea Water Resource database. The Salton Sea Basin map is connected to all the database tables via a geodatabase created from the Resources Database.

- The E-library, described above currently contains 315 electronic documents organized by subject (See Appendix B). A table of contents organizes the reference documents into broad subject categories on the web page. The documents are listed by their title, authoring institution, author, year published, and LLNL_code used in their organization. When a visitor clicks on the LLNL_code name, either the Adobe Acrobat (pdf) or LizardTech (djvu) reader is launched permitting reading online or downloading. Note that the E-library is a working directory of documents to be reviewed and those reviewed that are considered relevant. In addition to these posted references, many more documents may be found in the selection of links presented in the Links page (described below).

- The Links page is a web portal to all the data sources used in the project (Federal, State and Regional agency section) and also provides a listing of general sources organized by subject. Web links are organized under the following subject headings: 


\section{General Information}

2. Publications (legal documents)

3. Agriculture

4. Geothermal

5. Agencies (Federal, State, Regional)

6. Groundwater

7. Surface water

8. Canals

9. Dams

Each of these five headings contains links to a comprehensive listing of websites that are a gateway to additional information. Typically a link subject area is organized by listing the home page first followed by more specific information within that site. A descriptive title indicates the type of information.

In the next section, a series of maps, images, and related discussions derived from the current Salton Sea Water Resources databases will be provided to illustrate the results and utility of Phase I. 


\section{Section 4: Phase I Database and GIS Products}

In this section, we present and discuss an example series of maps, images, and related products derived from the current Salton Sea Water Resources and Reference Literature databases to illustrate the results and utility of the Phase I project activities. Many of the figures discussed have already appeared above in the preceding sections.

- Figures 3.1 and 3.2 show the relational schema of the Reference Literature and Salton Sea Water Resources databases. Appendices B, C, and D provide a table of the current E-library, descriptions of the tables in the current water resource database, and the data sources employed for the water resource database.

- Several basic GIS maps of the greater Salton Sea area in Southern California and Baja California are shown in Figures 1.1, 2.1, 2.6 and 2.7 above. These maps indicate, individually or collectively, the regional watershed basin, annual average precipitation, state-designated groundwater basins, topographical details, the Colorado River, lined and unlined portions of the imported water canals, and the principal roads and nearby populated areas.

- A three-dimensional geologic model of the Salton Sea Basin is shown in Figure 2.3. This model was developed with the Earth Vision software product and uses digital elevation model (DEM) data from the US and Mexico (in the database), externally provided models of the basin architecture (in reference database), and tectonic features (in the database). This approach easily facilitates a volumetric analysis of the geologic units shown in Table 4.1, for example, which range vertically from the ground surface (or surface topography) to the bottom of the Imperial formation (or the basin basement).

- If the entirety of these units were assumed to be saturated at an average $10 \%$ porosity, then the volume of water in storage would be approximately 4.5 billion AF (Table 4.1). This is greater than the 1.1 to 3 billion AF range cited by Imperial County (1997), yet does not account for any unsaturated zone near the surface. The calculated volume of water in storage could be greater if higher porosity values are used, as suggested in Figure 14 of Dutcher et al. (1972). In this case, use of an approximate porosity versus depth relationship developed in Section 7 yields a water volume in storage closer to 6.5 billion AF (Table 4.1 and Figure 7.3).

- The map in Figure 4.1 shows the townships and ranges in Imperial County from which Department of Water Resource's Water Well Driller's reports were obtained. As indicated, there were no reports for many of the townships. Of the reports obtained, about $10 \%$ have little useful lithologic or well depth information.

- The map in Figure 4.2 shows the locations of US water wells in the database, located both within and outside the Salton Sea watershed (drainage) basin.

- The map in Figure 4.3 shows all US surface water monitoring locations in the database, located both within and outside the Salton Sea watershed (drainage) basin. 
Table 4.1: Volumetric analysis of the geologic units lying above the basement within the Salton Sea Basin (US only). Porosity values approximate (see text).

\begin{tabular}{|c|c|c|c|c|c|c|c|}
\hline Unit & $\begin{array}{c}\text { Total Bulk Volume } \\
{\left[\mathrm{m}^{3}\right]}\end{array}$ & $\begin{array}{c}\text { Porosity } \\
{[\%]}\end{array}$ & $\begin{array}{c}\text { Pore Volume } \\
\qquad\left[\mathbf{m}^{3}\right]\end{array}$ & $\begin{array}{c}\text { Pore Volume } \\
{[\mathrm{AF}]}\end{array}$ & $\begin{array}{c}\text { Porosity }^{1} \\
{[\%]}\end{array}$ & $\begin{array}{c}\text { Pore Volume } \\
\qquad\left[\mathbf{m}^{3}\right]\end{array}$ & $\begin{array}{c}\text { Pore Volume } \\
{[\text { AF }]}\end{array}$ \\
\hline $\begin{array}{l}\text { Post Brawley Formation } \\
\text { (lacustrine, alluvium and } \\
\text { delta sediments) }\end{array}$ & $6,284,460,000,000$ & 10 & $628,446,000,000$ & $509,489,464$ & 35 & $2,199,561,000,000$ & $1,783,213,123$ \\
\hline Brawley Formation & $3,447,910,000,000$ & 10 & $344,791,000,000$ & $279,526,613$ & 35 & $1,206,768,500,000$ & $978,343,145$ \\
\hline $\begin{array}{l}\text { Borrego and Palm } \\
\text { Springs Formation }\end{array}$ & $36,682,784,800,000$ & 10 & $3,668,278,480,000$ & $2,973,921,762$ & 12 & $4,401,934,176,000$ & $3,568,706,115$ \\
\hline Imperial Formation & $9,537,050,000,000$ & 10 & $953,705,000,000$ & $773,181,226$ & 3 & $286,111,500,000$ & $231,954,368$ \\
\hline TOTAL & $55,952,204,800,000$ & & $5,595,220,480,000$ & $4,536,119,065$ & & $8,094,375,176,000$ & $6,562,216,751$ \\
\hline
\end{tabular}

${ }^{1}$ Consistent with data in Tables 7.3a, b footnote 6, Figure 7.3, Section 7 
- The map in Figure 4.4 shows the depth of selected wells in the Salton Sea basin identified in the current database

- The depth of these same wells is shown again in Figure 4.5 in a three-dimensional image that incorporates the geologic model shown in Figure 2.3. Note that most wells are very shallow $(<2,000 \mathrm{ft}$ ), although some extend to significantly deeper locations, most likely associated with geothermal production or exploration.

- The map in Figure 4.6 shows the pumping yield of selected wells in the current Salton Sea Water Resources Database. Notably, the highest production wells are typically found in the perimeter of the basin and in the East Mesa area where the lower permeability delta deposits are less prevalent.

- The maps in Figures 4.7 and 4.8 show wells, well ownership, and land ownership in the East Mesa area, along with a proposed well sampling area (see Section 5), local roads, and populated areas.

- Figure 4.9 shows a map of the Imperial Valley showing, in a combined fashion, well depth, specific conductance of the well water, and well yield for selected wells in the database. Note that not all of these parameters are available (or have been measured) for all of the wells indicated.

- An additional GIS map of the greater Salton Sea area in Southern California and Baja California Norte showing topography overlaid with contours of the mean annual precipitation (on the US side of the border) is shown in Figure 2.7.

- A satellite photo of the Salton Sea area showing irrigated agricultural regions in the Coachella, Imperial and Mexicali Valleys is shown in Figure 2.8. The locations of a selection of wells in the Imperial Valley tabulated in the geohydrologic assessment of Loeltz et al. (1975), also in the database, are overlaid on the image.

- Figure 4.10 shoes a map of wells in the Mexicali Valley, obtained from Reclamation (1994). 


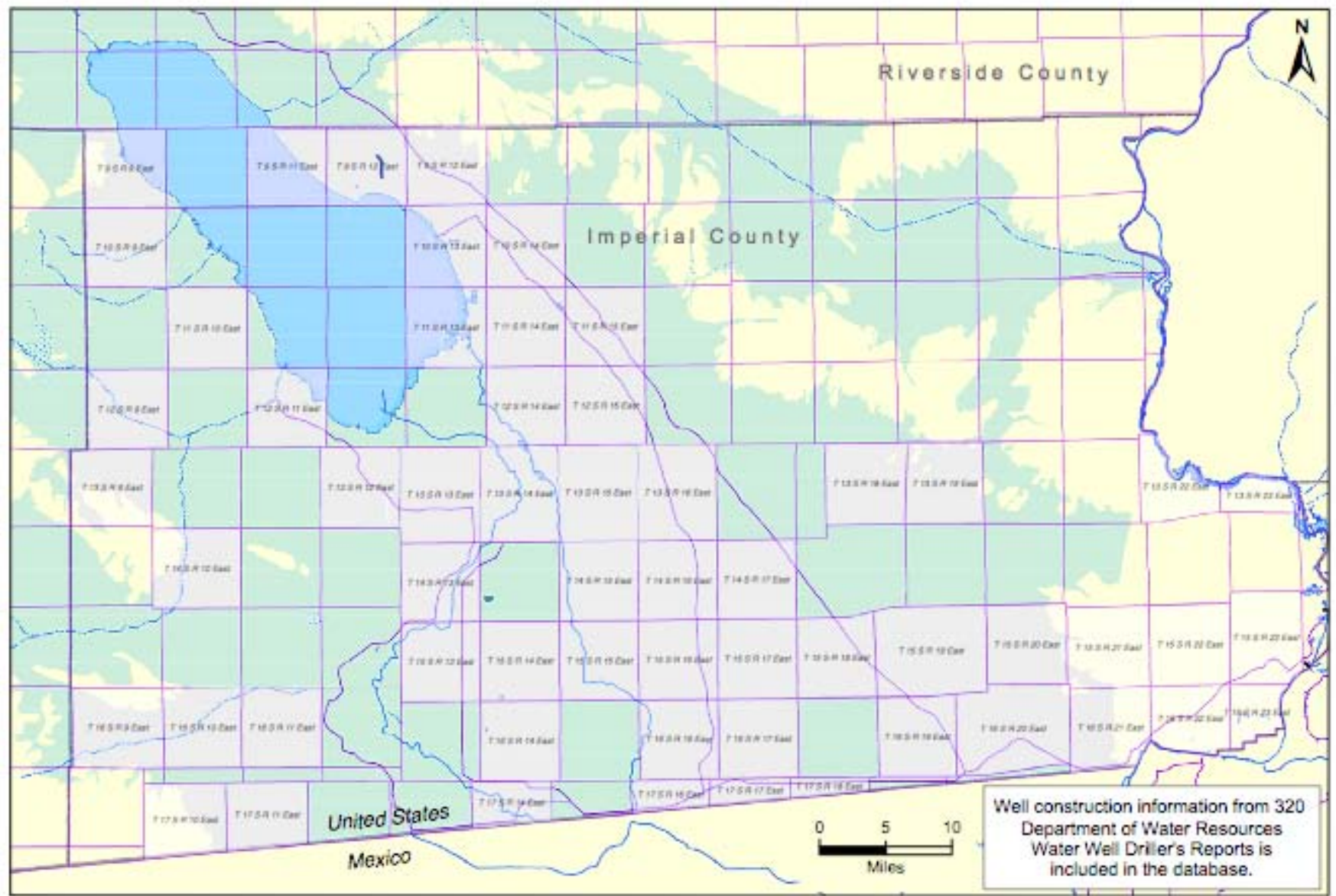

Figure 4.1: Map showing the townships and ranges in Imperial County from which Department of Water Resource's Water Well Driller's reports were obtained. Unlabeled townships have no well reports. 


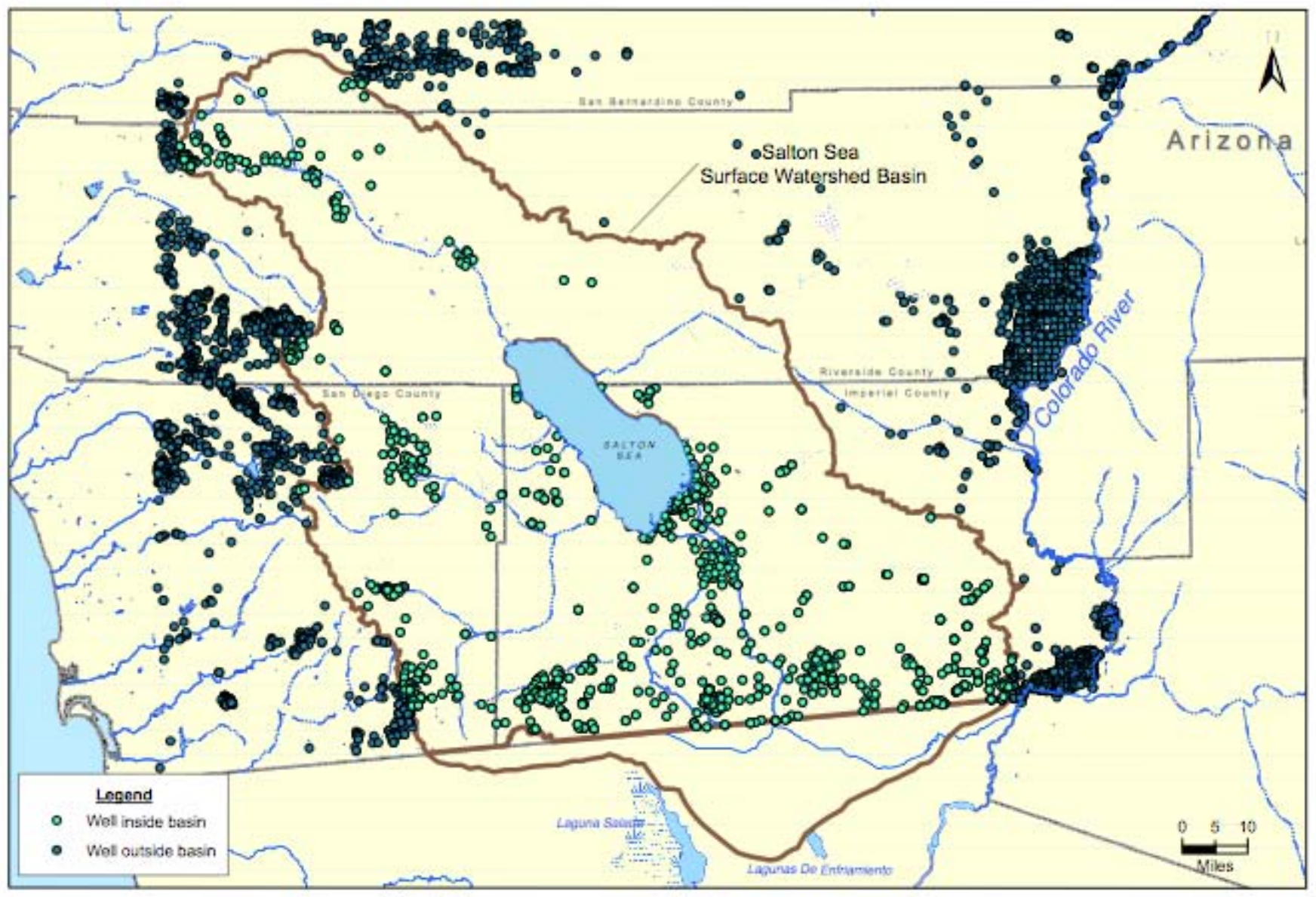

Figure 4.2: Water wells within and outside the surface watershed boundary included in the current Salton Sea Water Resources database (US only). 


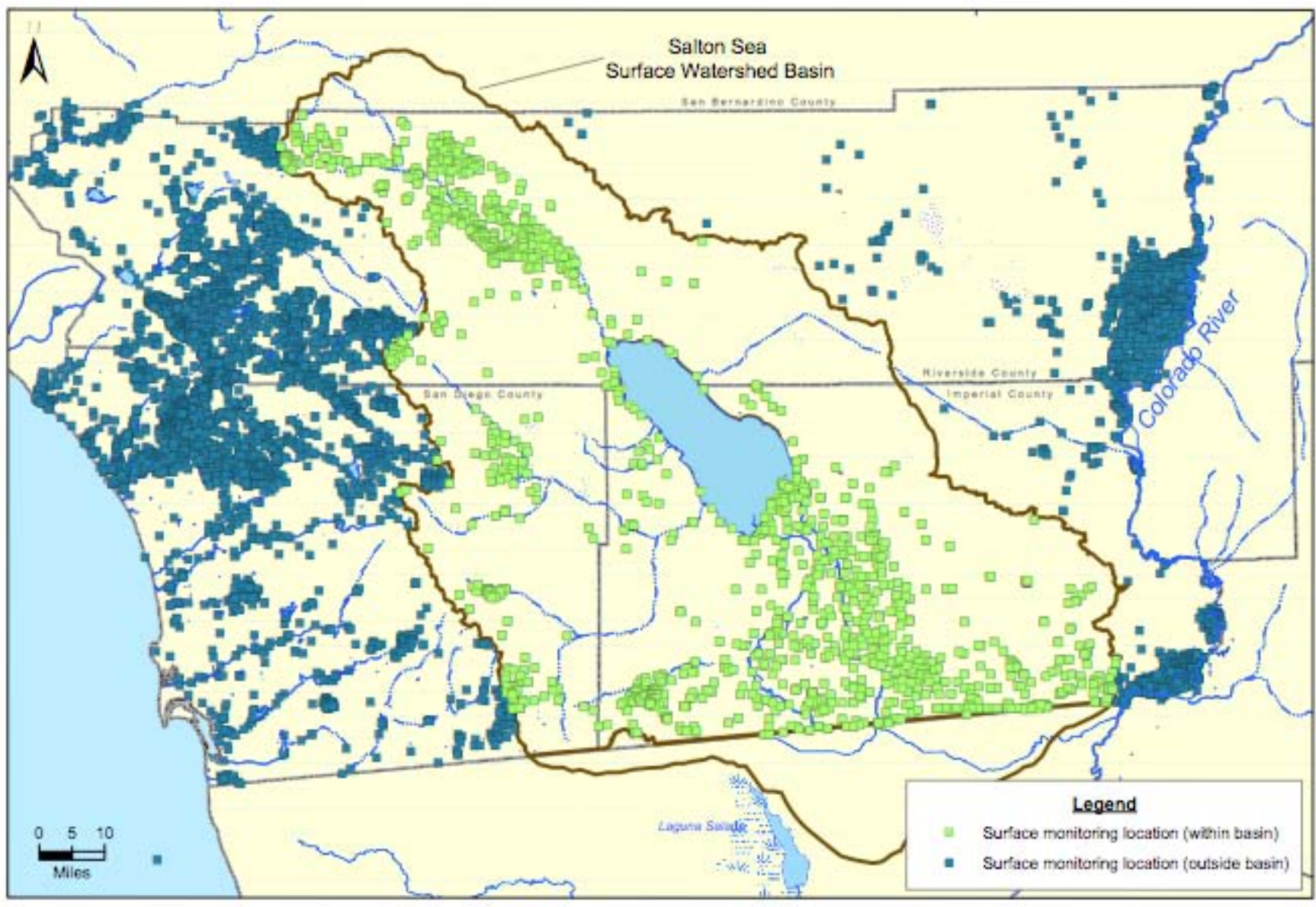

Figure 4.3: Surface water monitoring locations within and outside the surface drainage watershed boundary included in the current Salton Sea Water Resources database (US only). 


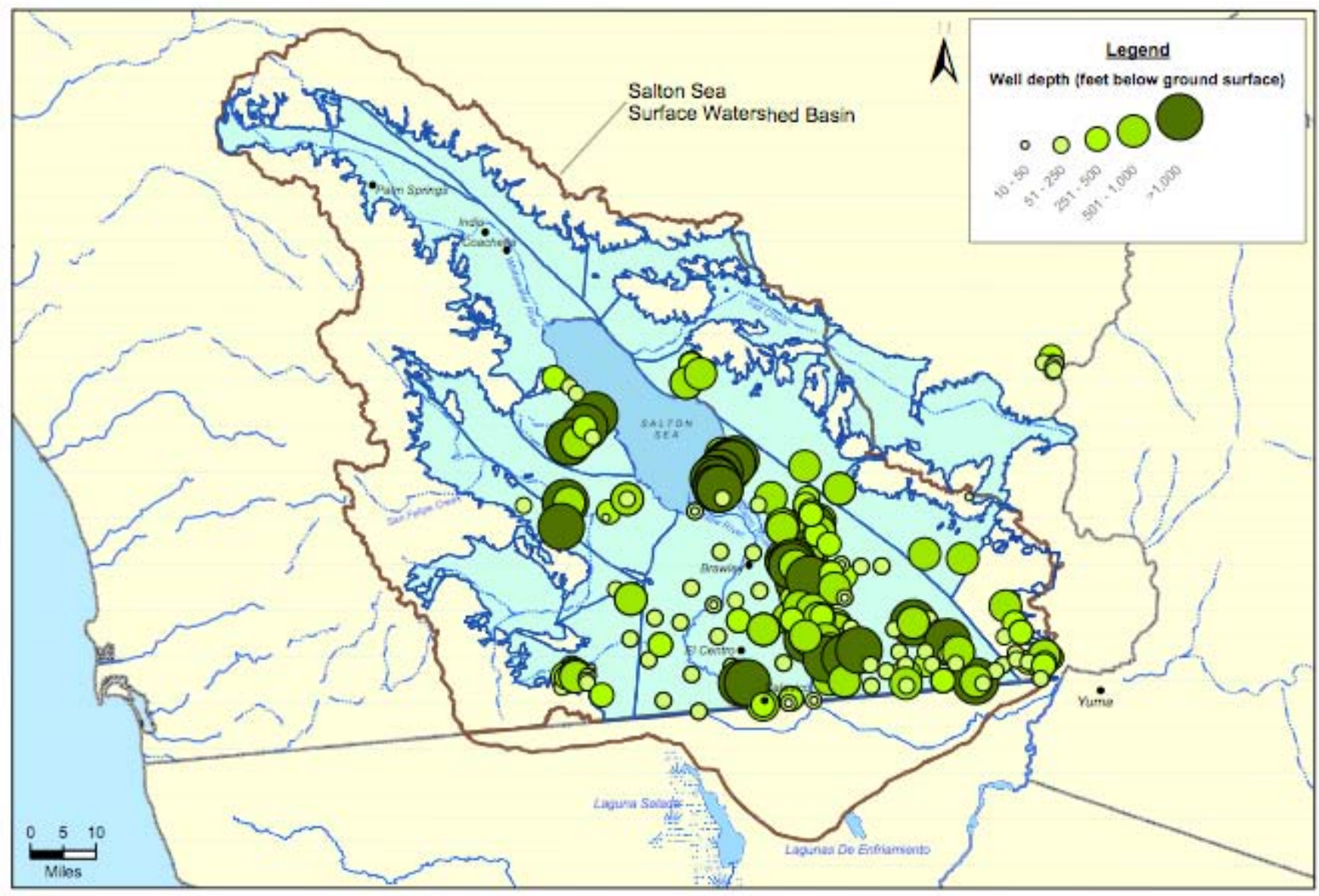

Figure 4.4: Depth of selected wells in the current Salton Sea Water Resources Database 


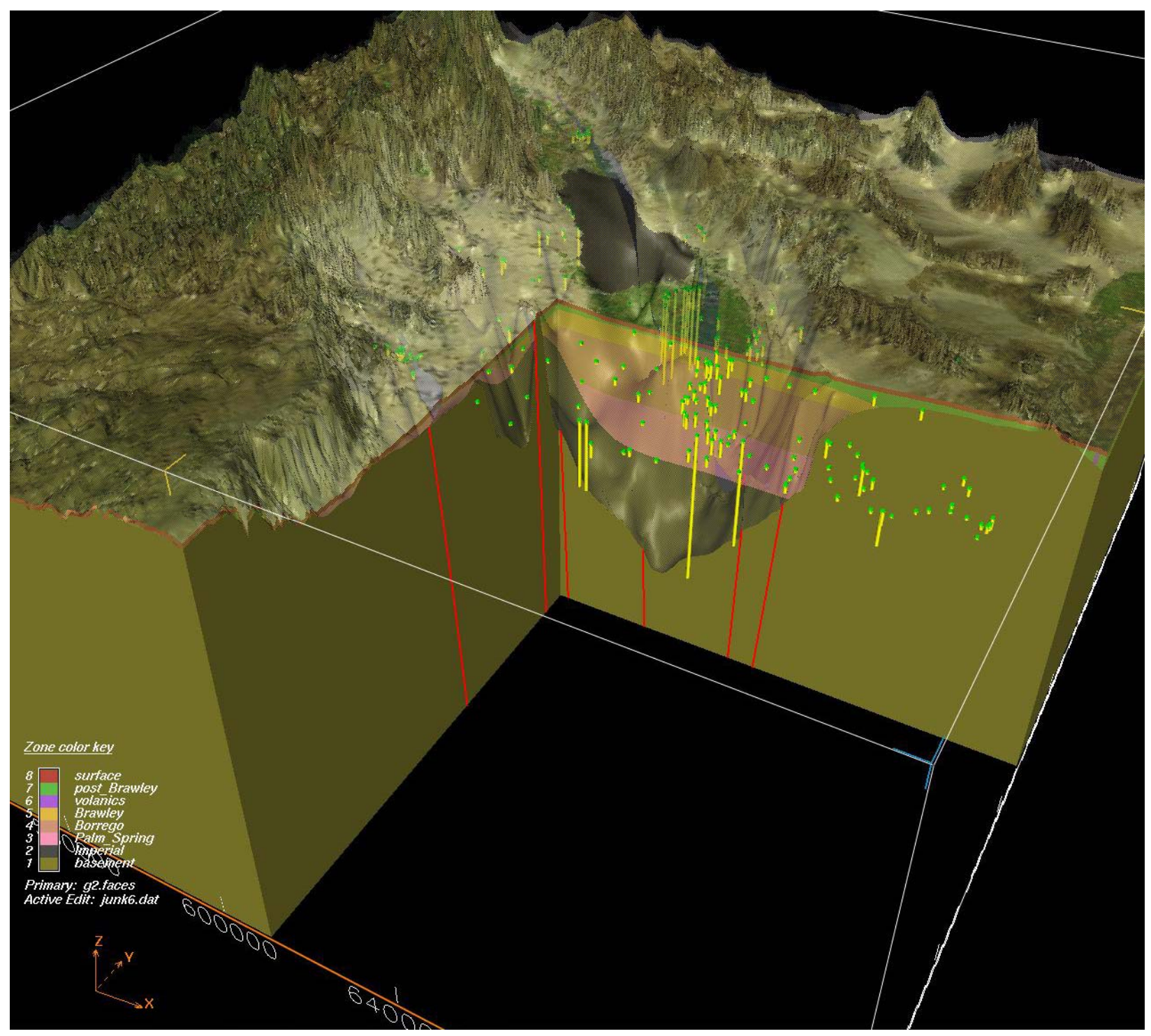

Figure 4.5: Depth of selected wells in the current Salton Sea Water Resources Database overlaid on a three-dimensional geologic model of the basin, looking North, showing the underlying basement materials, the overlying Imperial, Palm Spring, Borrego, and Brawley formations that comprise the "basement complex", and the post-Brawley (delta sediment and alluvial) deposits that extend to the present day surface. The red lines correspond (West to East) to the Elsinore, San Yacinto, Imperial, and San Andreas Fault systems 


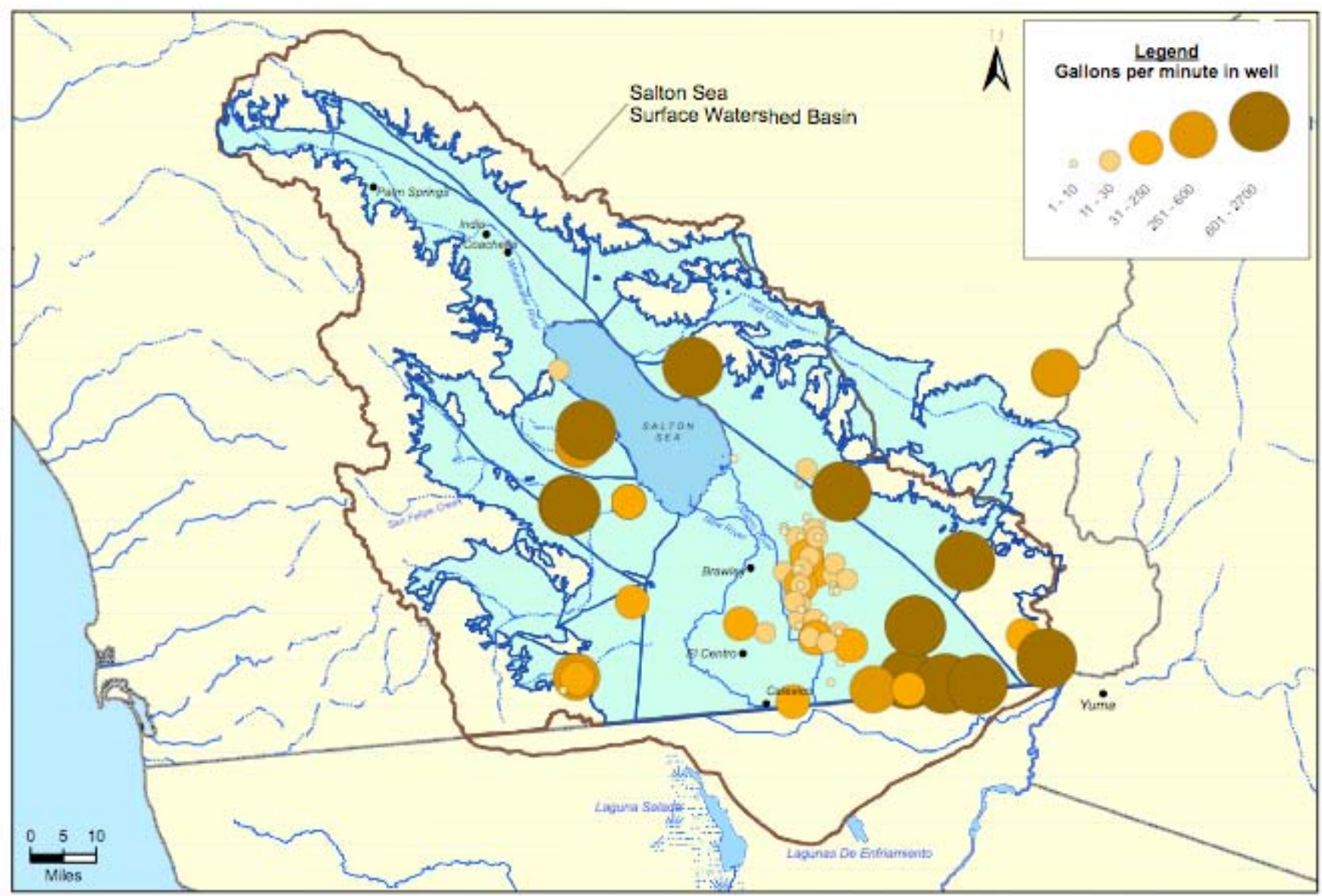

Figure 4.6: Pumping yield of selected wells in the current Salton Sea Water Resources Database 


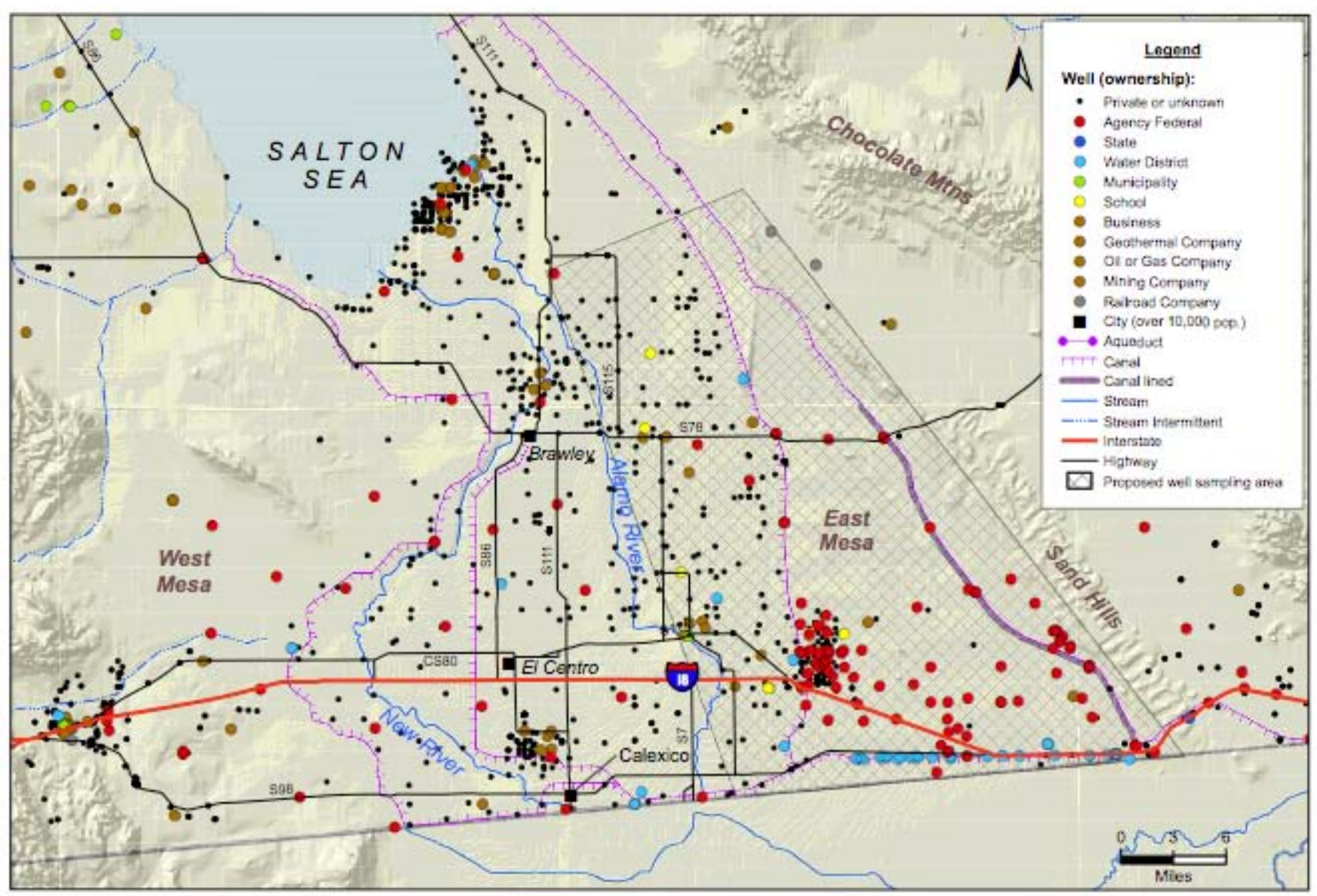

Figure 4.7: Map of the Imperial Valley showing a proposed sampling area and the wells and well ownership in the East Mesa area (see section 5) 


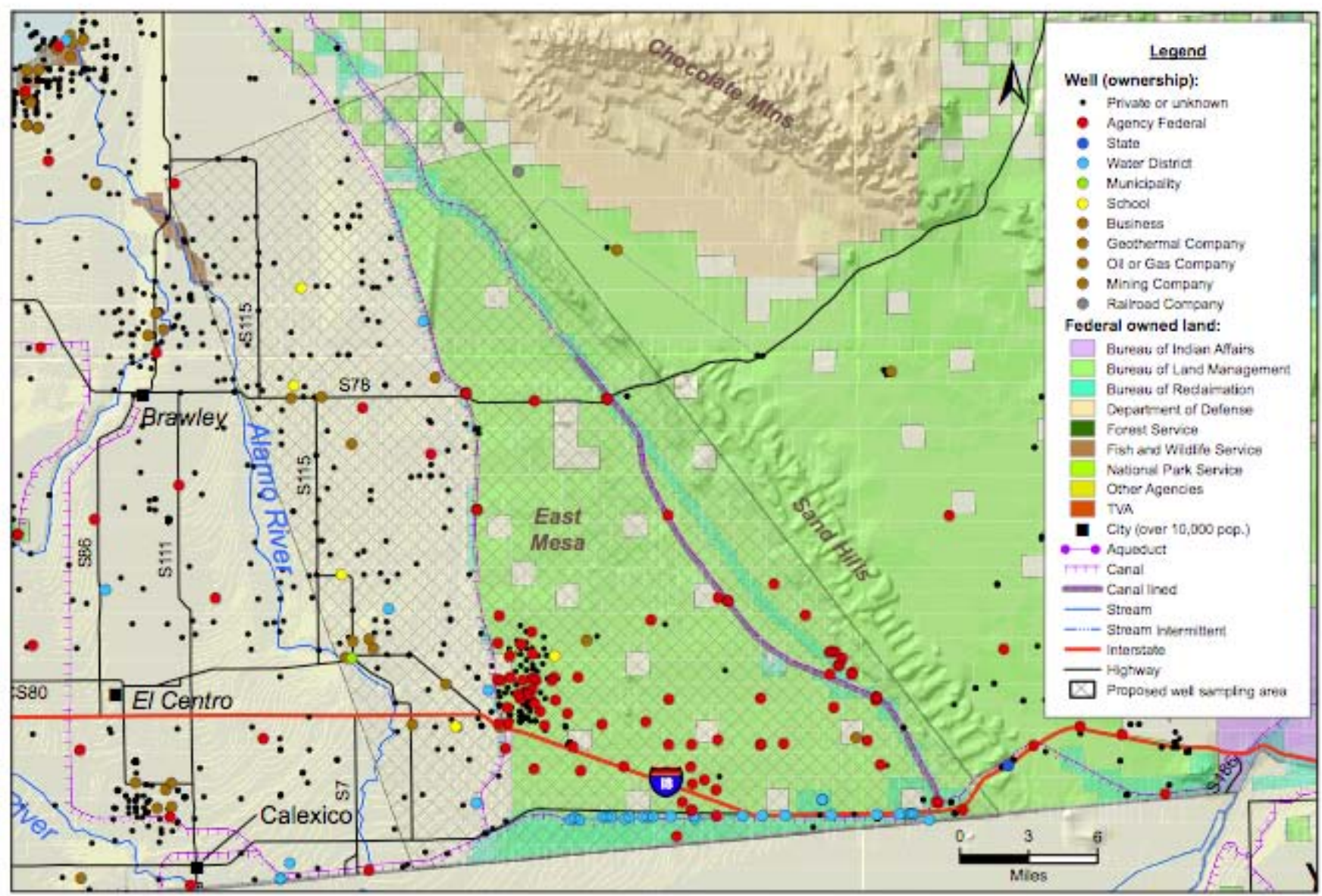

Figure 4.8: Map of the Imperial Valley showing a proposed sampling area and the wells, well ownership, and land ownership in the East Mesa area (see section 5) 


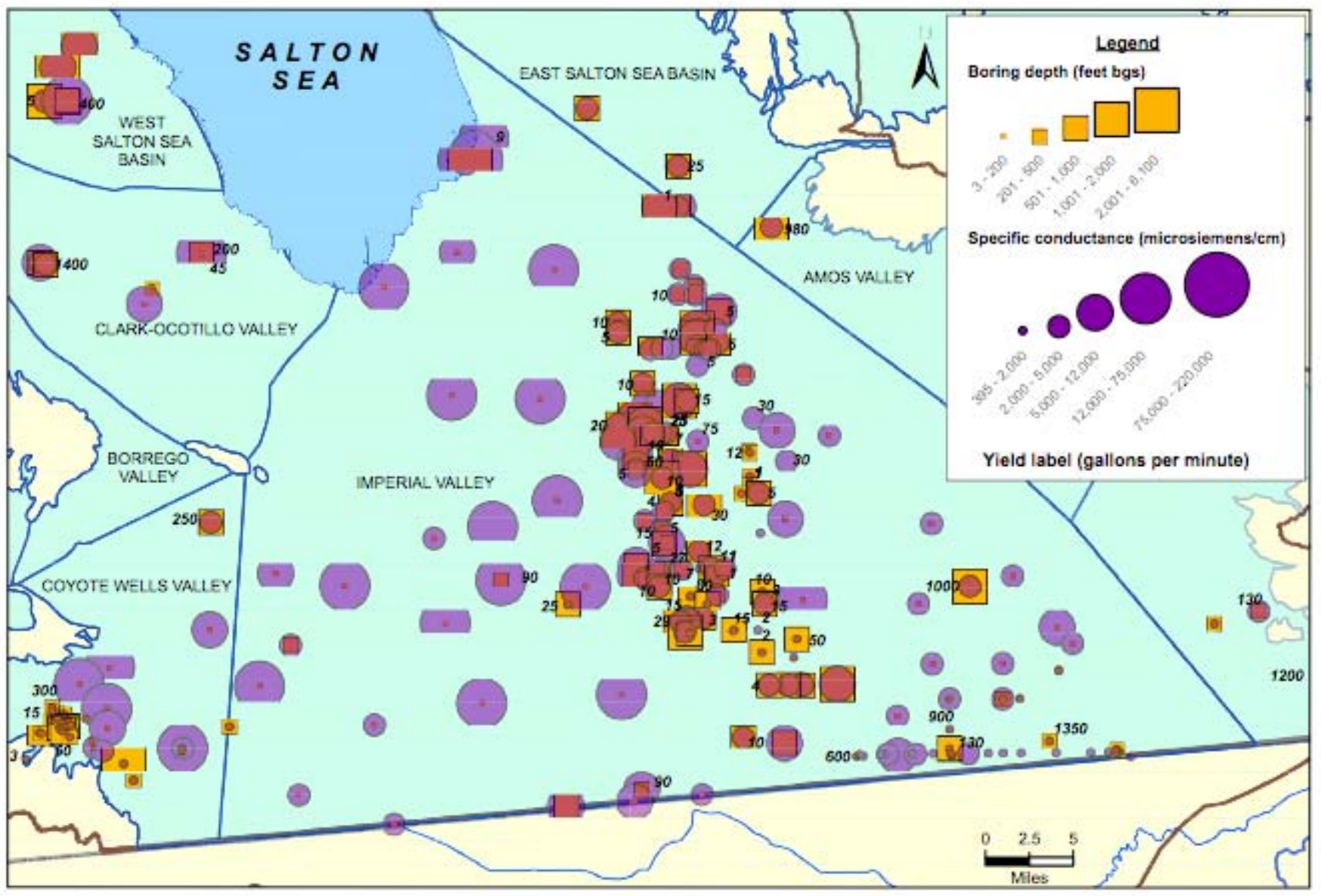

Figure 4.9: Map of the Imperial Valley showing depth of well boring, specific conductance, and yield for selected wells in the adjacent groundwater basins 

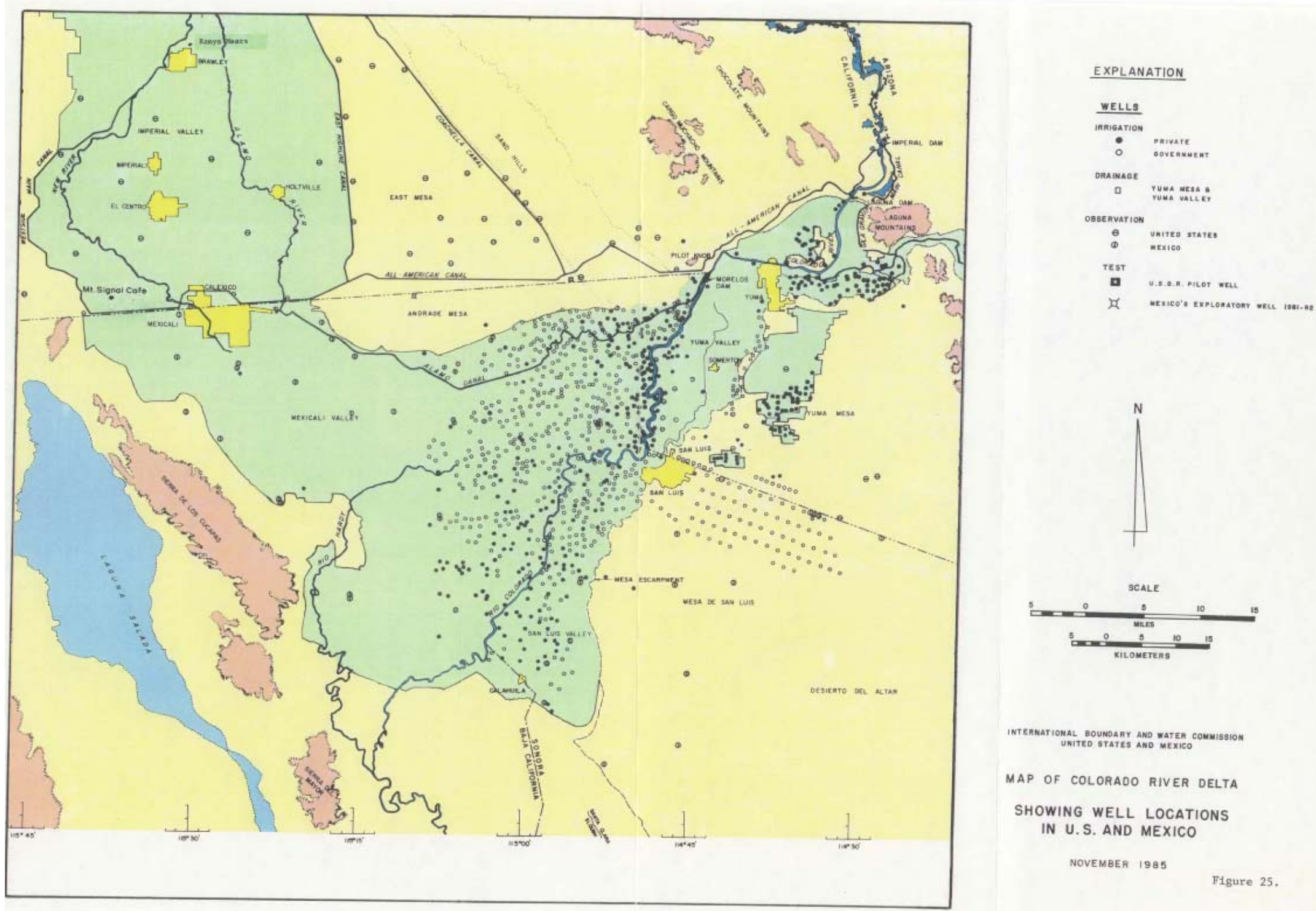

MAP OF COLORADO RIVER DELTA

SHOWING WELL LOCATIONS

IN U.S. AND MEXICO

NOVEMBEF 1985

Figure 4.10: Map of the Imperial and Mexicali Valley border region showing agricultural areas (green) and well locations in the US and Mexico. 



\section{Section 5:}

\section{Concepts for Phase II Activities}

\subsection{Purpose and Scope}

The purpose of this section is to review activities considered for Phase II work in the project. As planned, Phase II work was to include new or additional data acquisition or interpretation activities related to the broad aims of the Groundwater Availability project. Although not all potential options could be pursued under the scope of the project, we considered it a useful exercise to review these options, both as a means to understand their relationship to work that exists or that has been completed, and as a basis to plan future work after this project is completed.

Activities considered for Phase II included, but were not limited to

- Continued acquisition of existing hydrogeologic data for the water resources database

- Refinement and improvement of a basin-wide conceptual model for groundwater flow

- Establishing one or more new field data acquisition efforts

- Development of a new groundwater model

These will be discussed further below.

\subsection{Overview of Potential Phase II Topics}

\subsubsection{Continued Database Development}

This activity would involve the continued acquisition and assimilation of hydrogeologic data for the water resources and literature databases described in Section 3. In part, this would constitute an ongoing maintenance activity in terms of updating transient data, involve the collection of existing data or literature that has not yet been made part of the databases, or entail the inclusion of newly collected data or literature. Specific activities considered but ultimately not done for Phase II include:

- Obtain and import into the database additional well lithology and construction details contained in Department Water Resources (DWR) Well Drillers Reports for other wells in the basin, outside of Imperial County, which had been completed in Phase I. New areas of report collection could include those portions of southern San Bernardino County and eastern San Diego Counties that are located within the Salton Sea basin.

- Develop opportunities to confer with representatives from nearby government or water agencies (e.g., Imperial County, the Imperial Irrigation District, the Coachella Valley Water District, Metropolitan Water District of Southern 
California, and the San Diego County Water Authority) as a means to potentially share data

- Obtain and import California Department of Health Services Drinking water well analyses for wells in the basin. They do regular sampling of a set of wells within each groundwater basin;

- Import all surface water flow, TDS, EC, and temperature hourly data (from the Colorado River dam system gauge stations).

- Obtain additional hydrogeologic data from Mexico pertinent to the development of conceptual and numerical models of groundwater flow in the Imperial valley region;

- Obtain county-wide general plans that contain a 'Water Element/chapter' from San Bernardino Counties to complement that from Imperial and San Diego Counties

- Obtain information regarding type of extant and closed landfills, hazardous waste disposal sites, waste treatment lagoons, former nuclear testing facilities, underground storage tanks, irrigated and fallow agricultural land, radioactive waste disposal sites, waste tailing ponds, geothermal disposal waste areas, material stockpiles (metallic ores, gypsum, selenium, etc.);

- Create groundwater basin hydrographs of groundwater level and significant chemical parameters over time and within the depth-discrete well sets/zones identified;

- Examine water quality areal/depth trends for general water quality parameters, specific age-dating parameters, and regional marker parameters associated with geothermal process and the Colorado River water to help determine zones, in particular natural (boron, fluoride, TDS) and anthropogenic contaminants.

- Compile and add all existing information on subsidence

\subsubsection{Refinement of Basin Conceptual Model}

This activity would focus on a series of hierarchical approaches related to developing improved or updated conceptual models of the basin, as a whole or in part, and the aquifers that comprise it. This activity is a necessary prerequisite for any type of numerical groundwater modeling exercise, and will be dependent on an analysis of pertinent information contained in the database (Section 3). Unless otherwise noted, these activities would not necessarily involve acquisition of new field data (although it would benefit from any new information determined in an "ongoing" sense, see above, or in a specific sense, as discussed below).

For organizational purposes, this hierarchy of conceptual models can be referred to as outlined below:

- Tier 1: Here, the entire Salton Sea basin - including all groundwater basins referred to in Table 2.3 and Figure 2.6 - would be considered as the basis to develop a fully three-dimensional conceptual flow model. This would include the construction of a gross basin-wide structural or hydrostratigraphic model, 
extending to the deepest portions of the basin as known today. In general, a hydrostratigraphic approach will focus on the identification, elaboration, and mapping of zones of unique permeability (high, intermediate, low), saturation and pressure (confined, water table, or perched zones), and water characteristics (chemistry, age, recharge source). Tier 1 efforts will also require a basin-wide water balance assessment, including development of an improved precipitation recharge model (as in Appendix A), an estimate of the total basin-wide water withdrawals via wells (likely insignificant in Imperial Valley), including geothermal activities, estimates of groundwater discharges into the Salton Sea, and a more focused effort at determining historical inputs from canal losses that augment Reclamation reports for Coachella, All-American, and East Highline Canals (e.g., Reclamation, 1989; 1993; 1994). In addition, Tier 1 should make attempts at understanding these issues on the Mexican side of the basin, to the extent that data are available in existing Mexican reports.

- Tier 2: The focus of these activities would involve identifying and characterizing aspects of the basin that serve to either separate or connect its deeper and shallower sections. The idea here is to better understand how, in what ways, and to what extent the shallower sections can be considered independent of the deeper (primarily geothermal) sections in the groundwater assessment, or how, in what ways, and to what extent they must be considered coupled. This effort could include the identification of structural components related to permeability barriers or faults that might otherwise inhibit or allow flow between deep and shallow zones, quantification of drivers of flow, such as the large temperatures that induce deep geothermal recirculation, as well as evidence of such flows as obtained from analysis of water characteristics (chemistry, age, recharge source). These activities should be directed at understanding the magnitude of water fluxes between shallow and deeper areas, and, for example, their overall impacts on water quality in the shallow areas where most wells are located.

- Tier 3: Here, the focus would entail a more detailed characterization of one or more sub-basin areas between the border with Mexico and Coachella Valley Basin (where groundwater resources are fairly well developed), and in particular, on smaller areas with potential for groundwater basin development either by extraction and/or aquifer storage and recovery. These areas will most likely include the mountain front areas along the western perimeter of the basin, south of the Coachella Valley and extending into the West Mesa area and the groundwater mound underlying the All American or Coachella Canals in the East Mesa area. As discussed in Section 2.4, this is suggested by the larger well productivity (and formation permeabilities) in these areas as well as the inherent opportunity to recover water lost (or stored) in the East Mesa following decades of leakage from the All American and Coachella Canals. The level of detail in the conceptual model for these areas (including all aspects discussed in Tiers 1 and 2) should be increased to allow for the development of numerical models for resource development and management (including water volume and water quality). Characterization efforts here will most likely be confined to the shallower 
portions of the basins and should also address lateral groundwater flows across de-facto (non-physical) boundaries used to define these areas.

\subsubsection{Field Data Acquisition Program}

This activity would focus on a series of field investigations to acquire additional data pertinent to, and supportive of the database and conceptual or numerical modeling activities (outlined above and below) and to answer the primary question regarding quantity, quality, and accessibility of groundwater in the basin. Topics for consideration include:

- Well Sampling: Conduct a water sampling program from a series of existing wells in order to elicit information on groundwater age, groundwater recharge source, and groundwater flow pathways, most likely in a localized area of investigation. This kind of information serves to improve our understanding of aquifer behavior, both currently and in the past, and provides useful calibration targets for groundwater simulation models (see Appendix E for detailed information).

- Well Testing: Consider identifying one or more existing wells in the basin for the purposes of conducting one or more hydraulic well tests, possibly in addition to water sampling. Such tests will reveal important aquifer behavior information pertinent to identifying aquifer permeability and flow characteristics, especially as may be used in any aquifer modeling exercise (see below). As noted in Section 3 and elsewhere (e.g., Loeltz et al., 1975) such tests are performed infrequently. A number different test types could be considered, depending of the wells available and the time available for observing aquifer responses.

- Well Drilling: The concept of installing a new production well was proposed prior to the actual initiation of this project as a potential means to illustrate the production of "new" water from an intermediate depth in the basin. Albeit expensive, such a new well, or a smaller multi-level monitoring well or piezometer, would also allow for the acquisition of new hydrostratigraphic information and provide opportunities for new monitoring and water sampling over depth at a not-too-well characterized location.

\subsubsection{Modeling Assessment of Groundwater Availability}

This activity would focus on the development of a new (or updated) numerical computer model of three-dimensional groundwater flow and chemical transport in one or more contiguous groundwater basin areas between the border with Mexico and Coachella Valley Basin (where groundwater resources are fairly well developed), that include, in particular, smaller areas with potential for groundwater basin development either by extraction and/or aquifer storage and recovery. As discussed in Section 2.4, these areas could include the mountain front areas along the western perimeter of the basin, south of the Coachella Valley and extending into the West Mesa area and the groundwater mound underlying the All American or Coachella Canals in the East Mesa area. This activity would be dependent on the parallel development of an appropriate conceptual model (e.g., from Tier 3 above), and would, of course, benefit from the database activities outlined in Section 3. This effort, of course, would also build upon and augment 
previous modeling studies conducted by Skrivan (1977), Mitten et al., (1988), Fogg (1989), Montgomery Watson (1996), or Tetra Tech (1999).

In brief, and in the context of this groundwater assessment, a properly calibrated groundwater model should allow for the identification of exploitable groundwater resources in the chosen study area. It can be used to determine, in an engineering sense, "maximum" and "safe" groundwater extraction rates that can be made under current or future recharge and withdrawal conditions. It can also be used to assess issues related to water quality and water quality changes over the course of pumping. A model necessarily is an integrative tool that makes use of all forms of characteristic data in the system, all on the same "terms". Typical issues that may be addressed by a model include:

- How much groundwater can be physically produced from a target extraction scenario, at what cost, and at what salinity levels?

- Will there be deleterious impacts to other groundwater users, surface facilities, or the environment in the area?

- Will there be limitations on production rate that will accrue over time?

- Can future opportunities for aquifer banking or artificial recharge be examined as a means to promote longer-term conjunctive use of the chosen basin, as is now being conducted in the Coachella Valley Basin (e.g., Montgomery Watson, 2000).

\subsection{Identified Phase II Tasks}

After consideration of time and budgetary constraints, the following two tasks were developed for Phase II of the Groundwater Availability project with input and direction from the U. S. Bureau of Reclamation, Lower Colorado Region Office:

\subsubsection{Groundwater Age and Recharge Source Assessment in the East Mesa}

This effort involves a water sampling program from a series of approximately 40 existing wells in the East Mesa area in order to elicit information on groundwater age, groundwater recharge source, and groundwater flow pathways. This kind of information serves to improve our understanding of aquifer behavior, both currently and in the past, and provides useful calibration targets for groundwater simulation models (Appendix E).

The East Mesa was chosen, in part, because of

- Its larger well productivity (e.g., Figure 4.5)

- A perceived opportunity to assess the fate of water lost (or stored) in the East Mesa following approximately 60 years of leakage from the All American Canal and 40 years of leakage from the Coachella Canal, and

- A perceived opportunity to develop a future aquifer storage and recovery (ASR) project using the All American or Coachella Canals to deliver water for recharge in waterabundant years (e.g., LeRoy Crandall and Associates, 1981, 1983). 
This effort involves both a sampling and investigation component and is described further in Section 6.

\subsubsection{Groundwater Model Development in the Imperial Valley Area}

This activity will focus on the initial development of a new numerical computer model of three-dimensional groundwater flow and chemical transport in the southern half of the Salton Sea Basin and northern portion of the Mexicali Valley in Mexico. When fully calibrated and tested, the model is expected to allow for

- Analyses of groundwater movements, primarily in the shallower aquifer, between the western mountain ranges, the East Mesa, and the Colorado River, all as a function of recharge, discharge, and historical canal leakage processes,

- Investigations of the impacts of canal lining to groundwater movements in the East Mesa Area,

- Quantitative assessment of the viability and impact of new groundwater extraction opportunities in the mountain front areas along the western perimeter of the basin, extending into the West Mesa area, and the groundwater mound underlying the All American or Coachella Canals in the East Mesa area, as identified in Section 2.4 and Appendix A.

- Engineering assessments of the efficacy of new groundwater banking (ASAR) opportunities in the East Mesa area

Any valuable model of this sort will require substantive, iterative, and ongoing development over its lifetime. The work in this project covers an initial phase of this effort and is detailed in Section 7. 



\section{Section 6:}

\section{Phase II Groundwater Sampling and Isotopic Analyses in the East Mesa Area}

\subsection{Overview}

The objective of this activity is to obtain and utilize isotopic tracers of the water molecule to assess the age and source of groundwater in the East Mesa area as a means to understand both historical water migration processes from canal leakage and evaluate future opportunities for aquifer storage and recovery (ASR) in this area.

This effort involved both a sampling and investigation component. As originally envisioned, the sampling plan would ideally involve the selection and sampling of approximately 40 wells in a study area in the East Mesa shown in Figures 4.7 and 4.8, including all relevant laboratory analyses. A basic strategy of the selection process would involve

- Sampling wells along a "line" extending from the All American Canal towards the Salton Sea;

- Sampling wells along one or more "lines" approximately parallel with the Canal; and

- Sampling wells along these lines at a number of depths, including, if possible, wells that extend into deeper parts of the basin

The investigation component of this activity would involve assessing, assimilating, and documenting the results with regard for their revelations about the potential for recovery of water in this area and future opportunities for aquifer storage and recovery (ASR) operations.

The sampling effort was carried out on visits to Imperial County on April 23-26 and June 23-27, 2007. As ultimately realized, 19 sampling locations were visited and water samples were only collected from 13, despite the fact that a larger number of existing wells had been sought for sampling (Figures 6.1 and 6.2). On the ground, sampling efforts were primarily impeded by the inability to find wells or inaccessibility issues, as with locks or gates that prevented access to wells. In a more general sense, sampling efforts were restricted by an overall lack of wells consistent with the sampling strategy outlined above.

In the next section, the use of isotopic tracers of the water molecule to characterize groundwater source and age is reviewed, especially as it pertains to "groundwater availability" in the Salton Sea basin. Stable isotopes of water in preserved groundwater samples can be used to establish the provenance of the sample, while radioactive isotopes (e.g., tritium) can be used to determine the residence time of the sample in the saturated (groundwater) state. Both stable and radioactive isotopes of water can help delineate recharge areas and groundwater flow pathways. Moreover, these techniques can be augmented through comparisons with co-contaminants, major cations or anions, trace elements, or other characteristics identified in the same tested water samples (e.g., Moran and Halliwell, 2003; Moran et al. 2002a,b; 2003; 2005a,b; Tompson et al., 1999; 2006). 
Following this introduction, the sampling effort will be reviewed. This will include a short summary of the wells identified and sampled as well as a summary and interpretation of the analyses made on the water samples.

\subsection{Isotopic Tracers in Groundwater}

\subsubsection{Tritium-Helium Age Dating Techniques}

Tritium $\left({ }^{3} \mathrm{H}\right)$ is a very low abundance (around 1 part in $10^{17}$ of total hydrogen), radioactive isotope of hydrogen with a half-life of 12.34 years. Natural tritium is produced in the earth's atmosphere by cosmic radiation. Atmospheric nuclear weapons testing in the 1950's and early 1960's released tritium to the atmosphere at levels several orders of magnitude above the background concentration (Figure 6.1). This atmospheric tritium enters groundwater (as HTO, with one hydrogen atom as tritium) during recharge. Tritium concentration in groundwater is reported in units of picoCuries per liter $(\mathrm{pCi} / \mathrm{L})$, and has a regulatory limit (Maximum Contaminant Level or MCL) of 20,000 pCi/L.

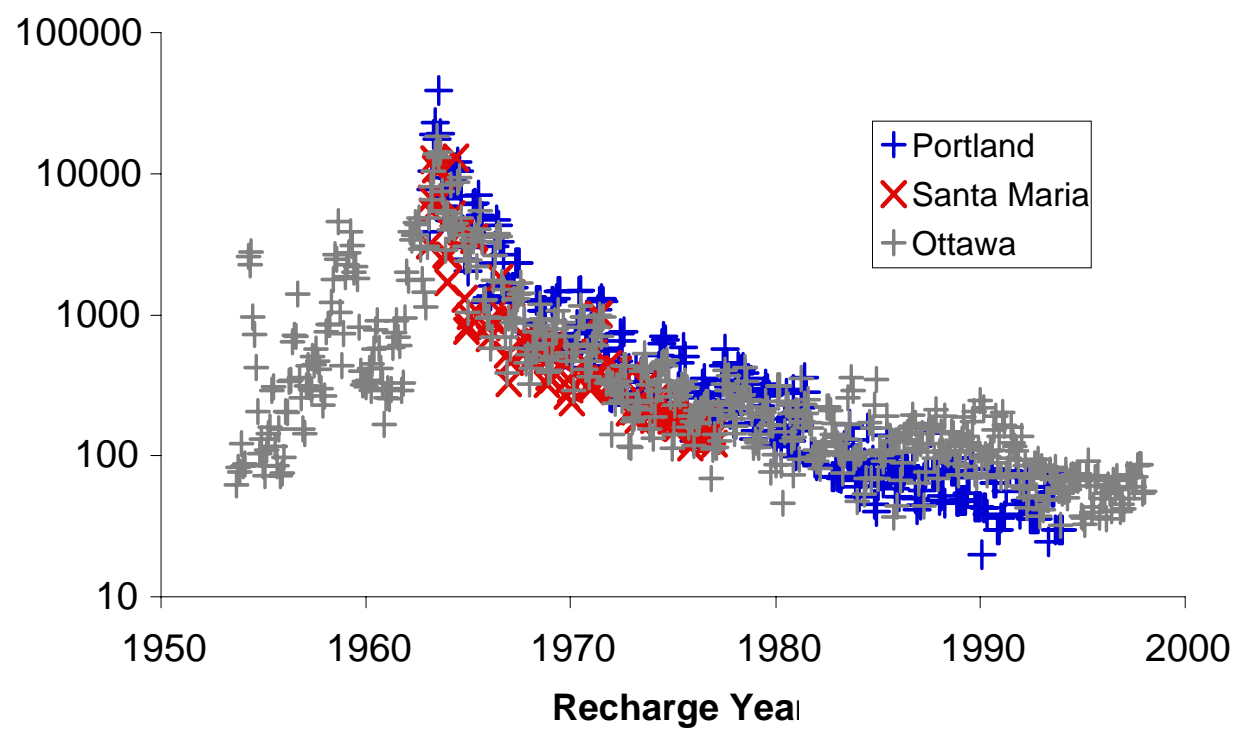

Figure 6.1. The tritium concentration measured in precipitation at three North American locations. Nuclear weapons testing introduced a large amount of tritium into the atmosphere in the 1960's, peaking in 1963

The tritium concentration in a parcel of groundwater will decrease over time by radioactive decay. It can be further modified if the parcel is "mixed" with another (e.g., one that is very old, with no tritium) as may occur by diffusion and dispersion processes in the subsurface regime, or through mixing when sampling a well with a large open interval (which may effectively pull in many different parcels of water over its depth).

While the presence of tritium is an excellent indicator of groundwater that has recharged less than (about) 50 years ago, age dating groundwater using tritium alone results in large uncertainties due to spatial and temporal variation in the initial tritium at recharge. Measurement of both tritium and its daughter product helium-3 $\left({ }^{3} \mathrm{He}\right)$ allows calculation of the initial tritium 
present at the time of recharge (Figure 6.2), and ages can be determined from the following relationship:

(6.1) Groundwater Age (years $)=-17.8 \times \ln \left(1+{ }^{3} \mathrm{He}_{\text {tritium }}{ }^{\beta} \mathrm{H}\right)$

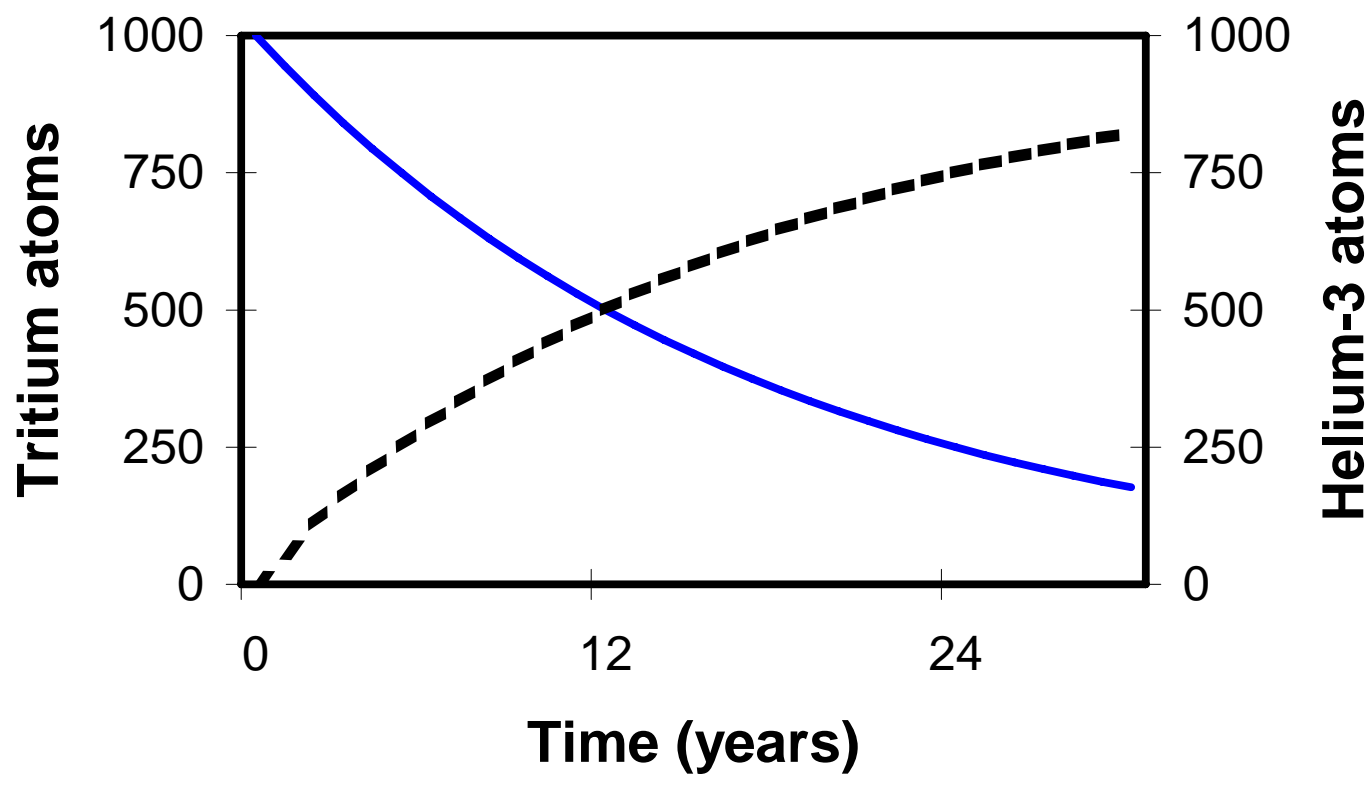

Figure 6.2. Solid line shows the decay of tritium, with a half-life of 12.34 years, while the dashed line shows the growth of the daughter product, ${ }^{3} \mathrm{He}$. The sum of tritium and ${ }^{3} \mathrm{He}$ is the same at any time, and equal to the initial tritium value. This is the basis for the groundwater age-dating technique proposed in this study.

The age measures the time since the water sample was last in contact with the atmosphere. The ${ }^{3} \mathrm{He}_{\text {trit }}$ indicated in the equation is the component of ${ }^{3} \mathrm{He}$ that is due to the decay of tritium. Methodologies have been developed for correcting for other sources of ${ }^{3} \mathrm{He}$, such as the earth's atmosphere and potential small contributions from thorium and uranium decay (Aesbach-Hertig et al., 1999; Ekwurzel et al., 1994).

Well water samples are always a mixture of water molecules with an age distribution that may span a wide range. The reported groundwater age is the mean age of the mixed sample, and furthermore, is the age only of the portion of the water that contains measurable tritium. Groundwater age dating has been applied in several studies of basin-wide flow and transport (Poreda et al., 1988, Schlosser et al., 1988, Solomon et al., 1992, Ekwurzel et al., 1994, Szabo et al., 1996).

\subsubsection{Stable Isotopes as Tracers of Recharge Source and Evaporation}

The minor stable isotopes of water molecules ${ }^{2} \mathrm{H}$ (deuterium, denoted as D) and ${ }^{18} \mathrm{O}$ vary in precipitation as a function of temperature, elevation and latitude (Craig, 1961; Ingraham \& Taylor, 1991). In the Western U.S., extreme changes in elevation occur over 
relatively short distances. The net effect of isotopic fractionation during evaporation and condensation is that surface water from mountain watersheds has a significantly lower abundance of ${ }^{18} \mathrm{O}$ and $\mathrm{D}$ than coastal water (Figure 6.3). The abundance of these isotopes in groundwater provides a fingerprint of the origin of the source water.

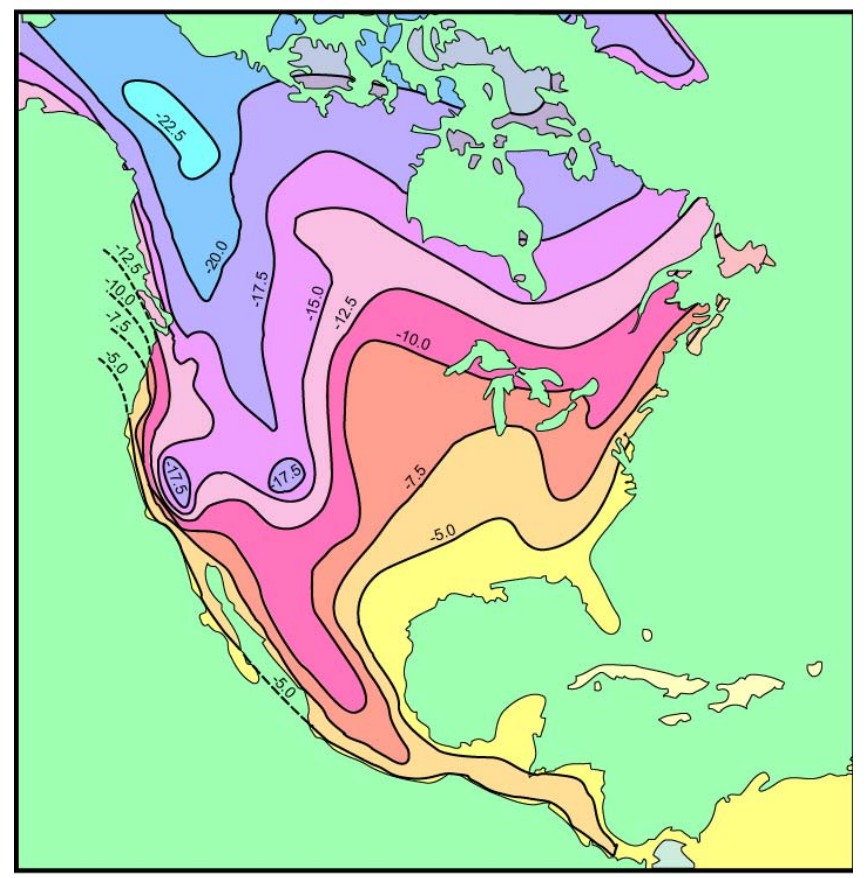

Figure 6.3. Contour map of $\delta^{18} \mathrm{O}$ (SMOW) showing tight contours and lighter, depleted values at high elevation in California (after Taylor, 1974)

Oxygen isotope ratios are reported in the standard delta $(\delta)$ notation as parts per thousand (per mil or \%o) variations relative to a reference material of known composition and defined by

$$
\delta_{x}=1000 \times \frac{R_{x}-R_{s t d}}{R_{s t d}},
$$

where $R_{X}$ is the ${ }^{18} \mathrm{O} /{ }^{16} \mathrm{O}$ ratio of the sample and $R_{\text {std }}$ is the ${ }^{18} \mathrm{O} /{ }^{16} \mathrm{O}$ ratio of the standard. The conventional standard reference material for oxygen isotopes is Standard Mean Ocean Water (SMOW; Craig, 1961). Using the delta notation, $\delta^{18} \mathrm{O}$ in precipitation varies from approximately $-4 \%$ o along the Pacific coast to $-17 \%$ in the Sierra Nevada Mountains and in the Colorado River Basin. Imported water used to supplement water supplies in areas of high water demand nearly always comes from colder and/or higher elevation sources, and has a distinctly lighter $\delta^{18} \mathrm{O}$ signature than local water from within the water-poor watershed. Oxygen isotopes in groundwater can thus provide a fingerprint that identifies the source water location.

Deuterium/protium $\left({ }^{2} \mathrm{H} /{ }^{1} \mathrm{H}\right)$ ratios are fractionated in a similar manner by physical processes of evaporation and condensation, with a corresponding equation for expressing $\delta \mathrm{D}$. Precipitation samples from all over the world thus fall on a line (called the 'Global Meteoric 
Water Line; GMWL) on a plot of $\delta^{18} \mathrm{O}$ vs. $\delta \mathrm{D}$, which has the equation $\delta \mathrm{D}=8 \delta^{18} \mathrm{O}+10$ (Craig, 1961). As illustrated in Figure 6.4, evaporation from surface water bodies shifts both $\delta^{18} \mathrm{O}$ and $\delta \mathrm{D}$ to heavier values below the line, but the larger relative mass difference in the hydrogen isotopes compared to stable oxygen isotopes results in a greater relative shift in the $\delta \mathrm{D}$ isotope ratio, and a line with a slope of 4 to 6 .

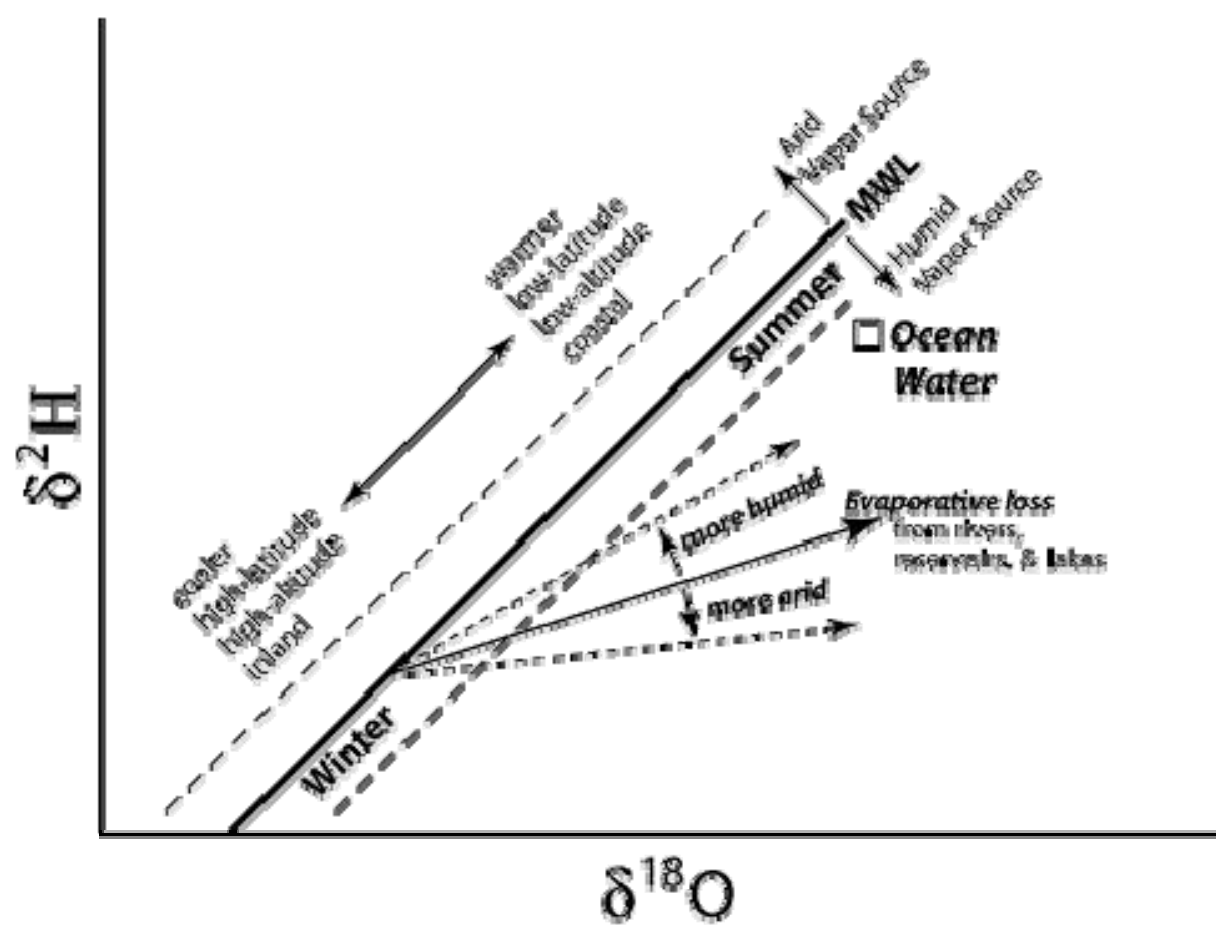

Figure 6.4. Precipitation samples fall along a line (called the Global Meteoric Water Line and labeled GMWL; Craig, 1961) in $\delta^{18} \mathrm{O}$ vs. $\delta D\left(\right.$ or $\left.\delta^{2} \mathrm{H}\right)$ space. Evaporation causes a shift to a line of lower slope.

The most important source of water in the Salton Sea Basin is Colorado River water. River water sampled from a location near the Utah/Colorado state line had measured $\delta^{18} \mathrm{O}$ in the range $-15.4 \%$ o to $-16.6 \%$ from 1984 through 1987 , while $\delta$ D ranged from $-115.4 \%$ o to $-125.2 \%$ o over the same time period (Kendall and Coplen, 2000). The high fraction of light isotopes in these samples indicates that precipitation in the headwaters region is the dominant source of flow in the river. Measured stable isotope pairs consistently fall on the global meteoric water line, indicating that river water itself is not significantly evaporated above Lake Powell. Further downstream, samples from the Colorado River fall on an evaporation trend that extrapolates to the upstream stable isotope values for the river (Figure 6.5). The large surface area of Lake Powell, Lake Mead, and the canals and diversions associated with Imperial Dam, and residence times of several years for water in the reservoir system, results in significant evaporation of water in the Colorado. Stable isotopes in surface water from canals and agricultural drains in the Salton Sea area fall further out along the same evaporation trend, while groundwater samples 
from Imperial County in general are even more evaporated, but still plot along the same line, indicating that they originate as Colorado River water (Figure 6.6). Leakage from unlined canals and infiltration of "excess" irrigation water are the most likely routes of recharge in Imperial County.

Other potential water sources such as local precipitation or drainage from surrounding high elevation areas have stable isotope signatures distinct from the Colorado River signature, all of which fall above the evaporation trend of Colorado River water (Figure 6.5). Since the available groundwater stable isotope analyses (albeit few in number and from a limited geographic area) all plot along the evaporation trend of Colorado River water, these other waters are not likely significant sources of groundwater recharge, at least in the areas sampled to date. This situation is in contrast to what is 'normally' observed around the state of California, where river water may make up a significant fraction of recharge, but where other imported water sources, local precipitation, or older, ambient groundwater contribute significantly to the isotope signature observed in groundwater (Moran et al., 2005; and Figure 6.6 for an example from San Diego and Riverside counties). Clearly, the aridity of the Salton Sea area, and the long history of irrigation with Colorado River water, has marked the groundwater with the evaporated Colorado River stable isotope signature. The depth and spatial extent of this 'marked' groundwater is largely unknown, since there are very few stable isotope analyses of groundwater samples in the Salton Sea area.

In a study of timescales associated with irrigation, storage, and drainage in the Imperial Valley, Michel and Schroeder (1994) found that stable isotopes in samples of shallow groundwater all fell along the evaporated Colorado River trend. Three locations along the valley axis at varying distances from the Salton Sea show differing degrees of evaporation, with the groundwater closest to the sea being most evaporated (Figure 6.7). The most highly evaporated water occurs in the profile nearest the sea at a depth of $50 \mathrm{ft}$ below ground surface. In the southern location, only slightly evaporated water is observed in the shallowest samples, perhaps because that area experiences more rapid infiltration before significant evaporation takes place.

The radioactive isotope of hydrogen, tritium, also has a unique and interesting history of input in the Salton Sea region. As illustrated in Figure 6.1, precipitation had very high tritium concentrations in the early 1960's as a result of atmospheric weapons testing. Physiographic and meteorological conditions in the Colorado River Basin are such that tritium concentrations in source waters from there are higher than for waters from the Imperial Valley. In addition, Glen Canyon dam was completed in 1963 and Lake Powell behind it was filled with highly tritiated water over the following 20 years. The large volume of storage on the Colorado River results in residence times of several years for the surface water in the river/reservoir system (Michel and Schroeder, 1994), so tritium concentrations remained higher than background, precipitation concentrations for at least a decade. Surface water samples from the Colorado River, canals, and agricultural drains had elevated tritium concentrations of about $100 \mathrm{pCi} / \mathrm{L}$ (compared to $75 \mathrm{pCi} / \mathrm{L}$ expected for precipitation) when they were analyzed in 1989 because of the 'memory' of higher tritium created by the storage and residence times of the reservoirs. The combined effect of decreasing tritium in precipitation and decay of tritium in reservoirs suggests that tritium concentrations in surface waters of the Colorado system, including the Salton Sea should be approximately $38 \mathrm{pCi} / \mathrm{L}$ in 2005. 


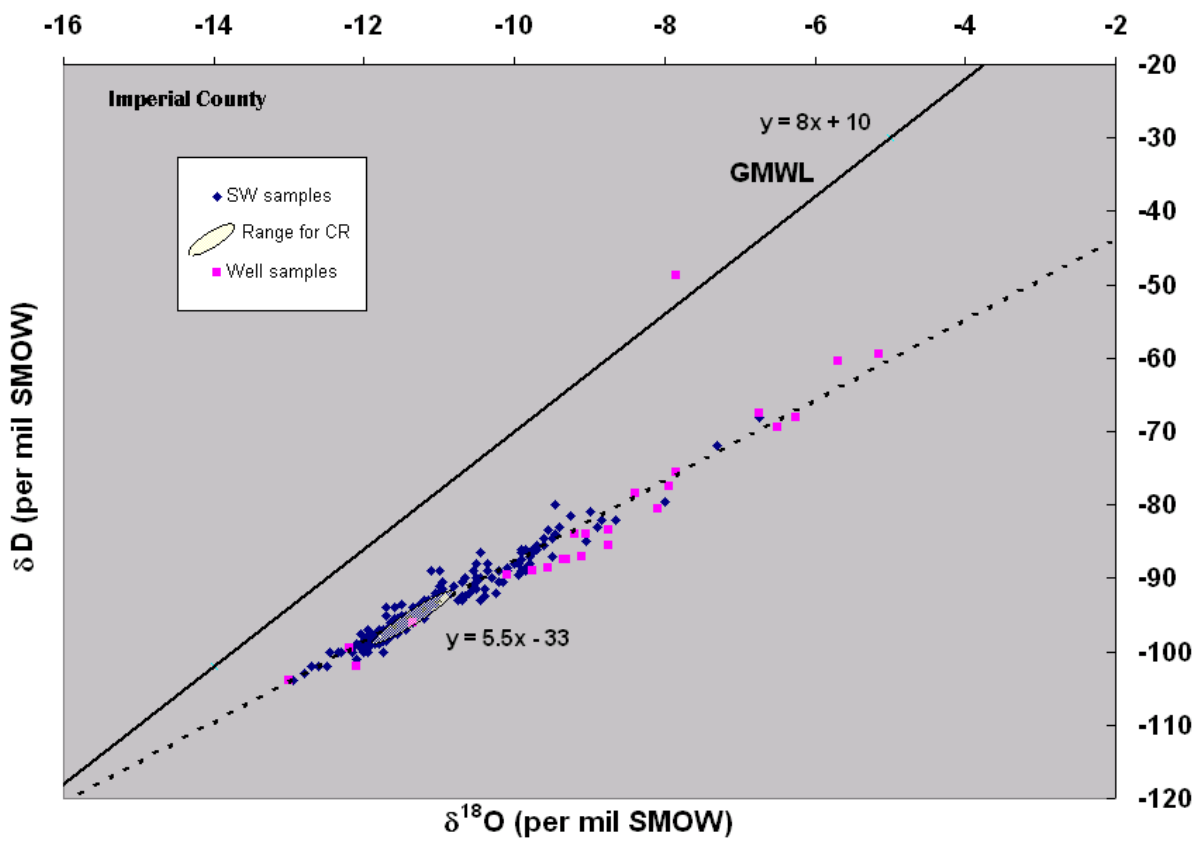

Figure 6.5. Surface water (denoted $\mathrm{SW}$ in the legend) and well water samples from Imperial County all fall along an evaporation trend that extrapolates back to unevaporated Colorado River water, indicative of their common source. The range of observations for Colorado River samples from below the major dams is represented as the shaded oval.

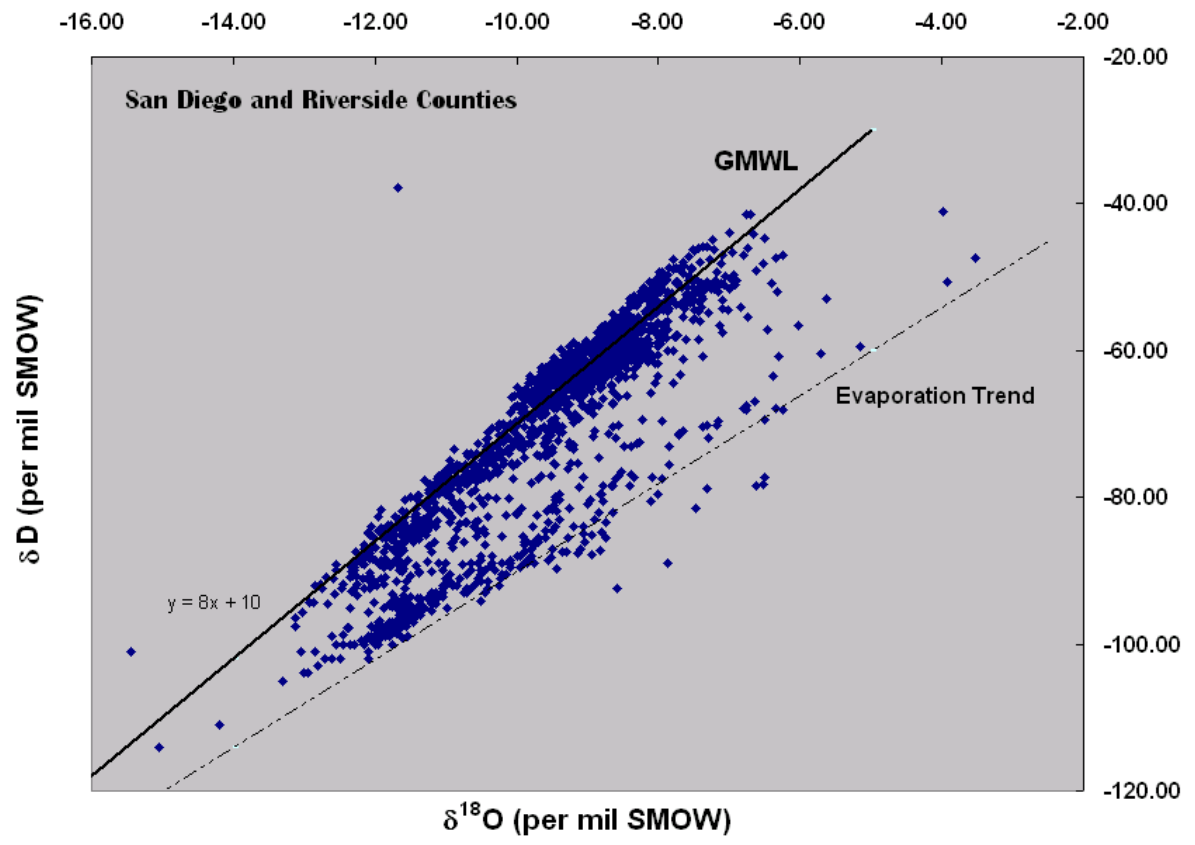

Figure 6.6. The large majority of stable isotope pairs in groundwater samples from San Diego and Riverside Counties fall on or near the Global Meteoric Water Line, with a smaller subset of samples falling along an evaporation trend. 


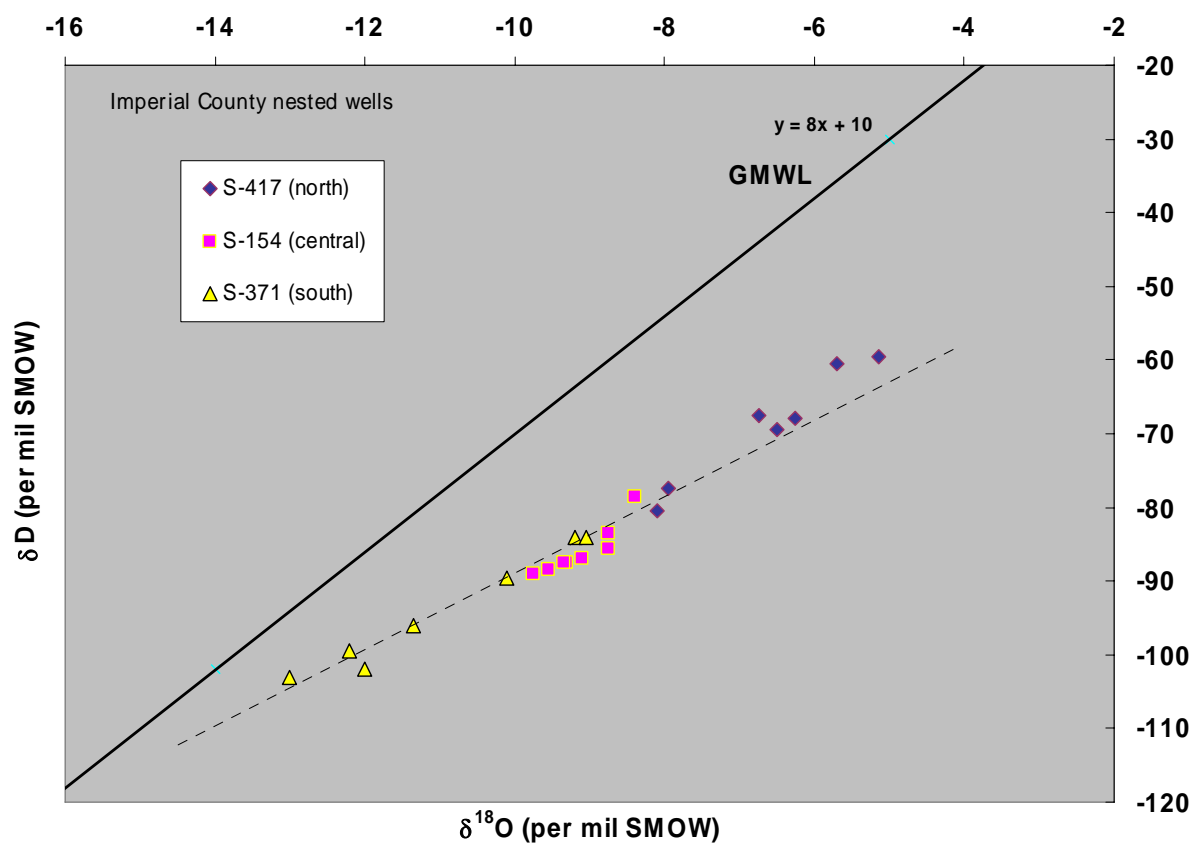

Figure 6.7. All samples from nested wells immediately south of the Salton Sea along the valley axis have stable isotope patterns indicative of evaporated Colorado River water.

Evaporative enrichment decreases with distance away from the Salton Sea.

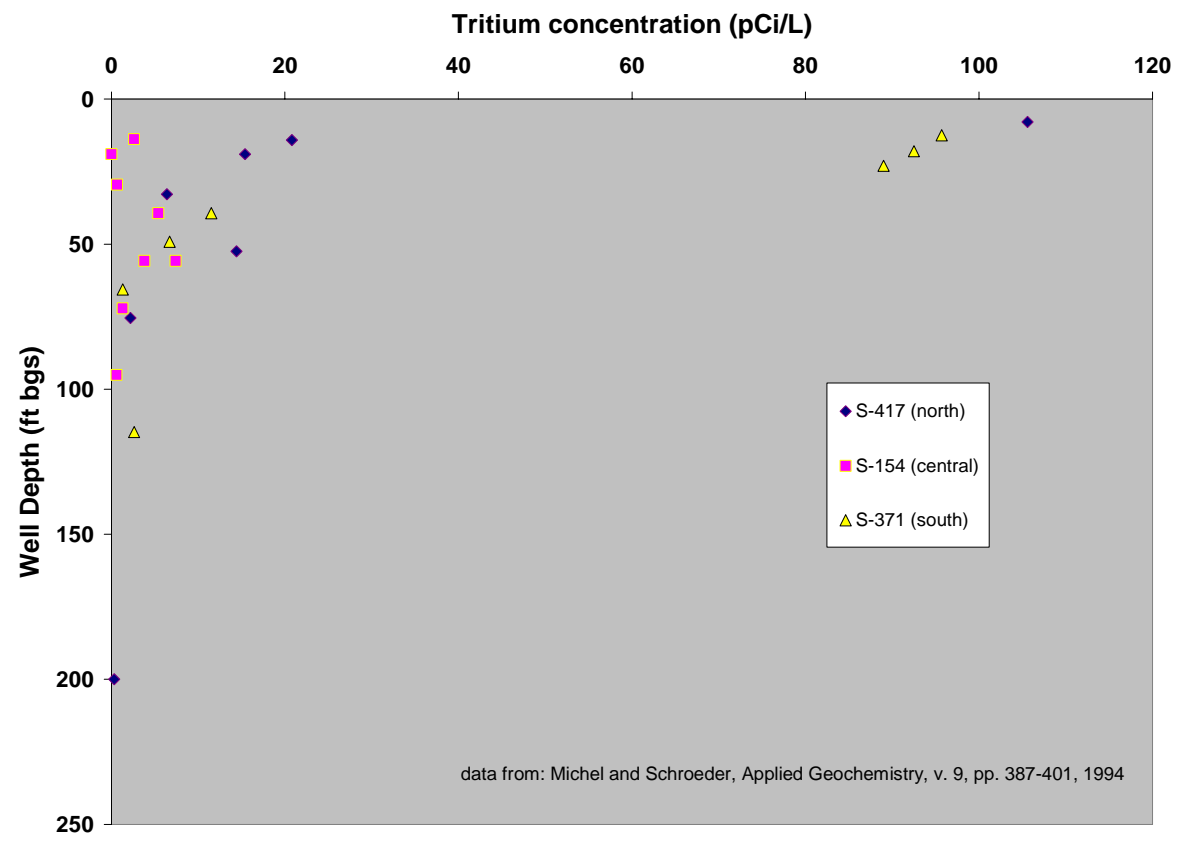

Figure 6.8. Tritium concentrations from nested monitoring wells in three locations to the immediate south of the Salton Sea, along the valley axis. The high concentrations observed in the shallowest sample from the northern location, and the three shallowest samples from the central location are indicative of the presence of post-modern recharge of irrigation water. 
The high tritium waters that have infiltrated in the Salton Sea area make another good tracer of groundwater. On one hand, the high tritium concentrations will have decayed to produce high concentrations of tritiogenic ${ }^{3} \mathrm{He}$, which will allow highly accurate and sensitive analyses of groundwater age. The groundwater ages can be used to delineate recharge zones, to calculate bulk flow rates and recharge rates, to establish mixing relationships between ambient groundwater and recent recharge, and, in combination with flux estimates, to determine the groundwater inventory. On the other hand, tritium concentrations alone may already provide a marker for groundwater recharged during the period of elevated tritium concentrations. Dispersion, decay, and dilution complicate interpretation of tritium by itself, but in simple systems that resemble "piston flow," the high tritium concentrations may be preserved in groundwater. The limited data available, from Michel and Schroeder (1994) suggest that at the time of sampling (1989), elevated tritium was present only in shallow samples from the northern and central locations described in the previous section (Figure 6.8). This observation is interpreted to mean that infiltration of irrigation water reaches down only a maximum depth of $23 \mathrm{ft}$. in this area along the valley axis. This limited, shallow penetration of recent recharge is, in turn, attributed to the presence of extensive low permeability (clay) units along the central portion of the valley. The extent of recent recharge adjacent and away from unlined portions of the All American Canal is not well determined and should be a chief topic of future research.

\subsubsection{Other Tracers used for Groundwater Dating and Source Identification}

There are a number of other stable and radioactive compounds that may be employed to age-date groundwater or determine its source or flow pathway. They may be of used, for example, if water samples are "tritium dead" - that is, if the age appears to be greater than 50 years. They may also be used to assess to what extent specific kinds of water-rock interaction shave occurred along a flow pathway, or as a means to detect co-contaminant signatures from "bomb pulse" atmospheric releases or other contemporary atmospheric components (such as volatile organic compounds). A summary of some of these techniques is provided in Appendix E.

\subsection{Sampling Trips}

The sampling effort was carried out in a series of two visits to Imperial County during the weeks of April 23-26 and June 23-27, 2007. Figure 6.9 shows a map of the East Mesa area with wells identified for potential sampling before the effort began, those found or sampled during the first week, and those targeted for sampling the second week.

As ultimately realized over both weeks, 19 sampling locations were visited (18 wells and the All American Canal at Drop 1) from which water samples were collected from 13 (Table 6.1, Figure 6.10). On the ground, sampling efforts were impeded by the inability to find wells or inaccessibility issues, as with locks or gates that prevented well access to wells. In a more general sense, sampling efforts were restricted by an overall lack of wells consistent with the sampling strategy outlined above.

Groundwater samples collected from the 12 wells and the All American Canal at Drop 1 were analyzed (Table 6.2). The results are discussed in the next section. 


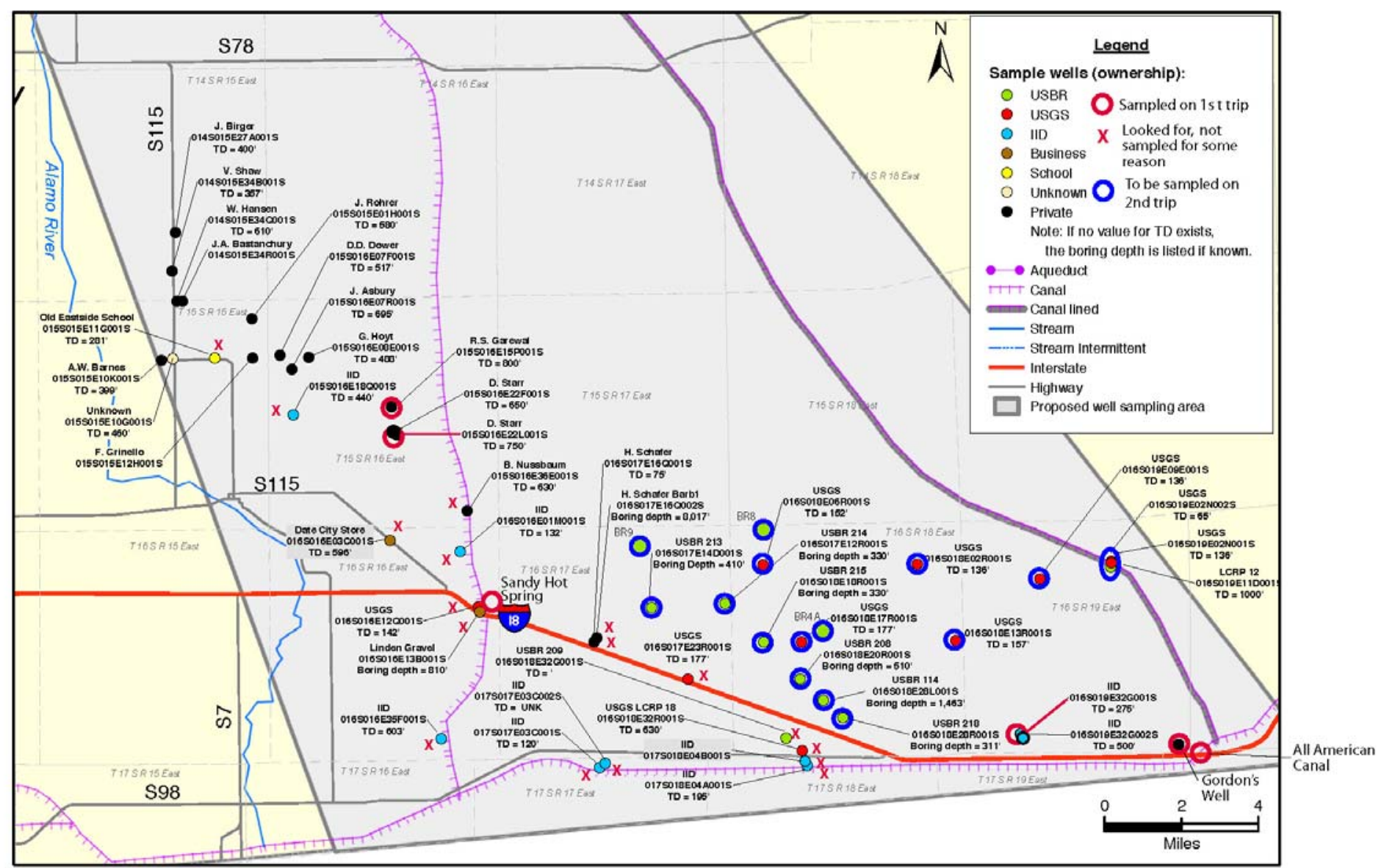

Figure 6.9: Close up map of the East Mesa area showing wells approached and sampled on the first sampling trip (of April 23-26, 2007) and those wells proposed for sampling on the second trip (June 23 to 27, 2007) 
Table 6.1: Physical characteristics of 19 wells visited during on the sampling trips to Imperial Valley on April 23-26 and June 23-27, 2007. Water samples only collected from 13 highlighted wells. Subsequent analyses are shown in Table 6.2

\begin{tabular}{|c|c|c|c|c|c|c|c|c|c|c|c|}
\hline \multirow{2}{*}{$\begin{array}{c}\text { LLNL } \\
\text { Sample } \\
\text { ID }\end{array}$} & \multirow{2}{*}{ State Well ID } & \multirow{2}{*}{$\begin{array}{c}\text { Agency and } \\
\text { Well ID or Well } \\
\text { Owner }\end{array}$} & \multicolumn{2}{|c|}{$\begin{array}{c}\text { GPS Latitude } \\
\text { And Longitude }\end{array}$} & \multirow{2}{*}{$\begin{array}{c}\text { GPS } \\
\text { Casing } \\
\text { Elevation } \\
\left(m \mathrm{ASL}^{\mathbf{1}}\right)\end{array}$} & \multirow{2}{*}{$\begin{array}{c}\text { Casing } \\
\text { Height } \\
\text { (ft } \\
\mathbf{A G S}^{2} \text { ) }\end{array}$} & \multirow{2}{*}{$\begin{array}{c}\text { Water } \\
\text { Level } \\
\text { Depth } \\
\text { ft, } \text { TOC }^{3} \text { ) }\end{array}$} & \multirow{2}{*}{$\begin{array}{c}\text { Water } \\
\text { Level } \\
\text { Depth } \\
\left(\mathbf{f t}, \mathbf{B G S}^{2}\right)\end{array}$} & \multirow{2}{*}{$\begin{array}{c}\text { Total Well } \\
\text { Depth } \\
\left.\text { (ft, } \text { TOC }^{3}\right)\end{array}$} & \multirow{2}{*}{$\begin{array}{c}\text { Top } \\
\text { Screen } \\
\text { interval } \\
\text { (ft } \text { BGS }^{2}\end{array}$} & \multirow{2}{*}{$\begin{array}{c}\text { Bottom } \\
\text { Screen } \\
\text { interval } \\
\left(\text { ft } \text { BGS }^{2}\right)\end{array}$} \\
\hline & & & $\begin{array}{l}\text { Degrees } \\
\text { North }\end{array}$ & $\begin{array}{l}\text { Degrees } \\
\text { West }\end{array}$ & & & & & & & \\
\hline- & - & 78S-AD & 32.7091 & 115.0255153 & 39.45 & 3.75 & 41.3 & 37.55 & 51.79 & & \\
\hline 105114 & 015S016E15P001S & Garawel & 32.8432741 & 115.3096428 & -5.50 & & $\sim 0^{4}$ & & & & \\
\hline 105115 & 015S016E22L001S & Starr & 32.832433 & 115.8071626 & -4.40 & & $\sim 0^{5}$ & & & & \\
\hline 105116 & - & Hot Spring & 32.7654526 & 115.2698057 & 5.65 & & $\sim 0^{4}$ & & & & \\
\hline- & - & BR-6 & 32.7601217 & 115.2664157 & 3.37 & 0.625 & 6.9 & 6.275 & & & \\
\hline 105117 & 016S019E32G001 & IID & 32.716688 & 115.030758 & 39.20 & 1.00 & 42.9 & 41.9 & $500+$ & 40 & 240 \\
\hline 105118 & - & $\begin{array}{l}\text { Gordon's Well } \\
\# 1\end{array}$ & 32.709198 & 114.9637247 & 42.04 & 0.5 & 42 & 41.5 & $\sim 300$ & & \\
\hline 105119 & - & $\begin{array}{l}\text { All American } \\
\text { Canal (Drop 1) }\end{array}$ & 32.712456 & 114.944036 & 39.60 & & & $39.6^{6}$ & & & \\
\hline 105120 & 016S017E14D001S & USBR 213 & 32.76683 & 115.19464 & 20.00 & $\mathbf{1 . 5 0}$ & 6.71 & 5.21 & 420 & & \\
\hline 105121 & 016S018E20R001S & USBR 208 & 32.7382303 & 115.1265534 & 29.66 & 1.48 & 26.81 & 25.33 & 51.4 & & \\
\hline 105122 & 016S018E17R001S & USGS & 32.752625 & 115.1266131 & 33.50 & 1.82 & 29.21 & 27.39 & $\sim 29.82^{7}$ & 155 & 157 \\
\hline 105123 & 016S018E18R001S & USBR 215 & 32.75238884 & 115.1438433 & 33.22 & 1.54 & 23.81 & 22.27 & 325 & & \\
\hline 105124 & - & USBR $215{ }^{66} \mathrm{SE}^{98}$ & & & & 1.65 & 27.68 & 26.03 & 49.6 & & \\
\hline 105125 & 016S018E28R001S & USBR 218 & 32.723645 & 115.1099741 & 35.54 & 1.71 & 16.82 & 15.11 & 316 & & \\
\hline 105126 & - & USBR 218 "SE" 9 & 32.7234944 & 115.1092993 & 30.17 & 1.71 & 22.9 & 21.19 & 48.5 & & \\
\hline- & - & Unknown & 32.78122 & 114.99357 & & 2.68 & Dry & & $36.37^{10}$ & & \\
\hline- & - & $78 \mathrm{~S}-\mathrm{W}$ & 32.793023 & 115.0272 & 35.35 & 3.08 & Dry & & 39.6 & & \\
\hline- & - & $78 \mathrm{~S}-\mathrm{V}$ & 32.795356 & 115.034337 & 30.00 & 1.40 & Dry & & 18.35 & & \\
\hline- & - & Unknown & 32.7234107 & 115.1264384 & 34.92 & 1.90 & 25.22 & 23.32 & 52.55 & & \\
\hline
\end{tabular}

${ }^{1} \mathrm{ASL}=$ Above mean Sea Level, ${ }^{2}$ AGS, BGS = Above or Below Ground Surface, ${ }^{3} \mathrm{TOC}=\left(\right.$ from) Top of Casing, ${ }^{4}$ Artesian flow conditions, ${ }^{5}$ Possible artesian flow conditions, ${ }^{6}$ Canal water elevation, ${ }^{7}$ Could not get the tag line past this depth, ${ }^{8}$ Twin well found 40 feet SE of USBR 215 , ${ }^{9}$ Twin well found SE of USBR 218, painted red, ${ }^{10}$ Soft bottom 


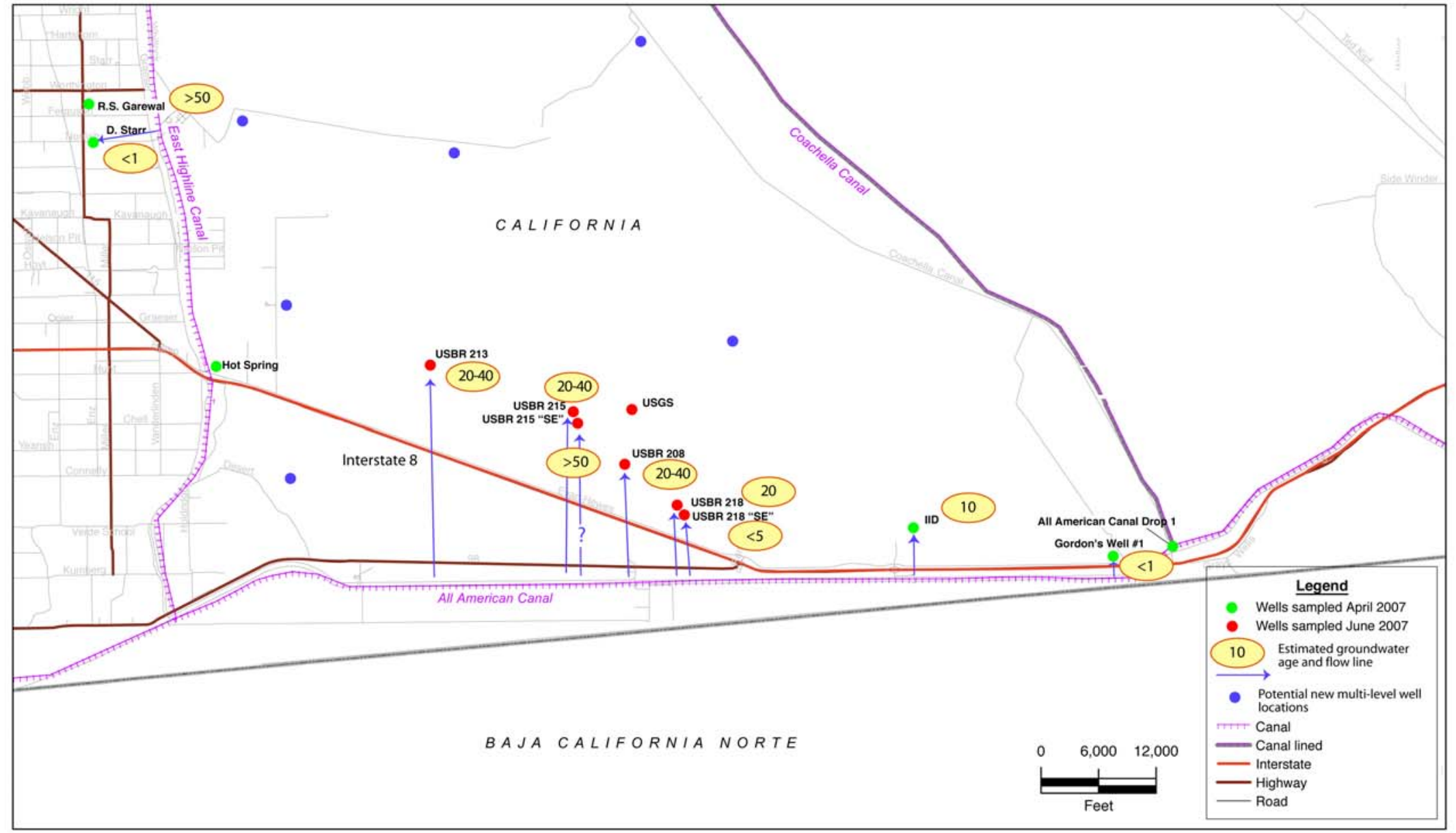

Figure 6.10: Close up map of the East Mesa area showing wells from which samples were ultimately collected on the sampling trips of April 23-26 and June 23-27, 2007). Measured groundwater ages and inferred flow paths also indicated for some of the locations. 
Table 6.2: Groundwater analyses conducted on samples taken from 13 of the 19 sites visited during on the sampling trips to Imperial Valley on April 23-26 and June 23-27, 2007. Physical characteristics of all wells are shown in Table 6.1.

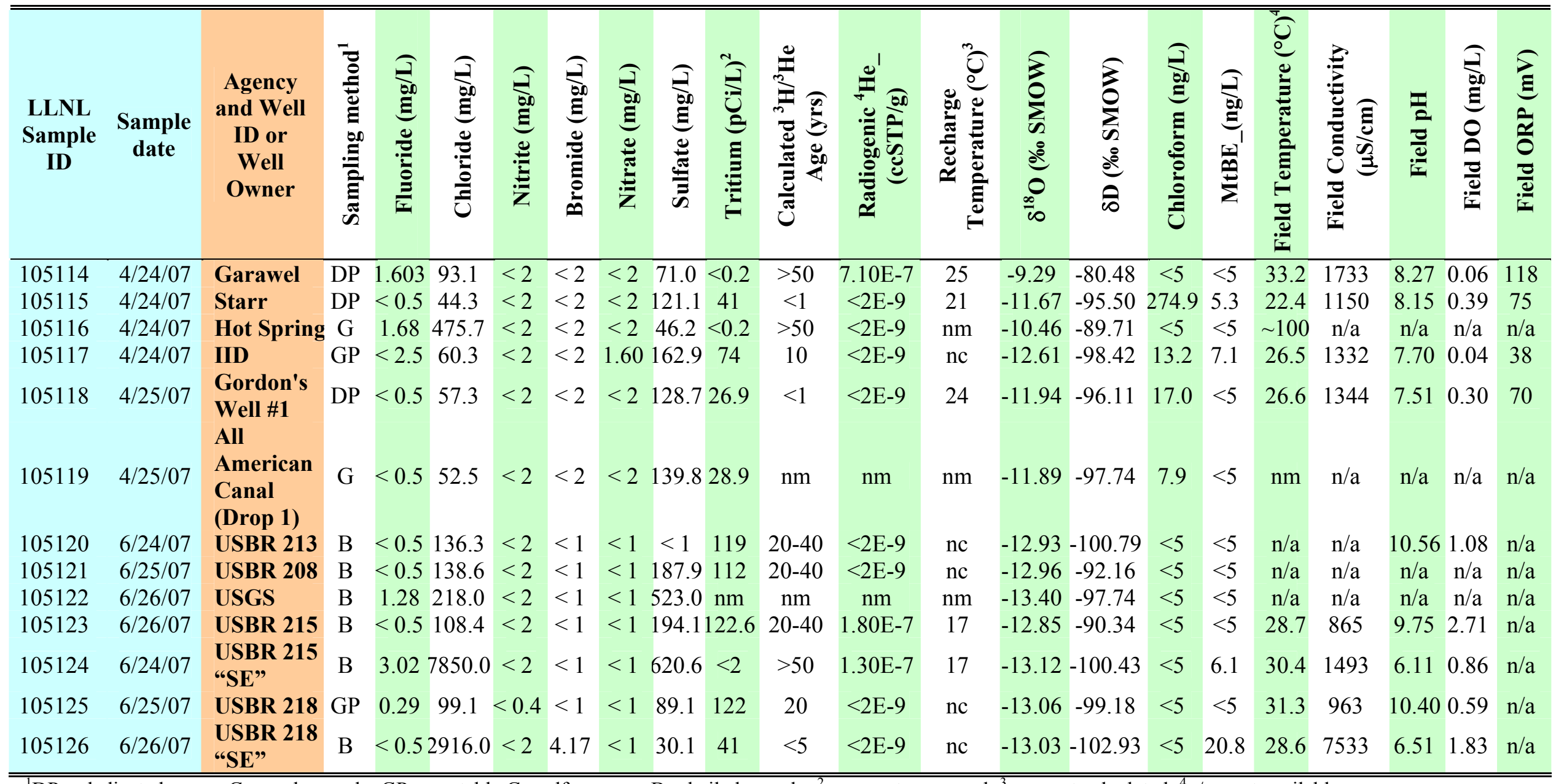

${ }^{1} \mathrm{DP}=$ dedicated pump, $\mathrm{G}=$ grab sample, GP = portable Grundfos pump, B = bailed sample; ${ }^{2} \mathrm{~nm}=$ not measured; ${ }^{3} \mathrm{nc}=$ not calculated; ${ }^{4} \mathrm{n} / \mathrm{a}=$ not available 


\subsection{Sampling Results and Interpretation}

Groundwater samples were collected from 12 wells during two sampling trips made to the Imperial Valley on April 23-26 and June 23-27, 2007, and an additional sample was obtained from the All American Canal at Drop 1. Results of isotopic and chemical analyses performed at LLNL are shown in Table 6.2 and on Figures 6.11-6.14. As mentioned previously, remote well locations, unknown or unfavorable well construction details, and a dearth of monitoring wells with short screened intervals placed severe limitations on both sample integrity and on spatial coverage of the sampling area. Despite these difficulties, the opportunity to sample wells in the heretoforeunexplored East Mesa area for constituents that give direct information about the source and timing of recharge resulted in the acquisition of new and pertinent information. Access to additional wells in the East Mesa area, especially wells that can be pumped, would greatly enhance future studies of this type.

Tritium concentrations were measured in 12 of 13 samples (well USGS E17R1S did not produce enough water for a tritium determination). Only three wells produced water that is 'tritium dead', indicating that the water has not been in contact with the surface reservoir of tritium for more than 50 years. Not surprisingly, the hot spring sample that emanates from the deeper geothermal in the basin is in this category. A sample from the shallow borehole at USBR 215 has a tritium concentration of less than $1 \mathrm{pCi} / \mathrm{L}$, perhaps because the well taps a perched zone that is not exchanging with the deeper flow system. One of the two private supply wells sampled near Holtville ("Garawel") is likewise devoid of tritium, consistent with previous findings (Michel and Schroeder, 1994), suggesting that agricultural return water does not penetrate below the shallow clay units in the central part of the valley. This well showed multiple lines of evidence that it draws a component of water from the deep aquifer system, including an elevated water temperature $\left(33^{\circ} \mathrm{C}\right)$.

The tritium concentration measured in water from the All American Canal (AAC) at Drop 1 $(28.9 \mathrm{pCi} / \mathrm{L})$ is in the range of the expected concentration for Colorado River watershed runoff (33 to $38 \mathrm{pCi} / \mathrm{L}$ ). Guay et al. (2006) report a tritium value for the lower Colorado below Imperial dam in 2002 of $34.1 \mathrm{pCi} / \mathrm{L}$. Variability in the tritium concentration of the canal water over the past few years is likely in the range $25-40 \mathrm{pCi} / \mathrm{L}$.

Results for groundwater ages (which are related to tritium concentrations) fall into three groups:

1. Water recharged very recently, within the last year or two;

2. Water recharged from 10 to 40 years ago, and

3. Water recharged significantly longer than 50 years ago.

As discussed above, two of the three samples devoid of tritium are derived from the deep geothermal system. For samples containing tritium, reliable groundwater ages could be determined from only a few wells (Gordon's Well \#1, "IID”, “Starr”, and USBR 215). Unfavorable well construction or well location did not allow for pumping of the remaining wells, so they were bailed. Very high chloride concentrations, acidic $\mathrm{pH}$ values, and dissolved gas patterns consistent with air equilibration (Table 6.2) indicate that these wells were not purged and that dissolved noble gas samples (required to determine groundwater age) were compromised. 
A well constrained age of $<1$ year was determined for Gordon's Well \#1, which has a total depth of approximately $300 \mathrm{ft}$. The tritium concentration, major ion composition, and $\delta^{18} \mathrm{O}, \delta \mathrm{D}$ values are nearly identical to those of the AAC sample, providing ample evidence for the rapid recharge of canal water to this well. Similarly, the "Starr" well's chemical and isotopic characteristics are a close match to those of the AAC water, and the calculated groundwater age is $<1$ year. The "Starr" well is directly adjacent to a local irrigation canal and likely receives recharge due to leakage from it. A third well, USBR 218 "SE", has a tritium concentration $(41.1 \mathrm{pCi} / \mathrm{L})$ that likewise points to recent recharge. A very low-level detection of MtBE is further evidence for recharge within the last ten years at this well.

An important data point comes from the "IID" well screened over an interval between 40 and $240 \mathrm{ft}$ deep. A well-constrained mean age of ten years, a tritium concentration of $73.6 \mathrm{pCi} / \mathrm{L}$, and a low-level MtBE measurement provide evidence for relatively rapid transport of canal leakage at this location. This sample has somewhat higher concentrations of major ions than water from the AAC or Gordon's Well \#1, for example, which is likely the result of minor water-rock interaction during transit. It also plots slightly above the main evaporative trend on the plot of stable isotopes (Figure 6.11) - a result discussed further below.

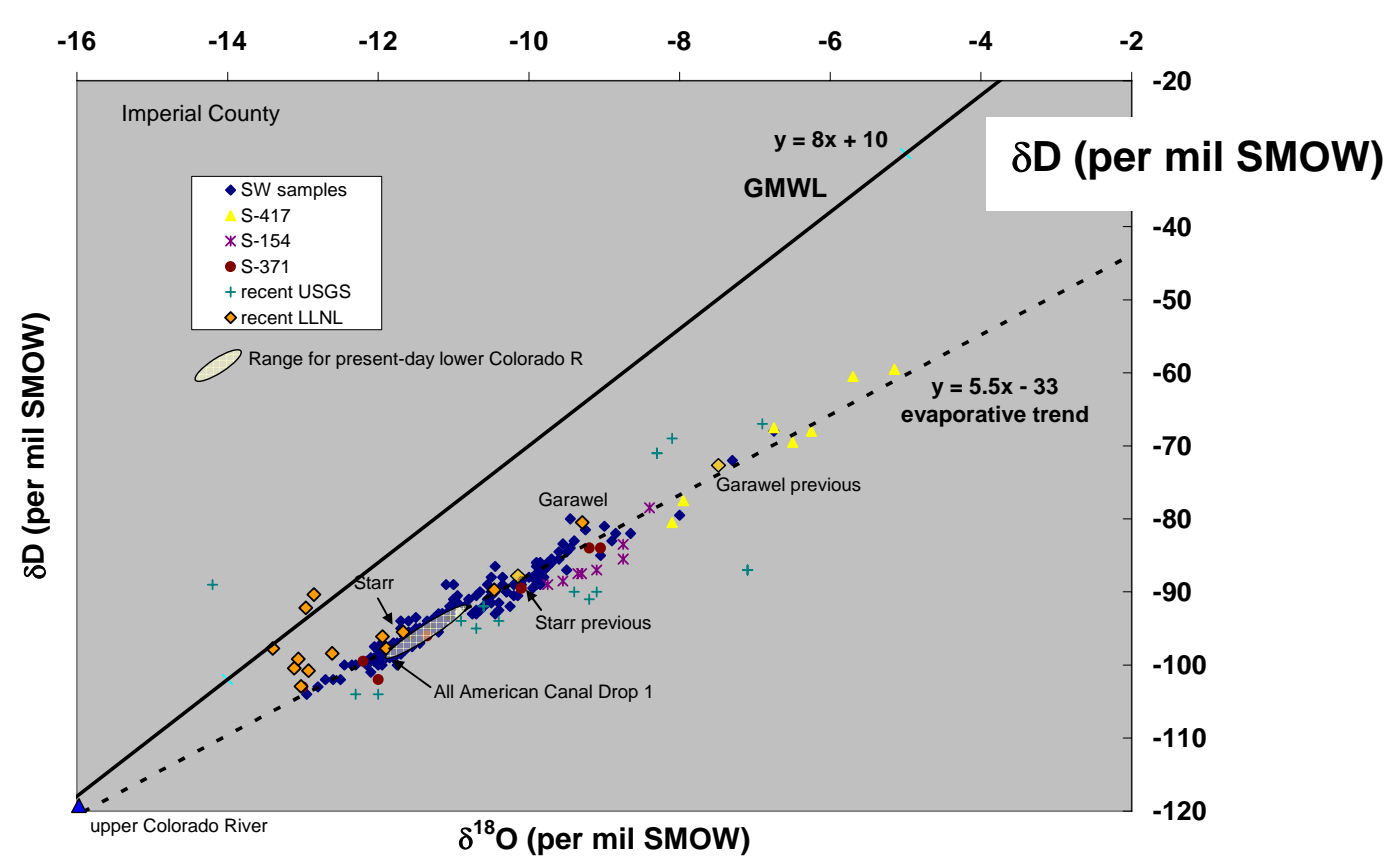

Figure 6.11. Same as plot in Figure 6.5, along with data recently acquired by LLNL (locations shown in Figure 6.2). Some East Mesa wells plot above the evaporative trend on which all previous surface water and groundwater samples from the Salton Sea area fall.

Four wells in the central portion of the study area have tritium concentrations between 112.3 and $122.6 \mathrm{pCi} / \mathrm{L}$ (Figures 6.12 and 6.14). These higher tritium concentrations signal the presence of older water, recharged several decades ago. Unfortunately, groundwater ages could not be determined for these samples as dissolved gas collection was not successful. Tritium concentrations 
in precipitation and surface waters were much higher in the past because of atmospheric nuclear weapons testing - concentrations in the Colorado River system were several hundred $\mathrm{pCi} / \mathrm{L}$ (Michel and Schroeder, 1994; Guay et al., 2006). For example, the tritium concentration in the Colorado River at Imperial Dam was about $910 \mathrm{pCi} / \mathrm{L}$ in 1970 . Water that was recharged in 1970 would have a tritium concentration of $114 \mathrm{pCi} / \mathrm{L}$ in 2007 (due to radioactive decay of tritium). The four wells with tritium concentrations in this range therefore likely produce groundwater that recharged several decades ago.

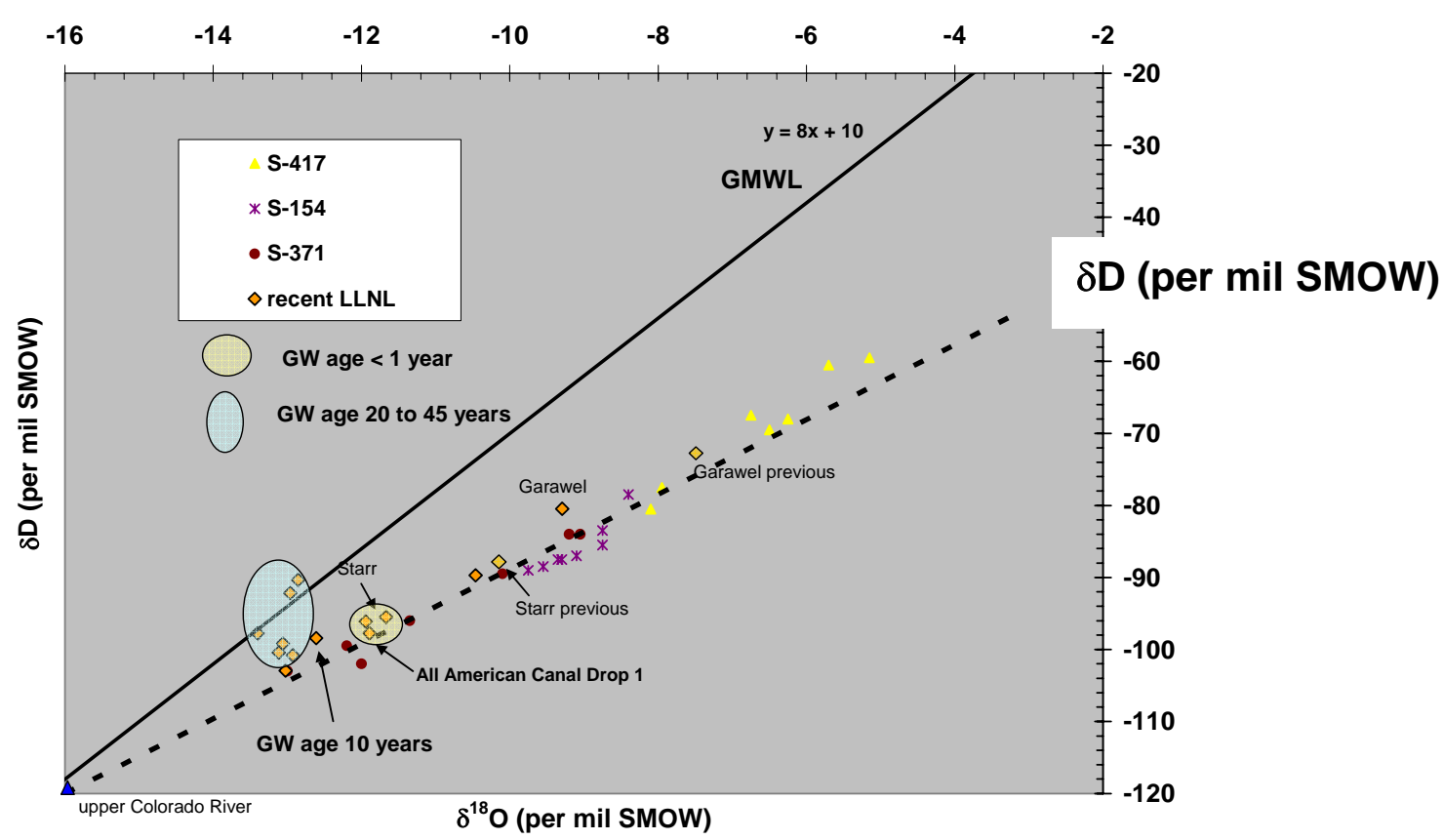

Figure 6.12. Same plot as Figure 6.11, but with groundwater age groupings highlighted by ovals. East Mesa samples with high tritium concentrations, indicating groundwater ages of 20 - 45 years (blue oval), have stable isotope signatures that are less affected by evaporation than previously sampled groundwater from agricultural areas.

Notably, the wells with high tritium concentrations plot in a distinct area on the $\delta^{18} \mathrm{O}$ vs. $\delta \mathrm{D}$ graph (Figure 6.12). While nearly all previously analyzed samples plot on an evaporative trend that includes present day lower Colorado River water sources, these samples plot above that line, ranging up to the Global Meteoric Water Line (GMWL). Some water sources can be ruled out as recharge sources to the wells based on the stable isotope results. Local precipitation in Imperial County would plot on or just below the GMWL, but would be much more enriched in the heavy isotopes (in the range -7 to -9 for $\delta^{18} \mathrm{O}$ and -58 to -70 for $\delta \mathrm{D}$; Guay et al., 2006) than the values observed in these wells. Local precipitation is therefore not contributing significantly to recharge. Lower Colorado River sources have likely fallen on the evaporative trend since 1980 or somewhat earlier (Lake Powell, behind Glen Canyon dam began filling in 1963; the initial filling was completed in 1980). Before the filling of Lake Powell, the lower Colorado River had smaller dams and diversions and would have experienced a significantly shorter residence time in surface reservoirs and less evaporation. This older river would thus have had a stable isotope signature closer to or on the 
GMWL (Figure 6.12). The samples whose stable isotope pairs fall between the GMWL and the evaporative trend ("IID", USBR 213, USBR 215 "SE", and USBR 218) comprise mixtures of the two water types and likely have intermediate groundwater ages. Although present day (unevaporated) upper Colorado River water is more depleted in the heavy isotopes than these mixed age well waters, historical analyses of stable isotopes in the lower Colorado system plot in the range observed in these well waters (Guay et al., 2006).

Therefore, while the stable isotope signatures of the these well waters indicate recharge of old, less evaporated lower Colorado river water, their tritium concentrations indicate that this recharge took place after emplacement of at least some of the dams and the AAC and during a time of high tritium fallout from atmospheric weapons testing, with a significant component of recharge dating to the period 1960-1980. Because these samples contain high tritium concentrations (and for the few samples with dissolved gas results, low radiogenic ${ }^{4} \mathrm{He}$ concentrations), the presence of a significant component of paleowater (e.g., recharged during the cooler, wetter Pleistocene period) is not supported by the data. In comparing these results with those of Michel and Schroeder (1994), one sees that tritiated (decades-old) water penetrates to much greater depth in the East Mesa study area compared to the central valley where irrigated agriculture dominates the landscape (Figure 6.14). Alteration of the stable isotopes by extreme evaporation in agricultural areas, evident in the plot of $\delta^{18} \mathrm{O}$ vs. depth (Figure 6.13), likewise distinguishes the deep penetration of less-evaporated water in the East Mesa desert from shallow penetration of highly evaporated water in the central valley.

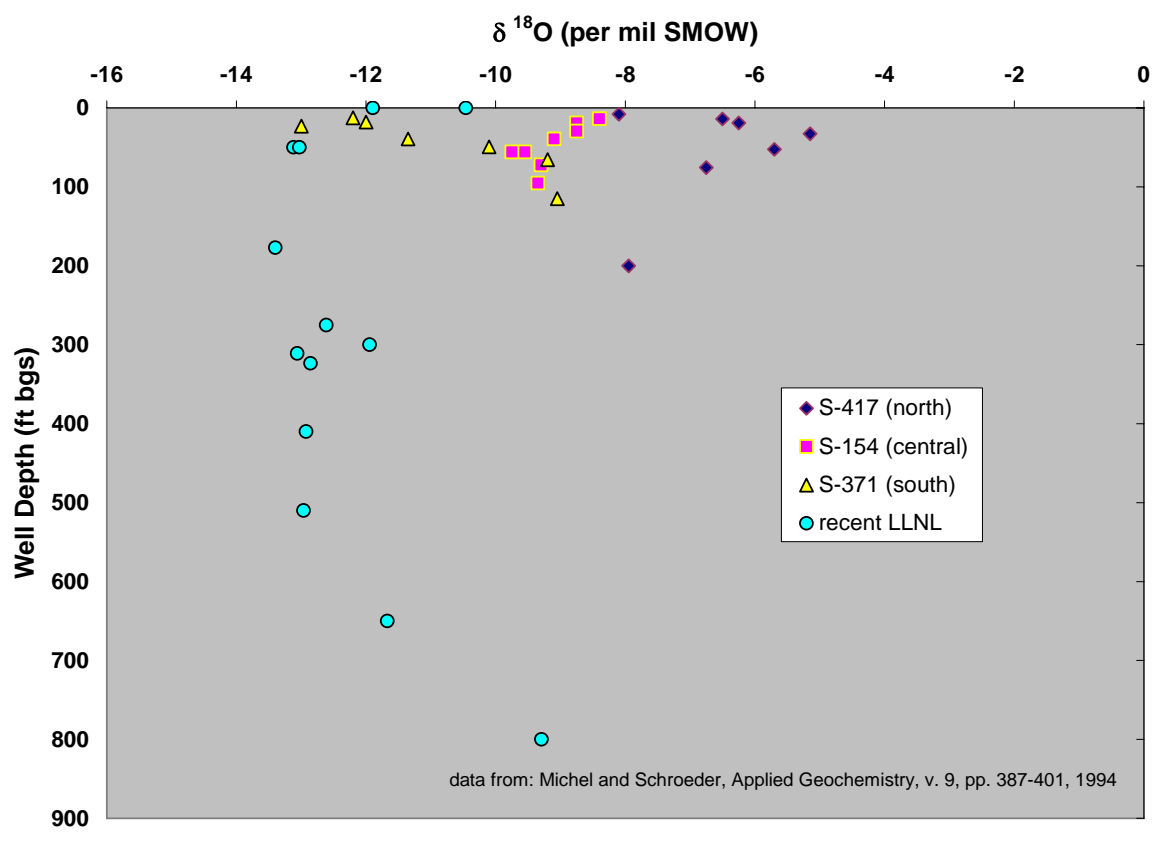

Figure 6.13. Light stable oxygen isotope ratios in recently sampled deep wells indicate deeper penetration of water unaffected by agriculture (less evaporated) in the East Mesa area than in the central Salton Sea area.

One further comparison can be made for the two agricultural area wells, "Starr" and "Garawel". In both cases, stable isotope values from 1988-89 (sampled and analyzed by the USGS) 
were significantly more depleted in the heavy isotopes (i.e., less negative) than our recent results from twenty years later (Figure 6.11). The presence of less evaporated water in recent samples might be the result of a change in agricultural practices whereby irrigation-return flow is preceded by a shorter surface residence time. Alternatively, recharge with a larger component of direct canal seepage (versus irrigation return flow), would exhibit a less evaporated signature. Changes may also be influenced by lower amounts of recharge into the East Highline Canal as a result of the lining of the Coachella Canal in 1979.

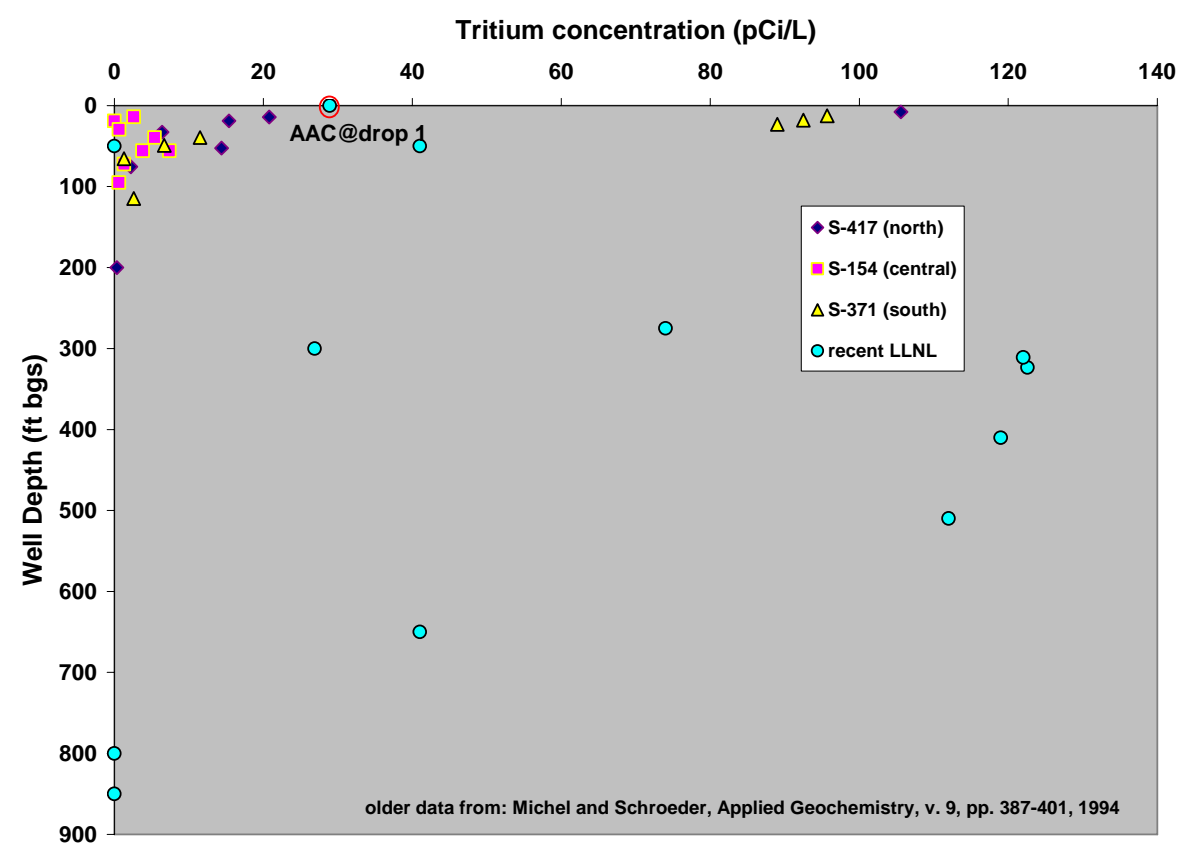

Figure 6.14. Same plot as shown in Figure 6.10, along with data recently acquired by LLNL. High tritium concentrations show penetration of decades old water in deeper wells in the East Mesa area.

\subsection{Future Sampling Opportunities}

The sampling results provided new and useful information about the age and provenance of groundwater in the East Mesa area. However, because the available sampling network was sparse, the density of information was insufficient to provide a clear sense of current and historical groundwater movements in the area. The sampling network could easily be augmented to improve this picture, especially in such a way to provide insights into the flows derived from the AAC leakage, their eventual discharge locations (as into or under the East Highline Canal), interactions with losses from the Coachella Canal that occurred prior to 1979, and their overall contribution to increases in groundwater in storage under the Mesa. Ideally, several multilevel monitoring wells could be developed in one or more areas in the Mesa (e.g., Figure 6.10). Such a network could provide very useful information about the vertical distribution of isotopic signatures at individual locations and, as a result possibly indicate boundaries between Colorado and non Colorado River 
waters, or recent (e.g., AAC leakage) and older waters in the East Mesa area. The depth of such wells could easily extend between 500 and 1,000 ft with multiple sampling ports spaced along their length. In other areas, such multilevel networks have provided very informative results (e.g., Moran and Halliwell, 2003; Moran et al. 2002a,b; 2003; 2005a,b; Tompson et al., 1999). 


\section{Section 7:}

\section{Phase II Groundwater Model Development in the Imperial Valley}

The primary objective of this activity is to complete an initial conceptual development of a new numerical computer model of three-dimensional groundwater flow in the southern half of the Salton Sea Basin and northern portion of the Mexicali Valley in Mexico, as shown in Figure 7.1. This model augments previous groundwater models conducted in the area by Skrivan (1977), Mitten et al., (1988), Fogg (1989), Montgomery Watson (1996), and Tetra Tech (1999).

Full calibration and testing was not a part of this activity, per recommendations of Reclamation staff. Nevertheless, when fully calibrated and tested, the model is expected to allow for

- Analyses of groundwater movements, primarily in the shallower aquifer, between the western mountain ranges, the East Mesa, and the Colorado River, all as a function of recharge, discharge, and historical canal leakage processes,

- Investigations of the impacts of canal lining to groundwater movements in the East Mesa Area,

- Quantitative assessment of the viability and impact of new groundwater extraction opportunities in the mountain front areas along the western perimeter of the basin, extending into the West Mesa area, and the groundwater mound underlying the All American or Coachella Canals in the East Mesa area, as identified in Section 2.4 and Appendix A.

- Engineering assessments of the efficacy of new groundwater banking (ASAR) opportunities in the East Mesa area

Any valuable model of this sort will require substantive, iterative, and ongoing development over its lifetime. The work in this project covers only the initial phase of this effort.

The groundwater model itself was developed using the Groundwater Vistas software (ESI, 2007), which is based upon the widely used Modflow2000 Package (Harbaugh et al, 2000). This model is able to simulate three-dimensional groundwater flow, in either steady or transient scenarios, under saturated, isothermal, and constant density conditions. The model is fundamentally based upon a finite discretization of the underlying mass and momentum balances for saturated groundwater flow (e.g., Bear, 1979), and the package allows for numerous types of boundary and source/sink conditions to be considered, such as those that may represent canal leakage to a deeper water table. 


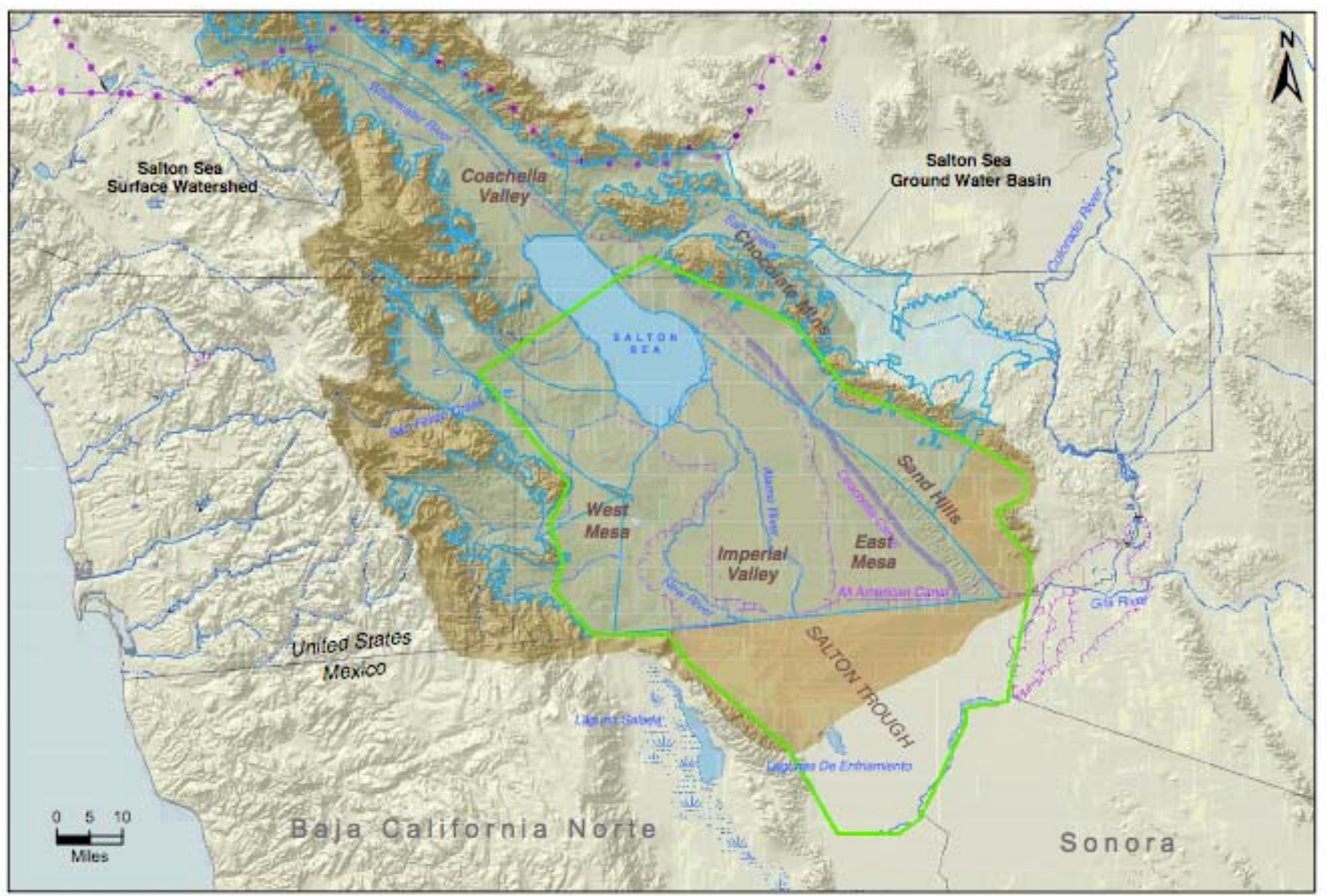

Figure 7.1: Map of the Salton Sea Basin showing the horizontal extent of the proposed 3D groundwater model domain (green), the overall Salton Sea watershed boundary (shaded), and the outlines of the recognized (US) groundwater basins (shaded with blue outlines). 


\subsection{Groundwater Model Specification}

\subsubsection{Model Domain}

As shown in Figure 7.1, the areal extent of the groundwater model domain was chosen to overlay the previously identified groundwater basins in the lower half of the Salton Sea watershed and a portion of their natural extension into the Mexicali Valley in Mexico. Specifically, the model covers the West Salton Sea, Clark-Ocotillo Valley, Borrego Valley and Coyote Wells Valley basins to the west, the Imperial Basin in the center, including its natural extension in Mexico to the Colorado River, and the East Salton Sea and Amos Valley basins to the east. The extension of the domain into Mexico goes beyond the topographic watershed boundary, but allows the lower Colorado River in Mexico to be incorporated as important recharge source for the regional groundwater system. In principal, this would allow for recharge processes in the western part of the basin to be included and studied, as well as current and historical canal leakage under the All American and Coachella canal systems, both having been cited as potentially new opportunities to develop new groundwater resources or ASAR systems in the basin.

The vertical extent of the model domain was chosen to extend from the water table to the bottom of the Imperial formation, just above the of the formal basement or bedrock in the Salton Trough (e.g., Figure 2.3). The inclusion of the full basin depth, as opposed to a thinner segment incorporating shallower alluvial, lacustrine, and delta deposits near the ground surface, was motivated by the desire to include the full basin conceptual model in the flow model to support a potential future need to examine interactions between the shallower and deeper groundwater systems.

That said, because such interactions will not be of primary interest at this stage of the work, the deeper sections of the model may be effectively isolated from the shallower ones through selected parametric specifications in the model. In addition, because non-isothermal conditions and density dependent flow conditions may exist, either at depth or in isolated shallow areas, any analysis of flow in these areas with the Modflow model will be approximate and better reserved for analyses with more capable computer models such as TOUGH2 (Preuss, 1991), NUFT (Nitao, 1995) or FEFLOW (WASY, 2007).

\subsubsection{Model Grid}

In plan view, the model domain ranges from $114.7^{\circ}$ to $116.2^{\circ} \mathrm{W}$ longitude and from $32.2^{\circ}$ to $33.5^{\circ} \mathrm{N}$ latitude, and is approximately 85 miles $(137 \mathrm{~km}$ ) wide (from east to west) and 89 miles $(144 \mathrm{~km})$ long (north to south) at its greatest extents. The entire domain covers an area of 7,615 square miles $\left(19,728 \mathrm{~km}^{2}\right)$ in area. If the inactive cells are neglected, the active area of the model covers 4,100 square miles $\left(10,758 \mathrm{~km}^{2}\right)$.

The model domain has been discretized into an orthogonal grid of $137 \times 144$ square $(1000 \mathrm{~m} \times 1000 \mathrm{~m})$ blocks in the horizontal plane and divided vertically into 11 layers of variable thickness (see below in Section 7.1.3). This process yielded a total of 217,008 computational cells in the overall grid, 118,162 of which are maintained as "active". 


\subsubsection{Model Structure}

The model layers were developed from the three dimensional geologic model of the Salton Sea Trough which is comprised by the Imperial, Palm Springs, Borrego, Brawley, and shallower post-Brawley (alluvium, lacustrine, and delta sediment) formations, as shown in Figure 2.3. The uppermost layer of the numerical model represents the unconfined zone from the surface to the regional groundwater table. All layers below the first were considered to be both saturated and confined (See layer summary in Table 7.1).

Table 7.1: Modflow model layer summary

\begin{tabular}{ccccc}
\hline \hline Layer(s) & Type & Bottom Depth $(\mathbf{m})$ & Material & Geologic Formation(s) \\
\hline 1 & Unconfined & Regional water table & Clay, Sand & Post-Brawley \\
$2-5$ & Confined & 100 & Clay, Sand & Post-Brawley \\
$6-9$ & Confined & 500 & Clay, Sand & Post-Brawley, Brawley \\
10 & Confined & 3,000 & Rock & Palm-Springs and Borrego \\
11 & Confined & $4,000-6,000$ & Rock & Imperial \\
\hline \hline
\end{tabular}

Geologically, the underlying formations do not extend laterally throughout the entire model domain, and areas of discontinuity exist when formations pinch-out at edges or are superseded by underlying formations. To accommodate this numerically, discontinuous zones were extended laterally throughout the domain using thin thicknesses and they are assigned property values of overlying zones. In addition, the lateral extent of the formations south of the US-Mexico border were extrapolated southward, based upon their cross sectional distribution at the border, and pinched in the same way along the lateral (east west) sides of the basin.

As a means to assign material properties to the model, the three-dimensional grid was used to represent the distribution of clays and sands in the Post-Brawley Formation in the uppermost layers $(1-9,0-500 \mathrm{~m})$ where the vertical grid resolution was the finest. The bimodal distribution of clays and sands was inferred from geologic cross sections and well lithology logs that indicate finer clay-type materials to the north and coarser sand deposit to the south, as interpolated with the EarthVision (DGI, 2007) geologic modeling software (Figure 7.2). Once the model layers were developed, the nodal coordinates were back interpolated on the property grid to establish the spatial distribution of sand and clay for the top nine layers. These values were evened out with a smooth-pass filter as a means to remove localized perturbations in the material assignments and associated hydraulic properties (e.g., hydraulic conductivity, porosity). The lower layers were more coarsely resolved and used to represent the Palm-Springs and Borrego (combined) and Imperial Formation rocks. The resulting material assignments for several selected model layers are presented in Figure 7.3. Vertical cross sections of material distributions for all layers are shown in Figure 7.4 . 


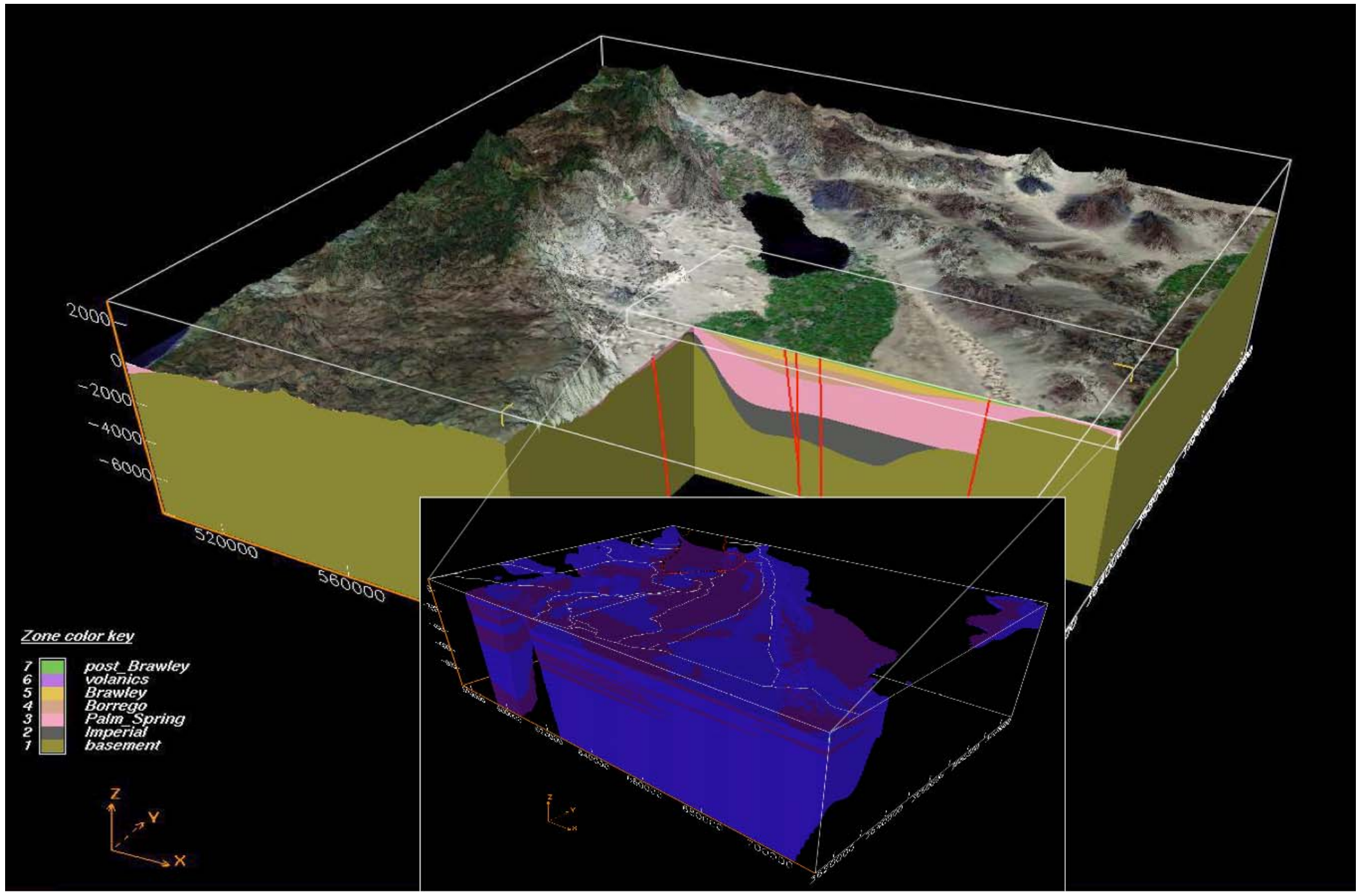

Figure 7.2 A portion of the bimodal (fine clays/coarse sands) distribution of material properties specified within the uppermost layers of the model domain, corresponding largely to layered alluvium, lacustrine, and delta deposits in the post Brawley formation. Fine and coarse structures interpolated from lithologic logs in the water resources database. 

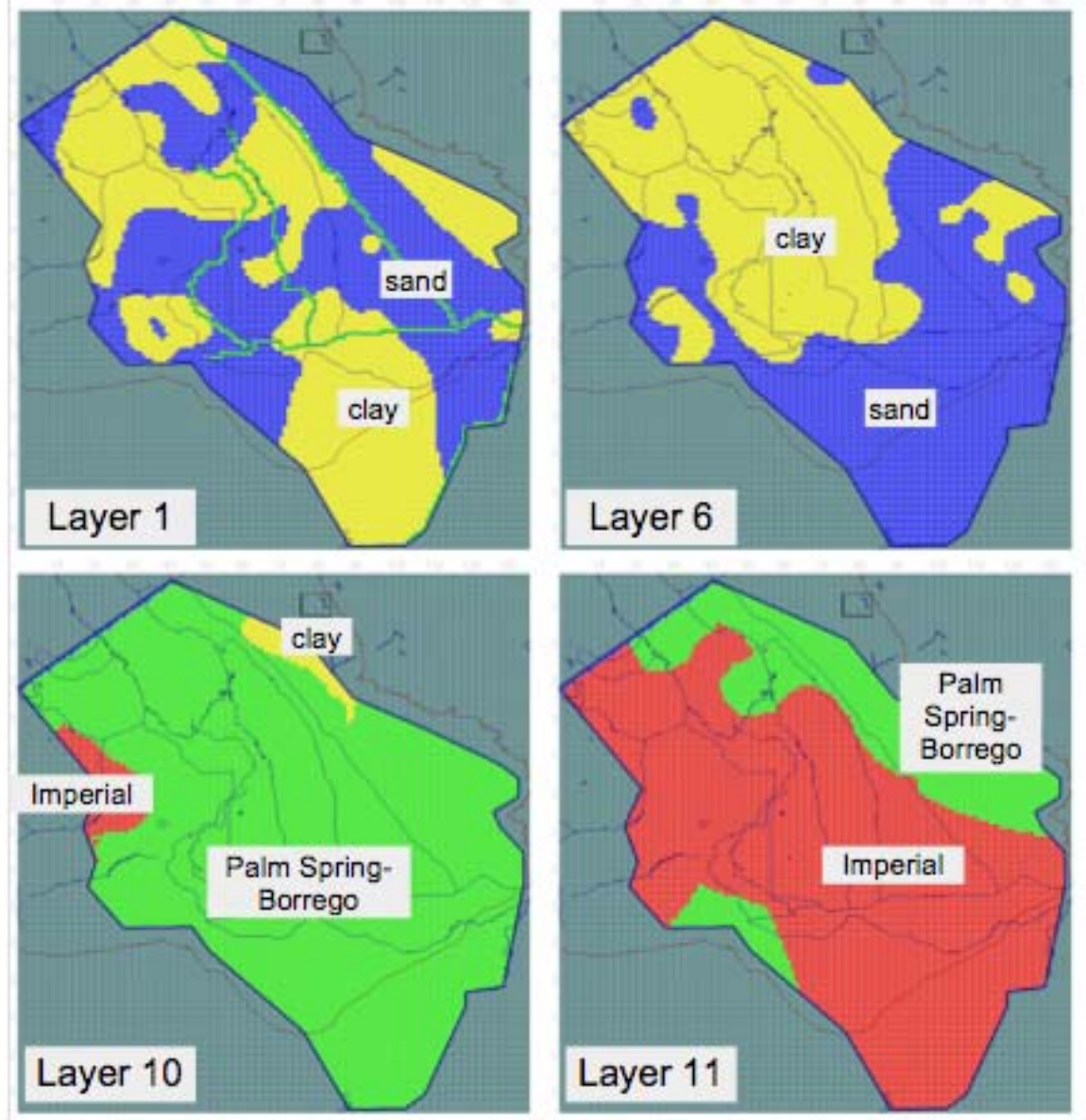

Figure 7.3. Material assignments in selected model layers. Colors correspond to material assignments: Blue $=$ sand; Yellow $=$ clay, Green $=$ Palm Springs - Borrego $($ combined $)$, and Red $=$ Imperial. Teal represents inactive nodes.

Because of data scarcity and to support model efficiency, only four material types have been incorporated into the model at this time. This will be an advantage for future parameter estimation purposes. These include

- Clay and Sand (chiefly distributed in layers 1-9 in the upper Post-Brawley and Brawley Formation)

- Palm Springs-Borrego (combined, chiefly layer 10)

- Imperial (chiefly layer 11) 


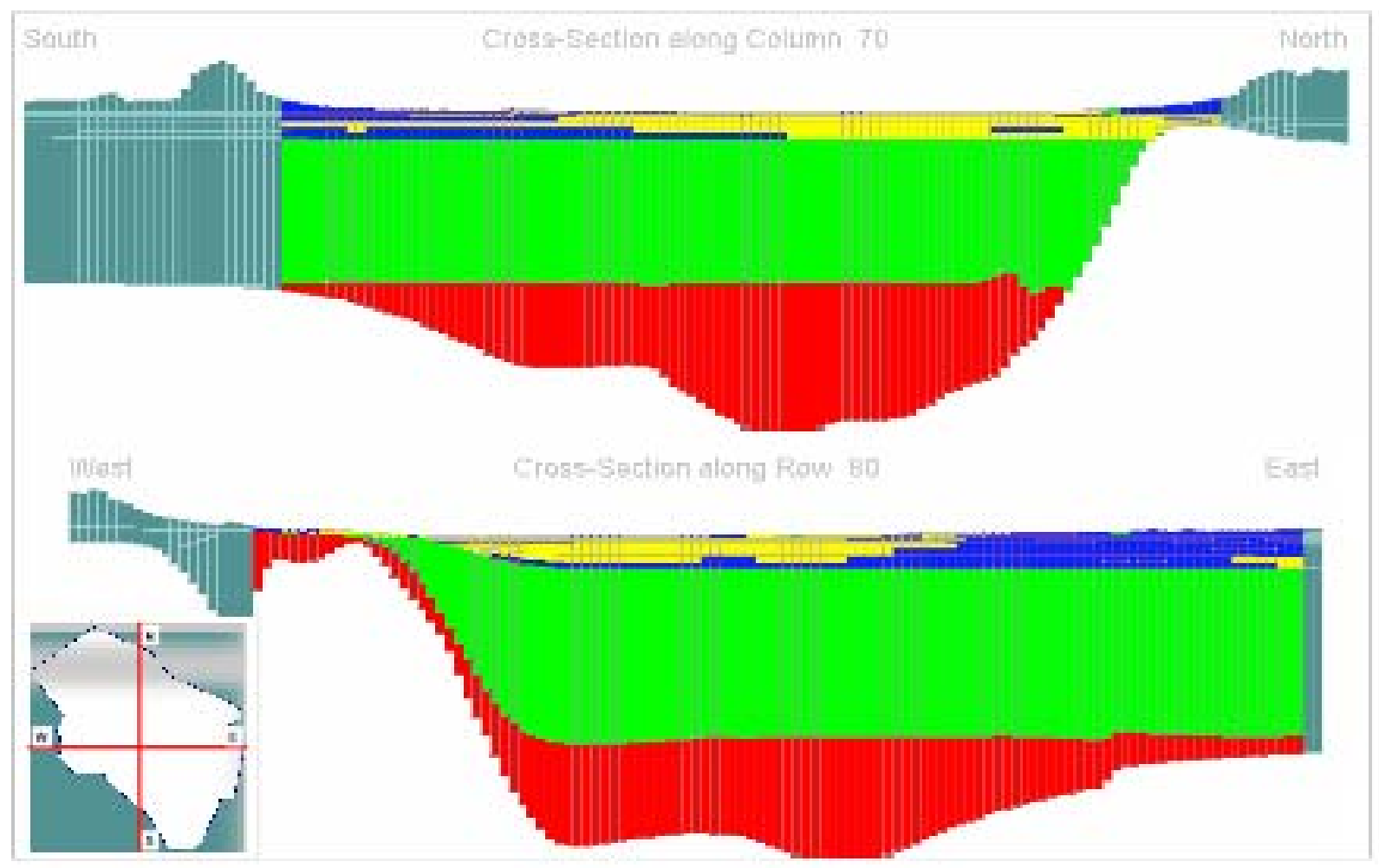

Figure 7.4: Material assignments in the numerical model for a (a) South to North crosssection (and (b) West to East cross-section. Colors correspond to material assignments: Blue $=$ sand; Yellow $=$ clay, Green $=$ Palm Springs - Borrego $($ combined $)$, and Red $=$ Imperial. Teal represents inactive nodes.

\subsubsection{Regional Groundwater Elevation Map}

To develop the bottom surface of the top model layer, a regional groundwater elevation map was generated using 2003 water level data fro, groundwater monitoring wells (Appendix F). To constrain the regional groundwater map, the water surfaces of the lower Colorado River and the Salton Sea were fixed as fixed (potentiometric) surfaces. In addition, several measured data points were removed and supplemented with "control points" to constrain the groundwater elevations and prevent "day lighting" whereby an extrapolated groundwater surface rises beyond the ground surface. A representation of this map is shown in Figure 7.5.

\subsubsection{Boundary Conditions: First Pass}

The model uses constant-head, no-flow, and head-dependant (river) boundary conditions to constrain or otherwise perturb the groundwater flow solution (Figure 7.6). Initially, a constanthead boundary condition was applied at the northern edge of the model domain and along the Salton Sea to simulate an established potentiometric surface that can permit water to flow in or out of the system depending on internally developed flow conditions. Based on Figure 7.5, older regional groundwater maps (Tetra Tech, 1999), and other analyses, evidence indicates that groundwater discharges into the Salton Sea from much of its perimeter. It is also appears that 
groundwater discharges from the naturally recharged Coachella valley basin into the model domain. A constant-head boundary condition was also applied at the southern edge of the model domain along the Colorado River and along portions of the western perimeter boundary. The Colorado River condition will allow for inflows to be drawn as a function of pumping in the Mexicali Valley. The western perimeter boundary conditions form an interface with higher recharge areas in the West Mesa and upper San Felipe Creek watersheds. No-flow conditions were naturally established in all other perimeter boundary locations that abut the perimeter mountain ranges and at the intersections between active model cells and the lower basement or bedrock locations.

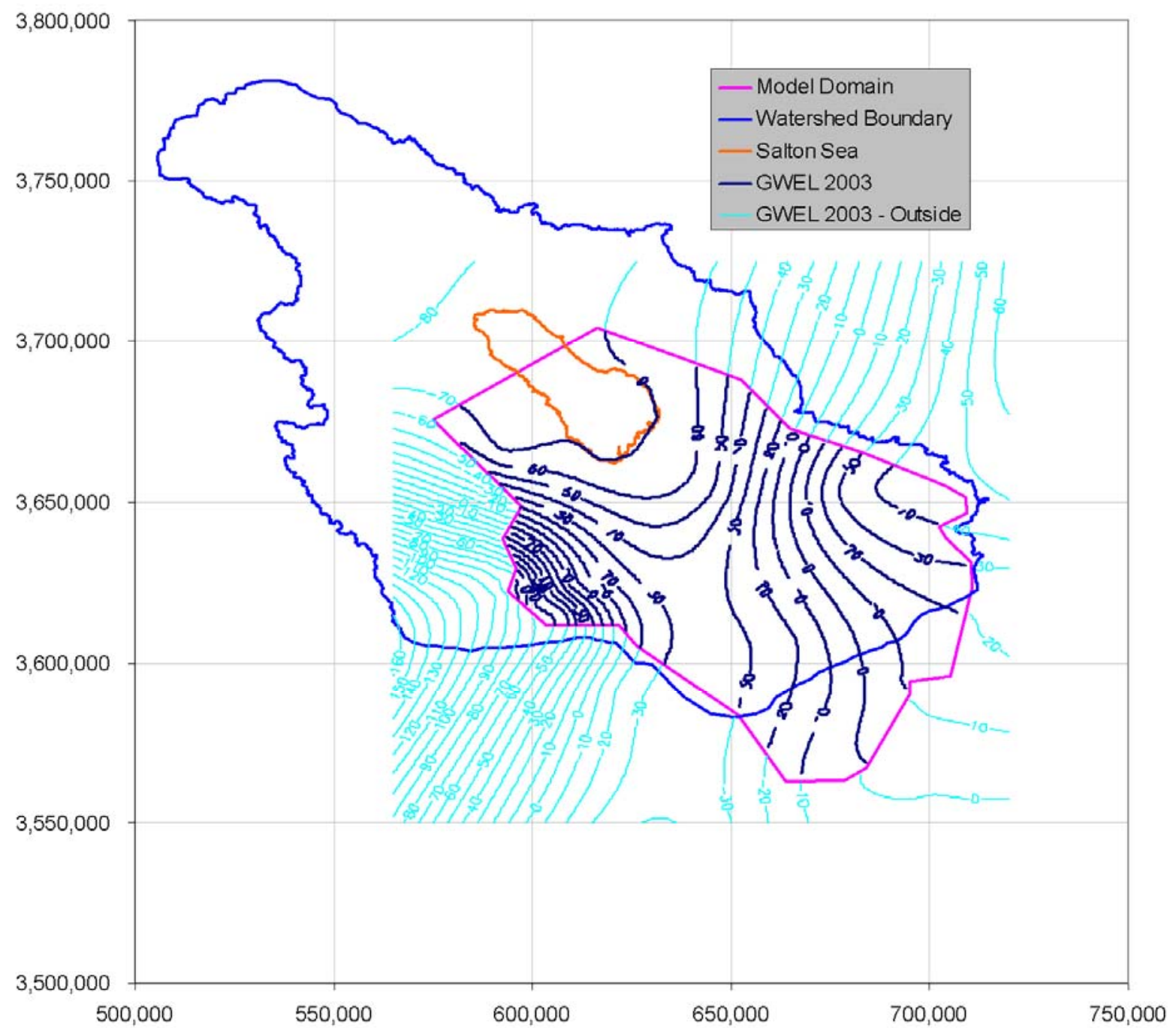

Figure 7.5: Approximate groundwater elevation map (c2003) developed from data in Appendix F. Representations in Mexico are approximate. 


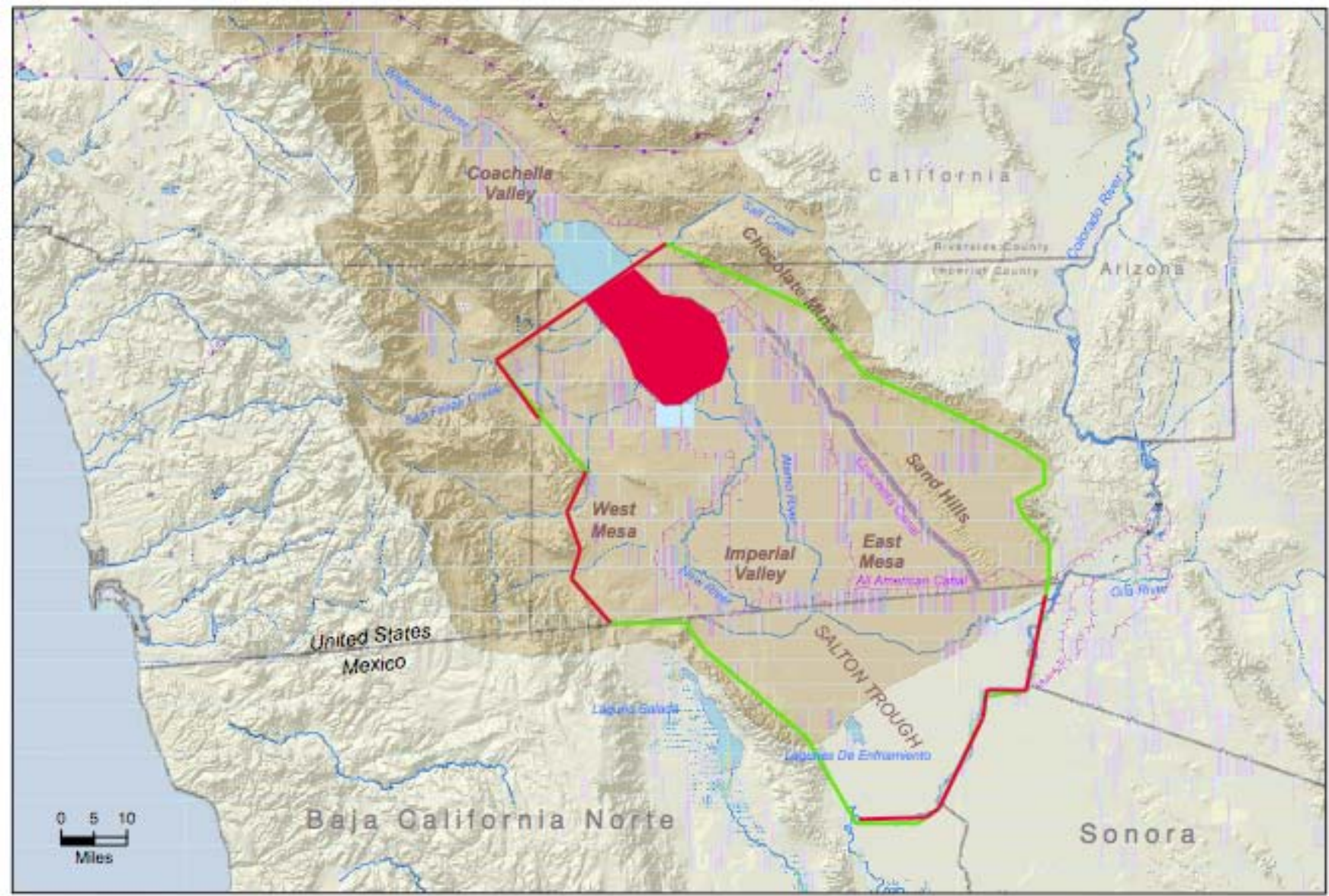

Figure 7.6: Upper layer model boundary conditions: $\operatorname{Red}=$ Constant head and Green - No flow. 


\subsubsection{Recharge Estimates}

As described in Section 2.3.2, the primary source of groundwater recharge in the model domain will be Colorado River, either directly, as a result of a connection with the river along the southern model border in Mexico, or indirectly as a result of water losses from irrigation and imported water canals. Precipitation is regarded here as a secondary source of groundwater recharge, as is any direct connection with the Salton Sea.

An upper bound for the net irrigation losses to recharge in the 525,000 acres of irrigated cropland in the Imperial Valley is $250,000 \mathrm{AF} / \mathrm{y}$ (or $0.48 \mathrm{ft} / \mathrm{y}$ per acre), as described in Table 2.5. This value is uncertain, and could easily be smaller, or close to zero, if the balance between the ET and tile drain network efficiency are more closely matched (Appendix A). Similarly, in Mexico, irrigated land and associated tile and canal drainage networks are widely prevalent in the model domain (e.g., Figure 4.10), and a similar upper bound rate of recharge might be considered in the model for the irrigated lands in Mexico.

Canal losses along the All American Canal, Coachella Canal and New River in the US are discussed in Sections 2.1.1 and 2.3.3 and are summarized in Table 2.2. Although the AAC losses are significant, the CC losses may potentially be neglected, as they are believed to contribute primarily to the shallow phreatophyte wetland areas immediately below the canal, as opposed to the broader groundwater regime. No information regarding analogous canal losses in Mexico is currently available.

A precipitation analysis in Appendix A suggested that approximately 4,249 AF/y of precipitation-excess occurs on an average annual basis within the model domain (Table A.4) ${ }^{7}$. This figure reflects an extrapolation of US data across the border, within the portion of the model domain in Mexico. It can also be considered as a lower bound estimate of the precipitation-based recharge, as it excludes the presence of precipitation-based runoff originating in higher terrain outside the model domain. This figure represents less than $10 \%$ of the annual precipitation excess estimated for all groundwater basins in the Salton Sea Watershed, and less than 1\% of precipitation excess estimated for the entirety of the Salton Sea Watershed as a whole.

Table 7.2 summarizes the recharge information that will initially be used to drive the model. Recharge in the irrigated areas of the Imperial Valley beyond the capture effects of the tile drains, is uncertain, and a " 0 " specification will be initially used in the model, and in the irrigated areas of the Mexicali Valley by extrapolation. in Mexico.

${ }^{7}$ This figure reflects an extrapolation of US data across the border, within the portion of the model domain 
Table 7.2: Groundwater recharge rates and characteristics specified in the numerical model

\begin{tabular}{|c|c|c|c|c|c|c|c|}
\hline Feature & $\begin{array}{c}\text { Total recharge } \\
\text { rate } \\
{\left[\mathbf{m}^{3} / \mathbf{d}\right]}\end{array}$ & $\begin{array}{l}\text { Width } \\
\text { [m] }\end{array}$ & $\begin{array}{l}\text { Depth } \\
\text { [m] }\end{array}$ & $\begin{array}{l}\text { Bed } \\
{[\mathrm{m}]}\end{array}$ & Cells & $\begin{array}{l}\text { Conductivity } \\
\qquad[\mathrm{m} / \mathrm{d}]^{1}\end{array}$ & $\begin{array}{l}\text { Conductance } \\
\qquad\left[\mathrm{m}^{2} / \mathrm{d}\right]^{2}\end{array}$ \\
\hline $\begin{array}{l}\text { All American Canal } \\
(\mathrm{AAC})^{3-5}\end{array}$ & 318,361 & 53.3 & 4.12 & 1.0 & 105 & 0.0111 & 593.05 \\
\hline New River (NR) ${ }^{6-8}$ & 23,656 & 20.6 & 3.5 & 1.0 & 100 & 0.0033 & 67.49 \\
\hline $\begin{array}{l}\text { Coachella Canal } \\
\text { Lined (CC-L) }\end{array}$ & $\sim \mathbf{0}$ & 4.9 & 3.4 & 1.0 & 117 & 0.0026 & 12.84 \\
\hline $\begin{array}{l}\text { Coachella Canal } \\
\text { Unlined (CC-U) }\end{array}$ & $\sim 0$ & 4.9 & 3.4 & 1.0 & 39 & 0.0037 & 17.91 \\
\hline Feature & $\begin{array}{c}\text { Total recharge } \\
\text { rate }^{14} \\
{\left[\mathrm{~m}^{3} / \mathrm{d}\right]}\end{array}$ & $\begin{array}{r}\text { Spe } \\
\text { rech } \\
\text { ra } \\
{[\mathbf{f t} / \mathbf{y}]}\end{array}$ & $\begin{array}{l}\text { ecific } \\
\text { large } \\
\text { ate } \\
\text { lacre] }\end{array}$ & & $\begin{array}{r}\text { Area o } \\
\text { pplicat } \\
\text { [acres }\end{array}$ & & $\begin{array}{l}\text { Area of } \\
\text { pplication } \\
{\left[\mathbf{k m}^{2}\right]}\end{array}$ \\
\hline $\begin{array}{l}\text { Imperial Valley } \\
\text { Irrigation Area }\end{array}$ & 0 - 844,853 & & $0-0.48$ & & & 25,000 & 2,125 \\
\hline $\begin{array}{l}\text { Mexico } \\
\text { Irrigation Area }^{16,17}\end{array}$ & $0-\mathbf{5 9 6 , 4 3 7}$ & & $0-0.48$ & & $\sim 36$ & 67,692 & $\sim 1,488$ \\
\hline $\begin{array}{l}\text { Annual } \\
\text { Precipitation }^{18}\end{array}$ & 14,359 & & $6 \times 10^{-3}$ & & 2,3 & 76,660 & 9,618 \\
\hline $\begin{array}{l}{ }^{1} \text { Conductivity }=\text { (rate } \times \text { be } \\
{ }^{2} \text { Conductance }=\text { conductiv } \\
{ }^{3} \text { AAC Recharge based on } \\
{ }^{4} \text { AAC Average width }=1 \\
{ }^{5} \text { AAC Average depth }=7 \\
{ }^{6} \mathrm{NR} \text { Recharge based on } 7 \\
{ }^{7} \mathrm{NR} \text { Average width }=135 \\
{ }^{8} \mathrm{NR} \text { Average depth }=8-1 \\
{ }_{9}^{9} \mathrm{CC}-\mathrm{L} \text { Recharge shown in } \\
\text { phreatophyte wetlands (e. } \\
{ }^{10} \mathrm{CC}-\mathrm{L} \text { Average width }= \\
{ }^{11} \mathrm{CC}-\mathrm{L} \text { Average depth }= \\
{ }^{12} \mathrm{CC}-\mathrm{U} \text { Average width }= \\
{ }^{13} \mathrm{CC}-\mathrm{U} \text { Average depth }= \\
{ }^{14} \text { Range in values corresp } \\
{ }^{15} \text { Recharge based upon ma } \\
{ }^{16} \text { Recharge based upon ma } \\
\text { Valley. Application } \\
{ }^{17} \text { Area of cropland in Mex }\end{array}$ & $\begin{array}{l}\text { thickness) /(cells } \times \\
\text { ity } \times \text { length } \times \text { width } / \\
94,206 \mathrm{AF} / \mathrm{y} \text { (Table } \\
50-200 \mathrm{ft}(\mathrm{IID}, 2007) \\
\text { to } 20 \mathrm{ft} \text { (IID, 2007) } \\
000 \mathrm{AF} / \mathrm{y} \text { (Montgom } \\
\mathrm{ft}(\mathrm{DOE} \text { and DOI BI } \\
5 \mathrm{ft} \text { (DOE and DOI B } \\
\text { Table } 2.2(26,000 \mathrm{~A} \\
\mathrm{g} ., \text { Reclamation, 1993 } \\
61 \mathrm{ft}(\mathrm{USBR}, 2007) \\
1 \mathrm{ft}(\mathrm{USBR}, 2007) \\
61 \mathrm{ft}(\mathrm{USBR}, 2007) \\
1 \mathrm{ft} \text { (USBR, 2007) } \\
\text { nds to range in recha } \\
\text { iximum value of 250, } \\
\text { ximum recharge rate } \\
\text { ico approximate }\end{array}$ & $\begin{array}{l}\text { nery Wats } \\
\text { BLM, } 2004 \\
\text { BLM, } 2004 \\
\text { AF/y) igno } \\
3 \text { ) }\end{array}$ & $\begin{array}{l}\text { on, 1996) } \\
\text { 4) } \\
\text { red and as }\end{array}$ & $\begin{array}{l}.4,2.5 \\
\text { acre) a } \\
\text { d a min }\end{array}$ & $\begin{array}{l}\text { and a min } \\
\text { nimum of }\end{array}$ & $\begin{array}{l}\text { iimum of } 0 \mathrm{AF} / \mathrm{y}, \mathrm{T} \\
\mathrm{f} 0 \mathrm{AF} / \mathrm{y} \text {, parallelin }\end{array}$ & $\begin{array}{l}\text { Table } 2.5 \\
\text { ing Imperial }\end{array}$ \\
\hline
\end{tabular}




\subsubsection{Groundwater Withdrawals}

Annual extraction rates or integrated discharge rates for wells lying in the groundwater basins of the model are tabulated in Table 7.3. These were determined from aggregated information in DWR (2003) and from data collected in the Salton Sea Water Resources Database. In general, groundwater withdrawals from the model domain are not significant in the basin, at least on the US side of the border. The relatively large, aggregate extraction rate of 750,000 AF/y for the entire Mexicali Valley was cited by Reclamation (2004). For the purposes of this initial model, the extraction rates are specified as an areal withdrawal in each groundwater basin, evenly through specified upper saturated portions of the model domain.

Table 7.3: Model basin groundwater pumping rates

\begin{tabular}{|c|c|c|c|c|}
\hline Groundwater Basin & $\begin{array}{c}\text { Basin } \\
\text { Area } \\
{\left[\mathbf{k m}^{2}\right]}\end{array}$ & $\begin{array}{c}\text { Portion within } \\
\text { model domain } \\
{\left[\mathbf{k m}^{2}\right]}\end{array}$ & $\begin{array}{c}\text { Annual } \\
\text { Pumping Rate } \\
{[A \mathrm{AF} / \mathrm{y}]^{1}}\end{array}$ & $\underset{\left[\mathrm{m}^{3} / \mathbf{d}\right]^{2}}{\text { Pumping rate }}$ \\
\hline Amos Valley & 529 & 501 & & \\
\hline Borrego Valley $^{2}$ & 628 & 148 & 15,161 & 51,235 \\
\hline Chocolate Valley & 549 & 20 & & \\
\hline Clark-Ocotillo Valley $^{2}$ & 899 & 645 & 3 & 10 \\
\hline Coyote Wells Valley ${ }^{2}$ & 594 & 416 & 900 & 3041 \\
\hline East Salton Sea Basin ${ }^{2}$ & 806 & 667 & 6 & 20 \\
\hline West Salton Sea Basin & 430 & 292 & & \\
\hline Ogilby Valley & 556 & 499 & & \\
\hline Imperial Valley $^{2}$ & 3,879 & 3,879 & 25,600 & 86,513 \\
\hline US Total & 8,870 & 7,566 & 41,670 & 140,819 \\
\hline Mexico $^{4,5}$ & & 2,052 & 750,000 & $2,534,562$ \\
\hline Model Total & & 9,618 & 791,670 & $2,675,381$ \\
\hline
\end{tabular}

$1 \mathrm{AF} / \mathrm{y}=3.38 \mathrm{~m}^{3} / \mathrm{d}$

${ }^{2}$ Estimated from Table 2.3 (DWR, 2003)

${ }^{3}$ Estimated from discharge rates in Water Resources Database (Sections 3, 4, Figure 4.6)

${ }^{4}$ Irrigation area in Mexico estimated at $1,488 \mathrm{~km}^{2}$

${ }^{3}$ Total pumping rate in Mexicali Valley cited by Reclamation (2004)

\subsubsection{Hydraulic Conductivity and Porosity in the Shallow System}

Estimates of hydraulic conductivity and porosity in the shallow aquifer materials were derived from various reports and soil databases and were also inferred from tracer migration data of Section 6 (Table 7.4). These are described in brief below:

- A soil classification study based on geographic distribution of surface soils (Davids Engineering, 2007) estimated hydraulic conductivities between 0.13 and $0.33 \mathrm{in} / \mathrm{hr}(0.079$ to $0.20 \mathrm{~m} / \mathrm{d})$ for fine-grained soils in the area from and between 11.4 and $12.29 \mathrm{in} / \mathrm{hr}(6.6$ 
to $7.5 \mathrm{~m} / \mathrm{d}$ ) for coarse-grained soils. An area-weighted geometric mean of these conductivities yields a conductivity range of 0.14 to $7.28 \mathrm{~m} / \mathrm{d}$ (Table 7.4 )

- The class-average hydraulic conductivity determined from the USDA soil textural classes (USDA, 2007) indicate hydraulic conductivities in the range of 0.08 to $0.14 \mathrm{~m} / \mathrm{d}$ for fine grained clay and clay loam soils, respectively, and in the range of 1.1 to $4.6 \mathrm{~m} / \mathrm{d}$ for coarse grained loamy sand and sandy soils, respectively.

- In a previous modeling effort, Tetra Tech (1999) cited hydraulic conductivity values ranging from 36 to $428 \mathrm{ft} / \mathrm{d}$ ( 11 to $130.5 \mathrm{~m} / \mathrm{d}$ ), with lower values related to fine lake bed sediments to the northwest and larger values related to coarser sand and gravel deposits to the southeast.

- A USGS groundwater flow and transport model of the Upper Coachella Valley, based upon previous modeling studies by Tyley (1974) and Swain (1978), cited estimates of hydraulic conductivity in the range of $1.1 \times 10^{-4}$ to $9.0 \times 10^{-4} \mathrm{ft} / \mathrm{s}(7.9$ to $23.7 \mathrm{~m} / \mathrm{d})$ in the southern portions of the Coachella Valley that border the northern portion of the current model domain.

- The results of the isotopic tracer analysis in the East Mesa (Section 6) were used to infer hydraulic conductivity $(\mathrm{K})$ from estimates of the local hydraulic gradient $(\mathrm{J})$, porosity $(\phi)$, and travel time (groundwater age, T) along an inferred flow line connecting the All American Canal and an isotopic sampling point some distance (L) away (e.g., as in Figure 6.10). The inference was based upon the application of Darcy's law

$$
\frac{L}{T} \sim v=-\phi K J
$$

and yielded an average hydraulic conductivity of $105.1 \mathrm{~m} / \mathrm{d}$ for the coarse grained soils in this area. This approach assumes a linear gradient between the water surface at the All American Canal and the corresponding observation well and it does not account for water mounding, localized pumping and well losses.

- A mean porosity of 0.35 will be applied to the upper layers (1-9) which is consistent with the lower bound of mean porosities $(0.42 \pm 0.07)$ of the clay, clay loam, loamy sand and sand textural classes (USDA, 2007).

In the model, two effective, isotropic hydraulic conductivity values were used to characterize the fine- and coarse-grained materials in the shallow system. These values, 0.17 and $30.68 \mathrm{~m} / \mathrm{d}$, were determined from geometric means of the low and coarse-grained values cited above and indicated in Table 7.4.

\subsubsection{Hydraulic Conductivity and Porosity in the Deeper System}

Hydraulic conductivities for the primary geologic units used in the model were computed from permeability and temperature profiles adapted from Riney et al. (1982). Dynamic viscosity and density of water was adjusted to account for the variable temperature changes with depth (Table 7.6). 
Porosity estimates of the lower Palm Spring - Borrego and Imperial formations were derived from formation porosities based on observed and interpolated data from 14 deep geothermal wells (Riney et al., 1982). In general, it was observed that porosity decreases with depth. Permeability generally increases to a depth near $2500 \mathrm{ft}$ due to an increase in sandstone abundance, but generally decreases at lower depths due to an increase in shale content (Table 7.5). Dutcher et al. (1972) computed porosity for the upper 1400 foot of the formation using formation density logs and neutron porosity logs. For deeper depths (8000 feet below land surface), porosities from a sonic log were corrected for hole diameter and formation compaction and subsequently adjusted to better correlate data from a shallower well. In general, porosity decreases with depth (Figure 7.5).

Table 7.4: Physical properties of upper model layers (layers 1-9). Shaded areas represent fine-grained materials.

\begin{tabular}{|c|c|c|c|c|c|}
\hline Source & Name/ Class / Location & Porosity $\phi$ & $\begin{array}{c}K_{\text {sat }} \\
{[\mathbf{m} / \mathbf{d}]}\end{array}$ & $\log K_{\text {sat }}$ & $\begin{array}{c}\text { Average } K \\
{[\mathbf{m} / \mathbf{d}]^{1}}\end{array}$ \\
\hline \multirow{14}{*}{$\begin{array}{l}\text { Davids } \\
\text { Engineering, } \\
2007\end{array}$} & Imperial silty clay & & 0.079 & -1.101 & \multirow{9}{*}{$0.14^{2}$} \\
\hline & Imperial silty clay, saline & & 0.079 & -1.101 & \\
\hline & Imperial silty clay, wet & & 0.085 & -1.069 & \\
\hline & Holtville silty clay & & 0.104 & -0.985 & \\
\hline & Holtville silty clay, wet & & 0.104 & -0.985 & \\
\hline & $\begin{array}{l}\text { Meloland very fine sandy } \\
\text { loam, wet }\end{array}$ & & 0.122 & -0.914 & \\
\hline & $\begin{array}{l}\text { Holtville-Imperial silty clay } \\
\text { loams }\end{array}$ & & 0.146 & -0.835 & \\
\hline & $\begin{array}{l}\text { Imperial-Glenbar silty clay } \\
\text { loams, } 2 \text { to } 5 \text { percent slopes }\end{array}$ & & 0.201 & -0.696 & \\
\hline & $\begin{array}{l}\text { Imperial-Glenbar silty clay } \\
\text { loams, wet, } 0 \text { to } 2 \text { percent } \\
\text { slopes }\end{array}$ & & 0.201 & -0.696 & \\
\hline & $\begin{array}{l}\text { Rositas fine sand, } 2 \text { to } 9 \\
\text { percent slopes }\end{array}$ & & 6.949 & 0.842 & \multirow{5}{*}{$7.28^{2}$} \\
\hline & $\begin{array}{l}\text { Rositas fine sand, } 0 \text { to } 2 \\
\text { percent slopes }\end{array}$ & & 7.205 & 0.858 & \\
\hline & $\begin{array}{l}\text { Carsitas gravelly sand, } 0 \text { to } \\
5 \text { percent slopes }\end{array}$ & & 7.248 & 0.860 & \\
\hline & $\begin{array}{l}\text { Rositas fine sand, wet, } 0 \text { to } \\
2 \text { percent slopes }\end{array}$ & & 7.291 & 0.863 & \\
\hline & $\begin{array}{l}\text { Rositas sand, } 0 \text { to } 2 \text { percent } \\
\text { slopes }\end{array}$ & & 7.492 & 0.875 & \\
\hline
\end{tabular}




\begin{tabular}{|c|c|c|c|c|c|}
\hline \multirow{4}{*}{$\begin{array}{c}\text { USDA, } \\
2007\end{array}$} & Clay & $0.42 \pm 0.07$ & 0.148 & -0.831 & \multirow{2}{*}{0.1} \\
\hline & Clay loam & $0.42 \pm 0.07$ & 0.082 & -1.087 & \\
\hline & Loamy Sand & $0.42 \pm 0.07$ & 1.052 & 0.022 & \multirow{2}{*}{2.6} \\
\hline & Sand & $0.42 \pm 0.07$ & 6.427 & 0.808 & \\
\hline \multirow{2}{*}{$\begin{array}{c}\text { Tetra Tech, } \\
1992\end{array}$} & Low & & & 1.040 & 11.0 \\
\hline & High & & & 2.115 & 130.5 \\
\hline \multirow{2}{*}{$\begin{array}{c}\text { Tyley } \\
(1972), \\
\text { Swain } \\
(1978)\end{array}$} & High & & 7.900 & 0.898 & \multirow[b]{2}{*}{13.7} \\
\hline & High & & 23.700 & 1.375 & \\
\hline \multirow{6}{*}{$\begin{array}{l}\text { Isotopic } \\
\text { Tracer } \\
\text { Study }^{3}\end{array}$} & Well 105116 & & 113.5 & 2.055 & \multirow{6}{*}{105.1} \\
\hline & Well 105117 & & 19.0 & 1.279 & \\
\hline & Well 105118 & & 32.9 & 1.518 & \\
\hline & Well 105121 & & 188.9 & 2.276 & \\
\hline & Well 105124 & & 557.8 & 2.747 & \\
\hline & Well 105125 & & 180.5 & 2.257 & \\
\hline \multirow{2}{*}{ This Model } & Fine & 0.35 & & & 0.17 \\
\hline & Coarse & 0.35 & & & 30.68 \\
\hline
\end{tabular}

${ }^{\mathrm{I}}$ Geometric mean

${ }^{2}$ Area weighted, geometric mean

${ }^{3}$ Section 6; Applies only to coarse textured soils 


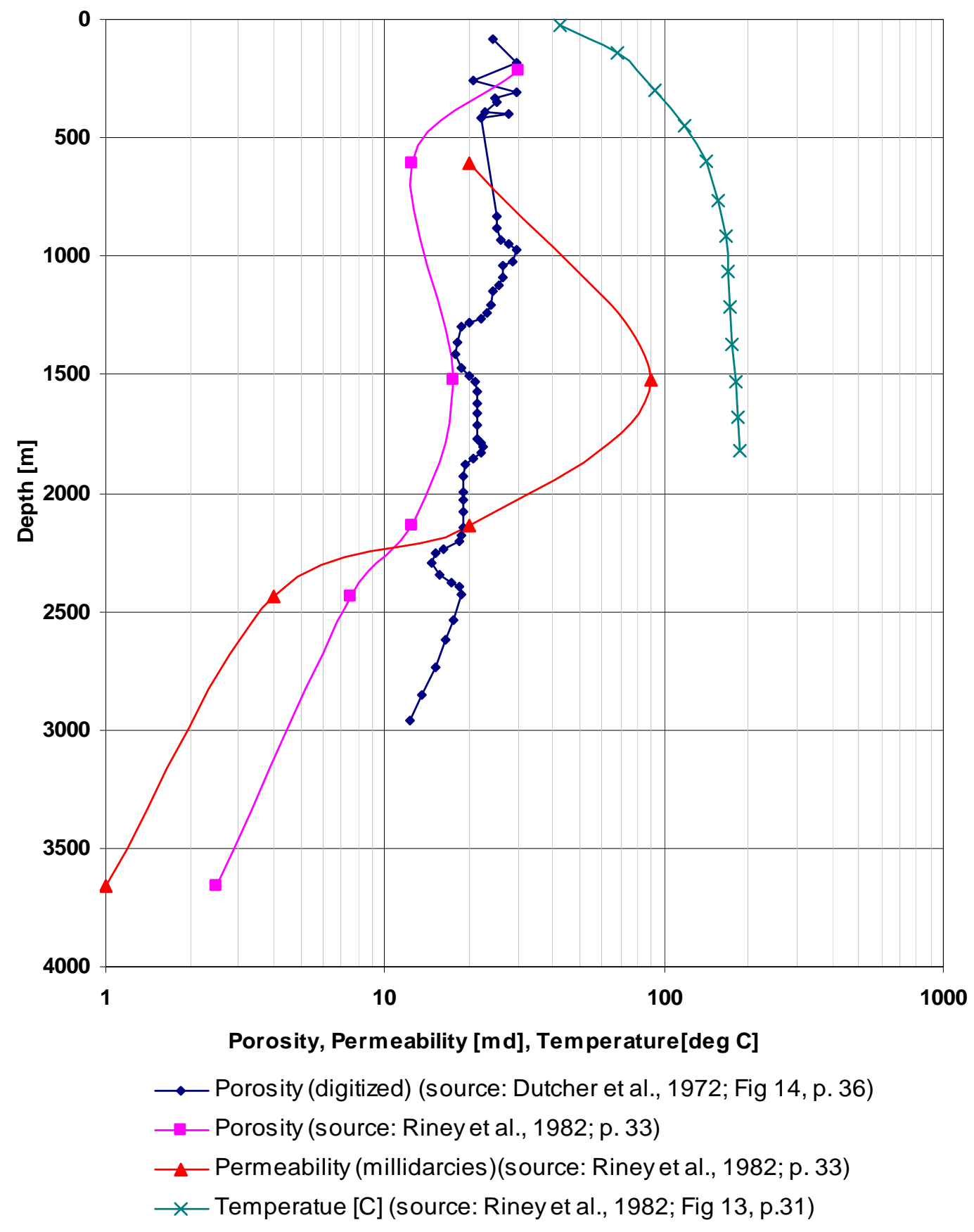

Figure 7.7: Depth dependant porosity, permeability and temperature 
Table 7.5: Physical property of lower model layers (layers 10,11)

\begin{tabular}{|c|c|c|c|c|c|c|c|}
\hline $\begin{array}{c}\text { Depth } \\
{[\mathbf{m}]^{1}}\end{array}$ & $\begin{array}{c}\text { Thickness } \\
{[\mathrm{m}]}\end{array}$ & $\begin{array}{c}\text { Geologic } \\
\text { Unit }\end{array}$ & Description & $\underset{(\mathbf{m d})^{2}}{\mathbf{k}}$ & $\begin{array}{l}\text { Temp } \\
\left.{ }^{\circ} \mathbf{C}\right]^{3}\end{array}$ & $\underset{[\mathbf{m} / \mathbf{d}]^{4}}{\mathbf{K}}$ & Porosity \\
\hline 610 & 610 & $\begin{array}{l}\text { Palm Spring - } \\
\text { Borrego }\end{array}$ & $\begin{array}{l}\text { Sand content, } \\
\text { good shale } \\
\text { porosity }\end{array}$ & 20 & 75 & 0.74 & 13 \\
\hline 1524 & 914 & $\begin{array}{l}\text { Palm Spring - } \\
\text { Borrego }\end{array}$ & $\begin{array}{l}\text { Gradual } \\
\text { decrease } \\
\text { percentage of } \\
\text { sandstone }\end{array}$ & 90 & 121 & 5.14 & 18 \\
\hline 2134 & 1219 & $\begin{array}{l}\text { Palm Spring - } \\
\text { Borrego }\end{array}$ & $\begin{array}{l}\text { Gradual } \\
\text { decrease } \\
\text { percentage of } \\
\text { sandstone }\end{array}$ & 20 & 147 & 1.36 & 13 \\
\hline 2438 & 1219 & $\begin{array}{l}\text { Palm Spring - } \\
\text { Borrego }\end{array}$ & $\begin{array}{l}\text { Abrupt } \\
\text { decrease in } \\
\text { percentage of } \\
\text { sandstone }\end{array}$ & 4 & 156 & 0.29 & 8 \\
\hline \multicolumn{2}{|c|}{$\begin{array}{c}\text { Depth-Weighted } \\
\text { Average }\end{array}$} & $\begin{array}{l}\text { Palm Spring - } \\
\text { Borrego }\end{array}$ & & & & $1.04^{6}$ & 12 \\
\hline 3658 & 2438 & Imperial & $\begin{array}{l}\text { Shale-rich } \\
\text { sequence }\end{array}$ & 1 & 170 & 0.077 & 2.5 \\
\hline
\end{tabular}

${ }^{1}$ Adapted from Riney et al. (1982), Table 2, p.33

${ }^{2} \mathrm{k}=$ permeability [millidarcies, $\mathrm{md}$ ]

${ }^{3}$ Interpolated from Riney et al. (1982), Fig. 13, p21 (Temperature profile for Mesa 6-2 well). See Figure 3.

${ }^{4} \mathrm{~K}=$ Hydraulic conductivity $=\mathrm{k \rho g} / \mu\left(\mathrm{k}=\right.$ permeability $\left[\mathrm{m}^{2}\right], \rho=$ temperature adjusted density $\left[\mathrm{kg} / \mathrm{m}^{3}\right], \mathrm{g}=$ acceleration due to gravity $\left(9.81 \mathrm{~m} / \mathrm{s}^{2}\right), \mu=$ temperature adjusted dynamic viscosity $\left[\mathrm{N} \mathrm{s} / \mathrm{m}^{2}\right]$

${ }_{6}^{5}$ Average layer values from Riney et al. (1982), Table 2, p.33

${ }^{6}$ Depth weighted hydraulic conductivity based on log-transformed values

\subsection{A Preliminary Model Result and Discussion}

A series of preliminary, uncalibrated steady-state model simulations were made, based upon the boundary condition, recharge, and parameter specifications made earlier in this section. An output of the groundwater elevation (or head) in layers 1 and 3 are presented in Figures 7.7ac. In general, groundwater flows from the Colorado River towards the Salton Sea in a northwesterly direction, with calculated groundwater elevations ranging from 17.4 to $-70.5 \mathrm{~m}$.

The model dries out along the eastern and western edges of the upper layers. In the east, this primarily reflects a lack of recharge, while in the West, the upper layer is still fairly dry owing to higher terrain. Notably, mountain front recharge from the western basin perimeter ranges, primarily from the Santa Rosa and Vallecito mountains, has a noticeable affect on the 
overall groundwater flow solution (Section 7.1.5). This suggests areas for evaluating additional, sustainable production scenarios in a more complete calibrated model.

Recharge from the AAC in the East Mesa is also evident, as are the effects of the relatively high production rates in Mexico.

Flooding of cells occurs along the lower reaches of the Alamo and New rivers indicating discharge of water into the rivers and into the densely irrigated lands in these areas. Flooded water, in actuality, would not pond as indicated, but, rather, would be captured and routed into the Salton Sea by the extensive drainage network in this area (which is not included in the model). In a gross sense, this is consistent with perceived artesian conditions in this area, but this behavior would be better evaluated after additional model calibration and refinement activities are concluded (see below).

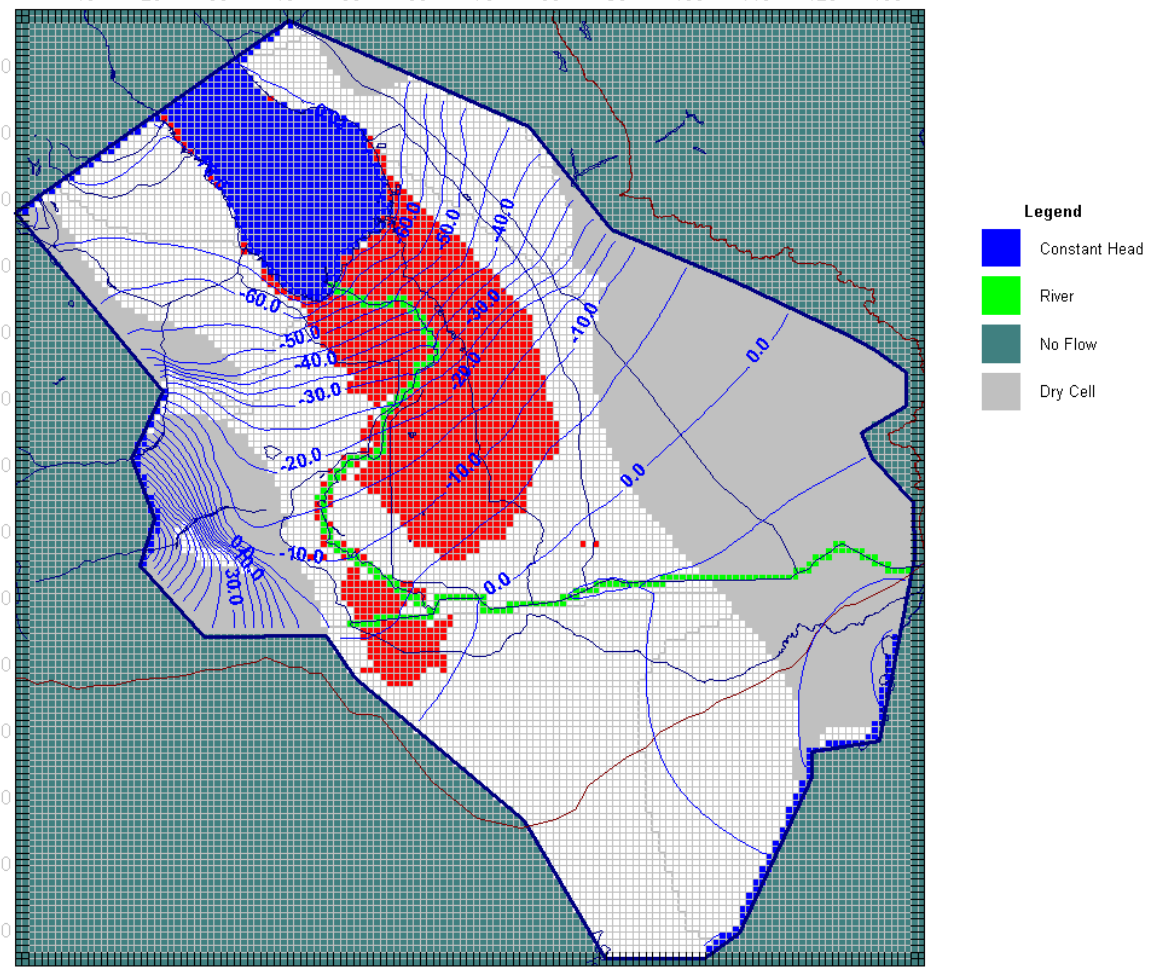

Figure 7.8a: Simulated groundwater elevation in Layer 1 


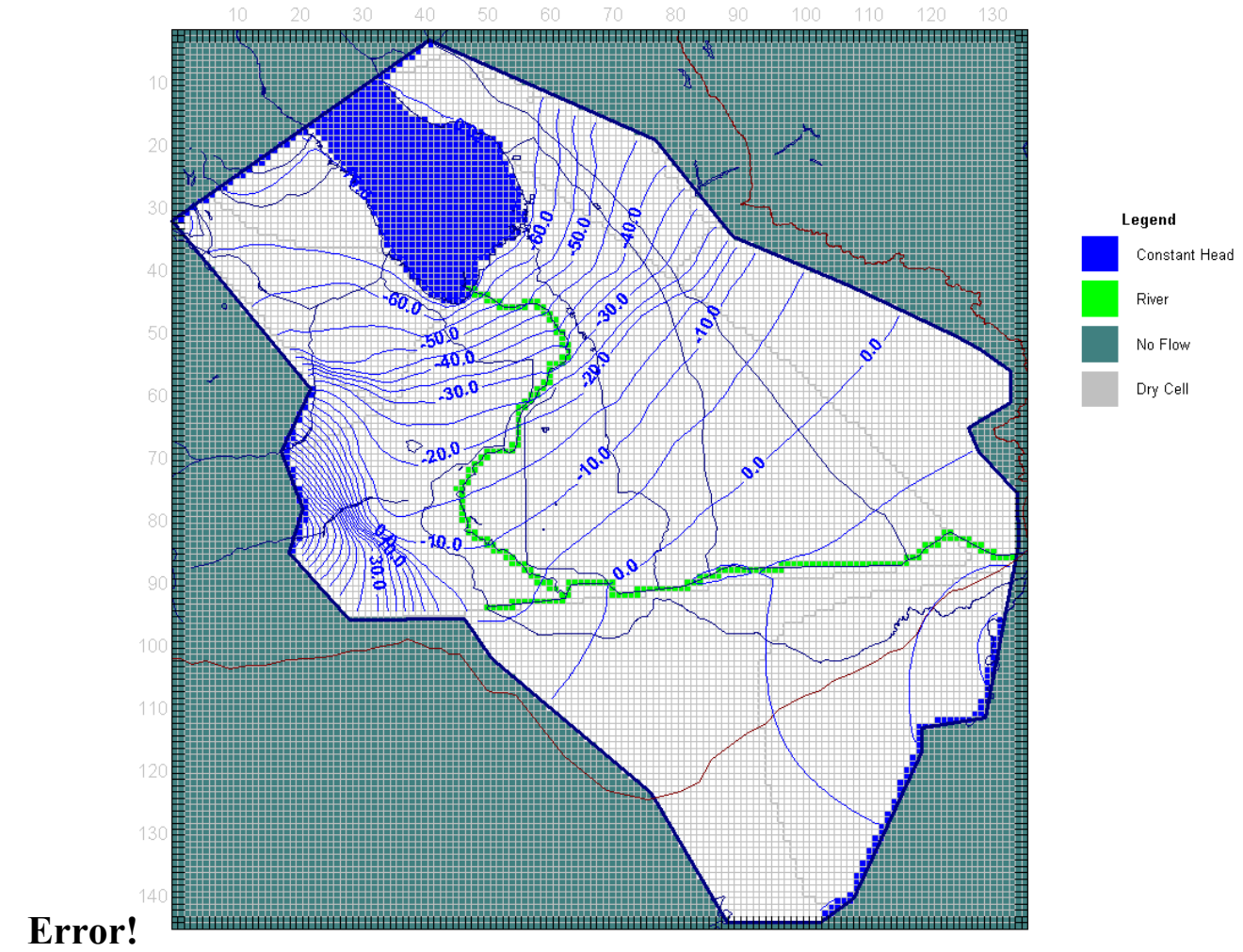

Figure 7.8b: Simulated groundwater elevation in Layer 1 (dry and flooded cells omitted)

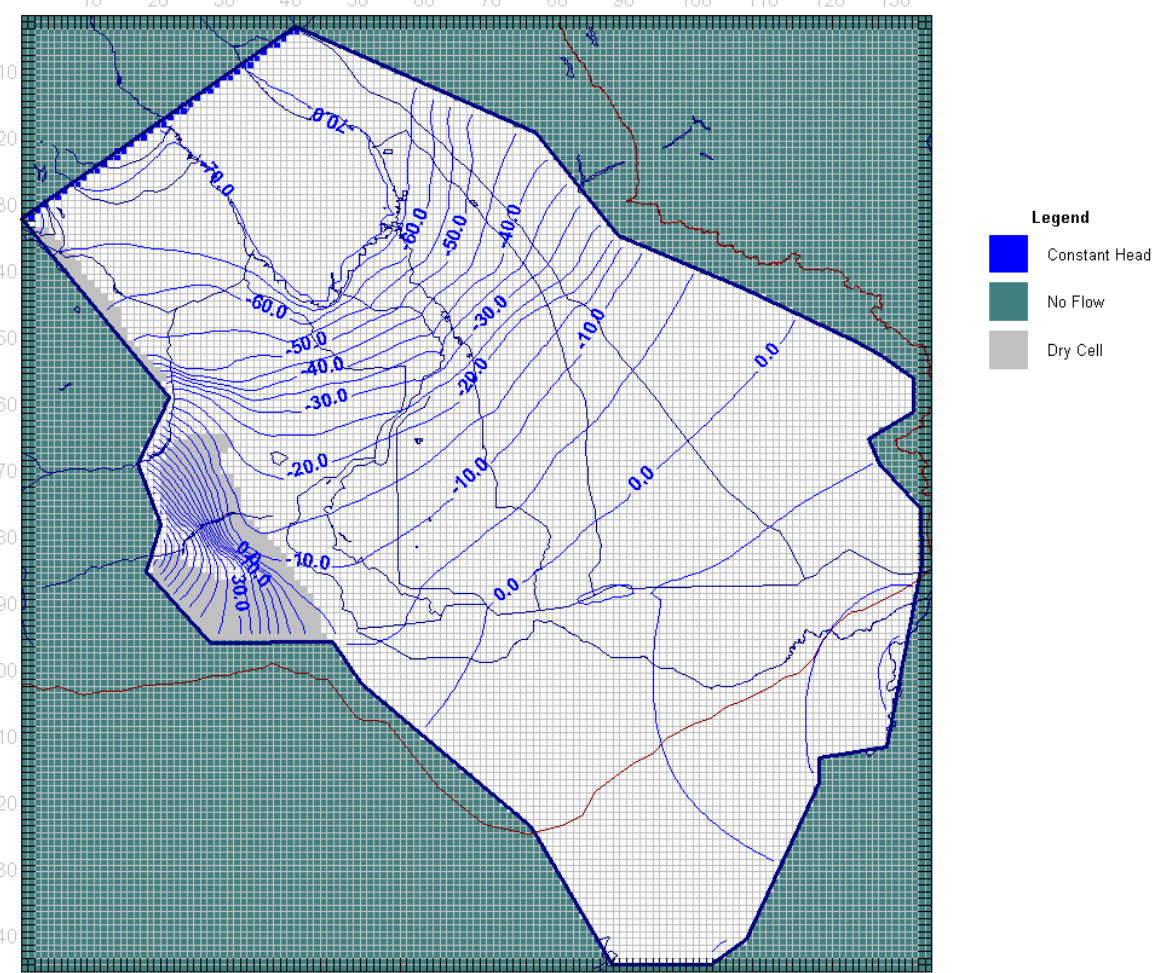

Figure 7.8c: Simulated groundwater elevation in Layer 2 98

Ground Water Availability within the Salton Sea Basin: A Final Report Lawrence Livermore National Laboratory 


\subsection{Working Towards a Calibrated and Tested Model}

This portion of the study was not intended to develop a fully calibrated, tested, or complete numerical model. It does, however, develop a preliminary conceptual framework for a steady-state model that can be further developed, refined, and evaluated within a broader calibration framework. Additional steps that should, or could be taken in this process include:

- Refinement of boundary conditions used along the bottom and side edges of the domain, particularly in areas where recharge or underflow conditions may be present, and in the model areas in Mexico. Sensitivity or uncertainty studies will eventually be useful in this process.

- Improved specification of well production activities, both in the US and in Mexico, using individual wells when able instead of areal-averaged withdrawal rates. Sensitivity or uncertainty studies will be useful in this process.

- Improved specification of aquifer recharge rates from irrigation losses, canal leakage, and precipitation, and evapotranspiration processes. This will especially be relevant near the mountain front ranges that surround the western perimeter of the model where runoff may augment and contribute heavily to the precipitation-based fraction of recharge.

- Development and implementation of calibration strategies to better estimate hydrologic parameters (e.g., hydraulic conductivity), define or refine the geometry of important geologic hydrofacies, and examine important sensitivities and uncertainties associated with these specifications. Use of calibration and parameter estimation software such as PEST (Doherty, 2000) or UCODE (Poeter and Hill 1998) in this process is highly recommended.

- Improved grid design, including use of greater resolution in important areas such as the canal areas or East Mesa; addition of refined drainage networks and channel elements into the model, and/or use of transient analyses to examine seasonal or shorter-term variations in groundwater flow and recharge behavior.

- Further analyses of groundwater quality, age, and source or travel time indicators (e.g., Figure 6.10), their reconciliation with corresponding model predictions of groundwater quality, age, and source, and their role, influence, and connection to water quality in the Salton Sea proper.

- Initiation of planning studies that address sustainable water production opportunities in the West Mesa and San Felipe Creek watershed areas and potential future aquifer storage and recovery alternatives in the East Mesa.

- Recommendations for obtaining additional characterization data (e.g., from a new production or monitoring wells, as discussed in Section 6.4 and Figure 6.10) and ongoing incorporation of new data and information for the continual improvement of the model.

- Development of additional analyses and calibration studies of the deeper hydrologic system and its interactions with, or affect upon, the shallower aquifer system. This effort may require use of additional groundwater models that can address energy balances in 
thermally-driven and concentration-dependent flow systems (e.g., Pruess, 1991; Nitao, 1995; WASY, 2007). 



\section{Section 8: \\ Summary, Conclusions and Recommendations}

\subsection{Summary}

The subject of this report is the development of an integrated groundwater availability assessment for the Salton Sea Basin. Renewed interest in groundwater as an additional water supply, especially in the Imperial Valley, has been motivated by

- Increasing demands for Colorado River water from urban centers outside of the Basin (e.g., San Diego);

- Reduced Colorado River allocations for California, including the Imperial Valley, resulting from a recent Federal and Sate agency agreements; and

- Potential new needs for water to support various Salton Sea restoration alternatives focused on salinity reduction and/or/broader ecological preservation efforts.

In the current context, groundwater availability is defined by volume and capacity of the basin (e.g., storage), producibility of groundwater, quality of groundwater, and the overall potential for sustained renewability of groundwater.

As a whole, groundwater storage in the basin is very large, potentially as high as 4.5 to 6.5 billion acre-feet (AF) in current estimates, yet much of this is confined to greater depths where quality is poor (high salinity), producibility is low (poor permeability and accessibility) and natural recharge, required for sustained use as a supply, is not well demonstrated from available data.

Historically producible groundwater in the basin has been confined to a "shallow" system, extending to no more than $2,000 \mathrm{ft}$ deep in most areas, and which is typically considered to be isolated from a "deeper" system that can extend to as much as $20,000 \mathrm{ft}$ in depth. Producibility conditions in the shallower system can vary from very good to very poor. In the central Imperial Valley, for example, poor producibility is often associated with low permeability sediments associated with Colorado River delta deposits, while larger permeabilities can be found in many perimeter areas of the valley, as well as in the Coachella Valley to the north where these lower permeability materials are less prevalent. Similarly, groundwater quality conditions in the shallow system can also vary widely across the basin, and often show high salinities derived from mineralogic or ancient seawater sources, agricultural return flows, or other wastewaters.

Groundwater renewability in the shallow system, as realized through groundwater recharge, is dominated in the southern portion of the basin by Colorado River water derived from irrigation returns in the agricultural areas, localized canal leakage along the All American and Coachella Canals, or from the River itself along the southern basin boundary in Mexico. Precipitation-based recharge is very low over much of the basin. It is highest in the western and 
northwestern perimeter mountain front areas, especially in the Coachella Valley where production from artesian wells, derived from natural recharge, is significant. Artificial aquifer storage and recovery (ASR) projects are also used as a means of recharge, again, primarily, in the Coachella Valley.

In many areas of the Imperial Valley, groundwater in storage has been decreasing as a result of increased domestic production, suggesting that the newer production may not be offset by existing recharge. In some West Mesa areas, this is not yet the case, but total production should, to the first order, not to exceed potential (natural) recharge, which has been estimated to be quite small.

In order to advance the development of this groundwater availability assessment, the work in this project focused on two principal activities. In Phase I, and in coordination with Reclamation staff, we established and implemented a baseline process to acquire, assemble, organize, and make accessible as much of the existing and relevant hard data and interpretive information as possible that relate to quantifying groundwater availability in the Salton Sea area. This effort was viewed as an essential integrative process that compiles as much available information as possible from all potential sources, in one place, and in a manner that will allow for continuous expansion and updating within a defined data structure and format over time. This phase was seen as a process that would enable the acquisition and more effective interpretation of data for assessment purposes. Specifically, Phase I activities included

- Designing and implementing two electronic, web-based hierarchical databases - one for all pertinent Hard Data, and the other for all related Interpretive Information literature;

- Designing and implementing a related Geographic Information System (GIS), dynamically linked to these databases; and

- Acquisition, review, assembly, and organization of as much of the available Hard Data and Interpretive Information as possible into these databases, allowing for continual updating as necessary

In Phase II, the results of Phase I were reviewed and considered, again in coordination with Reclamation staff, as a basis to develop new information related to groundwater source, age, and quality in the East Mesa and as a means to better characterize flow and recharge pathways in the region. Specifically, we

- Developed and implemented a groundwater isotope sampling study in the East Mesa as a means to detect and determine historical recharge patterns and flow rates

In addition, Phase II work also included

- Initial development of a more integrated conceptual flow model for the basin as a whole, as a means for groundwater flow model development;

- Initialized the development of a regional groundwater flow model in the Imperial and Mexicali Valleys as a means to assess the potential for groundwater banking opportunities and the viability of new production in the West Mesa areas 


\subsection{Findings and Conclusions}

Within the US side of the basin, any significant additional groundwater production would have to be sustainable in the sense that it is balanced by existing or potential new sources of recharge. In the Coachella Valley, increased production in the shallow system has been made possible through ASR projects that yield close to 220,000 AF/year in additional recharge and production capacity. In the Imperial Valley, increased production opportunities in the shallow system are limited to (i) potential portions of the West Mesa area fed by mountain front runoff, and (ii) opportunities to utilize excess Colorado River water to support an ASR project in the East Mesa, mimicking or continuing, in a sense, the canal leakage processes that have been occurring since the 1940s. Increased production opportunities in the deeper system may be possible, but may be hampered by the producibility, quality, and renewability concerns mentioned above, as well as other impacts such as subsidence.

With regard to (i), precipitation-based recharge rates in the western perimeter groundwater basins are not large yet they are among the highest in the Imperial Valley as a whole. Many of these basins include a number of highly productive wells, yet have, in general, stable to declining water level trends that can be correlated to steady increases in local production over the past half century. Notably, the Vallecito-Carrizo basin has been showing rising levels of groundwater of 10 to 20 feet over the same period. It has an estimated storage capacity of 2.5 MAF yet a recharge rate of only $2,000 \mathrm{AF} / \mathbf{y}$. As discussed in Appendix A, the estimated recharge rate would be much higher if runoff from the western mountain fronts were taken into account in the estimation process, but would certainly be bounded by the local $\sim \mathbf{6 0 , 0 0 0} \mathrm{AF} / \mathbf{y}$ precipitation rate that contributes to runoff and recharge in the immediate basin area. This suggests that increased rates of renewable groundwater production in this basin may not be sustainable at large levels even though the cited recharge rate may underestimate the actual value. Application of better rainfall-runoff models in the greater West Mesa and upper watershed areas, for example, will lead to more accurate recharge estimates. Additionally, application of calibrated groundwater models in the Vallecito-Carrizo basin will be effective in planning and optimizing any new water extraction scenarios in the future.

With regard to (ii), one promising approach for development of new groundwater resources in the Imperial Valley would be to develop an ASR-like project in the East Mesa and to assess its viability through renewed analyses of the $60+$ years of canal leakage that has been occurring from the Coachella and All American Canals. For the AAC specifically, aggregate losses between 1948 and 1988 totaled 4.9 MAF (or 123,000 AF/y on average), yet estimates of accrued increases groundwater in storage under the canal lay only between $\mathbf{7 0 0 , 0 0 0} \mathbf{A F}$ and 1.5 MAF. Quantification of this difference and the mechanisms that contribute to it (e.g., steady losses to evapotranspiration, discharges into agricultural drains and canals, etc.) will be critical to the efficacy and design criteria for any ASR project in this particular area. Isotopic analyses of groundwater in the area have proven useful in the identification of the source and ages of water in and around the existing mound, but clearly need to be augmented with additional sampling locations. Application of calibrated groundwater models in the East Mesa have been and will continue to be effective tools in this design and assessment process. 


\subsection{Additional Recommendations}

Based upon the conclusions above the following recommendations are provided to assist in developing further actions in terms of quantifying groundwater availability in the basin:

\subsubsection{Continued Groundwater Model Development}

Continuation of the development, calibration, and application of the regional groundwater flow model would provide a means to both (i) design and evaluate the efficacy of ASR schemes in the East Mesa area and (ii) evaluate possibilities and limits of increased groundwater production in the West Mesa area. In some sense, this may involve shorter and longer-term efforts as new data and interpretations are folded into the overall modeling endeavor, as described in the next sections below.

\subsubsection{Additional Isotopic Sampling in the East Mesa}

We recommend additional isotopic sampling and interpretation studies in the East Mesa area through the installation of several strategically located multilevel monitoring wells. This suggestion is motivated, in part, by the lack of existing wells in the area that limited our ability to sample groundwater with a sufficient spatial density. Additional data will provide a better means to (i) further quantify historical groundwater flow and storage behavior in the East Mesa area arising from canal leakage, and (ii) calibrate the regional groundwater flow model in this area.

\subsubsection{Precipitation, Runoff, and Evapotranspiration Along the Western Basin}

A more advanced evaluation of precipitation, runoff, and evapotranspiration processes along the mountain front regions along the western perimeter of the basin would provide a means to (i) better quantify the shallow groundwater recharge in the West Mesa and nearby areas that may then allow us to (ii) define a more reliable upper-bound estimate of the sustainable "safe" groundwater yield in these areas. Current precipitation and recharge estimates, as reviewed in Appendix A, do not sufficiently account for runoff from the higher terrain areas, which may substantially alter the recharge scenarios presented. Nevertheless, the raw precipitation in these areas, if considered to be completely routed to the principal aquifer sub basin(s), will certainly provide a high upper bound for the yields.

\subsubsection{Further Evaluation of the Deeper Aquifer Flow System}

This suggestion, although perhaps not as directly relevant as the first three, proposes the use of the groundwater model, or a similar model capable of accounting for thermally and density dependent flows, to evaluate groundwater flows between the deeper and shallow aquifer systems. This may provide a means to (i) evaluate to what extent the deeper system is recharged by waters derived from the upper system and (ii) whether any sustainable water development could be pursued in the deeper system as a result. 


\section{Cited References}

Aeschbach-Hertig, W., Peeters, F., Beyerle, U., and Kipfer, R. (1999) Interpretation of dissolved atmospheric noble gases in natural waters, Water Resources Research, 35, 2779-2792.

Allen, R. G., L. S. Pereira, D. Raes, and M. Smith (1998), Crop evapotranspiration - Guidelines for computing crop water requirements, FAO Irrigation and drainage paper 56, FAO - Food and Agriculture Organization of the United Nations, Rome (http://www.fao.org/docrep/x0490e/x0490e00.htm)

Bear, J. (1979), Hydraulics of Groundwater, McGraw-Hill, New York.

Bevin, K. J. (2001), Rainfall-Runoff Modelling, John Wiley, New York.

Bloyd, R. M. Jr. (1971), Underground Storage of Imported Water in the San Gorgonio Pass Area, California, U.S. Geological Survey Water Resources Division, Water Supply Paper 1999-D, $80 \mathrm{pp}$

Brown, J. S. (1923), The Salton Sea Region, California: A Geographic, Geologic and Hydrologic Reconnaissance with a Guide to Desert Watering Places, U.S. Geological Survey Water Supply Paper 497, 292 pp

Borrego Water District (2000), Groundwater Management Study Technical Committee Workbook, $100 \mathrm{pp}$

Borrego Water District (2002), Groundwater Management Plan, 76 pp

Boyle Engineering Corporation (1988), San Gorgonio Pass Water Agency Water Resources Investigation, Groundwater Dependable Yield, Draft Report, 35 pp

Boyle Engineering Corporation (1993), Groundwater Investigation Beaumont-Banning Area, Prepared for San Gorgonio Pass Water Agency

BCVWD (1995), Water Management Situation in the San Gorgonio Pass, Beaumont-Cherry Valley Water District

Cohen, M. J., J. I. Morrison, and E. P. Glenn (1999), Haven or Hazard: The Ecology and Future of the Salton Sea Pacific Institute for Studies in, Development, Environment, and Security, Oakland, CA

Cohen, M. J. (2005), Integrated Water Management Plan Evaluation: A review of the Salton Sea Authority's Preferred Project Concept for Rehabilitating the Salton Sea, Pacific Institute for Studies in, Development, Environment, and Security, Oakland, CA

Cooperative Extension Service (1997), A simple evapotranspiration model for Hawaii: The Hargreaves Model, College of Tropical Agriculture and Human Resources (CTAHR), University of Hawaii at Manoa, CTAHR Fact Sheet - Engineer's Notebook no. 106, 2pp.

Craig, H (1961), Isotopic variations in meteoric waters, Science, 133, 1702-1703.

CVWD (2000a), Engineer's Report on Water Supply and Replenishment Assessment 2000/2001, Coachella Valley Water District, Coachella, California. 46 p.

CVWD (2000b), Coachella Valley Water Management Plan (Draft). Coachella Valley Water District, Coachella, California, 272 pp 
CVWD (2006), 2005-2006 Annual Review and Water Quality Report, Coachella Valley Water District, Coachella, California

Davids Engineering, Inc. (2007). Efficiency Conservation Definite Plan: 2.A. ON-FARM ANALYSES Overview (Volume 1). Prepared as part of the Imperial Irrigation District Efficiency Conservation Definite Plan, Technical Appendices 2A. through 2C, p.3

DGI (2007), EarthVision software, Dynamic Graphics, Inc., Alameda, CA 94501; http://www.dgi.com;

DPW (1954), Ground Water Occurrence and Quality, Colorado River Basin Region. Water Quality Investigations Report No. 4., California Department of Public Works, 59 pp

Doherty, J. (2000), PEST: Model-Independent Parameter Estimation. Watermark Numerical Computing.

Dutcher, L. C., W. F. Hardt, and W. R. Moyle, Jr., (1972): Preliminary appraisal of ground water storage with reference to geothermal resources in the Imperial Valley area, California, Geological Survey Circular 649, prepared in cooperation with the US Bureau of Reclamation, US Geological Survey, Washington, DC.

DWR (1963), Data on Water Wells and Springs in the Chuckwalla Valley Area, Riverside County, California. Bulletin 91-7, California Department of Water Resources

DWR (1964) Coachella Valley Investigation, Bulletin 108, California Department of Water Resources $145 \mathrm{pp}$

DWR (1967), Ground Water Occurrence and Quality: San Diego Region, Bulletin No. 106-2, California Department of Water Resources $106 \mathrm{p}$.

DWR (1973), Ground Water Quality Problem, Coyote Well Hydrologic Unit: November 1 and 29, 1972, California Department of Water Resources Memorandum Report for California Regional Water Quality Control Board

DWR (1975), California’s Groundwater, Bulletin No. 118, California Department of Water Resources, $135 \mathrm{pp}$

DWR (1979) Coachella Valley Area Well Standards Investigation, California Department of Water Resources, Southern District Memorandum Report, 40 pp

DWR (1984), Borrego Valley Water Management Plan, California Department of Water Resources, $45 \mathrm{pp}$

DWR (1987), Ground Water Storage, Movement, and Quality Data, California Department of Water Resources, San Gorgonio Pass Water Agency, Letter Report. September, 43 pp

DWR (1998), California Water Plan Update, Bulletin 160-98, California Department of Water Resources, Sacramento CA

DWR (2003), California's Groundwater, Bulletin 118, Update 2003, California Department of Water Resources, Sacramento CA

ESI (2007), Guide to Using Groundwater Vistas, Environmental Simulations Inc., P.O. Box 156, Reinhold, PA 17569.

WASY (2007), FEFLOW, Finite Element Subsurface Flow and Transport Simulation System, WASY GmbH Institute for Water Resources Planning and Systems Research, Waltersdorfer Strasse 10512526 Berlin, Germany, http://www.wasy.de/english/ 
Fogg, G. E. (1989), Modeling the Effects of Seepage from Coachella Canal, Salton Sea Area, unpublished report, University of California, Davis

Frick, C. (1921), Extinct vertebrate faunas of the Badlands of Bautista Creek and San Timoteo Caänon, Southern California, Berkeley, CA, University Press, 277-424 pp

Guay, B. E., C. J. Eastoe, R. Bassett, and A. Long, (2006), Identifying sources of groundwater in the lower Colorado River valley, USA, with $\delta 18 \mathrm{O}, \delta \mathrm{D}$, and $3 \mathrm{H}$ : implications for river water accounting, Hydrogeology Journal 14(1), 146-158.

Harbaugh, A.W., E. R. Banta, M.C. Hill, and M.G. McDonald (2000), Modflow-2000, The U.S. Geological Survey Modular Ground-Water Model-User Guide to Modularization Concepts and the Ground-Water Flow Process, Open-File Report 00-92, U.S. Geological Survey, Reston, VA.

Hely, A.G. and E.L Peck (1964) Precipitation, runoff and water loss in the Lower Colorado River - Salton Sea Area, Geological Survey Professional Paper 486-B, pp16.

Imperial County (1997). Imperial County General Plan. July 23.

Ingraham, N. L., and Taylor, B. E. (1991) Light stable isotope systematics of large-scale hydrologic regimes in California and Nevada, Water Resources Research, 27, (1) 77-90.

Kendall, C. and T. B. Coplen, (2001) Distribution of oxygen-18 and deuterium in river waters across the United States. Hydrological Processes. 15(7), 1363-1393.

Ekwurzel, B., P. Schlosser, W. M. Smethie, L. N. Plummer, E. Busenberg, R. L. Michel, R. Weppernig, and M. Stute, (1994), Dating of shallow groundwater - Comparison of the transient tracers ${ }^{3} \mathrm{H} /{ }^{3} \mathrm{He}$, chlorofluorocarbons, and ${ }^{85} \mathrm{Kr}$, Water Resources Research, 30, 1693-1708.

LaBolle, E. M., A, Ayman, and G. E. Fogg, (2003) Review of the Integrated Groundwater and Surface-Water Model (IGSM), Ground Water, vol.41, no.2, pp.238-246.

LeRoy Crandall and Associates (1981), Report of Phase II Investigation, Feasibility of Storing Colorado River Water in Desert Groundwater Basins. Prepared for Metropolitan Water District of Southern California

LeRoy Crandall and Associates (1983), Phase I Hydrogeologic Investigation, Feasibility of Recovering Ground Water in the East Mesa Area, Imperial County, California.

LLNL (2002), Facilitate the California 4.4 Plan: New water, Interim mitigation, Salton Sea reclamation, Energy and Environmental Directorate, Lawrence Livermore National Laboratory, University of California, unpublished draft document

Loeltz, O. J., B. Irelan, J. H. Robison, and F. H. Olmsted (1975), Geohydrologic reconnaissance of the Imperial Valley, California, Geological Survey Professional paper 486-K, US Geological Survey, Washington, DC.

Loeltz, O. J. and S. A. Leake (1979), Relation between proposed developments of water resources and seepage from the All-American Canal, Eastern Imperial County, California, Open File Report 79-744, prepared in cooperation with the US Bureau of Reclamation US Geological Survey, Tucson, AZ.

Massonnet, D., T. Holzer, and H. Vadon (1997), Land subsidence caused by the East Mesa Geothermal Field, California, observed using SAR interferometry, Geophysical. Research Letters, 24 (8), 901-904 
Mallory, M. J., Swain, L. A., and Tyley, S. J. (1980), Potential for using the Upper Coachella Valley ground-water basin, California, for storage of artificially recharged water, U.S. Geological Survey, Open File Report 80-599

Michel, R. L. and R. A. Schroeder, (1994) Use of long-term tritium records from the Colorado River to determine timescales for hydrologic processes associated with irrigation in the Imperial Valley, California, Applied Geochemistry, 9, 387-401.

Mitten, H. T., G. C. Hines, C. Berenbrock, and T. J. Durbin (1988), Water Resources of Borrego Valley and Vicinity, San Diego County, California: Phase 2 - Development of a GroundWater Flow Model. U.S. Geological Survey, Water-Resources Investigations Report 87-4199

Montgomery Watson (1996), County of Imperial, Imperial County Groundwater Study, prepared by Montgomery Watson Inc.

Montgomery Watson (2000), Groundwater and Surface Water in Southern California: A Guide to Conjunctive Use, prepared by Montgomery Watson Inc. for the Association of Ground Water Agencies, Azusa, CA

Moran, J. E. and M. Halliwell, (2003), Characterizing groundwater recharge: A comprehensive isotopic approach. American Water Works Association, final report 90941.

Moran, J. E., G. B. Hudson, G. F. Eaton, and R. Leif, (2002a), A contamination vulnerability assessment for the Livermore-Amador and Niles Cone Groundwater Basins, Lawrence Livermore National Laboratory, Livermore CA (UCRL-AR-148831).

Moran, J. E., G. B. Hudson, G. F. Eaton, and R. Leif, (2002b), A contamination vulnerability assessment for the Santa Clara and San Mateo County Groundwater Basins, Lawrence Livermore National Laboratory, Livermore CA (UCRL-TR-201929).

Moran, J. E., G. B. Hudson, G. F. Eaton, and R. Leif, (2003), A contamination vulnerability assessment for the Sacramento Area Groundwater Basin, Lawrence Livermore National Laboratory, Livermore CA (UCRL-TR-203258).

Moran, J. E., G. B. Hudson, G. F. Eaton, and R. Leif, (2005a), A contamination vulnerability assessment for the Bakersfield Area, Lawrence Livermore National Laboratory, Livermore CA (UCRL-TR-208179).

Moran, J. E., G. B. Hudson, G. F. Eaton, and R. Leif, (2005b), A contamination vulnerability assessment for the Sacramento Valley and northern Volcanic Provinces: Report to the California State Water Resources Control Board, Lawrence Livermore National Laboratory, Livermore CA (UCRL-TR-209191)

Moyle, W. R., Jr., (1982) Water Resources of Borrego Valley and Vicinity, California, Phase IDefinition of Geologic and Hydrologic Characteristics of Basin, U.S. Geological Survey, Open-File Report 82-855, 39 pp

MSWD (2000), Mission Springs Water District Urban Water Management Plan 2000, Mission Springs Water District

MWD/BLM (1999) Cadiz groundwater storage and dry-year supply program: Environmental Planning Technical Report, Groundwater Resources Volumes I and II. Report No.1163. Metropolitan Water District of Southern California and US Bureau of Land Management 
Newmark, R. L., P. W. Kasameyer, and L. W. Younker (1988), Preliminary Report on Shallow Research Drilling in the Salton Sea Region, Lawrence Livermore National Laboratory, Livermore, CA (UCID-21484)

Nitao, J. J. (1995), Reference Manual for the NUFT Flow and Transport Code, Version 1.0 Lawrence Livermore National Laboratory, Livermore, CA (UCRL-ID-113520)

Owen-Joyce, S. J., R. P. Wilson, M. C. Carpenter, and J. B. Fink, (2000), Method to identify wells that yield water that will be replaced by water from the Colorado River downstream from Laguna Dam in Arizona and California: U.S. Geological Survey Water-Resources Investigation 2000-4085, $31 \mathrm{pp}$

Planert, M., and J. S. Williams (1995) Ground Water Atlas of the United States - Segment 1 California Nevada. U. S. Geological Survey Hydrologic Investigations Atlas 730-B., http://capp.water.usgs.gov/gwa/ch_b/index.html

Poeter, E. P. and M. C. Hill (1998), Documentation of UCODE, A Computer Code for Universal Inverse Modeling, U.S. Geological Survey Water-Resources Investigations Report 98-4080, $116 \mathrm{p}$.

Poreda, R.J., Cerling, T.E., and Solomon, D.K., 1988, Tritium and helium isotopes as hydrologic tracers in a shallow unconfined aquifer: Journal of Hydrology, 103, 1-9.

Pruess, K. (1991), TOUGH2 - A General Purpose Numerical Simulator for Multiphase Fluid and Heat Flow, Lawrence Berkeley Laboratory Report LBL-29400, Berkeley, CA.

Reclamation (1989), East Highline Canal Seepage and System Improvement Study, Special Technical Report, US Department of the Interior, Bureau of Reclamation and the Imperial Irrigation District, Imperial County, CA

Reclamation (1993), Coachella Canal Lining Project, Final Environmental Impact Statement; Draft Environmental Impact Statement, Environmental Impact Report, Geohydrology Appendix, US Department of the Interior, Bureau of Reclamation and the Coachella Valley Water District, Riverside and Imperial Counties, CA

Reclamation (1994), All-American Canal Lining Project, Final Environmental Impact Statement; Final Environmental Impact Report, Geohydrology Appendix, US Department of the Interior, Bureau of Reclamation and the Imperial Irrigation District, Imperial County, CA.

Redlands Institute (2002), Salton Sea Atlas, University of Redlands, ESRI Press

Riney, T. D., J. W. Pritchett, and L.F. Rice (1982), Integrated Model of the Shallow And Deep Hydrothermal Systems in the East Mesa Area, Imperial Valley, California, U.S. Geological Survey, Washington DC, Open-File Report 82-980, 118 p.

Schlosser, P., M. Stute, H. Dorr, C. Sonntag, C, and O. Munnich, (1988), Tritium $/{ }^{3}$ He dating of shallow groundwater, Earth, Planetary Science Letters, 89, 353-362.

Setmire, J. G. (1979), Water-Quality Conditions in the New River, Imperial County, California, U.S. Geological Survey Water-Resources Investigations 79-86, 63 pp

SGPWA (2001) Engineer's Report on Water Condition, Reporting Period 1999, San Gorgonio Pass Water Agency, $25 \mathrm{pp}$

Skrivan, J. A. (1977) Digital-Model evaluation of the Ground-Water Resources in the OcotilloCoyote Wells Basin, Imperial County, California U.S. Geological Survey, Water-Resources Investigations 77-30. $50 \mathrm{pp}$ 
Slade, R. (1981), Hydrogeologic Conditions in the Mission Creek Sub basin Upper Coachella Valley, California, in Geology of the San Jacinto Mountains, Annual Field Trip Guidebook No. 9. South Coast Geological Society, pp. 151-163

Slade and Associates LLC (2000) Final Hydrogeologic Evaluation, Well Siting, and Recharge Potential Feasibility Study: Mission Creek Groundwater Sub basin, Riverside County, California, report prepared for ASL Consulting Engineers Pasadena, California and Mission Creek Water District, Desert Hot Springs, California, 59 pp

Solomon, D. K, R. J. Poreda, S. L. Schiff, and J. A. Cherry (1992) Tritium and helium-3 as groundwater age tracers in the Borden aquifer., Water Resources Research, 28, 741-755.

Surano, K. A, G. B. Hudson, R. A. Failor, J. M. Sims, R. C. Holland, S. C. MacLean, and J. C. Garrison (1992), Helium-3 Mass Spectrometry for Low-level Tritium Analysis of Environmental Samples, Journal of Radioanalytical and Nuclear Chemistry, 161, 443.

Swain, L.A. (1978) Predicted Water-Level and Water-Quality Effects of Artificial Recharge in the Upper Coachella Valley, California, Using a Finite-Element Digital Model, US Geological Survey Water Resources Investigations 77-29, 54 pp

Szabo, Z, D. E. Rice, L. N. Plummer, E. Busenberg, S. Drenkard, and P. Schlosser (1996) Age dating of shallow groundwater with chlorofluorocarbons, tritium helium 3, and flow path analysis, southern New Jersey coastal plain: Water Resources Research, 32(4), 1023-1038.

Tetra Tech, Inc (1999), Final Report, A Study on Seepage and Subsurface Inflows to Salton Sea and Adjacent Wetlands

Tompson, A. F. B., S. F. Carle, N. D. Rosenberg, and R. M. Maxwell, (1999), Analysis of groundwater migration from artificial recharge in a large urban aquifer: A simulation perspective, Water Resources Research, 35(10), 2981-2998.

Tompson, A. F. B., D. K. Smith, G. B. Hudson, and J. R. Hunt, JR (2006), Analysis of radionuclide migration through a 200 -m vadose zone following a 16 -year infiltration event, Advances in Water Resources, 29, 281-292

Tyley, S. J (1973), Artificial recharge in the Whitewater River area, Palm Springs, California, US Geological Survey, Washington DC, Open File Report 73-289

Tyley, S. J (1974), Analog Model Study of the Ground-Water Basin of the Upper Coachella Valley, California, US Geological Survey, Washington DC, Water Supply Paper 2027

URS Corporation (2000), Feasibility Assessment Hayfield Lake/Chuckwalla Valley Groundwater Conjunctive-Use Project. Prepared for Metropolitan Water District of Southern California, Volumes I-III

USDA (2007), ROSETTA Class Average Hydraulic Parameters, Agricultural Research Service (ARS), US Salinity Laboratory (USSL), US Department of Agriculture, 450 West Big Springs Road, Riverside, CA 92507 http://www.ars.usda.gov/Services/docs.htm?docid=8955

Weghorst, P. (2001), Salton Sea Accounting Model (Draft), US Bureau of Reclamation, Lower Colorado Region

Wilson, R. P., and S. J. Owen-Joyce (1994), Method to identify wells that yield water that will be replaced by Colorado River water in Arizona, California, Nevada, and Utah, U.S. Geological Survey, Water Resources Investigation Report 94-4005, 36 pp 


\section{Appendix A: \\ Estimation of Precipitation Excess (PE) in the Salton Sea Basin}

\section{A.1 Background}

Local and regional groundwater budget considerations are often expressed in terms of a general vertical mass balance equation of the form

(A.1) $\frac{d W}{d t}=P-E T-R-Q$,

where $\mathrm{W}$ represents groundwater in storage [L] (e.g., in terms of the water table elevation), $t$ is time $[\mathrm{T}], \mathrm{P}$ is the precipitation rate $[\mathrm{L} / \mathrm{T}], \mathrm{ET}$ is the evapotranspiration rate $[\mathrm{L} / \mathrm{T}], \mathrm{R}$ represents a loss rate due to runoff $\left[\mathrm{LT}^{-1}\right]$, and $Q$ is a general source or sink term describing some other anthropogenic influence [L/T] (Figure A1). Equation (A.1) highlights the importance of the difference in precipitation and evapotranspiration rates, $\mathrm{P}-\mathrm{ET}$, in the estimation of water storage changes $d W / d t$, which, in the absence of runoff (R) or other sink (Q), can be considered equivalent to the overall groundwater recharge or discharge rate. The quantity $\mathrm{P}-\mathrm{ET}=\mathrm{PE}$ is defined as the rate of precipitation excess $[\mathrm{mm} / \mathrm{d}]^{8}$

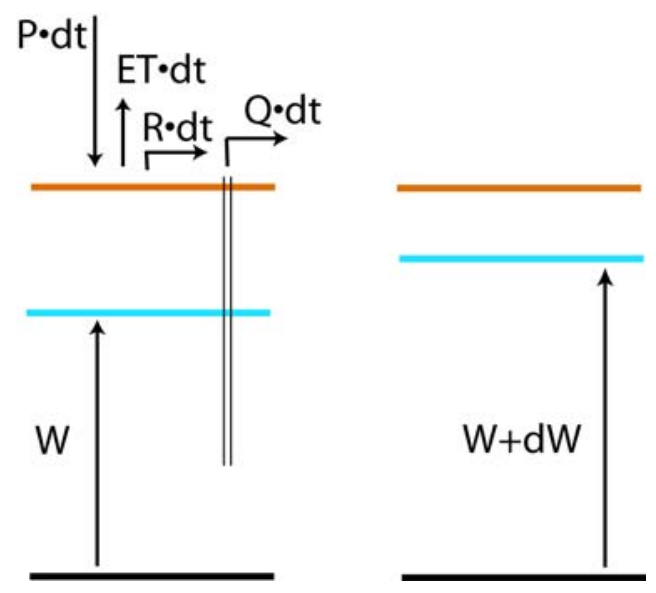

Figure A1: Simple vertical groundwater budget over an increment of time (dt) represented in terms of precipitation rate $P$, evapotranspiration rate $E T$, runoff rate $R$, and an additional source or sink $Q$ (as from a well). Brown represents the ground surface, blue, the water table, and black, the measurement datum.

\footnotetext{
${ }^{8}$ The quantities $\Delta \mathrm{W}_{\mathrm{P}}=P \Delta \mathrm{t}, \Delta \mathrm{W}_{\mathrm{ET}}=E T \Delta \mathrm{t}$, and $\Delta \mathrm{W}_{\mathrm{PE}}=(P-E T) \Delta \mathrm{t}$ are defined as the precipitation, evapotranspiration, and precipitation excess totals $[\mathrm{mm}]$, as accumulated over some time period $\Delta \mathrm{t}$.
} 
In applications, the estimation of PE is of particular concern because of the difficulty in determining spatially distributed time series of the precipitation (P) and evapotranspiration (ET) rates. Precipitation data are commonly available from sparse monitoring (rain gauge) networks. Difficulties arise in the process of spatial interpolation of these data to higher resolution grids that are needed to calculate accurate water budgets. In the case of ET, direct measurements a rarely available - rather, estimates of ET rely on weather data such as temperature and wind speed that are only monitored at the same stations where precipitation is measured. In addition, the dependence of ET on crop type, for example, further complicates the calculation because of land use changes and varying growing cycles in agricultural watersheds.

In the Salton Sea Basin, a considerable amount of work has been done to estimate the spatially distributed components of the water budget in (A.1). For example, Hely and Peck (1964) provided maps of interpolated precipitation, evapotranspiration and runoff rates for the periods October-April and May-September based on weather data collected over a 30-year period between 1931 and 1960. Because of their age, these maps cannot be easily transferred to today's conditions considering land use changes and possible trends in the local weather conditions. In addition, the spatial and temporal resolution in these maps is very coarse and does not capture what is believed to be the true spatial variability in P, ET, and R.

In another study, Montgomery and Watson (1995) utilized a large, numerical model (Integrated Groundwater Surface water Model, or IGSM) to develop spatially distributed estimates of PE over portions of the Salton Sea Basin. Unfortunately, the results cannot be effectively assessed because only limited information is provided in their written report. In addition, the IGSM model is not widely available, and LaBolle et al. (2003) have recently questioned the viability of the solution methods it employs.

\section{A.2 Data, Theory, and ArcGIS Implementation}

More accurate estimates of spatially distributed PE fields can be developed through the use of flexible computational tools that allow for seamless assimilation and manipulation of high-density weather data time series information and spatially distributed land use data. Below, one such improved approach for determining PE will be demonstrated for each month $(m)$ of the year through the use of (i) an ArcGIS computational platform coupled with (ii) a simple model of monthly crop evapotranspiration and (iii) climatic data from the Parameter-elevation Regressions on Independent Slope Model (PRISM) data sets ${ }^{9}$.

The PRISM data sets consist of high-resolution ( $800 \mathrm{~m}$ and $4 \mathrm{~km})$ climatic data interpolated from point measurements using analytical interpolation functions that reflect the influence of topography and rain shadows. In this study the $800 \mathrm{~m}$ resolution averaged precipitation and temperature calculated for the 30-year time period between 1971 and 2000 were used.

Following the Cooperative Extension Service (1997) Fact Sheet, the potential or reference evapotranspiration model of Hargreaves was used to estimate a spatially distributed

\footnotetext{
${ }^{9}$ http://www.ocs.oregonstate.edu/prism
} 
crop evapotranspiration rate $E T_{c}^{m} \equiv E T_{c}^{m}(\mathbf{x})$ for each month $m$ over the entire extent of the Salton Sea Basin watershed (Figures 1.1 and 2.1). The approach is based upon the methods of Allen et al. (1998), the details of which go beyond the scope of this study.

In the current approach, $E T_{c}^{m}$ is calculated from the potential or reference evapotranspiration rate $E T_{0}^{m}[\mathrm{~mm} / \mathrm{d}]$ for each month in the Salton Sea Basin via

$$
\text { (A.2) } E T_{c}^{m}=E T_{0}^{m} k_{c}^{m}
$$

where $k_{c}^{m}(\mathbf{x})$ is a dimensionless, spatially distributed crop coefficient defined for each month $m$.

The Hargreaves model for $E T_{0}^{m}$ can be written as

$$
E T_{0}^{m}=0.0135\left(T^{m}+17.78\right) R_{s}^{m}\left(\frac{238}{595.5-0.55 T^{m}}\right)
$$

where $T^{m}\left[{ }^{\circ} \mathrm{C}\right]$ is the mean monthly temperature and $R_{\mathrm{s}}^{m}\left[\mathrm{MJ} / \mathrm{d} / \mathrm{m}^{2}\right]$ is the incident solar radiation for month $m$.

In turn, the solar radiation $R_{s}^{m}$ was calculated using the Angstrom equation:

$$
\text { (A.4) } \quad R_{s}^{m}=\left(a+b \frac{n^{m}}{N^{m}}\right) R_{a}^{m}
$$

where $\mathrm{a}$ and $\mathrm{b}$ are dimensionless fitting parameters, $n^{m} / N^{m}$ is the ratio of actual sunshine duration to the maximum possible duration of sunshine over daylight hours for month $m$, and $R_{a}^{m}$ is the extraterrestrial radiation $\left[\mathrm{MJ} / \mathrm{d} / \mathrm{m}^{2}\right]$. Where calibration data are not available, Allen et al. (1998) recommend that $\mathrm{a}=0.25$ and $\mathrm{b}=0.5$. Additionally, because of a lack of data, the ratio $n^{m} / N^{m}$ was assumed to be equal to 1 for all months.

The extraterrestrial radiation $R_{a}^{m}$ for month $m$ was calculated using the equation (Allen et al., 1998, eq. 21):

$$
\text { (A.5) } R_{a}^{m}=\frac{24(60)}{\pi} 0.082 d_{r}\left[\omega_{s}^{m} \sin (\varphi) \sin \left(\delta^{m}\right)+\cos (\varphi) \cos \left(\delta^{m}\right) \sin \left(\omega_{s}^{m}\right)\right]
$$

where $d_{r}^{m}$ is the dimensionless inverse Earth-Sun distance, $\omega_{s}^{m}$ is the sunset hour angle [rad], $\delta^{m}$ is the solar declination [rad], all for month $m$, and $\varphi$ is the local latitude [rad] (Allen et al., 1998).

Monthly reference evapotranspiration rates were converted into crop evapotranspiration values using equation (A.2) and the data in Table A.1. To do this, land cover data for the Salton Sea Basin was first obtained from the 2001 National Land Cover Data set at http://www.mrlc.gov (specifically, using file ca_south_NLCD_042800_erd.tif) and subsequently classified into nine groups for which crop coefficients were assigned for each month of the year. The crop coefficients were based on information from http:/www.wateright.org/ shown in Table A.1 below. 
Table A.1. Monthly crop coefficients $\left(k_{c}^{m}\right)$ for the land cover in the Salton Sea Basin

\begin{tabular}{|c|c|c|c|c|c|c|c|c|c|c|c|c|c|}
\hline 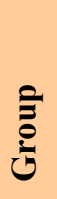 & Crop Name & 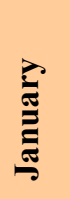 & 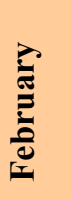 & $\sum_{\bar{E}}^{\bar{J}}$ & $\frac{\overline{2}}{\overline{2}}$ & $\sum_{i}^{\vec{j}}$ & $\stackrel{\Xi}{\Xi}$ & $\frac{\lambda}{\Xi}$ & 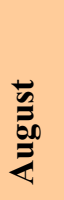 & 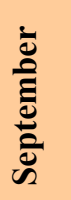 & $\begin{array}{l}\dot{\bar{D}} \\
\frac{0}{0} \\
\stackrel{0}{0}\end{array}$ & 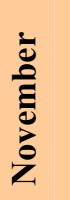 & 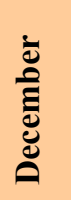 \\
\hline 1 & Open Water & 0.8 & 0.8 & 0.8 & 0.8 & 0.8 & 0.8 & 0.8 & 0.8 & 0.8 & 0.8 & 0.8 & 80 \\
\hline 1 & Perennial Snow & 0.8 & 0.8 & 0.8 & 0.8 & 0.8 & 0.8 & 0.8 & 0.8 & 0.8 & 0.8 & 0.8 & 80 \\
\hline 2 & Low Residential & 1.0 & 1.0 & 1.0 & 1.0 & 1.0 & 1.0 & 1.0 & 1.0 & 1.0 & 1.0 & 1.0 & 1.0 \\
\hline 2 & High Residential & 1.0 & 1.0 & 1.0 & 1.0 & 1.0 & 1.0 & 1.0 & 1.0 & 1.0 & 1.0 & 1.0 & 1.0 \\
\hline 2 & Commercial & 1.0 & 1.0 & 1.0 & 1.0 & 1.0 & 1.0 & 1.0 & 1.0 & 1.0 & 1.0 & 1.0 & 1.0 \\
\hline 3 & Bare Sand & 1.0 & 0.8 & 0.5 & 0.2 & 0.1 & 0.05 & 0.05 & 0.1 & 0.2 & 0.5 & 0.8 & 1.0 \\
\hline 3 & Gravel Pits & 1.0 & 0.8 & 0.5 & 0.2 & 0.1 & 0.05 & 0.05 & 0.1 & 0.2 & 0.5 & 0.8 & 1.0 \\
\hline 3 & Transitional & 1.0 & 0.8 & 0.5 & 0.2 & 0.1 & 0.05 & 0.05 & 0.1 & 0.2 & 0.5 & 0.8 & 1.0 \\
\hline 4 & $\begin{array}{l}\text { Deciduous } \\
\text { Forest }\end{array}$ & 1.2 & 1.0 & 0.6 & 0.25 & 0.1 & 0.05 & 0.05 & 0.1 & 0.2 & 0.5 & 0.8 & 1.0 \\
\hline 4 & Evergreen Forest & 1.2 & 1.0 & 0.6 & 0.25 & 0.1 & 0.05 & 0.05 & 0.1 & 0.2 & 0.5 & 0.8 & 1.0 \\
\hline 4 & Mixed Forest & 1.2 & 1.0 & 0.6 & 0.25 & 0.1 & 0.05 & 0.05 & 0.1 & 0.2 & 0.5 & 0.8 & 1.0 \\
\hline 5 & Shrub & 1.1 & 0.9 & 0.55 & 0.25 & 0.1 & 0.05 & 0.05 & 0.1 & 0.2 & 0.5 & 0.8 & 1.0 \\
\hline 6 & $\begin{array}{l}\text { Non-Natural } \\
\text { Woody }\end{array}$ & 1.1 & 1.1 & 1.1 & 1.1 & 1.1 & 1.1 & 1.1 & 1.1 & 1.1 & 1.1 & 1.1 & 1.1 \\
\hline 7 & Grasslands & 1.1 & 0.9 & 0.55 & 0.25 & 0.1 & 0.05 & 0.05 & 0.1 & 0.2 & 0.5 & 0.8 & 1.0 \\
\hline 8 & Pasture & 1.0 & 1.0 & 1.0 & 1.0 & 1.0 & 1.0 & 1.0 & 1.0 & 1.0 & 1.0 & 1.0 & 1.0 \\
\hline 8 & Row Crops & 1.0 & 1.0 & 1.0 & 1.0 & 1.0 & 1.0 & 1.0 & 1.0 & 1.0 & 1.0 & 1.0 & 1.0 \\
\hline 8 & Small Grains & 1.0 & 1.0 & 1.0 & 1.0 & 1.0 & 1.0 & 1.0 & 1.0 & 1.0 & 1.0 & 1.0 & 1.0 \\
\hline 8 & Fallow & 1.0 & 1.0 & 1.0 & 1.0 & 1.0 & 1.0 & 1.0 & 1.0 & 1.0 & 1.0 & 1.0 & 1.0 \\
\hline 8 & Urban & 1.0 & 1.0 & 1.0 & 1.0 & 1.0 & 1.0 & 1.0 & 1.0 & 1.0 & 1.0 & 1.0 & 1.0 \\
\hline 8 & Grasses & 1.0 & 1.0 & 1.0 & 1.0 & 1.0 & 1.0 & 1.0 & 1.0 & 1.0 & 1.0 & 1.0 & 1.0 \\
\hline 9 & Woody Wetlands & 1.0 & 1.0 & 1.0 & 1.0 & 1.0 & 1.0 & 1.0 & 1.0 & 1.0 & 1.0 & 1.0 & 1.0 \\
\hline 9 & $\begin{array}{l}\text { Herbaceous } \\
\text { Wetlands }\end{array}$ & 1.0 & 1.0 & 1.0 & 1.0 & 1.0 & 1.0 & 1.0 & 1.0 & 1.0 & 1.0 & 1.0 & 1.0 \\
\hline
\end{tabular}

In the final step of the study, the spatially distributed precipitation [mm], precipitation excess rate $[\mathrm{mm} / \mathrm{d}]$, and total recharge $[\mathrm{mm}]$ were calculated over the entire watershed for each month and for a whole year using the monthly climatic precipitation rates, averaged over the period 1971-2000, from the PRISM database.

Specifically, the following quantities were calculated on a $1 \mathrm{~km}$ square grid over the Salton Sea Watershed Basin, where $\Delta t$ represents the time increment [d] for each month:

The total monthly precipitation $[\mathrm{mm}]$ at each spatial location,

(A.6) $\Delta W_{P}^{m} \sim P^{m} \Delta t$; 
The total monthly precipitation excess $[\mathrm{mm}]$ at each spatial location ${ }^{10}$,

$$
\text { (A.7) } \Delta W_{P E}^{m} \sim\left\|P^{m}-E T_{0}^{m} k_{c}^{m}\right\| \Delta t,
$$

The total annual precipitation $[\mathrm{mm}]$ at each spatial location,

$$
\text { (A.8) } \Delta W_{P}=\sum_{m} \Delta W_{P}^{m} \sim \sum_{m} P^{m} \Delta t \text {, and }
$$

The total annual precipitation excess $[\mathrm{mm}]$ at each spatial location,

(A.9) $\Delta W_{P E}=\sum_{m} \Delta W_{P E}^{m} \sim \sum_{m}\left\|P^{m}-E T_{0}^{m} k_{c}^{m}\right\| \Delta t$.

Figure 2.7 shows a contour plot of the total average annual precipitation [mm] over the Salton Sea Basin watershed as obtained from (A.8) using average data from 1971-2000 resolved onto a $1 \mathrm{~km}^{2}$ grid. The maximum precipitation amounts are clearly clustered along the western and northwestern mountain fronts surrounding the basin.

Figure A.1 shows a contour plot of the total precipitation excess [mm] over the Salton Sea Basin watershed for the month of January, as calculated from (A.7) and averaged January data obtained between 1971-2000 and resolved onto a $1 \mathrm{~km}^{2}$ grid. Figure A.2 shows a similar plot for obtained the entire year using (A.9) and the averaged annual data between 1971-2000. Although these quantities do not represent recharge values per se, because surface runoff $(\mathrm{R})$ and other losses (Q) in (A.1) were not taken into account, they do suggest that the mountain front areas on the west side of the basin would be the locus of considerable recharge, especially during the winter months.

The total, area-integrated volumes of precipitation and precipitation excess water accrued over some area $A$ in the watershed on a monthly or annual basis can be determined by integrating (A.6) through (A.9) over A, e.g.,

(A.10) $\Delta W_{P}^{\text {Area }}=\int_{A} \Delta W_{P} d A$, and

(A.11) $\Delta W_{P E}^{\text {Area }}=\int_{A} \Delta W_{P E} d A$.

\section{A.2.1 Precipitation Excess in the Salton Sea Watershed Basin}

Tables A.2 and A.3 present evaluations of (A.10) and (A.11) for monthly and annual scenarios over the entire basin watershed, as shown in Figures 1.1 and 2.1. These results include extrapolated data for the Mexico portion of the watershed. As such, these results indicate that

- The integrated raw precipitation over the watershed basin in the US, including the Salton Sea proper, amounts to approximately 2.5 MAF on an average annual basis. This represents approximately $1 \%$ of the precipitation falling over all of California per year.

\footnotetext{
${ }^{10}$ Here, the operator $\|\bullet\|$ is used to denote the magnitude of the term within it $(\bullet)$ if it is positive and 0 otherwise, as potential evapotranspitation rates can often be higher that precipitation rates.
}

115 


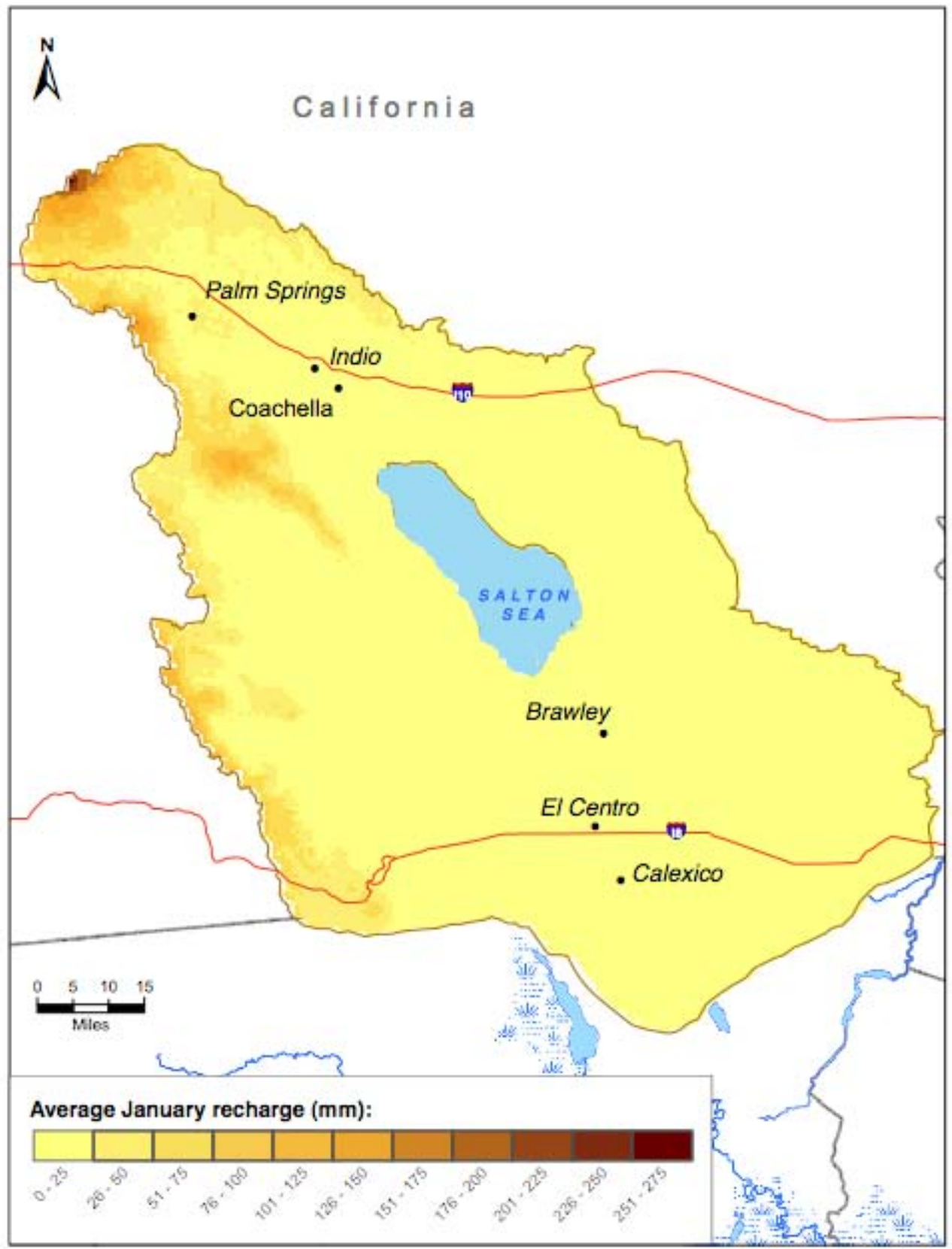

Figure A.1: Total precipitation excess in the Salton Sea watershed for the month of January, $\Delta W_{P E}^{\text {January }}[\mathrm{mm}]$, as calculated from (A.7) using the climatic normal data from 1991-2000 for the month of January. Recall, these do not reflect the effects of runoff (R) or other losses. 


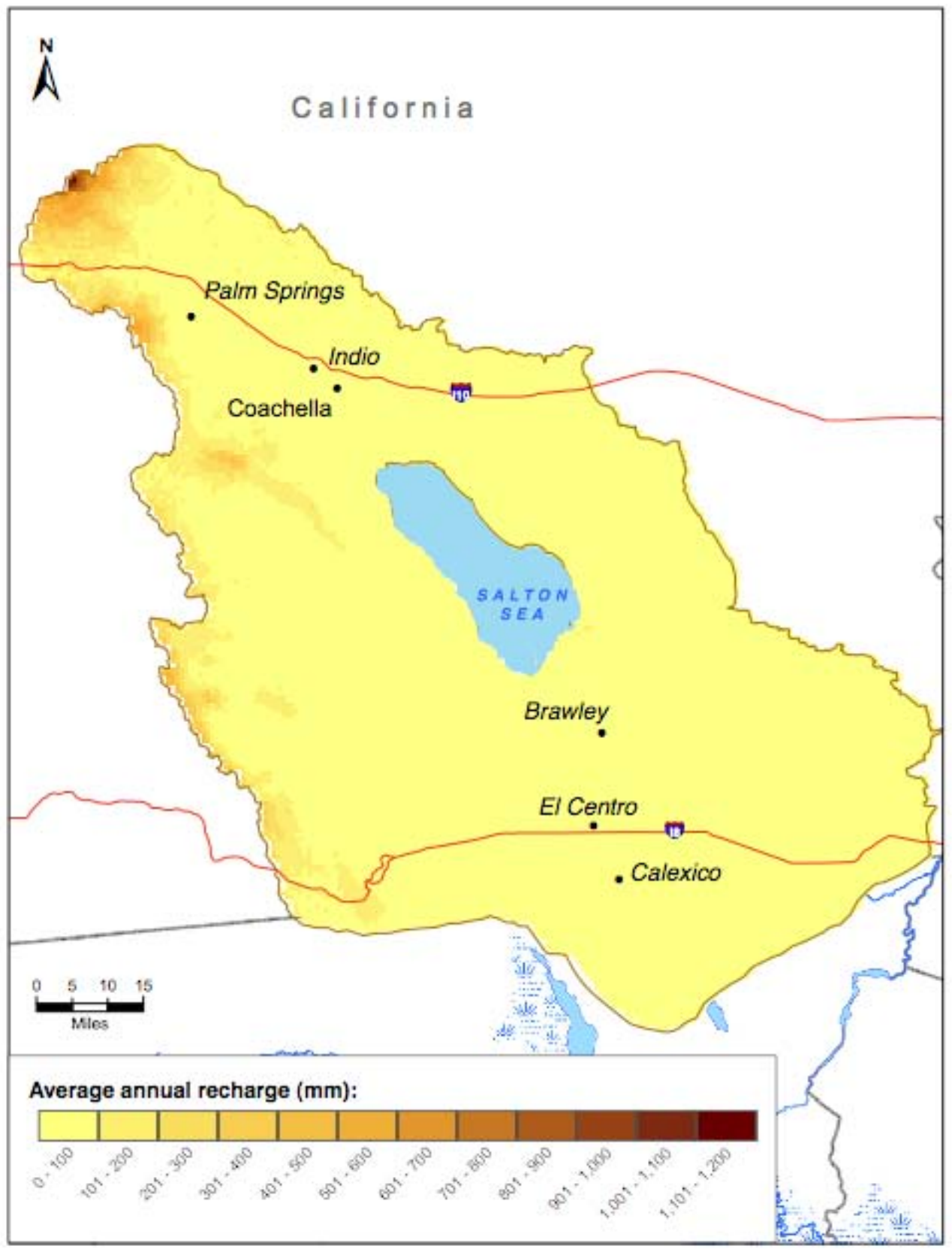

Figure A.2: Total annual precipitation excess, $\Delta W_{P E}[\mathrm{~mm}]$ in the Salton Sea watershed, as calculated from (A.7) using averaged climatic normal data between 19912000. Recall, these do not reflect the effects of runoff $(R)$ or other losses. 
Table A.2: Volumetric Precipitation estimates in Salton Sea Basin

\begin{tabular}{lrr}
\hline \hline \multicolumn{1}{c}{ Month } & Precipitation $\left[\mathbf{m}^{\mathbf{3}}\right]$ & Precipitation [AF] \\
\hline January & $460,742,181$ & 373,530 \\
February & $415,611,350$ & 336,942 \\
March & $404,848,561$ & 328,216 \\
April & $135,899,787$ & 110,176 \\
May & $52,405,939$ & 42,486 \\
June & $12,169,395$ & 9,866 \\
July & $164,954,447$ & 133,731 \\
August & $298,412,182$ & 241,927 \\
September & $231,810,117$ & 187,932 \\
October & $189,247,098$ & 153,425 \\
November & $306,145,447$ & 248,196 \\
December & $415,589,170$ & 336,924 \\
\hline \multicolumn{2}{c}{ TOTAL } & $\mathbf{3 , 0 8 7 , 8 3 5 , 6 7 3}$ \\
\hline
\end{tabular}

Table A.3: Volumetric Precipitation and Precipitation Excess estimates in Salton Sea Basin, neglecting the area of the Sea and runoff losses.

\begin{tabular}{lrrrr}
\hline \hline \multicolumn{1}{c}{ Month } & $\begin{array}{c}\text { Precipitation } \\
{\left[\mathbf{m}^{\mathbf{3}} \mathbf{]}\right.}\end{array}$ & $\begin{array}{c}\text { Precipitation } \\
\text { Excess }\left[\mathbf{m}^{\mathbf{3}}\right]\end{array}$ & $\begin{array}{c}\text { Precipitation } \\
\text { [AF] }\end{array}$ & $\begin{array}{c}\text { Precipitation } \\
\text { Excess [AF] }\end{array}$ \\
\hline January & $451,632,579$ & $216,185,459$ & 366,144 & 175,264 \\
February & $407,399,011$ & $178,855,918$ & 330,284 & 145,001 \\
March & $397,767,097$ & $82,285,808$ & 322,475 & 66,710 \\
April & $133,696,444$ & $1,033,997$ & 108,389 & 838 \\
May & $51,673,751$ & 35,890 & 41,893 & 29 \\
June & $11,545,137$ & 23,627 & 9,360 & 19 \\
July & $160,377,705$ & 39,375 & 130,020 & 32 \\
August & $290,658,278$ & 75,519 & 235,641 & 61 \\
September & $224,480,979$ & 83,660 & 181,990 & 68 \\
October & $183,057,202$ & 632,321 & 148,407 & 513 \\
November & $299,601,739$ & $13,645,707$ & 242,891 & 11,063 \\
December & $407,402,109$ & $70,561,373$ & 330,286 & 57,205 \\
\hline \multicolumn{1}{c}{ TOTAL } & $\mathbf{3 , 0 1 9 , 2 9 2 , 0 3 1}$ & $\mathbf{5 6 3 , 4 5 8 , 6 5 3}$ & $\mathbf{2 , 4 4 7 , 7 8 0}$ & $\mathbf{4 5 6 , 8 0 3}$ \\
\hline \hline
\end{tabular}




\begin{tabular}{|c|c|c|c|c|c|c|c|c|c|c|c|c|c|}
\hline Area & 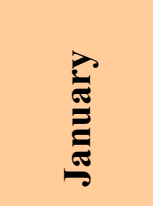 & 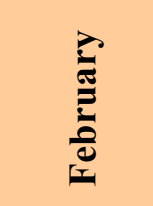 & 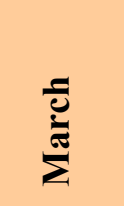 & $\frac{\pi}{2}$ & $\vec{z}$ & $\stackrel{\Xi}{\Xi}$ & $\underline{3}$ & 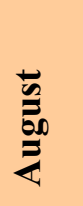 & $\frac{\grave{\Xi}}{0}$ & $\frac{\grave{\Xi}}{\frac{0}{0}}$ & 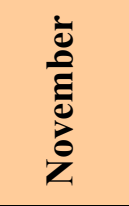 & 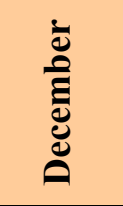 & TOTAL \\
\hline \multicolumn{14}{|c|}{ Groundwater Basins (US only) } \\
\hline Amos Valley & 0 & 0 & 0 & 0 & 0 & 0 & 0 & 0 & 0 & 0 & 0 & 0 & $\mathbf{0}$ \\
\hline Arroyo Seco Valley & 13 & 0 & 0 & 0 & 0 & 0 & 0 & 0 & 0 & 0 & 0 & 4 & 17 \\
\hline Borrego Valley & 169 & 20 & 0 & 0 & 0 & 0 & 0 & 0 & 0 & 0 & 0 & 1 & 189 \\
\hline Chocolate Valley & 116 & 60 & 4 & 0 & 0 & 0 & 0 & 0 & 0 & 0 & 0 & 8 & 188 \\
\hline Ocotillo-Clark Valley & 543 & 146 & 0 & 0 & 0 & 0 & 0 & 0 & 0 & 0 & 0 & 41 & 730 \\
\hline Coyote Wells Valley & 80 & 6 & 0 & 0 & 0 & 0 & 0 & 0 & 0 & 0 & 0 & 4 & 89 \\
\hline East Salton Sea Basin & 112 & 48 & 6 & 0 & 0 & 0 & 0 & 0 & 0 & 0 & 0 & 11 & 177 \\
\hline West Salton Sea Basin & 188 & 113 & 6 & 0 & 0 & 0 & 0 & 0 & 0 & 0 & 0 & 9 & 315 \\
\hline $\begin{array}{l}\text { Vallecito-Carrizo Valley } \\
\text { Coachella Valley ŠŃ ŠŠS }\end{array}$ & 1,218 & 574 & 96 & 0 & 0 & 0 & 0 & 0 & 0 & 0 & 1 & 124 & 2,014 \\
\hline Mission Creek & 3,328 & 2,273 & 216 & 0 & 0 & 0 & 0 & 0 & 0 & 0 & 0 & 194 & 6,010 \\
\hline $\begin{array}{r}\text { Coachella Valley ŠŃ ŠŠS } \\
\text { Desert Hot Springs } \\
\text { Coachella Valley Š́ ŠS }\end{array}$ & 1,585 & 651 & 53 & 0 & 0 & 0 & 0 & 0 & 0 & 0 & 0 & 64 & 2,353 \\
\hline Indio \& San Gorgonio & 13,457 & 11,353 & 4,541 & 11 & 0 & 0 & 0 & 0 & 0 & 6 & 296 & 2,511 & 32,175 \\
\hline Orocopia Valley & 13 & 0 & 0 & 0 & 0 & 0 & 0 & 0 & 0 & 0 & 0 & 0 & 13 \\
\hline Ogilby Valley* & 0 & 0 & 0 & 0 & 0 & 0 & 0 & 0 & 0 & 0 & 0 & 0 & $\mathbf{0}$ \\
\hline Imperial Valley & 316 & 124 & 83 & 16 & 17 & 19 & 32 & 53 & 46 & 49 & 19 & 112 & 885 \\
\hline SUBTOTAL: BASINS & 21,138 & 15,368 & 5,005 & 27 & 17 & 19 & 32 & 53 & 46 & 55 & 316 & 3,083 & 45,155 \\
\hline \multicolumn{14}{|c|}{ Watershed Excluding Groundwater Basins (US + Mexico) } \\
\hline & 154,126 & 129,635 & 61,706 & 811 & 12 & 0 & 0 & 8 & 22 & 458 & 10,746 & 54,123 & 411,648 \\
\hline \multicolumn{14}{|c|}{ Salton Sea Area } \\
\hline & 4,908 & 1,579 & 54 & 4 & 3 & 3 & 9 & 18 & 23 & 20 & 14 & 142 & 5,967 \\
\hline TOTAL: WATERSHED & 179,362 & 146,582 & 66,765 & 842 & 32 & 22 & 41 & 79 & 91 & 533 & 11,076 & 57,348 & 462,770 \\
\hline \multicolumn{14}{|c|}{ Groundwater Model Domain (US + Mexico) } \\
\hline & 2,888 & 761 & 112 & 18 & 18 & 20 & 36 & 62 & 54 & 61 & 23 & 196 & 4,249 \\
\hline
\end{tabular}

Table A.4: Volumetric Precipitation Excess (PE) estimates in the groundwater basins within the Salton Sea Watershed, neglecting the area of the Sea and runoff losses [AF]. *Ogilby Valley excluded in Table 2.3. Groundwater model domain described in Section 7; Mexico coverage extrapolated from data on the US side of the border. 
- The integrated raw precipitation over the Salton Sea itself amounts to approximately 55,500 AF on an average annual basis.

- The integrated precipitation excess over the watershed basin amounts to approximately $456,000 \mathrm{AF}$ on an average annual basis. In some sense, this may be considered as an upper bound for total recharge over the basin, although it exceeds by a factor of 6 the estimated total derived from the DWR (2003) data summarized in Table 2.3.

- That said, a portion of the precipitation excess at each location would occur (instead) as runoff that is redistributed or routed to lower elevations in the basin. Although still contained within the basin as a whole, and remain available for recharge elsewhere, the redistributed precipitation excess will reach lower areas with greater potential evapotranspiration, suggesting a total recharge value lower than the upper bound estimate listed above.

\section{A.2.2 Precipitation Excess in the Groundwater Basins in the Salton Sea Area}

Table A.4 presents evaluations of (A.10) and (A.11) for monthly and annual scenarios over the each separate US groundwater basin in the watershed area, as described in Table 2.3 and illustrated Figure 2.6, as well as those portions of the watershed basin lying outside these groundwater basins. As such, these results indicate that

- The integrated precipitation excess over the groundwater basins themselves amounts to approximately 45,000 AF on an average annual basis, roughly $10 \%$ of that falling over the watershed as a whole. This total for the groundwater basins is $40 \%$ smaller than the estimated recharge of 75,000 AF/y derived from the DWR (2003) data summarized in Table 2.3, but excludes the possibility of additional recharge derived from mountain front runoff. Individual basin totals are similarly comparable with the recharge estimates in Table 2.3.

- The largest raw precipitation excess values occur in the Coachella Valley (including the San Gorgonio, Indio, Mission Creek, and Desert Hot Springs sub basins) and VallecitoCarrizo Valley groundwater basins, all lying on the western and northwestern sides of the basin. The next largest PE values are reported for the Imperial, Ocotillo-Clark Valley, and West Salton Sea basins.

- The potential for recharge in some groundwater basins may actually be larger than the PE values indicated in Table A.4 because of runoff derived from adjacent, higher elevation areas in the watershed, outside of the groundwater basins proper, where precipitation is most concentrated. This will most likely occur in the Coachella Valley and VallecitoCarrizo Valley groundwater basins, as well as to some extent in the Ocotillo-Clark Valley, West Salton Sea, Borrego Valley, and Coyote Wells basins. Additional runoff may be subject to greater fractional ET losses, but will also contribute to increased recharge that may support groundwater production in excess of what the data in Table A.4 may suggest. As an example, raw precipitation in the Vallecito-Carrizo Valley groundwater basin and its associated upgradient watershed is close to $60,000 \mathrm{AF} / \mathrm{y}$. This is much higher than the estimated precipitation excess $(\mathrm{PE})$ value of $2,000 \mathrm{AF} / \mathrm{y}$ in the Vallecito-Carrizo Valley groundwater basin alone, and the actual recharge value in the 
basin, when runoff is taken into account, will likely lie somewhere in between these values.

\section{A.2.3 Precipitation Excess in the Groundwater Model Domain}

Table A.4 presents evaluations of (A.10) and (A.11) for monthly and annual scenarios over the groundwater model domain introduced and discussed in Section 5. The domain includes the principal groundwater basins in the southern half of the basin, primarily those in Imperial and San Diego counties, and portions of the Mexicali Valley in Mexico. Data for the Mexico portion of the model domain was extrapolated southward from data along the US-Mexico border. As such, these results indicate that

- The integrated precipitation excess of 4,249 AF/y over the model domain is quite low, especially when compared with values obtained for basins in the north or directly proximate to the higher precipitation and $\mathrm{PE}$ areas in the mountains bounding the west side of the basin. It is somewhat larger than the 1,000 AF/y precipitation recharge value proposed by Tetra Tech (1999) and is overshadowed by potential recharge from irrigation (Table 2.3).

\section{A.2.4 Average Reference Evapotranspiration Rate in the Imperial Basin}

An average, reference evapotranspiration rate, $E T_{\mathrm{c}}$, Imperial was calculated for the whole of the Imperial Basin for the groundwater model discussed in Section 7 as a means of estimating potential recharge (if any) under irrigated crop lands. This calculation involved the following steps:

The monthly, reference evapotranspiration value [L] defined at each point in the basin

(A.12) $\Delta W_{E T}^{m} \sim E T_{0}^{m} k_{c}^{m} \Delta t$

is (i) integrated over the area of the Imperial Basin, (ii) summed over each month of the year, and

(iii) renormalized by the total basin area, $A_{\text {Imperial }}$, and a one-year time frame, $T_{1-\text { year }}$, to yield

(A.13) $\langle E T\rangle_{c}^{\text {Imperial }} \sim \frac{1}{A_{\text {Imperial }} T_{1-\text { year }}} \sum_{m} \int_{\text {Imperial }} \Delta W_{E T}^{m} d A$

This yields an area- and time-weighted total reference ET value (in $\mathrm{ft} / \mathrm{y}$ ) for the Imperial Basin of (A.14) $\langle E T\rangle_{c}^{\text {Imperial }} \sim 3.85 \mathrm{ft} / \mathrm{y}$.

\section{A.3 Potential Improvements}

The current study serves as a demonstration of how publicly available data can be used to develop spatially distributed maps of precipitation excess (PE) that would be useful in water resources evaluation and groundwater modeling. Naturally this study is based on simplifying assumptions and approximations that could be used to guide future improvements.

1. Atmospheric data: The spatially distributed precipitation data (from PRISM) was developed from an analytical interpolation scheme that should be checked and juxtaposed with other approaches. In case of precipitation, radar-based (NEXRAD) data may serve 
as an alternative source of spatially distributed precipitation information. Moreover, the mean temperature used in the calculations was determined as the arithmetic mean of the maximum and minimum temperature; this is common practice for diurnal data sets but might be problematic for monthly data sets, and could be improved.

2. ET model: The Hargreaves model is a simple temperature-based technique for estimating evaportanspiration. The necessary input data were calculated from ad-hoc equations. The relative sunshine duration, assumed equal to 1 , should be modified for improved accuracy. The results of this approach should be checked with more sophisticated technique, such as the Pennman-Monteith model (Allen, et al., 1998).

3. Land cover data: The land cover data is non-dynamic. Land cover maps that reflect seasonal changes could potentially improve the estimates, even though these changes would be minimal in the mountains where precipitation excess (PE) is the largest. The root water uptake and evaporation rates, which are reflected in the crop coefficient curves, were approximated from simple data available on the web. Although careful improvements could be implemented, the results may not change significantly.

4. Runoff and routing: The lack of any runoff and routing component in the precipitation excess calculations is a significant approximation in the overall basin recharge estimation process. Inclusion of (i) runoff and (ii) routing model components in the basin wide analysis (e.g., in the ArcGIS environment, or through a direct model as in Bevin, 2001) would provide reasonable quantitative estimates of how precipitation, primarily concentrated in the higher elevations on the west side of the basin, is redistributed for infiltration and evapotranspiration elsewhere, or for discharge into the Salton Sea. Runoff is a process clearly observed to occur in these areas. 


\section{Appendix B: \\ Current Reference Literature Database}

\begin{tabular}{|c|c|c|}
\hline Author & Title & Category \\
\hline $\begin{array}{l}\text { Setmire, J.G.; Schroeder, R.A.; Densmore, } \\
\text { J.N.; Goodbred, S.L.; Audet, D.J.; Radke, } \\
\text { W.R. }\end{array}$ & $\begin{array}{l}\text { Detailed study of water quality, bottom sediment, and biota associated with } \\
\text { irrigation drainage in the Salton Sea area, California, 1988-1990 }\end{array}$ & Canal and Irrigation Reports \\
\hline Setmire, J.G.; Wolfe, J.C.; Stroud, R.K. & $\begin{array}{l}\text { Reconnaissance investigation of water quality, bottom sediment, and biota } \\
\text { assoctiated with irrigation drainage in the Salton Sea area, California, 1986-87 }\end{array}$ & Canal and Irrigation Reports \\
\hline Schroeder, R.A., Rivera, M., et al & $\begin{array}{l}\text { Physical, chemical, and biological data from detailed study of irrigation drainage in } \\
\text { the Salton Sea Area, California, 1988-1990. }\end{array}$ & Canal and Irrigation Reports \\
\hline Watt, D. & $\begin{array}{l}\text { Coachella Canal Lining Project, Riverside and Imperial Counties, California, Draft } \\
\text { EID/EIR, Geohydrology Appendix }\end{array}$ & Canal and Irrigation Reports \\
\hline Watt, D. & $\begin{array}{l}\text { All-American Canal Lining Project, Imperial County, California; Final } \\
\text { Environmental Impact Statement/Final Environmental Impact Report, } \\
\text { Geohydrology Appendix }\end{array}$ & Canal and Irrigation Reports \\
\hline Imperial Irrigation District & Map of All American Canal & Canal and Irrigation Reports \\
\hline Imperial Irrigation District & How it works - the All-American Canal & Canal and Irrigation Reports \\
\hline U.S. Bureau of Reclamation & Boulder Canyon Project - All American Canal System & Canal and Irrigation Reports \\
\hline U.S. Bureau of Reclamation & All-American Canal Lining Project, Supplemental Information Report & Canal and Irrigation Reports \\
\hline U.S. Department of the Interior & $\begin{array}{l}\text { Final Environmental Impacts Statement/Final Environmental Impact Report, All } \\
\text { American Canal Lining Project, Imperial County, California, March } 1994\end{array}$ & Canal and Irrigation Reports \\
\hline USBR and Coachella Valley Water District & $\begin{array}{l}\text { Coachella Canal Lining Project, Final Environmental Impact } \\
\text { Statement/Environmental Impact Report, Volume I and attachments }\end{array}$ & Canal and Irrigation Reports \\
\hline USBR and Coachella Valley Water District & $\begin{array}{l}\text { Coachella Canal Lining Project, Final Environmental Impact } \\
\text { Statement/Environmental Impact Report, Volume I and attachments }\end{array}$ & Canal and Irrigation Reports \\
\hline Schroeder, R.A. & $\begin{array}{l}\text { Chemical data for detailed studies of irrigation drainage in the Salton Sea area, } \\
\text { California, 1995-2001 }\end{array}$ & Canal and Irrigation Reports \\
\hline Munguia, V.S. & $\begin{array}{l}\text { The U.S.-Mexico border environment, lining the All-American Canal: competiton or } \\
\text { cooperation for the water in the U.S.-Mexican border? }\end{array}$ & Canal and Irrigation Reports \\
\hline
\end{tabular}

Ground Water Availability within the Salton Sea Basin: A Final Report Lawrence Livermore National Laboratory 


\begin{tabular}{|c|c|c|}
\hline $\begin{array}{l}\text { Metropolitan Water District of Southern } \\
\text { California }\end{array}$ & $\begin{array}{l}\text { Response to: July 9, } 1999 \text { Final Report entitled A study on seepage and subsurface } \\
\text { inflows to Salton Sea an adjacent wetlands (Seepage Study) }\end{array}$ & Canal and Irrigation Reports \\
\hline $\begin{array}{l}\text { U.S. Bureau of Reclamation, Lower } \\
\text { Colorado Region }\end{array}$ & Colorado river system consumptive uses and losses report 1971-1975 & Colorado River \\
\hline $\begin{array}{l}\text { U.S .Bureau of Reclamation, Lower } \\
\text { Colorado River }\end{array}$ & Colorado river system consumptive uses and losses report 1976-1980 & Colorado River \\
\hline U.S. Bureau of Reclamation & Colorado river system consumptive uses and losses report 1981-1985 & Colorado River \\
\hline U.S. Bureau of Reclamation & Colorado river system consumptive uses and losses report 1986-1990 & Colorado River \\
\hline U.S. Bureau of Reclamation & Colorado river system consumptive uses and losses report $1996-2000$ & Colorado River \\
\hline Cohen, M.J., and Henges-Jenk, C. & Missing Water: The uses and flows of water in the Colorado River Delta Region & Colorado River \\
\hline $\begin{array}{l}\text { Cohen, M.J., Henges-Jeck, C. and Castillo- } \\
\text { Moreno, G. }\end{array}$ & A preliminary water balance for the Colorado River delta, 1992 - 1998 & Colorado River \\
\hline Owen-Joyce, S.J. & $\begin{array}{l}\text { Accounting for Consumptive Use of Lower Colorado River Water in Arizona, } \\
\text { California, Nevada, and Utah }\end{array}$ & Colorado River \\
\hline USGS & Increased Selenium Levels in Lower Colorado River Organisms & Colorado River \\
\hline Cohen, M.J. & $\begin{array}{l}\text { Understanding flows through the remnant Colorado River Delta, recommendations } \\
\text { for streamgage sites and data collection }\end{array}$ & Colorado River \\
\hline Bureau of Reclamation & River mile index & Colorado River \\
\hline Southwest Hydrology & The re-emergence of the Colorado River Delta & Colorado River \\
\hline USGS & Climatic fluctuations, drought, and flow in the Colorado River & Colorado River \\
\hline $\begin{array}{l}\text { U.S. Department of the Interior Fish \& } \\
\text { Wildlife Service }\end{array}$ & Saving the Salton Sea; a research needs assessment & Ecology \\
\hline Imperial Irrigation District & Crop Survey, 2006 & Ecology \\
\hline U.C. Riverside workshop panel & $\begin{array}{l}\text { Effects of salt precipitation on historical and projected salinities of the Salton Sea: } \\
\text { Summary comments from workshop at the University of California, Riverside: } \\
\text { January } 30-31,2001\end{array}$ & Ecology \\
\hline U.S. Department of Agriculture & $\begin{array}{l}\text { California, State and County data, Volume 1, Geographic Area Series, Part 5, } 2002 \\
\text { Census of Agriculture }\end{array}$ & Ecology \\
\hline CH2M Hill & Salton Sea Ecosystem Management Plan, Intial Draft Report & Ecology \\
\hline CH2M Hill & $\begin{array}{l}\text { Salton Sea ecosystem restoration plan Task Order No. 17, Task } 3 \text { - Evaluate, } \\
\text { identify gaps, and provide management of current aerometric monitoring data } \\
\text { collection efforts }\end{array}$ & Ecology \\
\hline Cohen, M.J. and K.H. Hyun & Hazard, the future of the Salton Sea with no restoration project & Ecology \\
\hline
\end{tabular}

Ground Water Availability within the Salton Sea Basin: A Final Report Lawrence Livermore National Laboratory 
Cohen, M.J.

Dutcher, L.C, . Hardt, W.F and Moyle, Jr.,

W.R.

U.S. Bureau of Reclamation

U.S. Bureau of Reclamation

Lawrence Berkeley Laboratory, Earth Science Division

Meidav, Tsvi; Rex, R.W.

Rex, R.W, et al

U.S. Bureau of Reclamation

U.S. Bureau of Reclamation; Dodd, J.S.

U.S. Bureau of Reclamation

U.S. Bureau of Reclamation

DOGGR

DOGGR

DOGGR

DOGGR

DOGGR

DOGGR

DOGGR

Paillet, Frederick L.

Kennecottt

Kennecottt

Kennecottt

Kennecott
Integrated water management plan evaluation; a review of the Salton Sea Authority's preferred project concept for rehabilitating the Salton Sea

Ecology

Preliminary appraisal of ground water in storage with reference to geothermal

resources in the Imperial Valley Area, California

Geothermal resource investigations, Imperial Valley, California

Geothermal resource investigations, Imperial Valley, California

Geothermal

Geothermal resource and reservoir investigations of U.S. Bureau of Reclamation

leasholds at East Mesa, Imperial Valley, California

Geothermal

Geothermal

Cooperative investigation of geothermal resources in the Imperial Valley and their potential value for desalination of water and electricity production

Geothermal

Cooperative investigation of geothermal area and their potential value for desalting of water and other purposes

Geothermal Resource Investigations, East Mesa Test Site, Imperial Valley,

California

Geothermal reservoir and production engineering, Mesa Field, Imperial Valley,

California

Geothermal resource investigations, East Mesa Test Site, concluding report, Parts I and II, Imperial Valley, California

Geothermal resource investigations, East Mesa Test Site, concluding report, Parts I and II, Imperial Valley, California

Geothermal Map of Brawley, Imperial County, California Geothermal

Geothermal Map of California

Geothermal Map of East Mesa, Imperial County, California

Geothermal Map of Heber, Imperial County, California

Geothermal Map of Mesquite, Imperial County, California

Geothermal Map of Salton Sea (North Half), Imperial County, California

Geothermal Map of Salton Sea (South Half), Imperial County, California

Geothermal

Geothermal

Geothermal

Geothermal

Geothermal

Geothermal

Geothermal

Geothermal

Geothermal

Geothermal

Geothermal

Geothermal

Preliminary report on geophysical well-logging activity on the Salton Sea Scientific Drilling Project, Imperial Valley, California

Heat Flow Well Data, Salton Sea Geothermal Field

Geothermal

Heat Flow Well Data, Salton Sea Geothermal Field

Heat Flow Well Data, Salton Sea Geothermal Field

Geothermal

Heat Flow Well Lithology

Geothermal

Geothermal

Geothermal

Ground Water Availability within the Salton Sea Basin: A Final Report

Lawrence Livermore National Laboratory 


\begin{tabular}{|c|c|c|}
\hline Sass, J. H., et al & $\begin{array}{l}\text { Temperature, themal conductivity, heat flow, and radiogenic heat production from } \\
\text { unconsolidated sediments of the Imperial Valley, California }\end{array}$ & Geothermal \\
\hline Ersaghi, Iraj and Abdassah, Doddy & Well log interpretation of certain geothermal fields in the Imperial Valley, California & Geothermal \\
\hline Muramoto, Frank S. and Elders, Wilfred A. & $\begin{array}{l}\text { Correlation of wireline log characteristics with hydrothermal alteration and other } \\
\text { reservoir properties of the Salton Sea and Westmoreland Geothermal Fields, } \\
\text { Imperial Valley, California, USA }\end{array}$ & Geothermal \\
\hline $\begin{array}{l}\text { Newmark, Robin L., Kasameyer, P., W., } \\
\text { and Younker, L. W. }\end{array}$ & Preliminary report on shallow research drilling in the Salton Sea Region & Geothermal \\
\hline Newmark, R., et al & $\begin{array}{l}\text { Research drilling at the Salton Sea Geothermal Field, California: the shallow } \\
\text { thermal gradient project }\end{array}$ & Geothermal \\
\hline Younker, Leland W. et al & $\begin{array}{l}\text { Geological, geophysical, and thermal characteristics of the Salton Sea geothermal } \\
\text { field, California }\end{array}$ & Geothermal \\
\hline Lee, Tien-Chang and Cohen, Lewis H. & $\begin{array}{l}\text { Onshore and offshore measurements of temperature gradients in the Salton Sea } \\
\text { Geothermal Area, California }\end{array}$ & Geothermal \\
\hline Layton, D. and Ermak, D. & $\begin{array}{l}\text { A description of Imperial Valley, California for the assessment of impacts of } \\
\text { geothermal energy development }\end{array}$ & Geothermal \\
\hline Layton, D. & Environment, health, socioeconomics and environmental control technology & Geothermal \\
\hline Bourcier, W., et al & Developing a process for commercial silica production from Salton Sea brines & Geothermal \\
\hline Jarpe, S.P., et al & Seismic monitoring of a flow test in the Salton Sea geothermal field & Geothermal \\
\hline Kasameyer, P. et al & $\begin{array}{l}\text { Development and application of a hydrothemal model for the Salton Sea geothermal } \\
\text { field, CA }\end{array}$ & Geothermal \\
\hline Massonnet, D., et al & $\begin{array}{l}\text { Land subsidence caused by the East Mesa geothermal field, California, observed } \\
\text { using SAR interferometry }\end{array}$ & Geothermal \\
\hline Morse, J.G. and Stone, R. & Evaluation of reservoir properties in a portion of the Salton Sea geothermal field & Geothermal \\
\hline Sass, J. and S. Priest & Bulletin, v. 31, p. 183-187 & Geothermal \\
\hline $\begin{array}{l}\text { Glowacka, E., J.J. Gonzalez, F.A. Nava, F. } \\
\text { Farfan, G. Diaz de Cossio }\end{array}$ & Monitoring surface deformation in the Mexicali Valley, B.C., Mexico & Geothermal \\
\hline $\begin{array}{l}\text { Truesdell, A., A. Manon, L. Quijano, T. } \\
\text { Coplen, M. Lippman }\end{array}$ & $\begin{array}{l}\text { Boiling and condensation processes in the Cerro Prieto Beta reservoir under } \\
\text { exploitation }\end{array}$ & Geothermal \\
\hline Hunter, C.C. & Low-temperature hydrothermal fluids in the Imperial Valley & Geothermal \\
\hline Setmire, J.G. & Water-quality conditions in the New River, Imperial County, California & Groundwater Resource Reports \\
\hline Hely, A.G. and Peck, E.L. & Precipitation, runoff and water loss in the lower Colorado River - Salton Sea area & Groundwater Resource Reports \\
\hline $\begin{array}{l}\text { Bedinger, M.S.; Langer, W.H.; Moyle, } \\
\text { W.R., Jr. }\end{array}$ & $\begin{array}{l}\text { Maps showing ground-water units and withdrawal, Basin and Range Province, } \\
\text { Southern California (PDF text only) }\end{array}$ & Groundwater Resource Reports \\
\hline
\end{tabular}

Ground Water Availability within the Salton Sea Basin: A Final Report Lawrence Livermore National Laboratory 


\begin{tabular}{|c|c|c|}
\hline $\begin{array}{l}\text { Thompson, T.H.; Nuter, J.; Moyle, W.R. Jr.; } \\
\text { Woolfenden, L.R. }\end{array}$ & $\begin{array}{l}\text { Maps showing distribution of dissolved solids and dominant chemical type in } \\
\text { groundwater, Basin and Range Province, Southern California (text only PDF) }\end{array}$ & Groundwater Resource Reports \\
\hline Loeltz, O.J.; Leake, S.A. & $\begin{array}{l}\text { A method for estimating ground-water return flow to the lower Colorado River in } \\
\text { the Yuma area, Arizona and California }\end{array}$ & Groundwater Resource Reports \\
\hline $\begin{array}{l}\text { Langer, W.H., Moyle, W.R., Jr., } \\
\text { Woolfenden, L.R., Mulvihil, D.A. }\end{array}$ & $\begin{array}{l}\text { Maps showing ground-water levels, springs, and depth to ground water, Basin and } \\
\text { Range Province, Southern California (text only PDF) }\end{array}$ & Groundwater Resource Reports \\
\hline Harshbarger and Associates & $\begin{array}{l}\text { Overview report of hydrology and water development; Colorado Delta United States } \\
\text { and Mexico }\end{array}$ & Groundwater Resource Reports \\
\hline Harshbarger and Associates & $\begin{array}{l}\text { Overview report of hydrology and water development; Colorado Delta United States } \\
\text { and Mexico }\end{array}$ & Groundwater Resource Reports \\
\hline Harshbarger and Associates & $\begin{array}{l}\text { Overview report of hydrology and water development; Colorado Delta United States } \\
\text { and Mexico }\end{array}$ & Groundwater Resource Reports \\
\hline Imperial Irrigation District Design Unit & East Mesa Water Conservation Recovery Wells, Preliminary Report & Groundwater Resource Reports \\
\hline LeRoy Crandall and Associates & $\begin{array}{l}\text { Phase I Hydrogeologic investigation feasibility of recovering ground water in the } \\
\text { East Mesa area, Imperial County, California }\end{array}$ & Groundwater Resource Reports \\
\hline LeRoy Crandall and Associates & $\begin{array}{l}\text { Phase I Hydrogeologic investigation feasibility of recovering ground water in the } \\
\text { East Mesa area, Imperial County, California }\end{array}$ & Groundwater Resource Reports \\
\hline U.S. Bureau of Reclamation & $\begin{array}{l}\text { Colorado River water underground storage and recovery study, Imperial County, } \\
\text { California }\end{array}$ & Groundwater Resource Reports \\
\hline U.S. Bureau of Reclamation & $\begin{array}{l}\text { Colorado River water underground storage and recovery study, Imperial County, } \\
\text { California }\end{array}$ & Groundwater Resource Reports \\
\hline U.S .Bureau of Reclamation & $\begin{array}{l}\text { East Highline Canal seepage and system improvement study, Imperial Irrigation } \\
\text { District, California }\end{array}$ & Groundwater Resource Reports \\
\hline U.S .Bureau of Reclamation & $\begin{array}{l}\text { East Highline Canal seepage and system improvement study, Imperial Irrigation } \\
\text { District, California }\end{array}$ & Groundwater Resource Reports \\
\hline California EPA, RWQCB & Staff report: Water quality issues in the Salton Sea Transboundary Watershed & Groundwater Resource Reports \\
\hline $\begin{array}{l}\text { Redlinger, J., Matuska, P., Burnett, P., and } \\
\text { Doebbler, K. }\end{array}$ & $\begin{array}{l}\text { Colorado River Recharge Study (Preliminary Draft), Recharge Demonstration } \\
\text { Interim Technical Report, Imperial County, CA }\end{array}$ & Groundwater Resource Reports \\
\hline $\begin{array}{l}\text { Redlinger, J., Matuska, P., Burnett, P., and } \\
\text { Doebbler, K. }\end{array}$ & $\begin{array}{l}\text { Colorado River Recharge Study (Preliminary Draft), Recharge Demonstration } \\
\text { Interim Technical Report, Imperial County, CA }\end{array}$ & Groundwater Resource Reports \\
\hline $\begin{array}{l}\text { Rockwell, G.L., Anderson, S.W. and } \\
\text { Agajanian, J. }\end{array}$ & $\begin{array}{l}\text { Water Resources Data - California, Water Year 1999; Vol. } 1 \text { - Southern Great Basin } \\
\text { from Mexican Border to Mono Lake Basin and Pacific Slope Basins from Tijuana } \\
\text { River to Santa Maria River }\end{array}$ & Groundwater Resource Reports \\
\hline
\end{tabular}

Ground Water Availability within the Salton Sea Basin: A Final Report Lawrence Livermore National Laboratory 
Anderson, S.W., Agajanian, J. and Rockwell, G.L.

Agajanian, J., Rockwell, G.L, Anderson, S.W., and Pope, G.I.

Rockwell, G.I,. Pope, G.L.,. Agajanian, J., and Caldwell, L.A.

Pope, G.L,. Agajanian, J. Caldwell, L.A., and Rockwell, G.L.

Roggensack, K. and Lopez, D.A.

Hills, A.F.

Johnson, W.D, Jr

Jenness, J.E. and Lopez, D.A.

Owen-Joyce, S.J., Wilson, R.P., Carpenter,

M.C., and Fink, J.B.,

Wilson, R.P., and Owen-Joyce, S.J.,

Wilson, R.P., and Owen-Joyce, S.J.,

Morrison, J., Postel, S.L., Gleick, P.H.

McDondald, C.C. and Loeltz, O.J.

Hardt, W. F. and James, J.

Ballag, A.P., Jr. and Moyle, W.R., Jr.

Bader, J.S.; Moyle, W.R., Jr

San Diego County Water Authority
Water Resources Data - California, Water Year 2000; Vol. 1 - Southern Great Basin from Mexican Border to Mono Lake Basin and Pacific Slope Basins from Tijuana River to Santa Maria River

Water Resources Data - California, Water Year 2001; Vol. 1 - Southern Great Basin from Mexican Border to Mono Lake Basin and Pacific Slope Basins from Tijuana River to Santa Maria River

Water Resources Data - California, Water Year 2002; Vol. 1 - Southern Great Basin from Mexican Border to Mono Lake Basin and Pacific Slope Basins from Tijuana River to Santa Maria River

Water Resources Data - California, Water Year 2003; Vol. 1 - Southern Great Basin from Mexican Border to Mono Lake Basin and Pacific Slope Basins from Tijuana River to Santa Maria River

Map showing outcrops of basaltic rocks of early Quaternary and Tertiary age, Basin and Range Province, Southern California (text only)

Map showing outcrops of granitic rocks and silicic, shallow intrusive rocks, basin and range province, Southern California (text only)

Map showing outcrops of thick, dominantly argillaceous sedimentary and metasedimentary rocks, basin and range province, Southern California (text only)

Map showing outcrops of pre-quaternary ash-flow tuffs, basin and range province, Southern California (text only)

Method to identify wells that yield water that will be replaced by water from the Colorado River downstream from Laguna Dam in Arizona and California

Determining the source of water pumped from wells along the lower Colorado River

Method to identify wells that yield water that will be replaced by Colorado River water in Arizona, California, Nevada, and Utah

The sustainable use of water in the Lower Colorado River Basin

Groundwater Resource Reports

Groundwater Resource Reports

Groundwater Resource Reports

Groundwater Resource Reports

Groundwater Resource Reports

Groundwater Resource Reports

Groundwater Resource Reports

Groundwater Resource Reports

Groundwater Resource Reports

Groundwater Resource Reports

Groundwater Resource Reports

Water Resources of Lower Colorado River-Salton Sea Area as of 1971, Summary Report

Selected data on water wells, geothermal wells, and oil tests in Imperial Valley, California

Groundwater Resource Reports

Groundwater Resource Reports

Water resources and geology of the Los Coyotes Indian Reservation and vicinity, San Diego County, California

Data on water wells and springs in Morongo Valley and vicinity, San Bernardino and Riverside Counties, California Final Draft 2005 Urban Water Management Plan

Groundwater Resource Reports

Groundwater Resource Reports

Groundwater Resource Reports Groundwater Resource Reports

Ground Water Availability within the Salton Sea Basin: A Final Report Lawrence Livermore National Laboratory 
California Department of Water Resources

California Department of Water Resources

California Department of Water Resources

Montgomery Watson Inc.

California Department of Water Resources California Department of Water Resources

Nishikawa, T., J.A. Izbicki, J.A. Hevisi,

C.L. Stamos, P. Martin

Izbicki, J.A. and P. Martin

Mitten, H.T., G.C.Lines, C. Berenbrock, T.J.Durbin

Bloyd, R.M., Jr.

\section{SWRCB}

Imperial Irrigation District

Imperial Irrigation District

IID, MWD, CVWD

The Pacific Institute

SWRCB

U.S. 105th Congress

U.S. and Mexico

U.S. and Mexico

\section{U.S. Congress}

Secretary of the Interior, Gale A. Norton
California's Groundwater: Bulletin 118 Coachella Valley Groundwater Basin, Desert Hot Springs Sub basin

California's Groundwater: Bulletin 118 Coachella Valley Groundwater Basin, Indio Sub basin

California's Groundwater: Bulletin 118 Coachella Valley Groundwater Basin,

Mission Creek Sub basin

Imperial County Groundwater Study, Final Report

Water facts: Numbering water wells in California

Water facts: Yield of a water supply well

Evaluation of geohydrologic framework, recharge estimates, and ground-water flow of the Joshua Tree area,

San Bernardino County, California

Use of isotope data to evaluate recharge and geologic controls on the movement of ground water in Las Posas Valley, Ventura County, California

Water resources of Borrego Valley and vicinity, California: Phase 2 - development of a groundwater flow model

Underground storage of imported water in the San Gorgonio Pass area, Southern California

Revised Order WRO 2002-0013

CEQA findings and Statement of overriding considerations for Imperial Irrigation

District water conservation and transfer project FOR IMPERIAL IRRIGATION DISTRICT WATER CONSERVATION AND TRANSFER PROJECT

Resolution No. 9-2003

Quantification Settlement Agreement and Related Agreements and Documents

Comments on the Salton Sea Restoration Project and the Salton Sea Restoration Project Draft Environmental Impact Statement Environmental Impact Report Colorado River Basin Salinity Control Act, Title II Salton Sea Reclamation Act, Public Law 105-372

Agreement between the U.S. and Mexico on cooperation for the protection and improvement of the environment in the border area

Annex II (Agreement of Cooperation between U.S. and Mexico for protection and improvement of the environment in the border area)

Colorado River Compact, $1922 \quad$ Legal Documents

Colorado River Water Delivery Agreement: Federal Quantification Settlement Legal Documents

Groundwater Resource Reports

Groundwater Resource Reports

Groundwater Resource Reports

Groundwater Resource Reports

Groundwater Resource Reports

Groundwater Resource Reports

Groundwater Resource Reports

Groundwater Resource Reports

Groundwater Resource Reports

Groundwater Resource Reports

Legal Documents

Legal Documents

Legal Documents

Legal Documents

Legal Documents

Legal Documents

Legal Documents

Legal Documents

Legal Documents

Ground Water Availability within the Salton Sea Basin: A Final Report

Lawrence Livermore National Laboratory 


\begin{tabular}{|c|c|c|}
\hline & Agreement & \\
\hline Coachella Valley Water District & Water directors certify EIS, EIR for Coachella Canal Project & Legal Documents \\
\hline EPA & Coachella Canal Lining Project, Coachella and Imperial Counties, California & Legal Documents \\
\hline Condes de la Torre & Support by the U.S. Geological Survey for adjudications, compacts, and treaties & Legal Documents \\
\hline Wright, R. & Tijuana River Watershed Atlas & Mexico \\
\hline Maganda, $\mathrm{C}$. & $\begin{array}{l}\text { Collateral Damage: How the San Diego-Imperial Valley agreement affects the } \\
\text { Mexican site of the border }\end{array}$ & Mexico \\
\hline U.S. Bureau of Reclamation & $\begin{array}{l}\text { Hydrologic effects provoked in Mexican Territory by the recovery of infiltrated } \\
\text { water in the "All American Canal" in California, United States of America }\end{array}$ & Mexico \\
\hline $\begin{array}{l}\text { National Water Commission of the Republic } \\
\text { of Mexico }\end{array}$ & Analysis by Republic of Mexico & Mexico \\
\hline Castro-Ruiz, J.L. and Sanches-Munuia, V. & The lining of the All American Canal: Effects on Mexico & Mexico \\
\hline Skrivan, J.A. & $\begin{array}{l}\text { Digital-Model evalutation of the ground-water resources in the Ocotillo-Coyote } \\
\text { Wells Basin, Imperial County, California }\end{array}$ & Modelling \\
\hline Geonomics, Inc. & $\begin{array}{l}\text { An assessment report on baseline geotechnical data for environmental monitoring of } \\
\text { geothermal development in four geothermal areas in the Western United States }\end{array}$ & Modelling \\
\hline $\begin{array}{l}\text { Hulen, J.B., Kaspereit, D., Norton, D.L., } \\
\text { Osborn, W., Pulka, F.S. }\end{array}$ & $\begin{array}{l}\text { Refined conceptual modeling and a new resource estimate for the Salton Sea } \\
\text { Geothermal Field, Imperial Valley, California }\end{array}$ & Modelling \\
\hline Kasameyer, P. W., et al & $\begin{array}{l}\text { Development and application of a hydrothermal model for the Salton Sea } \\
\text { Geothermal Field, California }\end{array}$ & Modelling \\
\hline Tyley, S. J. & $\begin{array}{l}\text { Analog Model Study of the ground-water basin of the Upper Coachella Valley, } \\
\text { California }\end{array}$ & Modelling \\
\hline Patten, E.P., Jr. & Analog simulation of the ground-water system, Yuma, Arizona & Modelling \\
\hline Patten, E.P., Jr. & Analog simulation of the ground-water system, Yuma, Arizona & Modelling \\
\hline Riney, T. D.; Pritchett, J. W.; Rice, L. F & $\begin{array}{l}\text { Integrated model of the shallow and deep hydrothermal systems in the East Mesa } \\
\text { area, Imperial Valley, California }\end{array}$ & Modelling \\
\hline Reichard, E. G, and Meadows, J.K. & $\begin{array}{l}\text { Evaluation of a ground-water flow and transport model of the upper Coachella } \\
\text { Valley, California }\end{array}$ & Modelling \\
\hline von Allworden, B. K., et al & $\begin{array}{l}\text { Lower Colorado River Accounting System (LCRAS) computer program and } \\
\text { documentation }\end{array}$ & Modelling \\
\hline Hill, B. M. & $\begin{array}{l}\text { Hydrogeology, numberical model and scenario simulations of the Yuma area } \\
\text { groundwater flow model, Arizona, California, and Mexico }\end{array}$ & Modelling \\
\hline Anderson, T.W. and Freethey, G.W. & $\begin{array}{l}\text { Simulation of ground-water flow in alluvial basins in south-central Arizona and } \\
\text { parts of adjacent states }\end{array}$ & Modelling \\
\hline
\end{tabular}

Ground Water Availability within the Salton Sea Basin: A Final Report Lawrence Livermore National Laboratory 


\begin{tabular}{|c|c|c|}
\hline Buckles, J.E., K. Kashiwase, T. Krantz & $\begin{array}{l}\text { Reconstruction of prehistoric Lake Cahuilla in the Salton Sea Basin using GIS and } \\
\text { GPS }\end{array}$ & Modelling \\
\hline Brown, John S. & $\begin{array}{l}\text { The Salton Sea Region, California: A Geographic, Geologic and Hydrologic } \\
\text { Reconnaissance with a Guide to Desert Watering Places }\end{array}$ & Regional Geology \\
\hline Thompson, D.G. & $\begin{array}{l}\text { The Mojave Desert region, California, a geographic, geologic, and hydrologic } \\
\text { reconnaissance }\end{array}$ & Regional Geology \\
\hline Diblee, T.W., Jr. & Geology of the Imperial Valley region, in Geology of southern California & Regional Geology \\
\hline Diblee, T.W., Jr. & Geology of the Imperial Valley region, in Geology of southern California & Regional Geology \\
\hline Diblee, T.W., Jr. & Geology of the Imperial Valley region, in Geology of southern California & Regional Geology \\
\hline Diblee, T.W., Jr. & Geology of the Imperial Valley region, in Geology of southern California & Regional Geology \\
\hline Diblee, T.W., Jr. & Geology of the Imperial Valley region, in Geology of southern California & Regional Geology \\
\hline Diblee, T.W., Jr. & Geology of the Imperial Valley region, in Geology of southern California & Regional Geology \\
\hline Diblee, T.W., Jr. & Geology of the Imperial Valley region, in Geology of southern California & Regional Geology \\
\hline Jahns, R.H. & $\begin{array}{l}\text { Investigations and problems of southern California Geology in Geology of southern } \\
\text { California }\end{array}$ & Regional Geology \\
\hline Jahns, R.H. & $\begin{array}{l}\text { Investigations and problems of southern California Geology in Geology of southern } \\
\text { California }\end{array}$ & Regional Geology \\
\hline Jahns, R.H. & $\begin{array}{l}\text { Investigations and problems of southern California Geology in Geology of southern } \\
\text { California }\end{array}$ & Regional Geology \\
\hline Jahns, R.H. & $\begin{array}{l}\text { Investigations and problems of southern California Geology in Geology of southern } \\
\text { California }\end{array}$ & Regional Geology \\
\hline Hart, E.W. and others & $\begin{array}{l}\text { Summary Report: Fault Evaluation Program. 1986-1987, Mojave Desert and other } \\
\text { areas (Imperial, Kern, Los Angeles, Riverside and San Bernardino Counties), } \\
\text { California }\end{array}$ & Regional Geology \\
\hline Babcock, E.A. & Geology of the northeast margin of the Salton Trough, Salton Sea, California & Regional Geology \\
\hline Fuis, G.S., et al & Seismic-refraction studies of the Imperial Valley region, California & Regional Geology \\
\hline Larsen, S. and Reilinger, R. & $\begin{array}{l}\text { Age constraints for the present fault configuration in the Imperial Valley, California: } \\
\text { Evidence for northwestward propogation of the Gulf of California rift system }\end{array}$ & Regional Geology \\
\hline Miller. D.M. & Geology and seismicity of the Salton Basin & Regional Geology \\
\hline URS & Preliminary in-sea geotechnical investigation, Salton Sea Restoration Project & Regional Geology \\
\hline Hill, D.P., et al & Earthquakes, active faults, and geothermal areas in the Imperial Valley, California & Regional Geology \\
\hline Sharp, R.V., et al & Seismic profiles of Salton Sea, Southern California, cruise of 1969 & Regional Geology \\
\hline Jahns, R.H. & Geology of the Peninsular Range Province, southern California and Baja California & Regional Geology \\
\hline Jahns, R.H. & Geology of the Peninsular Range Province, southern California and Baja California & Regional Geology \\
\hline
\end{tabular}

Ground Water Availability within the Salton Sea Basin: A Final Report Lawrence Livermore National Laboratory 


\begin{tabular}{|c|c|c|}
\hline Jahns, R.H. & Geology of the Peninsular Range Province, southern California and Baja California & Regional Geology \\
\hline Jahns, R.H. & Geology of the Peninsular Range Province, southern California and Baja California & Regional Geology \\
\hline Jahns, R.H. & Geology of the Peninsular Range Province, southern California and Baja California & Regional Geology \\
\hline Dorsey, R. & Stratigraphy, tectonics, and basin evolution in the Anza-Borrega Desert Region & Regional Geology \\
\hline Loeltz, O.J. and others & Geohydrologic Reconnaissance of the Imperial Valley, California & Regional Hydrology \\
\hline Loeltz, O.J. and others & Geohydrologic Reconnaissance of the Imperial Valley, California & Regional Hydrology \\
\hline Tetra Tech, Inc. & $\begin{array}{l}\text { Final Report, A Study on Seepage and Subsurface Inflows to Salton Sea and } \\
\text { Adjacent Wetlands }\end{array}$ & Regional Hydrology \\
\hline $\begin{array}{l}\text { Hely, A.G., Hughes, G.H. and Ireland, } \\
\text { Burdge }\end{array}$ & Hydrologic regimen of Salton Sea, California & Regional Hydrology \\
\hline Mendenhall, W.C. & Ground waters of the Indio region, California, with a sketch of the Colorado Desert & Regional Hydrology \\
\hline Mendenhall, W.C. & Ground waters of the Indio region, California, with a sketch of the Colorado Desert & Regional Hydrology \\
\hline Mendenhall, W.C. & Ground waters of the Indio region, California, with a sketch of the Colorado Desert & Regional Hydrology \\
\hline Mendenhall, W.C. & Ground waters of the Indio region, California, with a sketch of the Colorado Desert & Regional Hydrology \\
\hline California Department of Water Resources & California's Groundwater: Bulletin 118 Amos Valley Groundwater Basin & Regional Hydrology \\
\hline California Department of Water Resources & California's Groundwater: Bulletin 118 Chocolate Valley Groundwater Basin & Regional Hydrology \\
\hline California Department of Water Resources & California's Groundwater: Bulletin 118 Ocotillo-Clark Valley Groundwater Basin & Regional Hydrology \\
\hline California Department of Water Resources & California's Groundwater: Bulletin 118 Arroyo Seco Valley Groundwater Basins & Regional Hydrology \\
\hline California Department of Water Resources & California's Groundwater: Bulletin 118 Coyote Wells Valley Groundwater Basin & Regional Hydrology \\
\hline California Department of Water Resources & California's Groundwater: Bulletin 118 Orocopia Valley Groundwater Basin & Regional Hydrology \\
\hline California Department of Water Resources & California's Groundwater: Bulletin 118 Borrego Valley Groundwater Basin & Regional Hydrology \\
\hline California Department of Water Resources & California's Groundwater: Bulletin 118 Update 2003 & Regional Hydrology \\
\hline California Department of Water Resources & California's Groundwater: Bulletin 118 East Salton Sea Groundwater Basin & Regional Hydrology \\
\hline California Department of Water Resources & California's Groundwater: Bulletin 118 Imperial Valley Groundwater Basin & Regional Hydrology \\
\hline California Department of Water Resources & California's Groundwater: Bulletin 118 Vallecito-Carrizo Valley Groundwater Basin & Regional Hydrology \\
\hline California Department of Water Resources & California's Groundwater: Bulletin 118 West Salton Sea Groundwater Basin & Regional Hydrology \\
\hline $\begin{array}{l}\text { Olmsted, F.H., Loeltz, O.J., and Irelan, } \\
\text { Burdge }\end{array}$ & Geohydrology of the Yuma area, Arizona and California & Regional Hydrology \\
\hline $\begin{array}{l}\text { Olmsted, F.H., Loeltz, O.J., and Irelan, } \\
\text { Burdge }\end{array}$ & Geohydrology of the Yuma area, Arizona and California & Regional Hydrology \\
\hline Robertson, F.N. & $\begin{array}{l}\text { Geochemistry of ground water in alluvial basins of Arizona and adjacent parts of } \\
\text { Nevada, New Mexico, and California }\end{array}$ & Regional Hydrology \\
\hline
\end{tabular}

\section{2}

Ground Water Availability within the Salton Sea Basin: A Final Report Lawrence Livermore National Laboratory 
Michel, R.L. and Schroeder, R.A

Moyle, W.R. Jr.

Moyle, W.R., et al

Clapp, W.B.

Clapp, W.B.

Moyle, W.R. Jr.

SWRCB

California Department of Water Resources

Dutcher, L.C. and Garrett, A.A.

Dutcher, L.C. and Garrett, A.A.

Smith, Peroni \& Fox, Planning Consultants, Inc.

Imperial County Planning/Building

Department

Schroeder, R.A., J.G. Setmire, J.N.

Densmore

U.S. Bureau of Reclamation

Huges, G.H.

U.S. Bureau of Reclamation

\begin{tabular}{l}
\hline Bourne, J.K, Jr. \\
\hline Mendenhall, W.C. \\
\hline Mendenhall, W.C. \\
\hline ESRI \\
\hline Brown, J.S. \\
\hline Weghorst, P.A.
\end{tabular}

Use of long-term records from the Colorado River to determine timescales for hydrologic processes associated with irrigation in the Imperial Valley, California

Water resources of Borrego Valley and vicinity, California: Phase 1 - Definition of geologic and hydrologic characteristics of basin

Southern California alluvial basins regional aquifer-systems analysis: a bibliography

The surface water supply of California, 1906, with a section on groundwater levels in southern California

The surface water supply of California, 1906, with a section on groundwater levels in southern California

Ground-water-level monitoring for earthquake prediction: a progress report based on data collected in southern California, 1976-79

Water Quality Control Plan, Colorado River Basin-Region 7

California's Groundwater: Bulletin 118 Coachella Valley Groundwater Basin, San

Gorgonio Pass Sub basin

Geologic and hydrologic features of the San Bernardino area, California - with

special reference to underflow across the San Jacinto fault

Geologic and hydrologic features of the San Bernardino area, California - with special reference to underflow across the San Jacinto fault

City of Coachella, General Plan EIR, Surface Hydrology section 3.3

Water Element, County of Imperial General Plan

Use of stable isotopes, tritium, soluble salts, and redox-sensitive elements to distinguish ground water from irrigation water in the Salton Sea basin Evaporation data

Analysis of techniques used to measure evaporation from Salton Sea, California Colorado River Basin salinity control projects, Title I, Coachella Canal unit, California, ground-water hydrology of the Coachella Canal area

Eccentric Salton Sea

Some desert watering places in southeastern California and southwestern Nevada

Some desert watering places in southeastern California and southwestern Nevada

Salton Sea California's Everglades

Routes to desert watering places in the Salton Sea Region, California Salton Sea Accounting Model
Regional Hydrology

Regional Hydrology

Regional Hydrology

Regional Hydrology

Regional Hydrology

Regional Hydrology

Regional Hydrology

Regional Hydrology

Regional Hydrology

Regional Hydrology

Regional Hydrology

Regional Hydrology

Regional Hydrology

Regional Hydrology

Regional Hydrology

Regional Hydrology

Salton Sea - General Interest

Salton Sea - General Interest

Salton Sea - General Interest

Salton Sea - General Interest

Salton Sea - General Interest Salton Sea - General Interest

133

Ground Water Availability within the Salton Sea Basin: A Final Report

Lawrence Livermore National Laboratory 


\begin{tabular}{|c|c|c|}
\hline unk & Sea Views, Salton Sea restoration proposals & Salton Sea - General Interest \\
\hline Carpelan, L.H. & History of the Salton Sea & Salton Sea - General Interest \\
\hline ESRI & Salton Sea hydrology & Salton Sea - General Interest \\
\hline Suzanne Michel, Ed. & US-Mexican Border Environment, Binational Water Management Planning & US-Mexico Border Issues \\
\hline Barnum & Selenium Presentation & Water Quality \\
\hline Ireland, B. & Salinity of surface water in the lower Colorado River-Salton Sea area & Water Quality \\
\hline Setmire, J.G. & $\begin{array}{l}\text { Water quality in the New River from Calexico to the Salton Sea, Imperial County, } \\
\text { California }\end{array}$ & Water Quality \\
\hline Gruenberg, P. & New River Pollution in Mexico, a historical overview & Water Quality \\
\hline Salton Sea Authority & Selenium and the Salton Sea & Water Quality \\
\hline U.S. Department of the Interior & Quality of Water Colorado River Basin & Water Quality \\
\hline $\begin{array}{l}\text { LeBlanc, L. A., Schroeder, R.A., Orlando, } \\
\text { J.L., and Kuivila, K.M. }\end{array}$ & $\begin{array}{l}\text { Occurrence, Distribution and Transport of Pesticides, Trace Elements and Selected } \\
\text { Inorganic Constituents into the Salton Sea Basin, California, 2001-2002 }\end{array}$ & Water Quality \\
\hline Williams, W.D. & $\begin{array}{l}\text { Environmental threats to salt lakes and the likely status of inland saline ecosystems } \\
\text { in } 2025\end{array}$ & Water Quality \\
\hline Redlands Institute & $\begin{array}{l}\text { Salton Sea Watershed Water Quality Monitoring Program, Inventory and } \\
\text { Assessment }\end{array}$ & Water Quality \\
\hline $\begin{array}{l}\text { Apodaca, L.E., Stephens, V.C., Driver, } \\
\text { N.E. }\end{array}$ & What Affects Water Quality In the Upper Colorado River Basin? & Water Quality \\
\hline $\begin{array}{l}\text { Belitz, K. Dubrovsky, N.M., Burow, K., } \\
\text { Jurgens, B. and Johnson, T. }\end{array}$ & $\begin{array}{l}\text { Framework for a Ground-Water Quality Monitoring and Assessment Program for } \\
\text { California }\end{array}$ & Water Quality \\
\hline $\begin{array}{l}\text { Crepeau, K.L., Kuivila, K.M., Bergamaschi, } \\
\text { B. }\end{array}$ & Dissolved Pesticides in the Alamo River and the Salton Sea, California, 1996-97 & Water Quality \\
\hline Williams, W.D. & Anthropogenic salinization of inland waters & Water Quality \\
\hline Rhoades, J.D. & $\begin{array}{l}\text { Estimation of volumes of tailwater and deep percolation in the IID service area } \\
\text { using chloride mass balance relationships }\end{array}$ & Water Quality \\
\hline LeBlanc, L.A., J.L.Orlando, K.M. Kuivila & $\begin{array}{l}\text { Pesticide concentrations in water and in suspended and bottom sediments in the New } \\
\text { and Alamo Rivers, Salton Sea watershed, California, April } 2003\end{array}$ & Water Quality \\
\hline ESRI & Salton Sea watershed water quality monitoring program, inventory and assessment & Water Quality \\
\hline Hely, A.G. & Lower Colorado River water supply - its magnitude and distribution & Water Supply Issues \\
\hline Loeltz, O.J. and Leake, S.A. & $\begin{array}{l}\text { Relation between proposed developments of water resources and seepage from the } \\
\text { All American Canal, eastern Imperial Valley, California }\end{array}$ & Water Supply Issues \\
\hline SWRCB & Revised Order WRO 2002-0016 & Water Supply Issues \\
\hline Owen-Joyce, S.J. & Accounting system for water use by vegetation in the lower Colorado River valley & Water Supply Issues \\
\hline
\end{tabular}

Ground Water Availability within the Salton Sea Basin: A Final Report Lawrence Livermore National Laboratory 


\begin{tabular}{|c|c|c|}
\hline Owen-Joyce, S.J., and Raymond, L.H. & $\begin{array}{l}\text { An accounting system for water and consumptive use along the lower Colorado } \\
\text { River, Hoover Dam to Mexico }\end{array}$ & Water Supply Issues \\
\hline Pontius, D. & Colorado River Basin Study, Final Report & Water Supply Issues \\
\hline Weghorst, P.A. & QSA baseline (with QSA) modeling at the Salton Sea (slide presentation) & Water Supply Issues \\
\hline Owen-Joyce, S.J. & $\begin{array}{l}\text { Identifying wells downstream from Laguna Dam that yield Water that will be } \\
\text { replaced by water from the Colorado River, Arizona and California }\end{array}$ & Water Supply Issues \\
\hline McDonald, C.C and Hughes, G.H. & $\begin{array}{l}\text { Studies of consumptive use of water by phreatophytes and hydrophytes near Yuma, } \\
\text { Arizona }\end{array}$ & Water Supply Issues \\
\hline Pulido-Velasques, M.A. & Conjunctive use opportunities in Southern California & Water Supply Issues \\
\hline Pulido-Velazques, M.A., et al & Economic values for conjunctive use and water banking in southern California & Water Supply Issues \\
\hline $\begin{array}{l}\text { Montgomery Watson and Water Education } \\
\text { Foundation }\end{array}$ & Groundwater and surface water in southern California - a guide to conjunctive use & Water Supply Issues \\
\hline Imperial Irrigation District & Water conservation and transfer project - Final EIR/EIS, Table of Contents & Water Supply Issues \\
\hline Coachella Valley Water District & Coachella Valley Final Water Management Plan & Water Supply Issues \\
\hline Scott, J.L. & Estimates of tailwater volumes in the Imperial Irrigation District & Water Supply Issues \\
\hline Borrego Water District & Borrego Water District groundwater management plan & Water Supply Issues \\
\hline
\end{tabular}





\section{Appendix C: \\ Table Descriptions in Current Salton Sea Water Resource Database}

\begin{tabular}{|c|c|}
\hline Table Name & Description \\
\hline basement_depth_Dutcher & Depth to basement in Imperial Valley (feet bgl) \\
\hline CALIF_ARIZONA & State polygons \\
\hline CITIES_OVER10K_CLIP & CA and AZ cities over 10,000 population with demographics \\
\hline county_sel & So. California and Western Arizona counties \\
\hline DAMS & Name, location, physical props. dams along the Colo. R. \\
\hline faults_Dutcher & Faults published in USGS Professional Paper of region \\
\hline Federal_Owned_Land & Name, owner, agency, state, for all of US \\
\hline Wells_geothermal & Geothermal wells use, type, name, location, construction data \\
\hline GWBASIN_SS & DWR names, location \\
\hline HIGHWAY & Secondary roads, US \\
\hline hydroline_US & Streams: type, name, state for all US \\
\hline INTERSTATE_SEL & Interstate for Salton Sea region, type, name \\
\hline IsotopeData & Tritium, $\mathrm{O} 16 / \mathrm{O} 18$, and deuterium/protium within region \\
\hline lcr_land_new & Lower Colorado River land ownership \\
\hline mexico_community & Country boundary with municipality areas \\
\hline mexico_cities & Mexico cities: name, state, population, capital or not \\
\hline mexico_contours & Very gross topographic contours (BC) \\
\hline mexico_hydro_1 & Mexican streams - entire country \\
\hline mexico_hydro_p & Mexican surface water bodies \\
\hline mexico_roads & Mexican roads \\
\hline mexico_SS_watershed & Mexican portion of Salton Sea watershed \\
\hline mexico_states & States of Mexico, name, sq mi. \\
\hline mexico_urban_areas & Mexico city areas (not point only) \\
\hline parks_sel_US & Salton Sea region public parks, names \\
\hline QUATERNARY_FAULTS_USGS & $\begin{array}{l}\text { USGS Quaternary faults of So. CA, name, slip, rate, dip } \\
\text { direction }\end{array}$ \\
\hline SFC_WATER_BODY & Surface water bodies in So. CA. and western AZ (name, type) \\
\hline SS_ZERO_MSL & Topographic contour of zero mean sea level in region \\
\hline SURFACE_POINTS_INBASIN & Clip of surface water stations within Salton Sea Watershed \\
\hline SWATH_WELLS & Clip of proposed area for groundwater sampling \\
\hline tblAGENCY & Address, phone and website for data information sources \\
\hline tblAGENCY_DIVISION & Division of agency for data sources \\
\hline tblCANAL & $\begin{array}{l}\text { Physical properties and historical information of canals in the } \\
\text { basin }\end{array}$ \\
\hline
\end{tabular}




\begin{tabular}{ll}
\hline \hline tblCASIL_SEL & Well information from the CASIL data portal \\
tblCHEMISTRY_DATA & $\begin{array}{l}\text { Analytical data and physical properties of soil, gw and surface } \\
\text { water }\end{array}$ \\
\hline tblCONTACT & Contact information of person who dispenses and maintains data \\
\hline tblGW_BASIN & Recharge, sed depth, storage capacity, avg. well depth and yield \\
\hline tblGW_ELEV & Well groundwater information (depth, date measured) \\
\hline tblGWATER_BASIN & GW basins of So. California (polygons and DWR names) \\
\hline tblHydroUnit & Stratigraphy and Fm name of Unit \\
\hline tblO_Isotope & Radionuclide tracer parameters, Imperial Valley \\
tblRESERVOIR & $\begin{array}{l}\text { Physical properies and historical information of reservoirs along } \\
\text { Colo. R }\end{array}$ \\
\hline tblSFC_WATER_STATION & $\begin{array}{l}\text { Surface water stations in Imperial, San Diego and San } \\
\text { Bernardino Co's. }\end{array}$ \\
tblTownshipRange_AZ_CA & $\begin{array}{l}\text { Grid of US Public Lands Survey Townships and Ranges in CA } \\
\text { and AZ }\end{array}$ \\
tblWELL_CONSTR & $\begin{array}{l}\text { Summary of CA Dept. of Water Resources Well Driller's } \\
\text { Reports (Imperial Co.) }\end{array}$ \\
\hline tblWells & $\begin{array}{l}\text { Parent table of wells and sfc.station information (location [L,L; } \\
\text { TRS], name) }\end{array}$ \\
WATERSHED_ALL & Salton Sea Watersheds (DWR nested areas and IDs) \\
\hline \hline
\end{tabular}




\section{Appendix D: \\ Data and Data Sources Reflected in the Salton Sea Database}

\begin{tabular}{|c|c|}
\hline Data Source & Description \\
\hline $\begin{array}{l}\text { Bureau of Reclamation, Lower Colorado } \\
\text { Dams Facilities Office }\end{array}$ & $\begin{array}{l}\text { Historical surface water quantity and quality data from guages along } \\
\text { the Colorado River dam system }\end{array}$ \\
\hline Bureau of Reclamation, Yuma Area Office & Colorado River dam water quality and flow data \\
\hline $\begin{array}{l}\text { California Department of Forestry Fire and } \\
\text { Resource Assessment Program }\end{array}$ & $\begin{array}{l}\text { California Interagency Watershed Map of } 1999 \text { (CalWater 2.2.1), } \\
\text { nested watersheds }\end{array}$ \\
\hline $\begin{array}{l}\text { California Department of Water Resources, } \\
\text { Division of Planning and Local Assistance, } \\
\text { Southern District (DPLA) }\end{array}$ & $\begin{array}{l}\text { Historical data of surface and groundwater quality data; information } \\
\text { about canals and lining projects; Water Well Driller's reports }\end{array}$ \\
\hline $\begin{array}{l}\text { California Integrated Waste Management } \\
\text { Board (CIWMB) }\end{array}$ & Disposal facility information (location, type, status) \\
\hline $\begin{array}{l}\text { California Spatial Data Information Center } \\
\text { (CASIL) }\end{array}$ & $\begin{array}{l}\text { Well data for the state of California; geographic spatial data (county, } \\
\text { state, Public Land Survey [township, range, section], hydrography, } \\
\text { hydrologic basins, administrative district boundaries; city data }\end{array}$ \\
\hline $\begin{array}{l}\text { California Department of Water Resources, } \\
\text { California Data Exchange Center (CDEC) }\end{array}$ & Historical flow and water quality for Imperial Dam \\
\hline Coachella Valley Water District & CVWD district boundaries \\
\hline $\begin{array}{l}\text { Department of Conservation, California } \\
\text { Geological Survey }\end{array}$ & Quaternary and younger fault data \\
\hline $\begin{array}{l}\text { Department of Conservation, Division of } \\
\text { Oil, Gas and Geothermal }\end{array}$ & Oil, gas, and geothermal well information \\
\hline $\begin{array}{l}\text { Environmental Protection Agency (EPA), } \\
\text { Water Quality Data, STORET Database }\end{array}$ & Historical data of surface and groundwater quality data \\
\hline $\begin{array}{l}\text { Environmental Systems Research Institute, } \\
\text { Inc. (ESRI) }\end{array}$ & $\begin{array}{l}\text { Geographic spatial data (city, county, state, transportation network, } \\
\text { streams, water bodies) }\end{array}$ \\
\hline Imperial Irrigation District (IID) & Service area map \\
\hline $\begin{array}{l}\text { Instituto National de Estradistica Geografia } \\
\text { e Informatica }\end{array}$ & Mexico DEMs, other data \\
\hline $\begin{array}{l}\text { Metropolitan Water District of Southern } \\
\text { California }\end{array}$ & Service area map \\
\hline US Geological Survey & $\begin{array}{l}\text { US quaternary faults and associated folds with relative movement, } \\
\text { earthquake record, displacement; DEMs }\end{array}$ \\
\hline $\begin{array}{l}\text { US Geological Survey, National Water } \\
\text { Information System (NWIS) }\end{array}$ & Historical data of surface and groundwater quality and flow data \\
\hline
\end{tabular}





\section{Appendix E: \\ Other Tracers used for Groundwater Dating and Source Identification}

There are a number of other stable and radioactive compounds that may be employed to age-date groundwater or determine its source or flow pathway. They may be of used, for example, if water samples are "tritium dead" - that is, if the age appears to be greater than 50 years. They may also be used to assess to what extent specific kinds of water-rock interaction shave occurred along a flow pathway, or as a means to detect co-contaminant signatures from "bomb pulse" atmospheric releases or other contemporary atmospheric components (such as volatile organic compounds). For example:

- Radiocarbon: ${ }^{14} \mathrm{C}$ can be used to identify order of magnitude estimate of subsurface residence time for $>1000$ to $40,000 \mathrm{yrs}$;

- Radiogenic Helium: ${ }^{4} \mathrm{He}_{\text {rad }}$ can be used to identify order of magnitude estimate of subsurface residence time for $>100$ to 100,000 yrs;

- Trace level organic compounds: Methyl Tertiary Butyl Ether (MtBE) and other volatile organic compounds (VOCs), for example, can be used to confirm the presence of recent recharge;

- Major anions and cations: $\mathrm{Na}, \mathrm{K}, \mathrm{Mg}, \mathrm{Ca}, \mathrm{Cl}, \mathrm{NO}_{3}$, and $\mathrm{SO}_{4}$, for example, can be used to identify a water source and water-rock interactions along flow pathways

- Trace elements: Se, As, and other trace metals, for example, can be used to identify a water source and water-rock interactions along flow pathways

- Other long-lived cosmogenic isotopes: ${ }^{36} \mathrm{Cl}$ and ${ }^{129} \mathrm{I}$ can be used to identify order of magnitude estimate of subsurface residence time for up to millions of years, as well as water-rock interactions along flow pathways. ${ }^{36} \mathrm{Cl}$ related to atomic weapons testing in the atmosphere can also be identified and used to determine recent recharge histories.

Table E. 1 provides a summery of the role of isotopes and tracers commonly used in groundwater investigations (including those summarized in Sections 6.2 and 6.3), special handling requirements associated with sample collection, as well as an estimate of the typical analytical measurement costs for one sample (including sampling vessel, but not technician time).

Moran and Halliwell (2003), Moran et al. (2002a,b; 2003; 2005a,b), and Tompson et al. (2006), among others, have described the used of isotopes for dating groundwater, inferring flow pathways, and estimating its vulnerability to contamination. Tompson et al $(1999,2006)$ have also described the use of radioisotopes to develop calibration targets in computer simulation models of groundwater flow. Within the context of the Salton Sea Basin, such tracers may be used, for example, to:

- Date old to very old waters expected at great depths, but possibly present in some shallower locations if there are circulation pathways 
Table E.1. Groundwater tracers commonly used in investigations and typical analytical cost per sample. Sample costs include sampling vessel but not the time expense of technician collection.

\begin{tabular}{|c|c|c|c|c|}
\hline Tracer & $\begin{array}{l}\text { Alternate } \\
\text { name(s) }\end{array}$ & $\begin{array}{l}\text { Utility in groundwater } \\
\text { investigations }\end{array}$ & $\begin{array}{c}\text { Cost } \\
\text { per } \\
\text { sample }\end{array}$ & $\begin{array}{l}\text { Special } \\
\text { handling } \\
\text { requirements }\end{array}$ \\
\hline $\begin{array}{r}\text { Stable isotopes } \\
\text { of water }\end{array}$ & $\begin{array}{l}\delta^{18} \mathrm{O} \text { and } \delta \mathrm{D} ; \\
{ }^{18} \mathrm{O} /{ }^{16} \mathrm{O} \\
\mathrm{D} / \mathrm{H}\end{array}$ & $\begin{array}{l}\text { Identify recharge water source, } \\
\text { degree of evaporation }\end{array}$ & $\$ 220$ & $\begin{array}{l}30 \mathrm{ml} \text { air-tight } \\
\text { glass container }\end{array}$ \\
\hline Tritium & ${ }^{3} \mathrm{H}$ & $\begin{array}{l}\text { Identify presence or absence of } \\
\text { post-modern water (recharged } \\
<50 \text { years ago) }\end{array}$ & $\$ 550$ & $\begin{array}{l}\text { 1-L air-tight glass } \\
\text { container }\end{array}$ \\
\hline $\begin{array}{l}\text { Tritium- } \\
\text { Helium }\end{array}$ & ${ }^{3} \mathrm{H}-{ }^{3} \mathrm{He}$ & $\begin{array}{l}\text { Determine groundwater age date } \\
\text { (time since recharge), up to } 50 \\
\text { years before present }\end{array}$ & $\$ 1,460$ & $\begin{array}{l}\text { Copper tube with } \\
\text { s.s. pinch clamps; } \\
\text { not exposed to } \\
\text { atmosphere }\end{array}$ \\
\hline $\begin{array}{r}\text { Radiogenic } \\
\text { Helium }\end{array}$ & ${ }^{4} \mathrm{He}_{\mathrm{rad}}$ & $\begin{array}{l}\text { Identify order of magnitude } \\
\text { estimate of subsurface residence } \\
\text { time for }>100 \text { to } 100,000 \mathrm{yrs}\end{array}$ & $\$ 910$ & $\begin{array}{l}\text { Copper tube with } \\
\text { s.s. pinch clamps } \\
\text { not exposed to } \\
\text { atmosphere }\end{array}$ \\
\hline Radiocarbon & ${ }^{14} \mathrm{C}$ & $\begin{array}{l}\text { Identify order of magnitude } \\
\text { estimate of subsurface residence } \\
\text { time for }>1000 \text { to } 40,000 \text { yrs }\end{array}$ & $\$ 650$ & $\begin{array}{l}250 \mathrm{ml} \text { amber } \\
\text { glass with } \\
\text { septum; poisoned }\end{array}$ \\
\hline $\begin{array}{r}\text { Trace level } \\
\text { organic } \\
\text { compounds }\end{array}$ & $\begin{array}{l}\text { e.g., MtBE \& } \\
\text { other VOCs }\end{array}$ & $\begin{array}{l}\text { Confirm presence of recent } \\
\text { recharge }\end{array}$ & $\$ 550$ & $\begin{array}{l}40 \mathrm{ml} \text { VOA vials, } \\
\text { shipped on ice } \\
\text { analyzed within } \\
14 \text { days }\end{array}$ \\
\hline $\begin{array}{r}\text { Major anions } \\
\text { and cations }\end{array}$ & $\begin{array}{l}\text { e.g., } \mathrm{Na}, \mathrm{K} \\
\mathrm{Mg}, \mathrm{Ca}, \mathrm{Cl} \\
\mathrm{NO}_{3}, \mathrm{SO}_{4} \text {, etc. }\end{array}$ & $\begin{array}{l}\text { Identify water source and water- } \\
\text { rock interaction }\end{array}$ & $\$ 200$ & Filter, ship cold \\
\hline Trace elements & $\begin{array}{l}\text { e.g., } \mathrm{Se}, \mathrm{As}, \\
\text { other trace } \\
\text { metals }\end{array}$ & $\begin{array}{l}\text { Identify water source and water- } \\
\text { rock interaction }\end{array}$ & $\$ 400$ & $\begin{array}{l}\text { Acidify, clean } \\
\text { techniques }\end{array}$ \\
\hline $\begin{array}{r}\text { Other } \\
\text { long-lived } \\
\text { cosmogenic } \\
\text { isotopes }\end{array}$ & e.g., ${ }^{36} \mathrm{Cl},{ }^{129} \mathrm{I}$ & $\begin{array}{l}\text { Identify order of magnitude } \\
\text { estimate of subsurface residence } \\
\text { time for up to millions of yrs, } \\
\text { water-rock interaction }\end{array}$ & $\$ 650$ & $\begin{array}{l}1 \text { to } 5 \mathrm{~L} \text { in hard } \\
\text { plastic container }\end{array}$ \\
\hline
\end{tabular}


- Identify the presence of younger waters, including trace atmospheric components representative of the past 50 to 100 years, at significant depths,

- Separate bodies of groundwater attributable to agricultural use, canal infiltration, natural recharge, or ancient seawater; or otherwise

- Confirm hypotheses relating to the separation of the shallow and deeper groundwater systems in the basin. 



\section{Appendix F:}

\section{Water Level Data for Model Initialization}

Table F1: Database-derived water level data used to create a regional groundwater elevation map for 2003 in support of the Groundwater Model, Section 7.

\begin{tabular}{|c|c|c|c|c|c|}
\hline \multirow{2}{*}{ Location ID } & \multicolumn{2}{|c|}{ Coordinates $[\mathrm{m}]^{1}$} & \multirow{2}{*}{$\begin{array}{c}\text { Measured } \\
\text { Groundwater } \\
\text { Elevation [m] }\end{array}$} & \multirow{2}{*}{$\begin{array}{c}\text { Surface } \\
\text { Elevation } \\
{[\mathbf{m}]^{2}}\end{array}$} & \multirow{2}{*}{$\begin{array}{c}\text { Applied } \\
\text { Groundwater } \\
\text { Elevation }[\mathrm{m}]\end{array}$} \\
\hline & East & North & & & \\
\hline 002S001E29B001S & 509,289 & $3,759,656$ & 976.5 & 1015.9 & 976.5 \\
\hline 002S001E29C001S & 508,365 & $3,759,347$ & 1011.4 & 1068.8 & 1011.4 \\
\hline 002S001E29K002S & 508,982 & $3,758,178$ & 949.0 & 1004.7 & 949.0 \\
\hline 002S001E29P001S & 508,777 & $3,758,054$ & 952.0 & 998.9 & 952.0 \\
\hline 002S001W35J001S & 504,877 & $3,756,850$ & 677.2 & 845.8 & 677.2 \\
\hline $002 \mathrm{~S} 001 \mathrm{~W} 35 \mathrm{~J} 002 \mathrm{~S}$ & 504,877 & $3,756,850$ & 677.4 & 845.8 & 677.4 \\
\hline 002S001W35J003S & 504,877 & $3,756,850$ & 677.8 & 845.8 & 677.8 \\
\hline $003 \mathrm{~S} 001 \mathrm{E} 03 \mathrm{C} 002 \mathrm{~S}$ & 512,090 & $3,755,686$ & 728.5 & 776.8 & 728.5 \\
\hline $003 \mathrm{~S} 001 \mathrm{E} 04 \mathrm{~A} 001 \mathrm{~S}$ & 511,448 & $3,756,086$ & 776.5 & 812.5 & 776.5 \\
\hline 003S001E06N001S & 506,675 & $3,754,511$ & 660.2 & 778.2 & 660.2 \\
\hline 003S001E08M001S & 508,653 & $3,753,434$ & 595.5 & 747.9 & 595.5 \\
\hline 003S001E10N001S & 511,606 & $3,753,191$ & 536.7 & 701.3 & 536.7 \\
\hline 003S001E14A001S & 514,482 & $3,752,795$ & 513.2 & 633.5 & 513.2 \\
\hline 003S001E18A001S & 508,165 & $3,752,849$ & 645.1 & 735.4 & 645.1 \\
\hline 003S001E18B001S & 507,601 & $3,752,848$ & 639.3 & 749.1 & 639.3 \\
\hline 003S001E18C001S & 507,036 & $3,752,848$ & 645.7 & 753.9 & 645.7 \\
\hline 003S001E18D001S & 506,650 & $3,752,848$ & 653.5 & 757.5 & 653.5 \\
\hline 003S001E18L001S & 507,036 & $3,751,924$ & 635.8 & 734.4 & 635.8 \\
\hline $003 \mathrm{~S} 001 \mathrm{E} 19 \mathrm{~B} 001 \mathrm{~S}$ & 507,602 & $3,751,247$ & 658.2 & 732.4 & 658.2 \\
\hline $003 \mathrm{~S} 001 \mathrm{~W} 12 \mathrm{~L} 001 \mathrm{~S}$ & 505,726 & $3,753,309$ & 733.6 & 774.5 & 733.6 \\
\hline $003 \mathrm{~S} 002 \mathrm{E} 07 \mathrm{~K} 001 \mathrm{~S}$ & 517,306 & $3,753,446$ & 463.8 & 596.0 & 463.8 \\
\hline 003S002E09E001S & 519,590 & $3,753,728$ & 394.4 & 605.0 & 394.4 \\
\hline 003S003E07D001S & 525,930 & $3,754,482$ & 370.4 & 500.9 & 370.4 \\
\hline 003S003E07M001S & 526,010 & $3,753,435$ & 365.1 & 448.5 & 365.1 \\
\hline 003S003E08A001S & 528,780 & $3,754,521$ & 371.1 & 460.5 & 371.1 \\
\hline 003S003E08M001S & 527,935 & $3,753,441$ & 355.8 & 410.3 & 355.8 \\
\hline 003S004E20F001S & 537,832 & $3,750,580$ & 155.5 & 270.8 & 155.5 \\
\hline 003S004E20F002S & 537,832 & $3,750,580$ & 154.4 & 270.8 & 154.4 \\
\hline 003S004E20F003S & 537,832 & $3,750,580$ & 153.6 & 270.8 & 153.6 \\
\hline
\end{tabular}

142 


\begin{tabular}{|c|c|c|c|c|c|}
\hline 003S004E20J001S & 538,707 & $3,750,306$ & 150.9 & 255.5 & 150.9 \\
\hline 003S004E20J002S & 538,707 & $3,750,306$ & 150.7 & 255.5 & 150.7 \\
\hline 003S004E20J003S & 538,707 & $3,750,306$ & 150.1 & 255.5 & 150.1 \\
\hline 003S004E29F001S & 537,761 & $3,749,224$ & 149.3 & 262.9 & 149.3 \\
\hline 003S004E29R001S & 538,690 & $3,748,212$ & 125.7 & 238.3 & 125.7 \\
\hline 009S009E04M001S & 588,406 & $3,697,722$ & -73.4 & -37.9 & -73.4 \\
\hline 012S009E23D001S & 592,389 & $3,664,496$ & -67.7 & -2.0 & -67.7 \\
\hline 013S018E33A001S & 679,950 & $3,652,590$ & 35.2 & 101.0 & 35.2 \\
\hline $016 \mathrm{~S} 009 \mathrm{E} 24 \mathrm{~B} 001 \mathrm{~S}$ & 594,313 & $3,625,925$ & 87.8 & 124.3 & 87.8 \\
\hline $016 \mathrm{~S} 009 \mathrm{E} 25 \mathrm{M} 002 \mathrm{~S}$ & 593,713 & $3,623,394$ & 82.2 & 138.5 & 82.2 \\
\hline 016S009E35N002S & 592,273 & $3,621,440$ & 95.5 & 192.0 & 95.5 \\
\hline 016S010E32P001S & 597,271 & $3,621,457$ & 76.8 & 128.0 & 76.8 \\
\hline 016S011E27F001S & 610,312 & $3,623,995$ & 7.6 & 29.7 & 7.0 \\
\hline 017S010E11B001S & 600,798 & $3,617,673$ & 61.3 & 153.3 & 61.3 \\
\hline 017S010E11G001S & 600,803 & $3,617,211$ & 61.5 & 153.8 & 61.5 \\
\hline 017S010E11G004S & 600,726 & $3,617,087$ & 63.8 & 154.7 & 63.8 \\
\hline 017S010E11H003S & 601,039 & $3,617,029$ & 61.3 & 151.3 & 61.3 \\
\hline 017S011E16J001S & 607,545 & $3,615,126$ & 56.9 & 93.7 & 55.0 \\
\hline ControlPoint101 & 710,000 & $3,694,605$ & & 325.2 & 50.0 \\
\hline ControlPoint103 & 645,179 & $3,654,191$ & & -40.0 & \\
\hline ControlPoint104 & 669,546 & $3,635,173$ & & 30.9 & \\
\hline ControlPoint105 & 648,745 & $3,613,480$ & & 7.5 & \\
\hline ControlPoint106 & 720,658 & $3,626,555$ & & & \\
\hline ControlPoint109 & 678,461 & $3,590,004$ & & 20.1 & \\
\hline ControlPoint1 10 & 633,590 & $3,571,581$ & & -9.7 & \\
\hline ControlPoint112 & 620,000 & $3,593,000$ & & & -17.0 \\
\hline ControlPoint112 & 630,000 & $3,583,689$ & & & -33.0 \\
\hline ControlPoint112a & 639,634 & $3,661,309$ & & & -62.0 \\
\hline ControlPoint112b & 646,501 & $3,652,860$ & & & -48.0 \\
\hline ControlPoint112c & 652,411 & $3,644,518$ & & & -28.0 \\
\hline ControlPoint1 12d & 665,000 & $3,606,454$ & & & -22.0 \\
\hline ControlPoint113 & 702,123 & $3,563,557$ & & & 1.0 \\
\hline ControlPoint1 14 & 680,893 & $3,590,465$ & & & -4.0 \\
\hline ControlPoint1 15 & 695,281 & $3,684,333$ & & & 30.0 \\
\hline ControlPoint1 16 & 618,100 & $3,623,600$ & 7.6 & 29.7 & -13.0 \\
\hline ControlPoint1 17 & 716,000 & $3,672,800$ & 7.6 & 29.7 & 55.0 \\
\hline ControlPoint1 17 & 716,000 & $3,660,000$ & 7.6 & 29.7 & 52.0 \\
\hline
\end{tabular}

${ }^{1}$ Coordinate system based on Universal Transverse Mercator projection, Zone 11, Clarke 1866/NAD27 ellipsoid

${ }^{2}$ Surface elevations interpolated from digital elevation model (DEM) grid 
